\title{
Final Report - LAW Envelope A and B Glass Formulations Testing to Increase Waste Loading. VSL-06R6900-1
}

Prepared for the U.S. Department of Energy

Assistant Secretary for Environmental Management

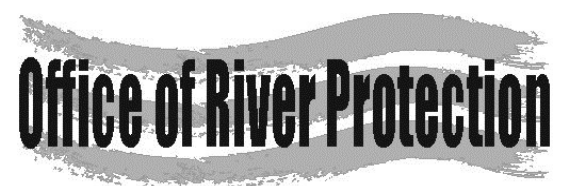

P.O. Box 450

Richland, Washington 99352 
ORP-56322

Revision 0

\section{Final Report - LAW Envelope A and B Glass Formulations Testing to Increase Waste Loading. VSL-06R6900-1}

A. A. Kruger

Department of Energy - Office of River Protection

I. Joseph

The Catholic University of America

I. S. Muller

The Catholic University of America

W. Gong

The Catholic University of America
H. Gan

The Catholic University of America

I. L. Pegg

The Catholic University of America

K. S. Matlack

The Catholic University of America

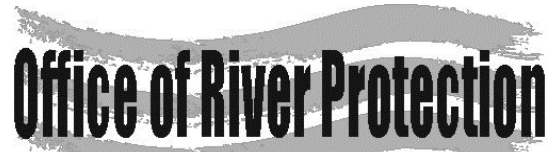

\section{P.O. Box 450}

Richland, Washington 99352

\section{APPROVED}

By Julia Raymer at 8:11 am, Dec 03, 2013 
ORP-56322

Revision 0

TRADEMARK DISCLAIMER

Reference herein to any specific commercial product, process, or service by tradename, trademark, manufacturer, or otherwise, does not necessarily constitute or imply its endorsement, recommendation, or favoring by the United States Government or any agency thereof or its contractors or subcontractors.

This report has been reproduced from the best available copy.

Printed in the United States of America 
VSL-06R6900-1

\title{
Final Report
}

LAW Envelope A and B Glass Formulations Testing to Increase Waste Loading

\author{
prepared by
}
Keith S. Matlack, Weiliang Gong, Isabelle S. Muller, Innocent Joseph, and Ian L. Pegg

\author{
Vitreous State Laboratory \\ The Catholic University of America \\ Washington, DC 20064 \\ for \\ Duratek, Inc. \\ and \\ Department of Energy \\ Office of River Protection
}

January 20, 2006

Rev. 0, 3/23/06 
The Catholic University of America

Vitreous State Laboratory
ORP-56322, Rev. 0

LAW Envelope A and B Glass Formulations Testing to Increase Waste Loading

Final Report, VSL-06R6900-1, Rev. 0
Document Title:

\section{Document Number and Revision:}

Issue Date:

Performing Organization: Vitreous State Laboratory, The Catholic University of

Test Plan:

LAW Glass Formulation Testing to Increase Waste Loading, VSL-05T5900-1, Rev. 0 Increase Waste Loading

VSL-06R6900-1, Rev. 0

$3 / 23 / 06$ America

LAW Envelope A and B Glass Formulations Testing to

This report describes the results of testing specified by the above Test Plan. The work was performed in compliance with the quality assurance requirements specified in the Test Plan. Results required by the Test Plan are reported. The test results and this report have been reviewed for correctness, technical adequacy, completeness, and accuracy.

I.L. Pegg

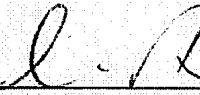

2

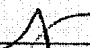
VSL Program Director/Principal Inyestigator

Date: $3 / 23 / 06$

I. Joseph: Amocent losebb Duratek Sub-Contract Manager
Date: $3 / 23 / 06$ 
The Catholic University of America Vitreous State Laboratory
LAW Envelope A and B Glass Formulations Testing to Increase Waste Loading Final Report, VSL-06R6900-1, Rev. 0

\section{TABLE OF CONTENTS}

LIST OF TABLES. 4

LIST OF FIGURES ..6

LIST OF ABBREVIATIONS

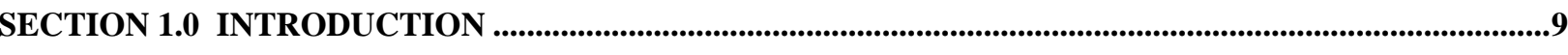

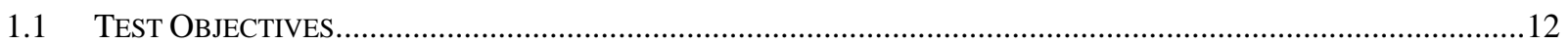

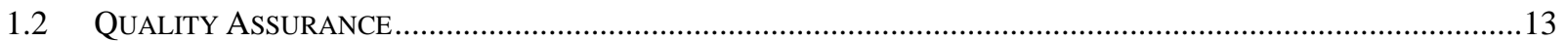

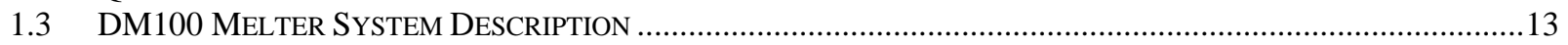

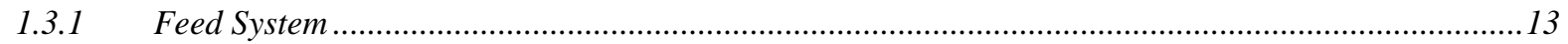

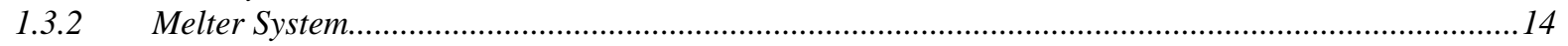

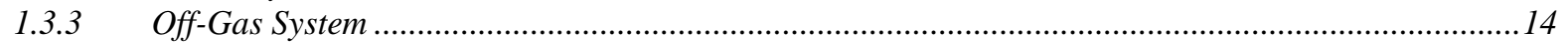

SECTION 2.0 WASTE SIMULANT AND GLASS FORMULATIONS ........................................................15

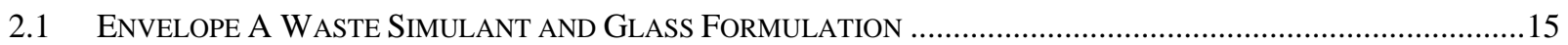

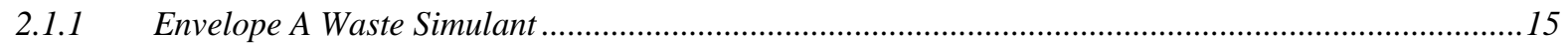

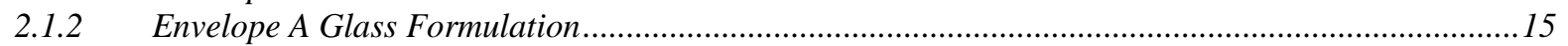

2.2 ENVELOPE B WASTE SimULANT AND GLASS FORMULATION ...........................................................20

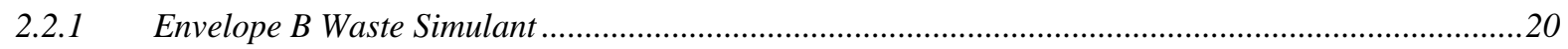

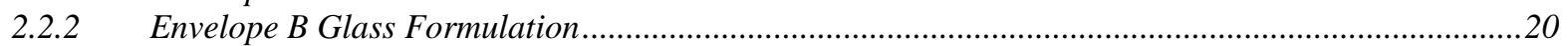

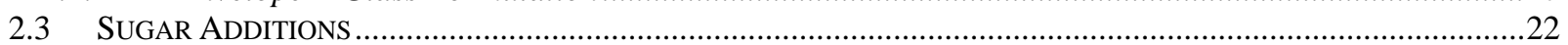

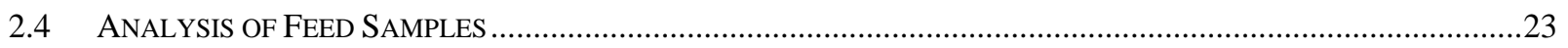

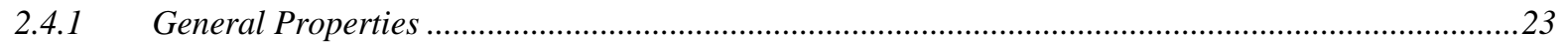

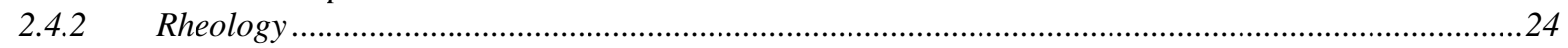

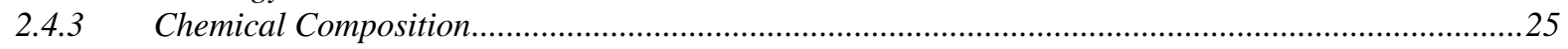

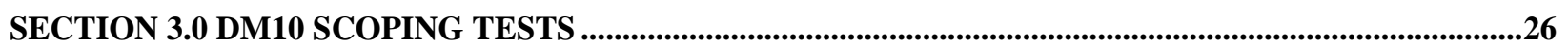

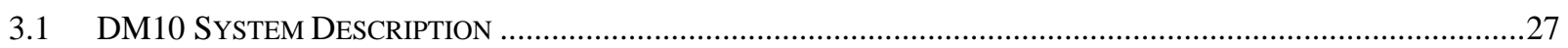

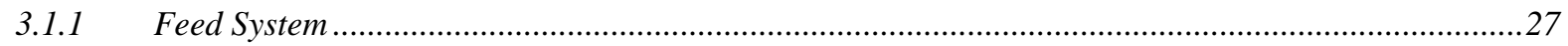

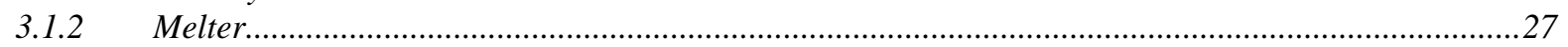

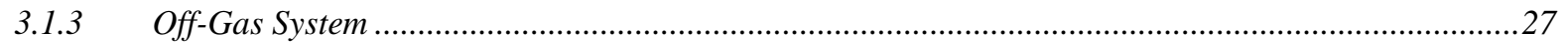

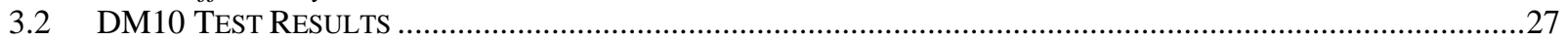

3.3 FEED SULFUR CONCENTRATIONS SELECTED FROM DM10 TESTS ........................................................29

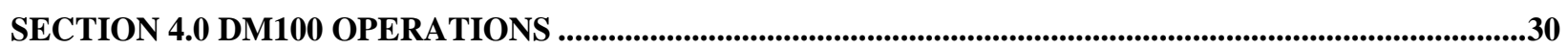

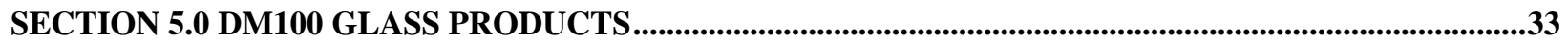

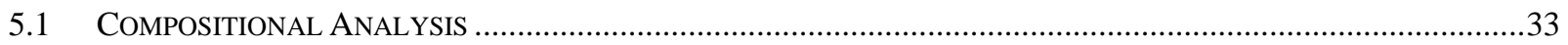

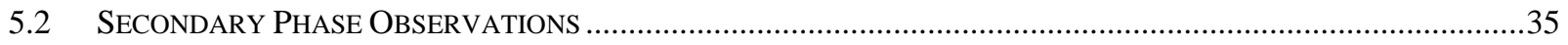

5.3 COMPARISON OF PCT AND VHT OF CRUCIBLE AND MELTER GLASSES....................................................35

5.3.1 Comparison of PCT and VHT of Envelope A Crucible and Melter Glasses......................................35

5.3.2 Comparison of PCT and VHT of Envelope B Crucible and Melter Glasses.......................................36

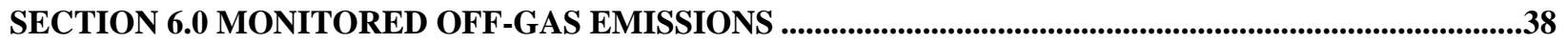

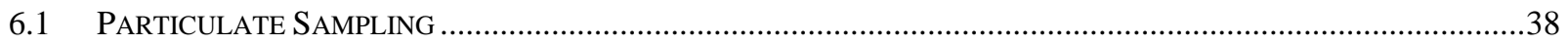

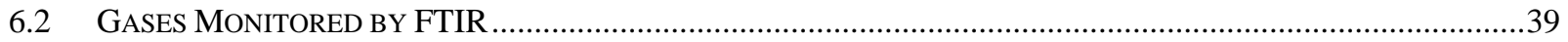

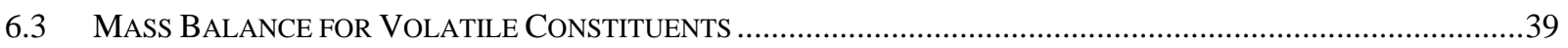

SECTION 7.0 COMPARISON OF TEST RESULS FOR “OLD” AND “NEW” FORMULATIONS ..............41

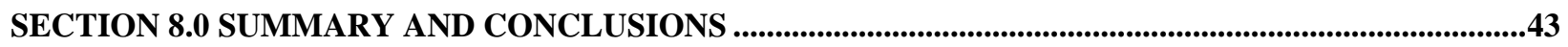

8.1 IMPACT ON LAW PROCESSING RATE AND GLASS VOLUME .............................................................44

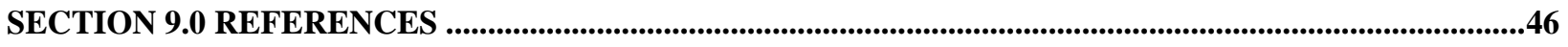


The Catholic University of America Vitreous State Laboratory
LAW Envelope A and B Glass Formulations Testing

to Increase Waste Loading

Final Report, VSL-06R6900-1, Rev. 0

\section{List of Tables}

Table 2.1. LAW Sub-Envelope A1 (AN-105) Waste Simulant Recipe at 8 Molar Sodium.

$\mathrm{T}-1$

Table 2.2. Target and Analyzed Compositions (wt\%) of Seventeen Envelope A Crucible Glasses with $23 \mathrm{wt} \% \mathrm{Na}_{2} \mathrm{O}$ or $30.4 \mathrm{wt} \%$ Waste Loading.

Table 2.3. Target and Analyzed Compositions (wt\%) of Ten Envelope A Crucible Glasses with $25 \mathrm{wt} \% \mathrm{Na}_{2} \mathrm{O}$ or 32.9 wt\% Waste Loading.

Table 2.4. Descriptions of Seventeen As-Melted and Heat Treated Envelope A Crucible Glasses with $23 \mathrm{wt} \% \mathrm{Na}_{2} \mathrm{O}$ or $30.4 \mathrm{wt} \%$ Waste Loading.

Table 2.5. Descriptions of Ten As-Melted and Heat Treated Envelope A Crucible Glasses with $25 \mathrm{wt} \% \mathrm{Na}_{2} \mathrm{O}$ or $32.9 \mathrm{wt} \%$ waste loading.

Table 2.6. Measured Compositions (wt\%) of Twenty Seven New LAW Envelope A Crucible Glasses Remelted with 4 wt\% Excess $\mathrm{SO}_{3}$.

Table 2.7. Results of 7-day PCT (at $90^{\circ} \mathrm{C}$ ) and VHT (at $200^{\circ} \mathrm{C}$ for 24 Days $\left(\mathrm{g} / \mathrm{m}^{2} /\right.$ day)) for Twenty Seven New LAW Envelope A Crucible Glasses.

Table 2.8. Viscosities and Electrical Conductivities of Twenty Seven New LAW Envelope A Crucible Glasses.

Table 2.9. $\quad$ Measured Densities and Glass Transition Temperatures (by Differential Thermal Analysis) of Seventeen New LAW Envelope A Crucible Glasses.

Table 2.10. Results of K-3 Corrosion Testing for Sixteen of the New LAW Envelope A Crucible Glasses.

Table 2.11. Summary of Test Results for Selected Glass Formulation LAWA187 and Comparison to ILAW Requirements.

Table 2.12. Oxide Composition of LAW Envelope A Simulant and Corresponding Glass Composition Used in Melter Tests (wt\%).

Table 2.13. Glass Former Additives for 1 Liter of LAW Envelope A Simulant (8 M Na) and Corresponding Melter Feed Properties.

Table 2.14. $\mathrm{NaOH}$ and $\mathrm{Na}_{2} \mathrm{SO}_{4}$ Additions Required to Obtain $23 \mathrm{wt} \% \mathrm{Na}_{2} \mathrm{O}$ and Various $\mathrm{SO}_{3}$ Concentrations in the LAWA187 Glass Ranging from 0.80 to $1.2 \mathrm{wt} \%$.

Table 2.15. LAW Sub-Envelope B2 Simulant Recipe at 4 Molar Sodium.

Table 2.16. Target and Analyzed Compositions (wt\%) of Nine Envelope B Crucible Glasses.

Table 2.17. Measured Compositions (wt\%) of Nine New LAW Envelope B Crucible Glasses Remelted with $4 \mathrm{wt} \%$ Excess $\mathrm{SO}_{3}$.

Table 2.18. Results of 7-day PCT (at $90^{\circ} \mathrm{C}$ ) and VHT (at $200^{\circ} \mathrm{C}$ for 24 Days (g/m $/$ day)) for Nine New LAW Envelope B Crucible Glasses.

Table 2.19. Viscosities and Electrical Conductivities of Nine New LAW Envelope B Crucible Glasses.

Table 2.20. Measured Densities and Glass Transition Temperatures (by Differential Thermal Analysis) of LAW Envelope B Crucible Glasses.

Table 2.21. Results of K-3 Corrosion Testing for Three of the New LAW Envelope B Crucible Glasses.

Table 2.22. Summary of Test Results for Selected Glass Formulation LAWB99 and Comparison to ILAW Requirements.

Table 2.23. Oxide Composition of LAW Envelope B Simulant and Corresponding Glass Composition Used in Melter Tests (wt\%).

Table 2.24. Glass Former Additives for 1 Liter of LAW Envelope B Simulant (4 M Na) and Corresponding Melter Feed Properties.

Table 2.25. $\mathrm{NaOH}$ and $\mathrm{Na}_{2} \mathrm{SO}_{4}$ Additions Required to Obtain $10 \mathrm{wt} \% \mathrm{Na}_{2} \mathrm{O}$ and Various $\mathrm{SO}_{3}$ Concentrations in the LAWB99 Glass Ranging from 1.0 to $1.6 \mathrm{wt} \%$. 
The Catholic University of America Vitreous State Laboratory
LAW Envelope A and B Glass Formulations Testing

to Increase Waste Loading

Final Report, VSL-06R6900-1, Rev. 0

Table 2.28. $\quad$ XRF Analyzed Compositions for LAWB Melter Feed Samples (wt\%). $\quad$ T-34

Table 2.29. $\quad$ XRF Analyzed Compositions for LAWA Melter Feed Samples (wt\%). $\quad$ T-35

Table 2.30. XRF and DCP Analyzed Compositions for Melter Feed Samples (wt\%). T-36

Table 3.1. Summary of LAWB DM10 Test Conditions and Results. $\quad$ T-37

Table 3.2. $\quad$ Summary of LAWA DM10 Test Conditions and Results. $\quad$ T-38

Table 3.3. Listing of LAWB DM10 Glasses Discharged, Masses, and Measured Sulfur and Iodine Contents.

T-39

Table 3.4. Listing of LAWA DM10 Glasses Discharged, Masses, and Measured Sulfur and Iodine Contents.

\begin{tabular}{llr} 
Table 3.5. & Dip samples and Presence of Sulfate Layer During DM10 Melter Tests. & T-43 \\
Table 4.1. & Summary of DM100 Test Conditions and Results. & T-44 \\
\hline
\end{tabular}

Table 4.2. Summary of Measured DM100 Parameters. $\quad$ T-45

Table 5.1. Listing of LAWB DM100 Glasses Discharged, Masses, and Analysis Performed. $\quad$ T-46

Table 5.2. $\quad$ Listing of LAWA DM100 Glasses Discharged, Masses, and Analysis Performed. $\quad$ T-49

Table 5.3. $\quad$ XRF Analyzed Composition for LAWB DM100 Discharged Glass Samples (wt\%). $\quad$ T-53

Table 5.4. $\quad$ XRF Analyzed Composition for LAWA DM100 Discharged Glass Samples (wt\%). $\quad$ T-58

Table 5.5. $\quad$ Comparison of XRF and DCP Analysis of Melter Glass Samples (wt\%). T-63

Table 5.6. $\quad$ Dip samples and Presence of Sulfate Layer During DM100 Melter Tests. T-64

Table 5.7. Results of PCT (7-days at $90^{\circ} \mathrm{C}$ ) and VHT (at $200^{\circ} \mathrm{C}$ for 24 Days (g/m²/day))

for LAW Envelope A Crucible and DM100 Melter Glasses.

T-65

Table 5.8. Comparison of XRF Analyzed Composition for Melter Glass Sample Before and After Canister Cooling Heat Treatment (wt\%).

Table 5.9. Results of PCT (7-days at $90^{\circ} \mathrm{C}$ ) and VHT (at $200^{\circ} \mathrm{C}$ for 24 Days $\left(\mathrm{g} / \mathrm{m}^{2} /\right.$ day)) for LAW Envelope B Crucible and DM100 Melter Glasses.

Table 6.1. $\quad$ Results from LAW B Melter Off-Gas Emission Samples. $\quad$ T-68

Table 6.2. $\quad$ Results from LAW A Melter Off-Gas Emission Samples. $\quad$ T-69

Table 6.3. Average Concentration (ppmv) of Selected Species in Off-Gas

$\begin{array}{lr}\text { Measured by FTIR Spectroscopy during DM100 Tests. } & \text { T-70 }\end{array}$

Table 6.4. $\quad$ Average NOx Fluxes in Off-Gas Measured by FTIR Spectroscopy. $\quad$ T-71

$\begin{array}{lll}\text { Table 6.5. } & \text { Mass Balances for Sulfur, Iodine, and Chlorine During Select DM100 } \\ & \text { Tests with LAW Simulants (\% of Feed). }\end{array}$

Table 7.1. Compositions and Properties of New and Old LAW Envelope A Glasses $\quad$ T-73

Table 7.2. $\quad$ Compositions and Properties of New and Old LAW Envelope B Glasses $\quad$ T-74

Table 8.1. Tank-by-Tank $\mathrm{Na}_{2} \mathrm{O}$ and $\mathrm{SO}_{3}$ Loadings in Glass and Mass of Glass Product Based on

(i) The Current WTP Baseline LAW Glass Composition Correlation [57] and

(ii) The Enhanced Formulations Developed in the Present Work.

$\mathrm{T}-75$ 
The Catholic University of America Vitreous State Laboratory
LAW Envelope A and B Glass Formulations Testing

to Increase Waste Loading

Final Report, VSL-06R6900-1, Rev. 0

\section{List of Figures}

Figure 1.1.

Figure 1.2(a).

Figure 1.2(b).

Figure 1.2(c).

Figure 2.1.

Figure 2.2.

Figure 2.3.

Figure 2.4.

Figure 2.5.

Figure 2.6.

Figure 2.7.

Figure 2.8 .

Figure 2.9.

Figure 2.10.

Figure 2.11.

Figure 2.12.

Figure 2.13.

Figure 2.14.

Figure 2.15.

Figure 3.1.a.

Figure 3.1.b.

Figure 3.2.a.

Figure 3.2.b.

Figure 3.3.

Figure 3.4.

Figure 4.1.a.

Figure 4.1.b.

Figure 4.2.a.

Figure 4.2.b.

Figure 4.3.a.

Figure 4.3.b.

Figure 4.4.a. Figure 4.4.b. Figure 4.5.a. Figure 4.5.b. Figure 5.1.
Schematic diagram of DuraMelter 100-WV vitrification system.

F-1

Cross-section through the DM100-WV melter-Plan View.

$\mathrm{F}-2$

Cross-section through the DM100-WV melter-Section AA.

Cross-section through the DM100-WV melter-Section CC.

Results of $\mathrm{SO}_{2} / \mathrm{O}_{2}$ gas bubbling tests on the new LAW Envelope A

glass LAWA187, the previous ORP Envelope A glass LAWA161, and

a WTP baseline Envelope A glass composition LAWA44.

F-5

Measured sulfate solubility by $\mathrm{SO}_{2} / \mathrm{O}_{2}$ gas bubbling and by remelting

with excess $\mathrm{SO}_{3}$ for twenty seven new LAW Envelope A crucible glasses.

VHT results for twenty seven new LAW Envelope A crucible glasses.

Normalized PCT responses for twenty seven new LAW Envelope A

crucible glasses.

K3 Corrosion results for sixteen new LAW Envelope A crucible glasses

and three old LAW formulations.

Centerline canister cooling curve used for heat treatment of

LAWA187CCC, LAWB99CCC, and Envelope A melter glass EWV89CCC.

Optical and SEM images of sample LAWA187CCC.

F-3

F-4

EDS analysis of sodalite crystals in a sample of LAWA187CCC.

Results of $\mathrm{SO}_{2} / \mathrm{O}_{2}$ gas bubbling tests on the new LAW Envelope B

glass LAWB99, previous ORP Envelope A glass LAWA161, and ORP

Envelope C glass LAWC100.

F-13

Measured sulfate solubility by $\mathrm{SO}_{2} / \mathrm{O}_{2}$ gas bubbling and by remelting with

excess $\mathrm{SO}_{3}$ for nine new LAW Envelope $\mathrm{B}$ crucible glasses.

F-14

F-15

F-16

Normalized PCT responses for nine new LAW Envelope B crucible glasses.

F-6

F-7

F-8

F-9

F-10

F-11

F-12

K3 Corrosion results for three new LAW Envelope B crucible glasses,

LAWA187 and two old WTP LAW formulations.

F-17

F-18

Comparison of measured feed rheology with proposed WTP bounds

(bounds from WTP-RPT-075, Rev. 0, Feb. 2003).

F-19

F-20

F-21

XRF analysis of sulfur in DM10 LAWA product glasses.

F-22

F-23

XRF analysis of iodine in DM10 LAWA product glasses.

F-24

Secondary sulfur phases on the glass pool surface after LAWA DM10

F-25

Test A1B.

F-26

F-27

F-28

F-29

Glass temperatures for the DM100 LAW Envelope A tests.

Plenum temperatures and electrode power for the DM100 LAW

Envelope B tests.

F-30

Plenum temperatures and electrode power for the DM100 LAW

Envelope A tests.

F-31

F-32

F-33

F-34

$\begin{array}{ll}\text { Glass pool bubbling rate during DM100 LAW Envelope A tests. } & \text { F-35 }\end{array}$

XRF analysis of $\mathrm{Na}_{2} \mathrm{O}$ and $\mathrm{SiO}_{2}$ in LAW B DM100 product glasses.

F-36 
The Catholic University of America Vitreous State Laboratory
LAW Envelope A and B Glass Formulations Testing

to Increase Waste Loading

Final Report, VSL-06R6900-1, Rev. 0

Figure 5.2. $\quad$ XRF analysis of $\mathrm{Na}_{2} \mathrm{O}$ and $\mathrm{SiO}_{2}$ in LAW A DM100 product glasses. $\quad$ F-37

Figure 5.3. $\quad$ XRF analysis of select major oxides in LAW B DM100 product glasses. $\quad$ F-38

$\begin{array}{lll}\text { Figure 5.4. } & \text { XRF analysis of select major oxides in LAW A DM100 product glasses. } & \text { F-39 }\end{array}$

$\begin{array}{lll}\text { Figure 5.5. } & \text { XRF analysis of oxides in product glasses decreasing in concentration } \\ \text { during LAW B DM100 tests. } & \text { F-40 }\end{array}$

Figure 5.6. $\quad$ XRF analysis of oxides increasing in concentration during LAW A DM100 tests. $\quad$ F-41

$\begin{array}{lll}\text { Figure 5.7. } & \text { XRF analysis of iodine in LAW B DM100 product glasses. } & \text { F-42 }\end{array}$

$\begin{array}{lll}\text { Figure 5.8. } & \text { XRF analysis of iodine in LAW A DM100 product glasses. } & \text { F-43 }\end{array}$

$\begin{array}{lll}\text { Figure 5.9. } & \text { XRF analysis of sulfur in LAW B DM100 product glasses. } & \text { F-44 }\end{array}$

$\begin{array}{lll}\text { Figure 5.10. } & \text { XRF analysis of sulfur in LAW A DM100 product glasses. } & \text { F-45 }\end{array}$

$\begin{array}{lll}\text { Figure 6.1.a. } & \text { Nitrogen oxide concentrations in off-gas from FTIR for the DM100 } & \text { F-46 }\end{array}$

$\begin{array}{lll}\text { Figure 6.1.b. } & \text { Nitrogen oxide concentrations in off-gas from FTIR for the DM100 LAW } \\ \text { Envelope A tests. }\end{array}$

Figure 6.2.a. $\quad$ CO concentrations in off-gas from FTIR for the DM100 LAW Envelope B tests. $\quad$ F-48

Figure 6.2.b. $\quad$ CO concentrations in off-gas from FTIR for the DM100 LAW Envelope A tests. $\quad$ F-49

Figure 6.3.a. $\quad \mathrm{NH}_{3}$ concentrations in off-gas from FTIR for the DM100 LAW Envelope B tests. $\quad$ F-50

Figure 6.3.b. $\quad \mathrm{NH}_{3}$ concentrations in off-gas from FTIR for the DM100 LAW Envelope A tests. $\quad$ F-51

Figure 6.4. $\quad \mathrm{SO}_{2}$ concentrations in off-gas from FTIR for the DM100 LAW Envelope B tests. $\quad$ F-52 
The Catholic University of America

Vitreous State Laboratory
LAW Envelope A and B Glass Formulations Testing

to Increase Waste Loading

Final Report, VSL-06R6900-1, Rev. 0

\section{List of Abbreviations}

$\begin{array}{ll}\text { AA } & \text { Atomic Absorption Spectroscopy } \\ \text { ADS } & \text { Air Displacement Slurry } \\ \text { ANL-LRM } & \text { Argonne National Laboratory - Low-Activity Waste Reference Material } \\ \text { CCC } & \text { Canister Centerline Cooling } \\ \text { DCP-AES } & \text { Direct Current Plasma Atomic Emission Spectroscopy } \\ \text { DF } & \text { Decontamination Factor } \\ \text { DM } & \text { DuraMelter } \\ \text { DOE } & \text { Department of Energy } \\ \text { EDS } & \text { Energy Dispersive X-ray Spectroscopy } \\ \text { EPA } & \text { Environmental Protection Agency } \\ \text { FTIR } & \text { Fourier Transform Infrared Spectroscopy } \\ \text { GC } & \text { Gas Chromatography } \\ \text { HEPA } & \text { High-Efficiency Particulate Air Filter } \\ \text { HLW } & \text { High Level Waste } \\ \text { IC } & \text { Ion Chromatography } \\ \text { IHLW } & \text { Immobilized High Level Waste } \\ \text { ILAW } & \text { Immobilized Low Activity Waste } \\ \text { LAW } & \text { Low Activity Waste } \\ \text { M } & \text { Molarity } \\ \text { N } & \text { Normality } \\ \text { ORP } & \text { Office of River Protection } \\ \text { PCT } & \text { Product Consistency Test } \\ \text { QA } & \text { Quality Assurance } \\ \text { QAPP } & \text { Quality Assurance Project Plan } \\ \text { QC } & \text { Quality Control } \\ \text { RPP } & \text { River Protection Project } \\ \text { RSD } & \text { Relative Standard Deviation } \\ \text { SEM } & \text { Scanning Electron Microscope } \\ \text { TFCOUP } & \text { Tank Farm Contractor Operation and Utilization Plan } \\ \text { TTT } & \text { Time-Temperature-Transformation } \\ \text { VHT } & \text { Vapor Hydration Test } \\ \text { VSL } & \text { Vitreous State Laboratory } \\ \text { WTP } & \text { Waste Treatment and Immobilization Plant } \\ \text { XRF } & \text { X-Ray Fluorescence } \\ & \end{array}$


The Catholic University of America Vitreous State Laboratory
LAW Envelope A and B Glass Formulations Testing

to Increase Waste Loading

Final Report, VSL-06R6900-1, Rev. 0

\section{SECTION 1.0 INTRODUCTION}

About 50 million gallons of high-level mixed waste is currently stored in underground tanks at The United States Department of Energy's (DOE's) Hanford site in the State of Washington. The Hanford Tank Waste Treatment and Immobilization Plant (WTP) will provide DOE's Office of River Protection (ORP) with a means of treating this waste by vitrification for subsequent disposal. The tank waste will be separated into low- and high-activity waste fractions, which will then be vitrified respectively into Immobilized Low Activity Waste (ILAW) and Immobilized High Level Waste (IHLW) products. The ILAW product will be disposed in an engineered facility on the Hanford site while the IHLW product will be directed to the national deep geological disposal facility for high-level nuclear waste. The ILAW and IHLW products must meet a variety of requirements with respect to protection of the environment before they can be accepted for disposal.

The Office of River Protection is currently examining options to optimize the Low Activity Waste (LAW) Facility and LAW glass waste form. One option under evaluation is to enhance the waste processing rate of the vitrification plant currently under construction. It is likely that the capacity of the LAW vitrification plant can be increased incrementally by implementation of a variety of low-risk, high-probability changes, either separately or in combination. These changes include:

- Operating at the higher processing rates demonstrated at the LAW pilot melter

- Increasing the glass pool surface area within the existing external melter envelope

- Increasing plant availability

- Increasing the glass waste loading

- Operating the melter at a slightly higher temperature

- Other smaller impact changes

The Vitreous State Laboratory at The Catholic University of America (VSL) and Duratek, Inc. have evaluated several of these potential incremental improvements for ORP in support of its evaluation of WTP LAW facility optimization [1]. Some of these incremental improvements have been tested at VSL, including increasing the waste loading, increasing the processing temperature, and increasing the fraction of the sulfur in the feed that is partitioned to the off-gas stream (assuming that the present WTP recycle loop can be broken) [2-4]. These approaches successfully demonstrated increases in glass production rates and significant increases in sulfate incorporation for an LAW Envelope A glass with $20 \mathrm{wt} \% \mathrm{Na}_{2} \mathrm{O}$. The current work focuses on further development and testing of enhanced glass formulations for all of the LAW waste envelopes to increase waste loading in the glass product, which will reduce the amount of glass to be produced by the WTP for the same amount of waste processed. The testing 
The Catholic University of America Vitreous State Laboratory
LAW Envelope A and B Glass Formulations Testing

to Increase Waste Loading

Final Report, VSL-06R6900-1, Rev. 0

is also designed to determine sulfur retention in the glass product and production rate increases at slightly higher than nominal glass processing temperatures.

For a large number of Hanford LAW waste streams, sulfur is the main component that limits waste loading in the glasses. For some LAW Envelope A waste streams with low sulfate contents, the alkali concentration becomes the waste loading limiting factor. When processing melter feeds with very high sulfate concentrations, a molten sulfate salt phase can form in the cold-cap region during processing. This phase may exist as transient droplets or can be sufficiently extensive to produce a separate salt phase that becomes mechanically disengaged from the rest of the cold cap. Once formed, the salt phase is slow to dissolve into the underlying glass melt; consequently, the salt phase typically forms before the underlying glass melt is saturated with sulfate [5-8]. If the feed rate is sufficiently low (which is clearly undesirable), the equilibrium sulfate saturation concentration in the glass can be approached more closely before a separate salt phase forms. However, in general, as the feed rate is increased, for the same sulfate concentration in the feed, the salt phase appears progressively earlier. Thus, in practice, the formation of a sulfate phase is governed by both thermodynamic and kinetic factors and, therefore, the effects of both must be considered in order to avoid the formation of such phases during operations.

The presence of the corrosive, low-melting, electrically conductive salt phase is undesirable from the perspectives of melter operation, melter lifetime, safety, and product quality. Accordingly, the WTP plans to control the composition of the LAW melter feed such that formation of a separate salt phase is avoided. Clearly, the control bounds that are imposed will determine the achievable waste loading limits and, therefore, will determine the waste processing rate for a given glass production rate (i.e., melter capacity). A convenient gross metric that has been employed as a planning basis for the WTP is the so-called "rule-of-five", which states that salt phase separation should not be observed for LAW glass waste loadings such that the product of the $\mathrm{Na}_{2} \mathrm{O}$ and $\mathrm{SO}_{3}$ contents (in wt\%) in the glass is below five [5]. Clearly, however, the magnitude of this product that is achievable also depends on the concentrations of other components in the glass, as well as other factors. It is recognized, and melter tests have confirmed that, except for the highest sulfate waste streams, which lead to glasses with the lowest sodium concentrations, there is some conservatism in this metric [9-30]. In fact, recent VSL glass formulation development and melter testing for ORP [2] showed sulfate loadings of up to $1.2 \mathrm{wt} \% \mathrm{SO}_{3}$ in a LAW Envelope A glass containing $20 \mathrm{wt} \% \mathrm{Na}_{2} \mathrm{O}$. Based on the results of this recent testing, ORP requested that further testing be performed to demonstrate higher sodium and sulfate loading for all of the LAW waste envelopes. Thus, one of the main objectives of the present glass formulation work was to develop LAW feed and glass formulations that significantly improve upon the rule-of-five-based waste loadings for the LAW Envelopes B and $\mathrm{C}$ wastes; a further objective for Envelope A wastes was to investigate sodium oxide loadings above 20 wt $\%$.

The tests with LAW Envelope A and B wastes described in this final report were performed in accordance with the corresponding Test Plan that was prepared for ORP [31], which in turn was prepared in response to an amendment to the LAW Pilot Melter decommissioning and testing letter subcontract [1]. Analogous tests with LAW Envelope C 
The Catholic University of America Vitreous State Laboratory
LAW Envelope A and B Glass Formulations Testing

to Increase Waste Loading

Final Report, VSL-06R6900-1, Rev. 0

waste covered by the same Test Plan were reported previously [32]. The approach to completing this work included crucible-scale tests to identify glass compositions that lead to increased sulfate solubility and sulfate incorporation rates, screening tests on the DM10 melter, and confirmation tests on the DM100 melter.

Under a separate contract to support the WTP Project, the VSL is developing and testing glass formulations for RPP-WTP waste envelopes to provide data to meet the RPP-WTP contract requirements and to support system design activities [33-36]. That work is based upon small-scale batch melts ("crucible melts") using waste simulants. Selected formulations have also been tested in small-scale, continuously-fed, joule-heated melters (DM10 and DM100 systems) [7-18] and, ultimately, in the LAW Pilot Melter [19-30]. Such melter tests provide information on key process factors such as feed processing behavior, dynamic effects during processing, sulfate incorporation, processing rates, off-gas amounts and compositions, foaming control, etc., that cannot be reliably obtained from crucible melts. This sequential scale-up approach in the vitrification testing program ensures that maximum benefit is obtained from the more costly melter tests and that the most effective use is made of those resources. In addition, this considerable amount of test data provides confidence in the predictability of tests performed on the smaller scale melter systems.

Under the WTP support effort, VSL and Duratek have developed and identified glass compositions for processing the Phase I LAW tank waste streams for the WTP. These compositions have been tested for processing and product quality requirements at various scales ranging from crucible melts of about $400 \mathrm{~g}$, up to LAW Pilot Melter at processing rates in excess of $6600 \mathrm{~kg} /$ day $\left(2000 \mathrm{~kg} / \mathrm{m}^{2} /\right.$ day). The testing included the nominal feed compositions and those with $\pm 15 \%$ variations in the waste simulants added to the melter feeds. The melter testing provided high confidence that the selected WTP compositions are unlikely to cause accumulation of a separate sulfate phase in the melter, even at high feed processing rates. Feed processing characteristics and off-gas characteristics have been determined at various melter scales, and data have been collected to support engineering and permitting requirements. Furthermore, statistically designed composition matrices were generated, and crucible melts of these glass compositions were prepared and characterized to qualify the glass composition region covering these LAW glass compositions selected for WTP waste processing. The selected WTP compositions have also been tested to ensure their compatibility with melter materials of construction. Thus, the glass formulation development and melter testing work for the selected WTP compositions have reached a level of maturity where the compositions can be used for waste processing at the WTP with relatively high confidence.

The glass formulation and melter testing work presented in this report was aimed at identifying glass compositions that have the potential to accommodate higher waste loadings. This information provides ORP with a basis for evaluation of the likely potential for future enhancements of the WTP, over and above the present well-developed baseline. In this regard, the work presented in this report is complementary to and necessarily of a more exploratory nature than the work performed in support of the current WTP baseline. It should be noted, therefore, that to the extent that the present effort was successful, considerable further work 
The Catholic University of America Vitreous State Laboratory
LAW Envelope A and B Glass Formulations Testing

to Increase Waste Loading

Final Report, VSL-06R6900-1, Rev. 0

would be required to bring the level of confidence in the new glass composition regions to a similar level of maturity to that of the current WTP baseline.

The melter tests described in this report utilized blended feed (glass formers plus waste simulant) prepared by Optima Chemicals according to VSL specifications. Sufficient feed was prepared to produce over seventeen hundred kilograms of glass. Reductant in the form of sugar was added to the feed at a stoichiometric ratio of 0.5 ( 1 mole sucrose per 16 moles NOx or 3 moles carbon per 4 moles $\mathrm{NOx}$ ). The feed was procured from Optima at $\mathrm{Na}_{2} \mathrm{O}$ and $\mathrm{SO}_{3}$ concentrations slightly below target values and adjusted to desired concentrations by the addition of various combinations of $\mathrm{NaOH}$ and $\mathrm{Na}_{2} \mathrm{SO}_{4}$. The DM10 melter was used to determine the processability of the feed and to determine the maximum feed $\mathrm{SO}_{3}$ concentrations at melter operating temperatures of $1150^{\circ} \mathrm{C}$ and $1175^{\circ} \mathrm{C}$. Based on these results, two DM100 tests were conducted for each waste composition, one at $1150^{\circ} \mathrm{C}$ and one at $1175^{\circ} \mathrm{C}$. The starting feed $\mathrm{SO}_{3}$ concentrations for the DM100 tests were based on the results of DM10 melter tests. The DM100-WV melter was used in order to provide a direct comparison with the LAW tests previously conducted on the same melter [2-4, 7-18]. The bubbling rate was adjusted to achieve a target glass production rate of $2250 \mathrm{~kg} / \mathrm{m}^{2} /$ day with a near-complete cold cap (90-100\% of melt surface covered with feed) for DM100 tests conducted at $1150^{\circ} \mathrm{C}$. The average bubbling rate from the steady-state portion of the $1150^{\circ} \mathrm{C}$ test was used in the subsequent test conducted at $1175^{\circ} \mathrm{C}$ in order to determine the effect of the temperature increase on production rate. Quantitative measurements of glass production rates, melter operating conditions (temperatures, pressures, power, flows, etc.), and off-gas characteristics ( $\mathrm{NOx}, \mathrm{SO}_{2}, \mathrm{CO}$, particulate load and composition, and acid gases) were made for each test. Glass samples taken from the glass pool and the air-lift discharged glass were inspected throughout testing to determine the limit of feed $\mathrm{SO}_{3}$ concentration for operation of the melter without a separate sulfate phase.

\section{$1.1 \quad$ Test Objectives}

The principal objective of the work described in this final report was to identify and demonstrate methods to increase waste loadings in LAW Envelope A and B glass formulations while maintaining compliance with the current LAW glass performance requirements. This was accomplished through a combination of crucible-scale tests, screening tests on the DM10, and confirmation tests on the DM100 melter system. The DM100-WV unit was selected for these tests. The DM100-WV was used for all of the previous tests on LAW A, B, and C Sub-Envelopes [7-18] that were used to support the subsequent tests on the LAW Pilot Melter [19-30]. The same melter was selected for the present tests in order to maintain comparisons between the data sets. These tests provide information on melter processing characteristics and off-gas data, including sulfur incorporation and partitioning.

The work focused on increasing the waste loading for LAW Envelope A and B wastes as well as evaluating the potential production rate increases in response to a modest increase in melter operating temperature. 
The principal objectives of this work were to [31]:

- Extend the glass formulation methodology developed in the first phase of this effort [2, 3] for Envelope A waste to Envelope B waste. Develop and test a LAW Envelope $\mathrm{B}$ glass composition with a target $\mathrm{Na}_{2} \mathrm{O}$ concentration of $10 \mathrm{wt} \%$ and a target minimum $\mathrm{SO}_{3}$ concentration of $1.2 \mathrm{wt} \%$.

- Develop and test LAW Envelope A glass formulations with increased sodium loadings such that the $\mathrm{Na}_{2} \mathrm{O}$ concentration in the glass is greater than $20 \mathrm{wt} \%$ (target $\mathrm{Na}_{2} \mathrm{O}$ and $\mathrm{SO}_{3}$ concentrations of $23 \mathrm{wt} \%$ and $1.2 \mathrm{wt} \%$, respectively).

- Determine the effect of a modest increase in melter operating temperature on production rate and sulfur retention in the glass product for LAW Envelope A and B waste streams.

\subsection{Quality Assurance}

This work was conducted under a quality assurance program that is in place at the VSL that is based on NQA-1 (1989) and NQA-2a (1990) Part 2.7. This program is supplemented by a Quality Assurance Project Plan [37] for WTP work that is conducted at VSL. Test and procedure requirements by which the testing activities were planned and controlled are defined in the Test Plan [31]. The program is supported by VSL standard operating procedures that were used for this work [38]. The requirements of DOE/RW-0333P are not applicable to this work.

\subsection{DM100 Melter System Description}

\subsubsection{Feed System}

A schematic diagram of the DM100 vitrification system is shown in Figure 1.1. The melter feed is introduced in batches into a feed container that is mounted on a load cell for weight monitoring. The feed is stirred with a variable speed mixer and constantly recirculated except for periodic, momentary interruptions during which the weight is recorded. The way in which the feed is introduced into the melter is designed to mimic the operation of an ADS pump, which is the present WTP baseline. The recirculation loop extends to the top of the melter where feed is diverted from the recirculation loop into the melter through a Teflon-lined feed line and water-cooled feed tube. Two computer-operated pinch valves, one on the feed line and one on the recirculation loop, are activated in a timed sequence to introduce feed into the melter at the desired rate. The feed rate is regulated by adjusting the length of each pulse, the time between each pulse, and the pressure applied to the recirculation loop. A compressed air line is attached to the feed line and can be used to automatically clear the feed line into the melter after each pulse. The mixed feed enters the melter through a water-cooled, vertical feed tube. 
The Catholic University of America Vitreous State Laboratory
LAW Envelope A and B Glass Formulations Testing

to Increase Waste Loading

Final Report, VSL-06R6900-1, Rev. 0

\subsubsection{Melter System}

Cross-sectional diagrams through the DM100-WV melter are shown in Figures 1.2a-c. The DM100-WV unit is a ceramic refractory-lined melter fitted with a pair of opposing Inconel 690 plate electrodes as well as a bottom electrode. The melter can be operated with either three-phase or single-phase power. However, the standard mode of operation, which was used for these tests, is single-phase with voltage applied to the side electrodes only. The bubbler used for stirring the melt pool enters from the top and is removable. The glass product is removed from the melter by means of an air-lift discharge system. The DM100-WV has a melt surface of $12 \times 14$ inches, giving a melt surface area of $0.108 \mathrm{~m}^{2}$. The nominal depth of the melt pool is about 19 inches, which gives a typical glass inventory of between 115 and $120 \mathrm{~kg}$. The plenum height is 27.5 inches. Temperatures are monitored by means of a series of thermocouples located in the melt pool, the electrodes, the plenum space, and the discharge chamber.

\subsubsection{Off-Gas System}

For operational simplicity, the DM100-WV is equipped with a dry off-gas treatment system involving gas filtration operations only. Exhaust gases leave the melter plenum through a film cooler device that minimizes the formation of solid deposits. The film-cooler air has constant flow rate and its temperature is thermostatically controlled. Consequently, under steady-state operating conditions, the exhaust gases passing through the transition line (between the melter and the first filtration device) can be sampled at constant temperature and airflow rate. The geometry of the transition line conforms to the requirements of the 40-CFR-60 air sampling techniques. Immediately downstream of the transition line are cyclonic filters followed by conventional pre-filters and HEPA filters. The temperature of the cyclonic filters is maintained above $150^{\circ} \mathrm{C}$ while the temperatures in the HEPAs are kept sufficiently high to prevent moisture condensation. The entire train of gas filtration operations is duplicated and each train is used alternately. An induced draft fan completes the system. 


\section{SECTION 2.0 WASTE SIMULANT AND GLASS FORMULATIONS}

\subsection{Envelope A Waste Simulant and Glass Formulation}

Glass formulation development and testing for LAW Envelope A were based on the composition of LAW material from Hanford tank AN-105. Details of the waste simulant, and glass formulation development and testing are given below.

\subsubsection{Envelope A Waste Simulant}

The LAW Envelope A waste simulant used in the studies reported here is based on the composition data for tank AN-105 as given in a WTP Test Specification [39]; however, the sulfate concentration was increased from 0.6 to $2.7 \mathrm{wt} \% \mathrm{SO}_{3}$ in order to meet the requirements of the present tests. The base waste composition incorporates TFCOUP [40] data, actual waste analysis data, and WTP flow sheet information. The sodium concentration in the simulant includes a $2.5 \%$ increase to account for sodium additions in pretreatment $[34,41]$. The nominal concentration, expressed in terms of the sodium molarity, was determined on the basis of melter feed rheology tests on similar formulations $[42,43]$. The results of those tests led to the selection of 8.0 molar sodium as the nominal simulant concentration for the LAW AN-105 waste. This is the same concentration that was used for previous WTP melter tests for LAW AN-105 waste [9, $16]$.

The nominal simulant formulation is given in Table 2.1. The LAW AN-105 simulant is a solution of predominantly sodium, aluminum, nitrate, nitrite, and sulfate. Since the simulant was similar to those tested previously at the VSL, new laboratory samples were not prepared and tested. For the melter tests, Optima Chemicals, who supplied all of the LAW simulants for the previous DM100 and LAW Pilot Melter studies, prepared the waste simulant and added the glass forming chemicals before shipment to VSL in 55-gallon drums. Sugar as a reductant, and the requisite combinations of sodium hydroxide and sodium sulfate to adjust the sodium and sulfur contents of the feed for each test, were added at VSL.

\subsubsection{Envelope A Glass Formulation}

Glass formulation development for LAW Envelope A was based on the composition of the LAW AN-105 waste stream. The objective was to develop a glass formulation containing a minimum of $23 \mathrm{wt} \% \mathrm{Na}_{2} \mathrm{O}$ and increased concentrations of sulfate. Since development of a very high sodium and high sulfate formulation was considered to be the most challenging, substantial effort was focused on the Envelope A glass formulation development. Seventeen crucible melts were prepared with $23 \mathrm{wt} \% \mathrm{Na}_{2} \mathrm{O}$, and a further ten were prepared with $25 \mathrm{wt} \% \mathrm{Na}_{2} \mathrm{O}$. The 
The Catholic University of America Vitreous State Laboratory
LAW Envelope A and B Glass Formulations Testing

to Increase Waste Loading

Final Report, VSL-06R6900-1, Rev. 0

concentrations of additives such as $\mathrm{CaO}, \mathrm{Al}_{2} \mathrm{O}_{3}, \mathrm{~B}_{2} \mathrm{O}_{3}, \mathrm{ZrO}_{2}$ and $\mathrm{SiO}_{2}$ were varied to determine their effect on key properties of interest such as sulfate solubility, B, Na and Si mass loss on Product Consistency Test (PCT) per ASTM C1285, glass alteration rate by nominal 24-day Vapor Hydration Test (VHT), and K-3 refractory corrosion. $\mathrm{V}_{2} \mathrm{O}_{5}$ was included as an additive in every crucible melt based on the results from previous testing [2, 4-8]. $\mathrm{SnO}_{2}$ was added to improve the performance of the glass on VHT based on previous test results [44], while $\mathrm{Cr}_{2} \mathrm{O}_{3}$ was added to reduce refractory corrosion with these high-alkali compositions. Previous development work [2, 4-8] for Hanford LAW tanks has indicated that the glass former additives with the most impact on sulfate solubility in the glass are lithium and calcium, with lesser effect for boron, and iron; additions of vanadium have also been shown to be beneficial for some compositions [2, 4-8]. Lithium additions were not tested because the glass already contains high concentrations of alkali oxides (23 or $25 \mathrm{wt} \% \mathrm{Na}_{2} \mathrm{O}$ ). Previous testing [34, 35] has shown that addition of lithium to glasses that already contain high concentrations of other alkali oxides will likely result in unacceptable refractory corrosion characteristics, and higher leach rates.

Target and analyzed compositions of the Envelope A glasses that were tested at $23 \mathrm{wt} \%$ $\mathrm{Na}_{2} \mathrm{O}$ and 25 wt\% $\mathrm{Na}_{2} \mathrm{O}$ are given in Tables 2.2 and 2.3, respectively. Glass compositions were determined by $\mathrm{x}$-ray fluorescence spectroscopy (XRF) on powdered glass samples, except for $\mathrm{B}_{2} \mathrm{O}_{3}$, which was measured by direct current plasma - atomic emission spectroscopy (DCP-AES) after acid dissolution. As expected, measured concentrations of volatile components such as $\mathrm{Cl}$ and $\mathrm{SO}_{3}$ are lower than target. As is evident from the tables, the target and analyzed compositions show good agreement. Testing of all formulations started with glass preparation and optical microscopic evaluation of the as-melted sample. Glass samples were heat treated for 20 hours at $850^{\circ} \mathrm{C}$ and $950^{\circ} \mathrm{C}$, and evaluated for secondary phases. Observations on the as-melted, and heat treated glasses are given in Tables 2.4 and 2.5 for glasses containing $23 \mathrm{wt} \%$ and $25 \mathrm{wt} \% \mathrm{Na}_{2} \mathrm{O}$, respectively. Most of the as-melted glasses appeared clear with a green color. Some of the heat treated glasses showed evidence of crystals with sodalite structures containing $\mathrm{Na}, \mathrm{Al}$, and Si being one of the more common phases. Other phases that were identified include Cr-Zn-Al-Mg spinels, and zirconium silicate containing Sn and Na.

From Tables 2.4 and 2.5, it is apparent that the samples heat treated at $850^{\circ} \mathrm{C}$, in general, contain more crystals than the samples heat treated at $950^{\circ} \mathrm{C}$. This is expected because of the thermodynamic and kinetic factors that control crystallization from the glass phase and their dependence on temperature. At the liquidus temperature (about $950^{\circ} \mathrm{C}$ to $1000^{\circ} \mathrm{C}$ for these glasses), the glass and crystal phases have the same free energy and, therefore, there is no thermodynamic driving force for crystallization. At lower temperatures, the crystal phase has a lower free energy than the glass phase, and this free energy difference, which increases as the temperature is lowered, is the thermodynamic driving force for crystallization. The kinetics of crystal formation and growth are more favorable at the higher temperatures because the higher diffusion coefficients allow easier movement of atoms. At lower temperatures, the diffusion coefficients become smaller, and movement of atoms becomes a much slower process. Due to these competing factors, crystallization becomes most favorable at some temperature below the liquidus temperature. The temperature of maximum crystallization will depend on the glass composition, and consequently, on the types of crystalline phases that are formed on heat 
The Catholic University of America Vitreous State Laboratory
LAW Envelope A and B Glass Formulations Testing

to Increase Waste Loading

Final Report, VSL-06R6900-1, Rev. 0

treatment. For glasses with a liquidus temperature of about $1000^{\circ} \mathrm{C}$, the temperature of maximum crystallization will generally be in the range of $700^{\circ} \mathrm{C}$ to $900^{\circ} \mathrm{C}$ depending on the type(s) of crystals that are formed. In glasses that predominantly crystallize one secondary phase, samples heat treated both above and below the temperature of maximum crystallization will contain fewer crystals, with the amount of crystals decreasing gradually on moving the heat treatment temperature away from the temperature of maximum crystallization towards lower or higher temperatures. This type of response of crystallization with heat treatment temperature is observed in time-temperature-transformation (TTT) curves, where the nose of the TTT diagram corresponds to the temperature of maximum crystallization. For glasses that on heat treatment crystallize more than one phase in significant quantities, the response is more complicated, with potentially more than one peak in the volume percent crystals versus heat treatment temperature curve. For the LAW Envelope A and B glasses reported here, the temperature of maximum crystallization is $850^{\circ} \mathrm{C}$ or lower, and therefore, at the higher heat treatment temperature of $950^{\circ} \mathrm{C}$, smaller amounts of crystals are observed.

The sulfate solubilities of the LAW Envelope A glass compositions were assessed in two ways by using both batch saturation tests and gas bubbling tests. Both of these tests are crucible-scale screening tests that are used to obtain an indication of the extent of sulfur incorporation that will be obtained under actual melter operating conditions, which is, of course, the factor that is of practical importance. From past experience, the results from batch saturation tests are the simplest to perform and provide reasonable rankings of glass compositions, whereas the results from the gas bubbling tests are often in closer quantitative agreement with the results from melter tests. The batch saturation tests were performed by remelting finely ground samples of the glasses with an excess of sulfate amounting to $4 \mathrm{wt} \% \mathrm{SO}_{3}$ if all of it were retained in the glass; the addition of an " $\mathrm{S}$ " at the end of a sample name indicates that the sample was remelted in this way. Results of sulfate batch saturation tests are given in Table 2.6. The analyzed compositions identified as "XRF" are the results of XRF analyses of glass samples remelted with $4 \mathrm{wt} \% \mathrm{SO}_{3}$. The compositions identified as "XRF after washing" are analyses of glass samples remelted with $4 \mathrm{wt} \% \mathrm{SO}_{3}$ after grinding and washing to remove any interstitial sulfate phases, to ensure that only the $\mathrm{SO}_{3}$ that is dissolved in the glass is measured. The sulfate retentions of the glasses ("XRF after washing”) varied from about 0.64 wt\% $\mathrm{SO}_{3}$ for $\mathrm{LAWA} 95$ to $1.06 \mathrm{wt} \% \mathrm{SO}_{3}$ for LAWA178.

As stated above, sulfate solubilities of the new LAW Envelope A glasses were also determined by gas bubbling tests. In this test, a sample of the test glass that does not contain any sulfate is melted in a platinum crucible and held at a constant temperature of $1150^{\circ} \mathrm{C}$. Mixtures of $\mathrm{SO}_{2}$ and $\mathrm{O}_{2}$ are then bubbled through the glass melt at controlled flow rates through a platinum tube. From the flow rates and the temperature, together with known thermodynamic data, the partial pressure of $\mathrm{SO}_{3}$ can be calculated. Samples of the glass melt are removed at selected time intervals and subjected to analysis by XRF to determine their sulfur content. Prior to analysis, the glass samples are ground and washed to remove any sulfate phase that might adhere to the sample in order to determine only the sulfate that is dissolved in the glass. Figure 2.1 shows the results of these tests for one of the new glasses, LAWA187; also shown are the results for a previously tested high sulfate ORP LAW Envelope A glass (LAWA161), and a 
The Catholic University of America Vitreous State Laboratory
LAW Envelope A and B Glass Formulations Testing

to Increase Waste Loading

Final Report, VSL-06R6900-1, Rev. 0

WTP LAW glass formulation (LAWA44) which showed lower sulfate incorporation. The results show that the new LAW Envelope A glass and LAWA161 exhibit similar sulfate incorporation and, compared to LAWA44, a significant increase in sulfate incorporation both in terms of a higher solubility limit and a lower activity coefficient for $\mathrm{SO}_{3}$ in the melt. The results of sulfate solubility determinations by batch saturation tests and gas bubbling tests are given in Figure 2.2. The glass composition that was selected for melter tests, LAWA187, is identified in Figure 2.2, and had one of the higher sulfate solubilities $\left(\sim 1.1 \mathrm{wt} \% \mathrm{SO}_{3}\right)$ as determined by the gas bubbling tests.

VHT and PCT results are summarized in Table 2.7 and illustrated in Figures 2.3 and 2.4. VHT results given in Table 2.7 and Figure 2.3 show that a number of glasses exceeded the VHT alteration rate requirement of $50 \mathrm{~g} / \mathrm{m}^{2} /$ day. This was not unexpected because both VHT and PCT requirements become more challenging as the alkali contents of the glasses are increased. It should also be noted that VHT results have to be considered with a fairly large relative standard deviation estimated at about $43 \%$ on average, based on replicate VHT measurements [45]. PCT responses for the glasses given in Table 2.7 and Figure 2.4 show that all but one of the glasses met the ILAW product quality requirement of normalized mass loss of less than $2 \mathrm{~g} / \mathrm{m}^{2}$ for $\mathrm{B}$, $\mathrm{Na}$, and $\mathrm{Si}$. The only glass that failed the requirement, LAWA177, was a glass that contained 25 wt $\% \mathrm{Na}_{2} \mathrm{O}$. The measured viscosities and electrical conductivities of the glasses at select temperatures, all of which are in the acceptable range for processing in the melter, are given in Table 2.8. The densities for all the glasses, and the glass transition temperature for the selected formulation (LAWA187), are given in Table 2.9. Due to the high alkali content of the new LAW Envelope A glass formulations, K-3 refractory corrosion was a significant concern and, therefore, most of the glasses were tested for their K3 corrosion characteristics. K-3 refractory corrosion test results for the glasses are given in Table 2.10 and Figure 2.5, where they are compared to the results for the previously tested ORP LAW Envelope A glass (LAWA161) and two WTP baseline formulations with $20 \mathrm{wt} \% \mathrm{Na}_{2} \mathrm{O}$ (LAWA44 and LAWA88). A number of the crucible melts with $25 \mathrm{wt} \% \mathrm{Na}_{2} \mathrm{O}$ had unacceptable K-3 corrosion characteristics, which could impact melter life. Acceptability of the corrosion characteristics of a glass composition is somewhat subjective because a glass composition that shows slightly higher K-3 corrosion, but allows higher waste loading, may be a more economic choice than one with lower K-3 corrosion and lower waste loading. However, for WTP LAW glass formulation development, a neck corrosion of 0.035 inches on 6-day K-3 coupon corrosion test at $1208^{\circ} \mathrm{C}$ has been used as an acceptance limit. For the current LAW glass formulation development work for ORP, since higher waste loading compositions are being explored, a slightly higher neck corrosion value of 0.040 inches has been used as a guide for acceptable corrosion characteristics. All of the ORP LAW glasses selected for melter tests, however, show neck corrosion of less than 0.035 inches.

Waste loading and sulfate solubility alone could not be used to guide the selection of a new glass formulation for melter testing because a review of the property data for the 27 new crucible melts showed that a number of the formulations do not have acceptable PCT, VHT, or K-3 corrosion characteristics. A crucible melt designated LAWA187 with $23 \mathrm{wt} \% \mathrm{Na}_{2} \mathrm{O}$ had one of the highest sulfate solubilities, and acceptable processing and product quality requirements and was, therefore, selected for melter testing. The measured properties of the glass LAWA187 are compared to the ILAW performance requirements [46] in Table 2.11. As is evident from 
The Catholic University of America Vitreous State Laboratory
LAW Envelope A and B Glass Formulations Testing

to Increase Waste Loading

Final Report, VSL-06R6900-1, Rev. 0

Table 2.11, glass LAWA187 meets all of the ILAW performance requirements. A sample of the glass was subjected to canister center line cooling (CCC) heat treatment and analyzed. The CCC profile that was used in the heat treatment is given in Figure 2.6 and is based on canister cooling data from LAW Pilot Melter testing. Per WTP guidance [47], this CCC profile is currently used for all WTP glass formulation testing. Images of the heat treated sample are given in Figure 2.7. Heat treatment was done in a crucible with depth and top diameter of about 1 inch each. The heat treated sample showed a sodalite phase crystallization starting at the crucible surface and extending about 4-5 mm into the bulk of the glass, with clear glass at the center of the crucible. The maximum crystal concentration near the surface of the platinum crucible was about 20 vol\%. Energy dispersive x-ray spectroscopy (EDS) analysis of the sodalite phase provided in Figure 2.8 shows that the crystals preferentially incorporate $\mathrm{Cr}, \mathrm{Cl}$ and $\mathrm{S}$. The composition of the clear glass at the center of the sample matched the target composition, while the glass around the sodalite crystals was deficient in $\mathrm{Cr}, \mathrm{S}$, and $\mathrm{Cl}$. It should be noted that one of the glass formulation strategies to improve sulfate loading is to facilitate formation of sodalite type phases that incorporate sulfur in the melter cold-cap to prevent formation of a secondary sulfate phase, thereby increasing the acceptable sulfate loading in the melter feed. Therefore, it is not surprising that this composition has a tendency to crystallize sodalite phases. However, the sectioned samples strongly suggest that the crystallization is a surface-induced phenomenon rather than bulk crystallization and, as such, would not be expected to be present in an actual LAW container where the surface is cooler than the bulk, the container is made of a different material (i.e., not platinum), and the surface to volume ratio is much smaller. Larger scale CCC tests are recommended to confirm that the crystallization that is observed is indeed a surface phenomenon, and that the bulk of the glass is unlikely to be affected. In addition, as mentioned before, development of a glass formulation that contains both very high $\mathrm{Na}_{2} \mathrm{O}(>20 \mathrm{wt} \%)$ and $\mathrm{SO}_{3}(>1.0 \mathrm{wt} \%)$ is very challenging. For the very significant fraction of Hanford LAW waste streams where waste loading is limited solely by sodium loading and not sulfate, it is recommended that glass formulations be developed that allow very high $\mathrm{Na}_{2} \mathrm{O}(>20$ wt\%) loading without simultaneously imposing such a high sulfate requirement.

The composition of the LAWA187 glass used in melter tests is given in Table 2.12 along with the oxide contributions from the LAW AN-105 waste simulant and from the glass former additives. The melter feed was procured at a $\mathrm{SO}_{3}$ concentration of $0.80 \mathrm{wt} \%$ and the sulfur concentration was increased in steps during the melter tests by adding the appropriate amounts of $\mathrm{Na}_{2} \mathrm{SO}_{4}$ and $\mathrm{NaOH}$ to the feed. The melter feed was procured at a $\mathrm{Na}_{2} \mathrm{O}$ concentration of $22.69 \mathrm{wt} \%$ in order to accommodate sodium sulfate additions, without increasing the $\mathrm{Na}_{2} \mathrm{O}$ concentration above $23.0 \mathrm{wt} \%$. The types and amounts of glass former additives used to prepare the melter feed along with the feed properties are given in Table 2.13. The glass former additives are the same as those planned for use at the WTP, with the exception of vanadium and tin, which were added to improve sulfate solubility [2, 4-8] and VHT performance [44], respectively. The amounts of $\mathrm{Na}_{2} \mathrm{SO}_{4}$ and $\mathrm{NaOH}$ to be added to the feed to obtain $23 \mathrm{wt} \% \mathrm{Na}_{2} \mathrm{O}$ and 0.80 to 1.20 $\mathrm{wt} \% \mathrm{SO}_{3}$ are given in Table 2.14. 
The Catholic University of America

Vitreous State Laboratory
LAW Envelope A and B Glass Formulations Testing

to Increase Waste Loading

Final Report, VSL-06R6900-1, Rev. 0

\subsection{Envelope B Waste Simulant and Glass Formulation}

Glass formulation development and testing for LAW Envelope B were based on the composition of LAW material from Hanford tank AZ-102. Details of the waste simulant and glass formulation development and testing are given below.

\subsubsection{Envelope B Waste Simulant}

The LAW Envelope B waste simulant used in the studies reported here is based on the composition data for tank AZ-102 as given in a WTP Test Specification [39]; however, the sulfate concentration was decreased from 12.5 to $8.6 \mathrm{wt} \% \mathrm{SO}_{3}$ in order to meet the requirements of the present tests. This incorporates TFCOUP [40] data, actual waste analysis data, and WTP flow sheet information. The sodium concentration in the simulant includes a $5.33 \%$ increase to account for sodium additions in pretreatment [34, 41]. The nominal concentration, expressed in terms of the sodium molarity, was determined on the basis of melter feed rheology tests on similar formulations $[42,43]$. The results of those tests led to the selection of a 4.0 molar sodium as the nominal simulant concentration for the LAW AZ-102 waste for the current melter tests. This concentration is substantially higher than the 1.3 molar sodium used in previous WTP melter tests [13] with this waste stream due to the much higher waste loading achieved in the present study. Previous tests using LAW AZ-102 waste streams used glass compositions that could accommodate lower concentrations of $\mathrm{SO}_{3}$ and which, therefore, had lower waste loadings. Melter feeds for glass compositions at lower waste loading require more dilute waste simulants because larger quantities of glass former additives are needed per unit volume of waste simulant.

The nominal simulant formulation is given in Table 2.15. The LAW AZ-102 simulant is a solution of predominantly sodium, carbonate, nitrate, nitrite, and sulfate. Samples of the simulant were prepared according to Table 2.15 and tested at VSL. Feeds for the melter tests were prepared by Optima Chemicals and handled in a manner similar to that for the LAW Envelope A feeds, as described in Section 2.1.1.

\subsubsection{Envelope B Glass Formulation}

Glass formulation development for LAW Envelope B was based on the composition of the LAW AZ-102 waste stream. The objective was to develop a glass formulation containing $10 \mathrm{wt} \% \mathrm{Na}_{2} \mathrm{O}$ that can accommodate increased concentrations of sulfate (target minimum values of $10 \mathrm{wt} \% \mathrm{Na}_{2} \mathrm{O}$ and $1.2 \mathrm{wt} \% \mathrm{SO}_{3}$ ). Nine crucible melts were prepared with $10 \mathrm{wt} \% \mathrm{Na}_{2} \mathrm{O}$ and varying concentrations of additives such as $\mathrm{CaO}, \mathrm{Li}_{2} \mathrm{O}, \mathrm{Al}_{2} \mathrm{O}_{3}, \mathrm{~B}_{2} \mathrm{O}_{3}$, and $\mathrm{SiO}_{2}$. Based on the results from previous testing [2, 4-8], $\mathrm{V}_{2} \mathrm{O}_{5}$ was included as an additive in every crucible melt. Since previous development work for Hanford LAW tanks has indicated that the glass former additives with the most impact on sulfate solubility in the glass are $\mathrm{Li}_{2} \mathrm{O}$ and $\mathrm{CaO}$ [2, 4-8], they were maintained at relatively high concentrations of about 3-4 and 8-11 wt\%, respectively. 
The Catholic University of America Vitreous State Laboratory
LAW Envelope A and B Glass Formulations Testing

to Increase Waste Loading

Final Report, VSL-06R6900-1, Rev. 0

Target and analyzed compositions of the nine new Envelope B glasses that were tested are given in Table 2.16. Glass compositions were determined by XRF on powdered glass samples, except for $\mathrm{B}_{2} \mathrm{O}_{3}$, which was measured by DCP-AES after acid dissolution. The target and analyzed compositions show good agreement except for volatile components such as $\mathrm{SO}_{3}$. Similar to LAW Envelope A, testing of all formulations started with glass preparation and optical microscopic evaluation of the as-melted sample. Glass samples were heat treated for 20 hours at $850^{\circ} \mathrm{C}$ and evaluated for secondary phases. In contrast to the Envelope A glasses, little crystallization was observed in the Envelope B samples.

The sulfate solubilities of the LAW Envelope B glass compositions were assessed using the same methods that were used for Envelope A samples (see Section 2.1.2). The batch saturation tests were performed by remelting finely ground samples of the glasses with an excess of sulfate amounting to $4 \mathrm{wt} \% \mathrm{SO}_{3}$ if all of it were retained in the glass; the addition of an " $\mathrm{S}$ " at the end of a sample name indicates that the sample was remelted in this way. Results of sulfate batch saturation tests are given in Table 2.17. The nomenclature used to identify the samples is the same as that used in Table 2.6 and described in Section 2.1.2. The sulfate retentions of the glasses ("XRF after washing") varied from about $0.88 \mathrm{wt} \% \mathrm{SO}_{3}$ for $\mathrm{LAWB102}$ to $1.08 \mathrm{wt} \% \mathrm{SO}_{3}$ for LAWB99.

Sulfate solubilities for the new LAW B glasses were also determined by gas bubbling tests, as described for LAW A glasses in Section 2.1.2. Figure 2.9 shows the results of these tests for one of the new glasses, LAWB99; also shown are the results for a previously tested high sulfate ORP LAW Envelope A glass, LAWA161, and ORP LAW Envelope C glass, LAWC100. The results show that the new LAW Envelope B glass has higher sulfate solubility than either of the other glasses. This was expected because the Envelope $\mathrm{B}$ glass has a lower $\mathrm{Na}_{2} \mathrm{O}$ content, and greater flexibility in glass formulation development was possible for addition of components such as $\mathrm{Li}_{2} \mathrm{O}$ to improve sulfate solubility. The results of sulfate solubility determinations by batch saturation tests and gas bubbling tests are given in Figure 2.10. The glass composition that was selected for melter tests, LAWB99, is identified in Figure 2.10, and had one of the highest sulfate solubilities ( $\left.1.1 \mathrm{wt} \% \mathrm{SO}_{3}\right)$ when both batch saturation and bubbling test results were considered.

VHT and PCT results for the new Envelope B glasses are summarized in Table 2.18 and illustrated in Figures 2.11 and 2.12. All of the glasses met the WTP requirements for PCT mass loss and VHT alteration rate. The measured viscosities and electrical conductivities of the glasses at select temperatures, all of which are in the acceptable range for processing in the melter, are given in Table 2.19. The densities for all the glasses and the glass transition temperature for the selected formulation (LAWB99) are given in Table 2.20. Due to their lower alkali content, K-3 refractory corrosion was less of a concern for the Envelope $\mathrm{B}$ glasses as compared to the Envelope A glasses. In addition, the $\mathrm{Li}_{2} \mathrm{O}$ concentration in the new Envelope $\mathrm{B}$ glasses was maintained at about $4.0 \mathrm{wt} \%$ or less to avoid refractory cracking, which was observed in glasses that contained higher $\mathrm{Li}_{2} \mathrm{O}$ contents [48]. Therefore, only three samples were subjected to K-3 refractory corrosion testing, and the results are given in Table 2.21 and Figure 2.13, where they are compared to the results for ORP LAW Envelope A glass (LAWA187) and two WTP baseline 
The Catholic University of America Vitreous State Laboratory
LAW Envelope A and B Glass Formulations Testing

to Increase Waste Loading

Final Report, VSL-06R6900-1, Rev. 0

formulations with $20 \mathrm{wt} \% \mathrm{Na}_{2} \mathrm{O}$ (LAWA44 and LAWA88). All three of the new Envelope B glasses had acceptable refractory corrosion characteristics.

Since all of the new Envelope B glasses met processing and product quality requirements, selection of the formulation for melter testing was based mainly on sulfate solubility. Based on this criterion, LAWB99 was selected for melter tests. The measured properties of LAWB99 are compared to the ILAW performance requirements [46] in Table 2.22. As is evident from Table 2.22, glass LAWB99 meets all of the ILAW performance requirements. A sample of the glass subjected to CCC heat treatment showed a clear homogeneous glass with no evidence of crystallization.

The composition of the LAWB99 glass used in melter tests is given in Table 2.23 along with the oxide contributions from the LAW AZ-102 waste simulant and from the glass former additives. The melter feed was procured at a $\mathrm{SO}_{3}$ concentration of $1.00 \mathrm{wt} \%$ and the sulfur concentration was increased in steps during the melter tests by adding the appropriate amounts of $\mathrm{Na}_{2} \mathrm{SO}_{4}$ and $\mathrm{NaOH}$ to the feed. The melter feed was procured at a $\mathrm{Na}_{2} \mathrm{O}$ concentration of $9.845 \mathrm{wt} \%$ in order to accommodate sodium sulfate additions, without increasing the $\mathrm{Na}_{2} \mathrm{O}$ concentration above $10.0 \mathrm{wt} \%$. The types and amounts of glass former additives used to prepare the melter feed along with the feed properties are given in Table 2.24. The glass former additives are the same as those planned for use at the WTP, with the exception of vanadium, which was added to improve sulfate solubility [2, 4-8]. The amounts of $\mathrm{Na}_{2} \mathrm{SO}_{4}$ and $\mathrm{NaOH}$ to be added to the feed to obtain $10 \mathrm{wt} \% \mathrm{Na}_{2} \mathrm{O}$ and 1.0 to $1.6 \mathrm{wt} \% \mathrm{SO}_{3}$ are given in Table 2.25. The original plan was to test $\mathrm{SO}_{3}$ concentrations up to $1.5 \mathrm{wt} \%$ with a fixed $\mathrm{Na}_{2} \mathrm{O}$ concentration of $10.0 \mathrm{wt} \%$. Since the melter tests were more successful than expected with respect to sulfate loading, $\mathrm{SO}_{3}$ concentrations up to $1.6 \mathrm{wt} \%$ were tested which resulted in the corresponding $\mathrm{Na}_{2} \mathrm{O}$ concentration in the glass being at a slightly higher than target value of $\sim 10.1 \mathrm{wt} \%$.

\subsection{Sugar Additions}

With high nitrate feeds, the addition of reductants is necessary in order to control melt foaming. Sugar, which was used for this purpose at West Valley, has also been selected as the baseline reductant for the WTP. The amount of sugar required increases with the amount of nitrates present in the feed and decreases with the amount of waste organics present in the feed, which themselves act as reductants. Excessive additions of reductants can be deleterious, leading to over-reduction of the melt and formation of sulfides and molten metals. Consequently, the oxidants and reductants in the feed must be suitably balanced. The basis for achieving this balance was developed by VSL and Duratek for the vitrification of high-sodium-nitrate feeds at Savannah River's M-Area and has been successfully applied to the processing of a wide variety of simulated WTP feeds over the past six years. In developing this approach, we elected to conservatively adopt the most reducing potential reaction as the basis for the definition of a "sugar" or stoichiometric ratio of 1.0 as a result of concerns for over-reducing the melt. Such a reaction, using sodium salts as an example, is: 
The Catholic University of America Vitreous State Laboratory
LAW Envelope A and B Glass Formulations Testing

to Increase Waste Loading

Final Report, VSL-06R6900-1, Rev. 0

$$
\mathrm{C}_{12} \mathrm{H}_{22} \mathrm{O}_{11}+8 \mathrm{NaNO}_{3}=8 \mathrm{CO}_{2}+4 \mathrm{CO}+4 \mathrm{~N}_{2}+11 \mathrm{H}_{2} \mathrm{O}+4 \mathrm{Na}_{2} \mathrm{O}
$$

Fundamentally, the basis that is selected is simply a convention, since the precise stoichiometry of the reactions involved is neither known nor constant under the conditions prevailing in the melter. However, with this convention, a sugar ratio of 1.0 corresponds to one mole of sucrose per eight moles of nitrate or, more generally, 1.5 moles of organic carbon per mole of nitrate. It is then expected that significantly less sugar than this will be required in practice. The empirically determined amount required to successfully control melt foaming without significantly reducing the glass melt was found to correspond to a ratio of 0.5 when any nitrites present were counted as nitrates (i.e., 0.75 moles of organic carbon per mole of nitrate + nitrite). This approach has been employed for all WTP melter testing. It is, however, expected that slight variations around the nominal value of 0.5 may be necessary to account for differences in the reducing power of waste organics in comparison to sugar, particularly for LAW streams that are high in organics.

As an example, the calculation of the amount of sugar needed for the present LAW Envelope A feed to achieve a sugar ratio of 0.5 proceeds as follows:

- One liter of 8 Molar sodium simulant contains 1.857 moles of nitrite and 2.048 moles of nitrate, giving a total of 3.905 moles of NOx (see Table 2.1)

- Required total amount of organic carbon for a sugar ratio of 0.5 is $3.905 \times 0.75=2.929$ moles

- One liter of simulant contains 0.174 moles of organic carbon (see Table 2.1)

- $\quad$ Therefore, $2.929-0.174=2.755$ moles of organic carbon must be added.

Since the molecular weight of sucrose is $342 \mathrm{~g}, 2.755 \times 342 / 12=78.5 \mathrm{~g}$ sugar must be added per liter of simulant, as shown in Table 2.13.

\subsection{Analysis of Feed Samples}

\subsubsection{General Properties}

Feed samples were analyzed from melter tests to confirm physical properties and chemical composition. Samples taken during melter testing were from an in-line sampling port. Sample names, sampling dates, measured properties and target values are given in Table 2.26 along with corresponding average measured values from previous tests with similar waste simulants [2, 3, 13, 49]. The melter feed samples have higher water contents and slightly lower densities and glass yields than the target values, due perhaps to high estimates in the purity of the additives as well as water added during the transfer of feed. The average measured glass yield for the melter samples, however, was less than $6 \%$ below the target value, validating the use of the target value for calculating glass production rates. The measured and target feed water contents for the current LAW Envelope A feed are higher than for samples from the previous tests [2, 3, 
The Catholic University of America Vitreous State Laboratory
LAW Envelope A and B Glass Formulations Testing

to Increase Waste Loading

Final Report, VSL-06R6900-1, Rev. 0

49] due to the higher waste loading and, therefore, higher proportion of aqueous waste in the feed. Measured and target values for feed properties from the current test are similar to samples from previous tests as a result of using the same simulant composition, the sodium molarity being selected to achieve similar rheological properties, and use of many of the same additives. The measured feed properties for the current LAW Sub-Envelope B2 samples are bracketed by those of samples from previous tests which varied the ratio of waste to glass forming additives, even though the current simulant is $4 \mathrm{M}$ sodium and the previous simulant was only $1.3 \mathrm{M}$ sodium. The measured $\mathrm{pH}$ values are similar for feed samples produced from the same waste Envelope (A or B) and much lower for the feed produced from the LAW Envelope B simulant due to the much lower hydroxide concentration in the more dilute waste stream (4 vs. 8 molar sodium) and the lower waste loading.

\subsubsection{Rheology}

Samples of the melter and crucible scale feeds that were used for these tests were also subjected to rheological characterization. The results from rheological characterization of a variety of other melter feeds and waste simulants, as well as the effects of a range of test variables, are described in detail in separate reports [42, 43]. Melter feeds were characterized using a Haake RS75 rheometer, which was equipped with either a Z40DIN or a FL22-SZ40 sensor. A typical set of measurements consists of identifying the flow characteristics of the slurry by measuring the shear stress on the slurry at controlled shear rates and temperatures. In these measurements, the shear rate values are preset and are increased stepwise from $0.01 \mathrm{~s}^{-1}$ to $200 \mathrm{~s}^{-1}$ (70 $\mathrm{s}^{-1}$ for FL22-SZ40) with a sufficient delay (typically 15 to 30 seconds) between steps to ensure that shear stress is allowed to fully relax and therefore is measured at equilibrium. This approach is somewhat different from the "flow curve" approach in which the shear rate is ramped up to some maximum value and then ramped back down to produce a hysteresis curve that is dependent on the selected ramp rate. The viscosity of the sample as a function of the shear rate is then calculated as the ratio of the shear stress to the shear rate. The yield stress data for the melter feeds were measured using a controlled-stress mode in which the torque on the rotor was slowly increased while the resulting deformation of the fluid was monitored. The discontinuity in the measured deformation-torque curve was identified as the yield stress. It should be noted that this direct measurement of the yield stress can be quite different from the value that is often reported as the yield stress, which is obtained by extrapolation of the shear stress-shear rate curve to zero shear rate. All of the measurements in this work were made at $25^{\circ} \mathrm{C}$; previous work [42], which examined a range of temperatures, showed a relatively weak effect of temperature.

Rheograms for the melter feed samples, which show the feed viscosity versus shear rate, are presented in Figure 2.14. Also included in Figure 2.14 are values measured for feed samples from recent DM100 tests using LAW simulants [2, 32]. Figure 2.15 shows an alternative presentation of the data as plots of the shear stress versus shear rate; also included are proposed WTP bounds for feed rheology [50]. Measured yield stress and viscosity at selected shear rates are given in Table 2.27. The feed produced from LAW Envelope B is initially more resistant to flow as stirring is applied, as illustrated by the higher yield stress values; however, at shear rates greater than 1/second, the feed becomes less viscous than the other feeds. The rheological 
ORP-56322, Rev. 0

The Catholic University of America Vitreous State Laboratory
LAW Envelope A and B Glass Formulations Testing

to Increase Waste Loading

Final Report, VSL-06R6900-1, Rev. 0

properties for all feed samples are well within the proposed WTP bounds and vary within a relatively narrow range. No difficulties were encountered in processing this feed.

\subsubsection{Chemical Composition}

The chemical compositions of the feed samples were determined by first making a glass from the feed sample via crucible melt. The glass was subsequently crushed and analyzed directly by XRF. The boron oxide target value was used for normalizing the XRF data since its concentration was not determined by XRF. The XRF-analyzed compositions of the feed samples are provided in Tables 2.28 and 2.29. Selected samples were also subjected to DCP analysis of solutions generated by microwave aided acid dissolution; the results are compared to those obtained by XRF in Table 2.30. The results generally corroborate the consistency of the feed composition and show good agreement with the target composition for the major components. Boron and lithium concentrations measured by DCP were within two and ten percent of the target, respectively, validating the use of the target value for normalizing the XRF data. Of the oxides with a target concentration of one percent or greater, only the XRF values for magnesium, vanadium, and zinc oxides for the LAWB99 composition and tin oxide from the LAW187 had deviations of greater than $10 \%$ from target. These deviations were also observed in the product glasses but were considerably smaller in magnitude (see Section 5.1). Deficits of measured magnesium oxide contents being greater in the feed samples and substantially less in the product glass have been observed in several previous studies [3, 4, 9, 10, 49, 51, 52]. The DCP measured values for vanadium, magnesium, and tin deviated from their respective target values significantly less than did the corresponding values measured by XRF, suggesting a potential analytical bias for these elements using the XRF [2, 7, 32]. Titanium oxide was measured in the feed samples from about a tenth to a quarter of a weight percent, even though it was not included in the target composition. Similar observations were made in previous tests with LAW melter feeds [9, $1013,16-18,32]$ due to its presence as a contaminant in the glass forming additives, most notably kyanite [2]. Volatile minor elements such as sulfur, iodine, and chlorine are, as expected, below target due to loss during crucible melting. The target sulfur concentration in the feed, which is important for determining sulfur retention in the glass, is verified from the simulant vendor's batching sheets. The additional amounts of sulfur added by the VSL are calculated, checked, and weighed out using calibrated balances. 
The Catholic University of America Vitreous State Laboratory
LAW Envelope A and B Glass Formulations Testing

to Increase Waste Loading

Final Report, VSL-06R6900-1, Rev. 0

\section{SECTION 3.0 DM10 SCOPING TESTS}

Melter tests were conducted on the DM10 with the LAW Envelope B and A simulants from $8 / 8 / 05$ to $8 / 12 / 05$ and $9 / 28 / 05$ to $10 / 2 / 05$, respectively, to screen sulfur concentrations at two glass temperatures for future use on the DM100-WV. These tests produced almost a third of a metric ton of glass from almost 700 kilograms of feed. The tests, listed in the order in which they were performed, were as follows:

- Test B1: Five nominally 14-hour feeding segments with LAW Envelope B simulants at a glass temperature of $1150^{\circ} \mathrm{C}$ with target $\mathrm{SO}_{3}$ concentrations of 1.0, 1.2, 1.4, 1.6 and 1.5 $\mathrm{wt} \%$ in the glass product (assuming total retention).

- Test B2: Two nominally 14-hour feeding segments with LAW Envelope B simulants at a glass temperature of $1175^{\circ} \mathrm{C}$ with target $\mathrm{SO}_{3}$ concentrations of 1.6 and $1.7 \mathrm{wt} \%$ in the glass product (assuming total retention).

- Test A1: Two nominally 15-hour feeding segments with LAW Envelope A simulants at a glass temperature of $1150^{\circ} \mathrm{C}$ with target $\mathrm{SO}_{3}$ concentrations of 1.0 and $1.2 \mathrm{wt} \%$ in the glass product (assuming total retention).

- Test A2: Three nominally 15-hour feeding segments with LAW Envelope A simulants at a glass temperature of $1175^{\circ} \mathrm{C}$ with target $\mathrm{SO}_{3}$ concentrations of $0.8,1.1$ and $1.05 \mathrm{wt} \%$ in the glass product (assuming total retention). The test conducted at $0.8 \mathrm{wt} \% \mathrm{SO}_{3}$ was intended to ensure the glass pool was not saturated with sulfur prior to determining the maximum amount of sulfur the glass can retain under the test conditions.

The principal objective of these tests was to determine, for both glass compositions and at two different glass temperatures, the maximum amount of sulfur that can be fed into the melter without forming secondary sulfate phases. Processing conditions, including bubbling rate adjusted to maintain the target production rate of $2250 \mathrm{~kg} / \mathrm{m}^{2} /$ day and a complete cold cap, mimicked those to be used on the DM100. Test segment durations of 14 to 15 hours were selected since, at the target glass production rate, this provided three melt pool turnovers ( $24 \mathrm{~kg}$ ) for each sulfur concentration. At the end of each test segment, dip samples were taken to detect the presence of separated sulfur phases on the glass pool surface. Sulfur concentrations were increased for each waste composition and glass temperature until separated sulfur phases were observed, indicating that the ability of the process to accommodate that feed sulfur content had been exceeded. Sugar was added to the feed at a stoichiometric carbon ratio of 0.5 for all of the DM10 tests. 


\subsection{DM10 System Description}

\subsubsection{Feed System}

The feed container is mounted on a load cell for weight monitoring and is stirred continuously except for periodic, momentary interruptions during which the weight is recorded. The material in the feed container is constantly recirculated, which provides additional mixing. The recirculation loop extends to the top of the melter where feed is diverted from the recirculation loop through a peristaltic pump into the melter through a Teflon-lined feed line and vertical water-cooled feed tube. A diverter valve permits direction of the feed stream either to the melter or to a sampling vessel.

\subsubsection{Melter}

The DM10 system used for this work is a ceramic refractory lined melter, which includes two Inconel 690 plate electrodes that are used for joule-heating of the glass pool and a bubbler for agitating the melt. Glass is discharged from the melter using an air-lift system. The melt pool has a surface area of $0.021 \mathrm{~m}^{2}$ and typically contains about $8 \mathrm{~kg}$ of glass. The plenum volume is 19.5 liters at the nominal glass level. Inconel 690 thermowells were custom fabricated and installed in the DM10 for the current tests. In previous tests, thermowells made from Inconel 601 experienced rapid corrosion [32].

\subsubsection{Off-Gas System}

For operational simplicity, the DM10 is equipped with a dry off-gas treatment system involving gas filtration operations only. Exhaust gases leave the melter plenum through a film cooler device that minimizes the formation of solid deposits. The film cooler air has constant flow rate and its temperature is thermostatically controlled. The geometry of the transition line (between the melter and the first filtration device) conforms to the requirements of the 40-CFR-60 air sampling techniques. Immediately downstream of the transition line are cyclonic filters followed by conventional pre-filters and HEPA filters. The temperature of the cyclonic filters is maintained above $150^{\circ} \mathrm{C}$ while the HEPAs are held above $100^{\circ} \mathrm{C}$ to prevent moisture condensation. The entire train of gas filtration operations is duplicated and each train is used alternately. An induced draft fan completes the system. The sampling location for gaseous species monitored by FTIR is immediately downstream of the draft fan.

\subsection{DM10 Test Results}

Tables 3.1 and 3.2 provide summaries of the DM10 tests including run times, the amount of sulfur in the feed, the amount of feed sulfur retained in the glass product, observations of secondary phases, and glass processing temperatures. A listing of all the glasses discharged plus sulfur and iodine contents determined by XRF analysis of each glass sample are given in Tables 
The Catholic University of America Vitreous State Laboratory
LAW Envelope A and B Glass Formulations Testing

to Increase Waste Loading

Final Report, VSL-06R6900-1, Rev. 0

3.3 and 3.4. Sulfur and iodine compositional trends over the course of the tests are depicted in Figures 3.1 - 3.4. A listing of all the dip glass samples taken (by dipping a metal rod into the melt pool) to detect any secondary phases on the melt pool surface is given in Table 3.5. The stack exhaust was analyzed for a variety of gaseous species using FTIR (see Section 6.2); no $\mathrm{SO}_{2}$ was detected in any of the tests and therefore no FTIR data are reported in this section.

Average test segment production rates were within $10 \%$ of the target rate except for the last test with the LAW Envelope A due to difficulties in maintaining an appropriate cold cap. Bubbling rates required to achieve the target rate decreased with increasing glass pool temperature, as expected. The target glass temperatures were achieved for all test segments except for those with LAW Envelope A waste targeting $1175^{\circ} \mathrm{C}$. Glass temperatures up to $20^{\circ} \mathrm{C}$ lower than the target occurred due to the high conductivity of the glass (in combination with the high glass production rate), which limited the amount of power that could be used with this particular melter system. This difficulty was not anticipated or encountered during DM100 testing.

Evaluation of glass pool and discharge samples provided a clear indication of the tolerance of the glass formulations to sulfur at both glass pool temperatures. Depictions of the target and measured sulfur contents are provided in Figures 3.1.a and 3.1.b for tests with LAW Envelope B and A waste compositions, respectively. During tests with the LAW Envelope B wastes at $1150^{\circ} \mathrm{C}$, the measured concentration of sulfur in the glass product steadily increased with increasing feed sulfur content until the concentration in the glass product reached about $1.4 \mathrm{wt} \% \mathrm{SO}_{3}$. Subsequently, further increases in sulfur feed content to $1.6 \mathrm{wt} \% \mathrm{SO}_{3}$ on a glass basis resulted in a separated sulfate phase on the glass pool surface, as indicated by secondary sulfur phases on the samples taken directly from the melt pool by dipping a rod into the melt pool. Increasing the glass pool temperature from $1150^{\circ} \mathrm{C}$ to $1175^{\circ} \mathrm{C}$ increased sulfur volatilization but did not noticeably increase the concentration of sulfur in the glass product as the sulfur content of the feed was increased. A sulfur feed content of $1.7 \mathrm{wt} \% \mathrm{SO}_{3}$ on a glass basis resulted in a secondary sulfate phase. During tests with the LAW Envelope A waste, the separated sulfur layers were obtained at lower sulfur feed concentrations due to the lower sulfur solubility in the LAWA187 glass. Separated sulfate was observed on the glass pool at a sulfur feed concentration of $1.1 \mathrm{wt} \% \mathrm{SO}_{3}$ on a glass basis at a processing temperature of $1175^{\circ} \mathrm{C}$ and therefore sulfur feed concentrations for use on the DM100 needed to be lower. The concentration of iodine in the discharge glass is shown in Figures 3.2.a and 3.2.b for tests with LAW Envelope $\mathrm{B}$ and $\mathrm{A}$ waste compositions, respectively. The amount of iodine in the product was relatively constant at about $0.03 \mathrm{wt} \%$ and was unaffected by either glass composition or temperature.

Many of the sulfur layers which formed on the glass pool surface were extensive. Several hours of melt pool bubbling, and in some instances water feeding, were required to rid the melt pool of secondary phases. An example of these secondary sulfate phases on the dip glass samples is shown in Figure 3.3. Notice the powdery yellow material adhering to the rod and interspersed throughout some of the glass, both of which are indicative of a sample taken from a melt pool with a sulfate layer on the surface. The melt surface immediately after sampling is shown in Figure 3.4. The sulfur layer is observed as a film of material on the glass surface which moves across the surface in response to bubbling. 


\subsection{Feed Sulfur Concentrations Selected from DM10 Tests}

Based on these tests, the sulfur content of the LAW Envelope B feed selected for the DM100 tests was 1.5 and $1.6 \mathrm{wt} \% \mathrm{SO}_{3}$ on a glass basis for the tests at $1150^{\circ} \mathrm{C}$ and $1175^{\circ} \mathrm{C}$, respectively. The sulfur content of the LAW Envelope A feed selected for the DM100 tests was 0.95 and $1.05 \mathrm{wt} \% \mathrm{SO}_{3}$ on a glass basis for the tests at $1150^{\circ} \mathrm{C}$ and $1175^{\circ} \mathrm{C}$, respectively. These concentrations were below feed levels that resulted in secondary phase formation in DM10 tests. 
The Catholic University of America Vitreous State Laboratory
LAW Envelope A and B Glass Formulations Testing

to Increase Waste Loading

Final Report, VSL-06R6900-1, Rev. 0

\section{SECTION 4.0 DM100 OPERATIONS}

Melter tests were conducted on the DM100-WV with the LAW Envelope B and A simulants from $9 / 19 / 05$ to $9 / 25 / 05$ and $10 / 5 / 05$ to $10 / 11 / 05$, respectively. These tests produced over three metric tons of glass from approximately six and a half metric tons of feed; the tests are summarized in Table 4.1. The tests were 288 hours in duration and were divided as follows:

- Test B3: LAWB99 composition with $1.5 \mathrm{wt} \% \mathrm{SO}_{3}$, glass temperature $1150^{\circ} \mathrm{C}$, bubbling adjusted to maintain a $2250 \mathrm{~kg} / \mathrm{m}^{2} /$ day steady state production rate.

- Test B4: LAWB99 composition with $1.6 \mathrm{wt} \% \mathrm{SO}_{3}$, glass temperature $1175^{\circ} \mathrm{C}$, $2750 \mathrm{~kg} / \mathrm{m}^{2} /$ day steady state production rate achieved from the average bubbling rate used in Test B3.

- Test A3: LAWA187 composition with 0.95 wt\% SO 3 , glass temperature $1150^{\circ} \mathrm{C}$, bubbling adjusted to maintain a $2250 \mathrm{~kg} / \mathrm{m}^{2} /$ day steady state production rate.

- Test A4: LAWA187 composition with 1.05 wt $\% \mathrm{SO}_{3}$, glass temperature $1175^{\circ} \mathrm{C}$, $2600 \mathrm{~kg} / \mathrm{m}^{2} /$ day steady state production rate achieved from the average bubbling rate used in Test A3.

The tests were successful in determining sulfur feed concentrations that could be processed without the formation of secondary phases for two different glass compositions at two different glass temperatures. No secondary phases were observed on any of the dip samples taken during or after any of the DM100 tests, indicating that no secondary sulfur phases were present on the glass surface. In approximately ten percent of the 5-gallon pails filled with discharged glass, isolated, tiny (approximately $3 \mathrm{~mm}$ in diameter) inclusions of separated sulfate phases were visible (see Section 5.2). These sulfate inclusions are believed to be residual material from previous tests migrating from openings in the melter discharge area and are therefore not a consequence of the conditions and glass compositions used in the current tests. The glass dip samples are the most reliable means of determining the capacity of the glass to retain sulfur without forming secondary phases. Based on this criterion, the sulfur feed concentrations used represent the amounts of feed sulfur that can be successfully processed in the two glass formulations at the two melt temperatures evaluated.

For comparison purposes, to the extent possible, attempts were made to replicate the melter configuration and operating conditions used for the corresponding tests conducted earlier [2-4, 32] and the previous LAW Sub-Envelope [9-18] tests. These conditions include a near-complete cold cap, which is between $80-95 \%$ melt surface coverage for the DM100, since a $100 \%$ cold cap tends to lead to "bridging" in smaller melters. Glass production rates calculated from feed consumption are depicted in Figures 4.1.a and 4.1.b. The target production rate of $2250 \mathrm{~kg} / \mathrm{m}^{2} /$ day was obtained and maintained throughout the majority of the first test with each composition once the cold cap was established. The bubbling rates used to achieve this production rate, 9.3 and $17 \mathrm{lpm}$, respectively, for tests with LAW B and A compositions at 
The Catholic University of America Vitreous State Laboratory
LAW Envelope A and B Glass Formulations Testing to Increase Waste Loading Final Report, VSL-06R6900-1, Rev. 0

$1150^{\circ} \mathrm{C}$, were held constant throughout the second test with each feed composition, and the feed rate adjusted to provide a near complete cold cap. The increase in glass temperature to $1175^{\circ} \mathrm{C}$ resulted in production rate increases to 2750 and $2600 \mathrm{~kg} / \mathrm{m}^{2} /$ day for LAWB99 and LAWA187, respectively. This 16 to $22 \%$ increase in production rate for a $25^{\circ} \mathrm{C}$ increase in glass pool temperature is slightly less than the increase observed previously [3] by increasing the glass pool $50^{\circ} \mathrm{C}$ from $1175^{\circ} \mathrm{C}$ to $1225^{\circ} \mathrm{C}$. The lower increase in rate per degree increase in melt pool temperature may be due in part to composition modifications made to the Envelope A glass to accommodate higher temperatures, which increased its viscosity, but may also be related to the difference in the sulfate contents. A $50 \%$ increase in production rate was observed in tests with LAW Envelope $\mathrm{C}$ simulants [32] in response to a $25^{\circ} \mathrm{C}$ increase in glass pool temperature although the rate was not sustained for more than 24 hours. A steady state production rate for the LAWA187 composition at $1175^{\circ} \mathrm{C}$ was not achieved until after about one day, suggesting that a steady state may have not been achieved in the short test with the Envelope $\mathrm{C}$ simulants. During the present tests, as is typically observed, production rates varied from the target at the onset of feeding while the cold cap became established; in addition, instantaneous rates varied by as much as $25 \%$ as a result of variable feed pulse sizes. No processing problems were observed and no interruptions were experienced due to feed system clogging.

The results of various operational measurements that were made during these tests are given in Table 4.2. Glass temperatures are shown in Figures 4.2.a and 4.2.b, plenum temperatures in Figures 4.3.a and 4.3.b, electrode temperatures in Figures 4.4.a and 4.4.b, melt pool bubbling in Figures 4.5.a and 4.5.b, and power supplied to the electrodes in both Figures 4.3 and 4.4. Bulk glass temperatures approximated the target glass temperatures of $1150^{\circ} \mathrm{C}$ and $1175^{\circ} \mathrm{C}$ for the respective tests. Glass temperatures near the top of the melt pool are not reliable indicators of bulk glass temperatures as a result of gradients near the cold cap. Plenum temperatures typically ranged within the 450 to $650^{\circ} \mathrm{C}$ target and were mostly between 500 to $600^{\circ} \mathrm{C}$. The increase in glass temperature did not noticeably affect the plenum temperature due to the maintenance of a complete cold cap throughout testing. One exception occurred at the beginning of the LAWA test conducted at $1175^{\circ} \mathrm{C}$ due to the difficulty of maintaining a complete cold cap. Electrode temperatures increased with increasing glass temperature in a manner similar to the previous tests with the LAWC100 composition [32]. The east electrode temperature was typically the same temperature as the bulk glass, and was $60^{\circ} \mathrm{C}$ and $220-230^{\circ} \mathrm{C}$ hotter than the west and bottom electrodes, respectively. An exception to this trend occurred during the tests with the LAWA187 composition as the west electrode temperatures rose to values comparable to the east electrode. The bottom electrode was not powered during these tests. Power supplied to the electrodes averaged about $26 \mathrm{~kW}$ in tests producing glass at $2250 \mathrm{~kg} / \mathrm{m}^{2} /$ day, despite the differences in the two glass compositions. In response to the increase in glass temperature and the associated increase in glass production rate to $2750 \mathrm{~kg} / \mathrm{m}^{2} /$ day, power demand increased to about $30 \mathrm{~kW}$ during the test with the LAWB99 composition. Power demand increased to almost $35 \mathrm{~kW}$ during the initial portion of the test with LAWA187 composition at $1175^{\circ} \mathrm{C}$ as the production rate climbed to $3500 \mathrm{~kg} / \mathrm{m}^{2} /$ day. Subsequently, as the production rate decreased to the final steady state rate of $2600 \mathrm{~kg} / \mathrm{m}^{2} /$ day, power demand dropped to about $28 \mathrm{~kW}$. Average bubbling rates of about 9 and $17 \mathrm{lpm}$ were required to obtain the target production rate of 2250 $\mathrm{kg} / \mathrm{m}^{2} /$ day during the initial test with the LAWB99 and LAWA187 compositions, respectively; per the Test Plan, these same bubbling rates were used during the second test with each 
The Catholic University of America Vitreous State Laboratory
LAW Envelope A and B Glass Formulations Testing

to Increase Waste Loading

Final Report, VSL-06R6900-1, Rev. 0

composition to determine the effect of glass temperature on production rate. The bubbling rate of $17 \mathrm{lpm}$ used with LAWA187 composition is the same as that used for the LAWC100 composition, highlighting the similarity between the two compositions and the differences with the LAWB99 composition. Glass production rates measured during the current tests, along with those measured during previous LAW Sub-Envelope A and B tests on the DM100 and LAW Pilot Melter, are compared in Section 7.

Several steps were taken to understand and limit the migration of glass into the discharge chamber observed in the previous tests [32]. The discharge chamber temperature was maintained between 850 and $900^{\circ} \mathrm{C}$, which largely stopped glass from migrating into the discharge chamber as observed in the previous test when the discharge was maintained at about $1000^{\circ} \mathrm{C}$ [32], without hampering the desired flow of glass by the air lift. After completion of the tests, the discharge chamber was removed and inspected to identify the glass migration pathway. No obvious pathways were observed; however, possible routes in between bricks directly behind the discharge trough were noted. The investigation continued by removal of the melter lid to permit examination of the melter bricks on the opposite side of the discharge chamber. An indentation about eight inches wide was observed at the glass level in the refractory wall containing the airlift. Probing with a metal rod indicated the cavity was about four inches high and about three inches deep. The cavity was probably created by erosion caused by the bubbler, perhaps as a result of mis-orientation for some period of time. The bubbler is situated in the corner of the melter adjacent to the discharge chamber pointing towards the melter center. Rotation of the bubbler can potentially result in the bubbler pointing instead towards the location of the cavity in the bricks. Separated sulfate often forms on the melt surface during idling periods when the glass temperature is reduced. Since the cavity in the bricks is at the glass surface, separated sulfur can readily be tapped off the pool surface towards the discharge chamber. Furthermore, since the cavity spans a seam in the bricks, there is a relatively short pathway through the wall for a low-viscosity fluid such as the molten sulfate. The tests with the LAWC100 glass followed a 10month idling period which would have allowed significant migration into the crevasses between bricks around the discharge chamber. Future operating conditions of the melter will include a low discharge chamber temperature and low glass level to limit migration through the cavity in the bricks until such time as repairs can be effected.

The gas temperature at the film cooler and transition line outlet averaged from 301 to $283^{\circ} \mathrm{C}$, depending on the plenum temperature as well as the amount and temperature of the added film cooler air. Little drop in gas temperature was observed across the (insulated) transition line, which serves to prevent condensation, as intended. 
The Catholic University of America Vitreous State Laboratory
LAW Envelope A and B Glass Formulations Testing

to Increase Waste Loading

Final Report, VSL-06R6900-1, Rev. 0

\section{SECTION 5.0 DM100 GLASS PRODUCTS}

Over three metric tons of glass was produced in these tests. The glass was discharged from the melter periodically into 5-gallon carbon steel pails using an airlift system. The discharged product glass was sampled at the end of each test by removing sufficient glass from the top of the cans for total inorganic analysis. Care was exercised during sampling of each pail to segregate any secondary phases that were observed; these constituted less than a hundredth of a weight percent of the glass in any one pail. In the vast majority of the pails no secondary phases were observed. Additional samples were taken from the end of each test and sealed in containers for shipment to ORP, as required by the Test Plan. Product glass masses, discharge date, analysis performed, and observations of secondary phases are listed in Tables 5.1 and 5.2. Glass samples were also obtained by dipping a rod into the glass pool at the beginning and end of each test. These "dip samples" underwent visual examinations to detect the presence of a separate sulfate phase on the glass pool surface.

\subsection{Compositional Analysis}

Glass discharge samples were crushed and analyzed directly by XRF. No visible secondary phases were included in the samples used for compositional analysis. The target values for boron and lithium oxides, which are not determined by XRF, were used for normalizing the XRF data to $100 \mathrm{wt} \%$. The XRF-analyzed compositions of all discharged glass samples are provided in Tables 5.3 and 5.4 and, for selected samples, are compared with the results of DCP analysis of solutions generated by microwave aided acid dissolution in Table 5.5. The majority of the XRF analysis results compared very favorably to their corresponding target values. During tests with the LAWB99 composition, the only oxides with a target concentration of one percent or more to deviate from target by more than ten relative percent were vanadium oxide in both test segments, and iron during the initial test segment. All oxides in the LAWA187 composition with target concentrations greater than one percent deviated by less than ten percent from the target. Measured boron and lithium concentrations were within three percent of the target, validating the use of the target value for normalizing the XRF data. Agreement between the two analytical methods was excellent, except for low sodium and calcium values obtained from the DCP analysis, which is due in part to a low-bias for sodium; previous experience indicates that the XRF results are more reliable in this regard. Another comparison of note is the lower vanadium concentrations measured by DCP, supporting the notion of a small, but consistently high, bias for vanadium using the XRF method.

Compositional trends of the major and select oxides during the tests shown in Figures 5.1 - 5.6 illustrate the closeness to target and the consistency of composition over the course of the tests. Major changes during the initial portion of the first test, as the melt pool was turned over from a LAW Envelope A composition [53] to the LAWB99 composition, are observed as increases in aluminum, calcium, and vanadium at the expense of sodium, iron, 
The Catholic University of America Vitreous State Laboratory
LAW Envelope A and B Glass Formulations Testing

to Increase Waste Loading

Final Report, VSL-06R6900-1, Rev. 0

titanium, and potassium. As the melt pool transitioned from the LAWB99 composition to the LAWA187 composition, the intended increases in sodium, chromium, and tin are observed at the expense of calcium, lithium, and silicon. The concentration of iron in the WTP LAW Envelope A glass [53] was about five times higher than the LAWB99 target and, therefore, three melt pool turnovers were not sufficient to reduce the iron concentration to the target value, as shown in Figure 5.5. Also apparent in Figure 5.5 is the approximately $0.25 \mathrm{wt} \%$ of titanium oxide present in the glass due to contamination of additives, as well as the additional potassium in the product also originating probably as contaminant in the additives or the chemicals used to make the simulant. Chromium is also above the target concentration, as shown in Figure 5.6, due to leaching from the melter refractories and Inconel components, which are high in chromium. Changes in glass temperature had no discernable effect on the concentration of these oxides in the discharged product during tests with either glass composition.

Particular attention was paid to the behavior of volatile feed components such as sulfur and halides during these tests. Measured concentrations of iodine, chlorine, and sulfur in the glass product are compared to their respective target concentrations in Figures 5.6 - 5.10. Iodine feed concentrations were constant throughout the tests at $0.1 \mathrm{wt} \%$ on a glass basis, whereas the sulfur concentration was manipulated throughout the tests to determine the maximum incorporation amount without secondary phase formation. Chlorine was present in measurable quantities only in the LAWA187 glass. Iodine concentrations in the product glasses were relatively constant at around $0.03 \mathrm{wt} \%$ throughout the tests with the LAW Envelope B simulants, which is a little higher than the $0.02 \mathrm{wt} \%$ measured during the tests with the same feed on the DM10 (see Figure 3.2.a). Both of these results are in contrast to previous tests with lower alkali ( $<18$ wt $\% \mathrm{Na}_{2} \mathrm{O}$ ) glasses and feed containing nominal concentrations of reductants, which produced glass with no measurable retention of iodine in the product glass [12, 13, 15-17]. The higher iodine retention observed in the current tests may be related to the presence of vanadium, which was used as an additive. While processing the high alkali LAWA187 composition, iodine retention in the glass averaged about $0.03 \mathrm{wt} \%$ throughout the DM10 tests as well as both steady state portions of the DM100 tests. Iodine concentrations were higher during the initial portion of the second test with LAWA187 when the feed rate was higher, suggesting a kinetic effect. After the melt pool was turned over to the LAWA187 composition, chlorine concentrations in the product glasses were constant at about $50 \%$ of the feed concentration, consistent with previous melter tests using high chlorine content feeds [2-4, 15-17, 32, 53]. From the perspective of incorporation into the glass melt, chlorine is not as volatile as iodine, but is considerably more volatile than sulfur, as evidenced by concentrations showing wider deviations from the target. Steady-state concentrations of $\mathrm{SO}_{3}$ were attained during each DM100 test segment, as evidenced by the plateau in sulfate concentrations observed during each segment, and the lack of formation of secondary sulfate phases on the surface of the glass pool. Concentrations of $\mathrm{SO}_{3}$ in the product glasses were lower in glasses produced in the DM100 than the DM10 for comparable feed sulfur contents. Higher sulfur feed concentrations in the DM100 feed will, therefore, be required to reach the steady state sulfur concentrations observed in the DM10 tests due to the higher rate of sulfur volatilization on the DM100. The concentration of these volatile components was largely unaffected by the $25^{\circ} \mathrm{C}$ change in glass temperature. 
The Catholic University of America

Vitreous State Laboratory
LAW Envelope A and B Glass Formulations Testing

to Increase Waste Loading

Final Report, VSL-06R6900-1, Rev. 0

\subsection{Secondary Phase Observations}

All discharged glass and glass "dip" samples taken directly from the melt pool were closely examined to document the presence or absence of secondary phases. Glass dip samples were obtained at the beginning and end of each test to ascertain whether a secondary sulfate layer had formed on the surface of the glass melt. Table 5.6 provides a listing of all of the dip samples and whether or not a separate salt phase was evident. All dip samples taken in the middle and end of the four DM100 tests indicated that there was no secondary sulfate on the glass melt surface. Less than seven percent and fourteen percent, respectively, of the 5-gallon pails filled with glass from the LAW Envelope B and A tests had visible secondary sulfur phases. They were observed as very tiny (approximately $3 \mathrm{~mm}$ in diameter) isolated inclusions with no obvious correlation to glass temperature and sulfur concentration. Accordingly, these are thought to be due to mechanical incorporation due to migration through the discharge chamber. Many of the inclusions were observed in pails at the onset of testing. No large swirls of sulfate were observed on the surface of any of the glass from these tests in contrast to the previous test with LAWC100 glass [32]. This can be attributed in part to maintaining a significantly lower discharge chamber temperature which limited the migration of material through the cavity and seam in the melter refractories.

\subsection{Comparison of PCT and VHT of Crucible and Melter Glasses}

The results of PCT and VHT procedures on glass samples from DM100 melter tests and crucible glass samples of the same composition are presented in Tables 5.7 and 5.9 for Envelope A glass LAWA187 and Envelope B glass LAWB99, respectively. The results are compared and discussed in the following sections.

\subsubsection{Comparison of PCT and VHT of Envelope A Crucible and Melter Glasses}

The results of PCT and VHT procedures on the Envelope A crucible and melter glass samples are given in Table 5.7. Target and analyzed compositions of the crucible and melter glasses are given in Tables 2.2 and 5.4, respectively. The target and analyzed compositions of the crucible and melter glasses are similar, with the only notable difference being the measured $\mathrm{Na}_{2} \mathrm{O}$ concentration in the melter sample EWV-G-108B of $21.10 \mathrm{wt} \%$, compared to a target of $22.91 \mathrm{wt} \%$; the majority of the melter samples and the steady-state average are in much closer agreement with the crucible melt composition. Both crucible and melter "as-melted" samples, and those heat treated according to canister centerline cooling (CCC) were subjected to PCT. The "as-melted" crucible glass sample LAWA187 showed higher PCT responses than the other three samples (crucible as-melted, melter as-melted, and melter CCC). The PCT values show \%RSD values comparable to those from PCT round-robin testing of an Argonne National Laboratory - Low-Activity Waste Reference Material (ANL-LRM) glass [54] when the results of all four samples are considered. The \%RSD values are much lower $(<7 \%)$ if the PCT results of the "as-melted" crucible glass sample are excluded. 
The Catholic University of America Vitreous State Laboratory
LAW Envelope A and B Glass Formulations Testing

to Increase Waste Loading

Final Report, VSL-06R6900-1, Rev. 0

VHT results of eight LAW Envelope A glasses are given in Table 5.7. Duplicate measurements were conducted on the "as-melted" crucible glasses, which show good agreement with VHT alteration rates of 25 and $33 \mathrm{~g} / \mathrm{m}^{2} /$ day. EWV-G-89B is a melter discharge sample from the end of the DM100 test at $1150^{\circ} \mathrm{C}$. Both the "as-melted" sample and one subjected to CCC heat treatment were tested, with the "as-melted" sample being tested in duplicate. Duplicate samples of the "as-melted" EWV-G-89B showed VHT alteration rates of 81 and $90 \mathrm{~g} / \mathrm{m}^{2} /$ day, both above the contract limit of $50 \mathrm{~g} / \mathrm{m}^{2} /$ day, whereas the EWV-G-89B sample subjected to CCC heat treatment showed a VHT alteration rate of $23 \mathrm{~g} / \mathrm{m}^{2} /$ day, which is comparable to the results of LAWA187 crucible samples. Similar results were obtained for EWV-G-93B melter glass, which is a sample from the beginning of the DM100 Envelope A melter test at $1175^{\circ} \mathrm{C}$, with the "as-melted" sample showing a VHT alteration rate of $71 \mathrm{~g} / \mathrm{m}^{2} /$ day and the CCC heat treated sample $22 \mathrm{~g} / \mathrm{m}^{2} /$ day. The "as-melted" sample of EWV-G-108B, a sample from part way into the DM100 melter run at $1175^{\circ} \mathrm{C}$, showed a VHT alteration rate of $29 \mathrm{~g} / \mathrm{m}^{2} /$ day. Examination of the three "as-melted" melter glass samples that exceeded the VHT limit showed extensive cracking in the coupons, exposing more surface area for reaction. This type of cracking was not observed in the other samples with lower VHT alteration rates. To ensure that the sample preparation and CCC heat treatment did not substantially alter the glass composition, the composition of one of the melter glass samples subjected to CCC heat treatment was determined by XRF and is given in Table 5.8. As is evident from the table, there is little difference in the composition of the sample before and after CCC heat treatment. The main difference between the samples that exceeded VHT alteration rate of $50 \mathrm{~g} / \mathrm{m}^{2} /$ day and those that did not, is the cracking observed in the coupons with high alteration rates. Another difference is that in the samples with high alteration rates, a combination of cracking and glass reactions with the vapor phase changed the dimensions of the sample such that the sum of the dimensions of the altered layer and the remaining unreacted glass do not equal that of the original sample. The reason for the cracking observed in some VHT coupons, and not in others, has not been identified. However, it is possible that the more rapidly cooled (as-melted) melter samples are subject to thermal stresses that are relaxed during the prototypical CCC heat treatment. In general, however, it appears from previous tests that higher alkali glasses tend to be more prone to cracking in the VHT. VHT alteration rates for all the samples that did not show cracking of the VHT coupons are comparable, and less than the contract limit of $50 \mathrm{~g} / \mathrm{m}^{2} /$ day.

\subsubsection{Comparison of PCT and VHT of Envelope B Crucible and Melter Glasses}

The results of the PCT and VHT procedures on the Envelope B crucible glass LAWB99 and a melter glass from the end of the $1150^{\circ} \mathrm{C}$ DM100 melter test, DWV-G-123C, are given in Table 5.9. The target and analyzed compositions of the crucible and melter glasses are given in Tables 2.16 and 5.3, respectively. As is evident from the tables, both the target and analyzed compositions of the crucible and melter glasses are similar. The only significant difference is the $\mathrm{SO}_{3}$ concentration, with the crucible glass having target and analyzed concentrations of 0.75 and $0.64 \mathrm{wt} \%$, respectively, and the melter glass having higher target and analyzed concentrations of 1.5 and $1.17 \mathrm{wt} \%$, respectively. The VHT alteration rates for the crucible and melter glasses are 15 and $22 \mathrm{~g} / \mathrm{m}^{2} /$ day, respectively, showing reasonable agreement with each other, and well below 
The Catholic University of America Vitreous State Laboratory
LAW Envelope A and B Glass Formulations Testing

to Increase Waste Loading

Final Report, VSL-06R6900-1, Rev. 0

the contract limit of $50 \mathrm{~g} / \mathrm{m}^{2} /$ day [46]. The percent relative standard deviation (\%RSD) of the VHT values is about $27 \%$, which is smaller than the \%RSD of $43 \%$ from replicate VHT measurements on LAW glasses [45].

PCT responses (normalized mass loss in $\mathrm{g} / \mathrm{m}^{2}$ ) for the DWV-G-123C melter glass are $0.09,0.17$, and 0.06 for $\mathrm{B}, \mathrm{Na}$ and $\mathrm{Si}$, respectively. PCT responses for the crucible melt sample LAWB99 are $0.12,0.21$, and 0.07 for $\mathrm{B}, \mathrm{Na}$, and $\mathrm{Si}$, respectively. Thus, the PCT responses for the crucible and melter glass samples are comparable, and both are well below the contract limit for normalized mass loss of $2.0 \mathrm{~g} / \mathrm{m}^{2}$ for B, Na, and Si [46]. The \%RSD in PCT responses for the crucible and melter glass samples of $20 \%, 15 \%$, and $11 \%$ for $\mathrm{B}$, $\mathrm{Na}$, and $\mathrm{Si}$, respectively, are smaller than the $\%$ RSD values of $27 \%, 21 \%$, and $15 \%$ for B, Na, and Si, respectively, from PCT round-robin testing of an ANL-LRM glass [54]. 
The Catholic University of America

Vitreous State Laboratory
LAW Envelope A and B Glass Formulations Testing

to Increase Waste Loading

Final Report, VSL-06R6900-1, Rev. 0

\section{SECTION 6.0 \\ MONITORED OFF-GAS EMISSIONS}

\subsection{Particulate Sampling}

The melter exhaust was sampled for metals/particles according to 40-CFR-60 Methods 3, 5, and 29 at steady-state operating conditions during each DM100 test. The concentrations of off-gas species that are present as particulates and gaseous species that are collected in impinger solutions were derived from laboratory data on solutions extracted from air samples (filters and various solutions) together with measurements of the volume of air sampled. Particulate collection required isokinetic sampling, which entails removing gas from the exhaust at the same velocity that the air is flowing in the duct (40-CFR-60, Methods 1-5). Typically, a sample size of 30 dscf was taken at a rate of between 0.5 and 0.75 dscfm. Total particulate loading was determined by combining gravimetric analysis of the standard particle filter and chemical analysis of probe rinse solutions. An additional impinger containing $2 \mathrm{~N} \mathrm{NaOH}$ was added to the sampling train to ensure complete scrubbing of acid gases, particularly halogens. The collected materials were analyzed using direct current plasma atomic emission spectroscopy (DCP-AES) for the majority of the constituents and ion chromatography (IC) for anions. Melter emission fluxes are compared to feed fluxes in Tables 6.1 and 6.2 where the distinction is made between constituents sampled as particles and as "gas". The "gaseous" constituents are operationally defined as those species that are scrubbed in the impinger solutions after the air stream has passed through a $0.3 \mu \mathrm{m}$ heated filter. All samples were within $10 \%$ of isokinetic.

Particulate emission rates as a percentage of feed for tests conducted at $1150^{\circ} \mathrm{C}$ and $1175^{\circ} \mathrm{C}$ were very similar, suggesting that the effect of the $25^{\circ} \mathrm{C}$ increase is within the variability of the measurements. This finding corroborates observations from previous tests, which showed that increases in particulate material did not occur until the glass melt temperature exceeded $1200^{\circ} \mathrm{C}$ [3, 32]. Particulate emission rates were over an order of magnitude higher in the tests with the LAWA187 than the LAWB99 composition due to the much higher alkali metal and chlorine contents in the LAW Envelope A feed. This emission trend of increasing particulate emissions with increasing feed alkali content has been observed over a wide range of LAW waste compositions and melter platforms [7-18, 49, 51-53, 55, 56]. As expected, the feed elements with the lowest melter decontamination factors (DF) were halogens and sulfur, followed by chromium, alkali metals, vanadium, and boron. It should be noted, however, that the chromium values are likely biased high as a result of the prevalence of chromium-containing materials in the melter (K-3 and Inconel). Sulfur and chlorine emissions while processing the LAW187 composition were predominately particulate, which is consistent with previous studies using high-alkali LAW simulants [2-4, 7, 8, 26, 29, 49, 55]. Conversely, emissions of halides and sulfur while processing the LAWB99 composition were mostly gaseous, in keeping with previous tests with low-alkali LAW Envelope B simulants [12, 13, 17, 55, 56]. Iodine was almost exclusively detected in the basic impinger of the sampling train, suggesting that the emissions were mostly in the form of molecular iodine. Conversely, the other halides were measured only in the acidic impinger solutions, indicating that emissions were in the form of 
The Catholic University of America Vitreous State Laboratory
LAW Envelope A and B Glass Formulations Testing

to Increase Waste Loading

Final Report, VSL-06R6900-1, Rev. 0

$\mathrm{HCl}$ and HF. Boron, sulfur, and the halides were the only elements detected in the impinger solutions collected downstream of the heated particle filter in the sampling train, which constitutes the "gas" fraction of the melter emissions.

\subsection{Gases Monitored by FTIR}

Melter emissions were monitored in each test for a variety of gaseous components, most notably carbon monoxide, ammonia, sulfur dioxide and nitrogen species, by Fourier Transform Infra Red Spectroscopy (FTIR). The off-gas system temperature is maintained well above $100^{\circ} \mathrm{C}$ beyond the sampling port downstream of the HEPA filter to prevent analyte loss due to condensation prior to monitoring. A summary of the average and the range of concentrations monitored during each test are provided in Table 6.3. The concentrations of select monitored species are plotted in Figures 6.1 - 6.4. The large variations in the measured concentrations evident in these figures are a result of the pulsed feeding system and the dynamic nature of the cold cap. The analytes listed in the tables are those that were expected to be observed during the test, based on previous work; no other species were detected in the off-gas stream by FTIR. The most abundant nitrogen species monitored was NO, which is consistent with previous tests [2-4, 7-18, 32, 49 51-53, 55, 56] in which nitrates and nitrites were abundant in the feed. Measured concentrations of most monitored components increase with increasing feed rates while processing each of the two glass compositions. Nitrogen oxide, carbon monoxide, and ammonia concentrations are higher in tests with the feed containing the LAW Envelope A simulants as a result of the higher nitrate and, therefore, sugar concentrations in the feed. Conversely, sulfur concentrations are higher in LAW Envelope B simulants and therefore measured sulfur dioxide emissions are significantly higher in tests with those simulants. The FTIR detection limit for sulfur dioxide is relatively high (5 ppmv) and, therefore, measurable quantities are only observed with high sulfur containing feeds and in systems with minimal dilution of the melter exhaust by film cooler or process air. Water concentrations measured in the melter exhaust provided in Tables 6.1 and 6.2 are approximately two and one quarter times higher than those measured by FTIR as a result of dilution by an induced draft fan upstream of the FTIR monitoring point. Data collected on the DM100 and DM10 systems are consistent for each feed type; however, the process air dilution factor is much higher for the DM10 system.

The results of a nitrogen mass balance are summarized in Table 6.4. In keeping with previous tests with feed at a sugar ratio of 0.5 [2-4, 7-18, 32, 49, 51-53, 55, 56], about 50\% of the feed nitrogen oxides was reduced to diatomic nitrogen.

\subsection{Mass Balance for Volatile Constituents}

Table 6.5 provides the percentages of sulfur, chlorine, and iodine that were retained in the glass product or identified in the various off-gas stream samples for the DM100 tests. Data for other similar DM100 tests processing LAW simulants are included for comparison. The sulfur mass balance around the melter was good for all four tests, with totals ranging from 88 - 95\%. Sulfur retention in the glass ranged between 72 and 81\%, depending on the composition of the 
The Catholic University of America Vitreous State Laboratory
LAW Envelope A and B Glass Formulations Testing

to Increase Waste Loading

Final Report, VSL-06R6900-1, Rev. 0

target glass, particularly sulfur. Between two-thirds to three-quarters of feed sulfur for compositions produced from the low sodium LAW Envelope B simulants was retained in the glass product. Retention is typically higher in compositions produced from LAW Envelope A simulants which are high in sodium, and that was also the case for the present tests. However, despite the increase in sodium content (23 wt\% vs. $20 \mathrm{wt} \%$ ), sulfur retention in the current test with LAW Envelope A simulants was towards the low end of the range observed in previous Envelope A tests. The observed lower sulfur retention may be due to the high concentration of sulfur in the feed or the use of vanadium as an additive, which in a past test (at higher concentration) resulted in lower sulfur retention [4]. Emissions of sulfur were mostly in the form of particles for the tests with LAW A simulants, and mostly in the form of a gas in tests with LAW B simulants. Mass balance closure for chlorine was also good for the tests with the LAWA187 composition at 89 - 97\%; however, this was not reported for the tests with LAWB99 due to the very low feed chlorine concentrations. About half the chlorine was retained in the glass, with the other half emitted from the melter as particles, in keeping with results from previous tests. Mass balance closure for iodine was excellent, with three of the four tests within $5 \%$ of total recovery. Iodine retention in the glass was relatively constant throughout the DM100 tests at about 30\%. This was anticipated for the tests with the high alkali LAWA187 composition but not for the lower alkali LAWB99 composition. Notice in Table 6.5 that previous tests with LAW B simulants, which had even lower alkali contents than did the present Envelope B formulation, resulted in no iodine retention in the glass. In addition to the higher alkali content, a further difference in the current glass produced from LAW Envelope B simulants is the inclusion of vanadium in the glass formulation, which may also increase iodine incorporation into the glass product. In keeping with numerous previous tests, the iodine that was lost from the melt pool and cold cap was volatilized as a gas rather than as particulate.

As stated above, the data given in Table 6.5 show good mass balance closure for the volatile components from the current tests and previous DM100 tests using LAW feeds. The glass sulfur, iodine, and chlorine retention values are averages from analyses of multiple glass samples over the course of the tests. Particle and gaseous emissions values given in Table 6.5 are the results obtained from discrete samples collected over small time periods of the tests. The emission values, therefore, are likely to have more variability than the glass retention values because of changes in the melter, cold cap, and off-gas conditions during the test. 
The Catholic University of America Vitreous State Laboratory
LAW Envelope A and B Glass Formulations Testing

to Increase Waste Loading

Final Report, VSL-06R6900-1, Rev. 0

\section{SECTION 7.0 \\ COMPARISON OF TEST RESULS FOR “OLD” AND “NEW” FORMULATIONS}

This section provides a summary level comparison of the test results obtained with the optimized LAW Envelope A and B glass formulations that were developed in this work and corresponding data for select WTP baseline glass formulations.

The composition of the new Envelope A glass composition, LAWA187, is compared to compositions of two old LAW Envelope A glasses in Table 7.1. Compared to the old glasses, LAWA187 has lower $\mathrm{Fe}_{2} \mathrm{O}_{3}$ and $\mathrm{SiO}_{2}$ contents and higher $\mathrm{Al}_{2} \mathrm{O}_{3}$ and $\mathrm{B}_{2} \mathrm{O}_{3}$ contents. LAWA187 contains about $1 \mathrm{wt} \%$ each of $\mathrm{SnO}_{2}$ and $\mathrm{V}_{2} \mathrm{O}_{5}$, which are not present in the old glasses. $\mathrm{CaO}$, which is beneficial in improving sulfate solubility, was added to LAWA187 in higher concentration as compared to the old glasses. However, $\mathrm{Li}_{2} \mathrm{O}$, another component that is highly beneficial in improving sulfate solubility in the glasses, was not added to LAWA187 because of the already high alkali content from incorporation of about $23 \mathrm{wt} \%$ of $\mathrm{Na}_{2} \mathrm{O}$ from the LAW waste stream. LAWA187 has higher PCT response, and somewhat higher VHT response than the old Envelope A glasses, due mainly to its higher alkali (sodium) content. In combination, the composition changes (particularly the higher calcium, inclusion of vanadium, higher boron, lower silicon, and lower iron) lead to increased sulfur solubility, increased incorporation rate, and reduced tendency to form a separate sulfate phase during processing. Addition of $\mathrm{SnO}_{2}$ allows higher $\mathrm{Na}_{2} \mathrm{O}$ loading without large increase in the VHT alteration rate. The higher sulfate and sodium loadings allow higher waste loading, which results in about $23 \mathrm{wt} \% \mathrm{Na}_{2} \mathrm{O}$ in LAWA187 glass as compared to about $20.6 \mathrm{wt} \%$ or less $\mathrm{Na}_{2} \mathrm{O}$ in the old LAW Envelope A glasses.

The composition of the new glass Envelope B composition, LAWB99, is compared to compositions of two old LAW Envelope B glasses in Table 7.2. The old glasses, LAWB83 for AZ-101 and LAWB96 for AZ-102, have similar compositions, but different waste loadings. All of the $\mathrm{Na}_{2} \mathrm{O}$ in LAWB83 comes from the waste, whereas part of the $\mathrm{Na}_{2} \mathrm{O}$ in LAWB96 is added as a glass former. Compared to the old glasses, LAWB99 has lower $\mathrm{Fe}_{2} \mathrm{O}_{3}$ and $\mathrm{SiO}_{2}$ contents and higher $\mathrm{Al}_{2} \mathrm{O}_{3}$ content. LAWB99 contains about $1 \mathrm{wt} \%$ of $\mathrm{V}_{2} \mathrm{O}_{5}$, which is not present in the old glasses. $\mathrm{CaO}$, which is beneficial in improving sulfate solubility, was increased in concentration in LAWB99. $\mathrm{Li}_{2} \mathrm{O}$, another component that is highly beneficial in improving sulfate solubility in the glasses, was maintained at a high concentration in LAWB99. The $\mathrm{Li}_{2} \mathrm{O}$ concentration in LAWB99, however, is lower than in the old Envelope B glasses because LAWB99, due to its higher waste loading, contains about $10 \mathrm{wt} \% \mathrm{Na}_{2} \mathrm{O}$ as compared to about $5.5 \mathrm{wt} \% \mathrm{Na}_{2} \mathrm{O}$ in the old glasses. The viscosity and electrical conductivity of LAWB99 and the old LAW Envelope B glasses are similar. LAWB99 shows higher PCT and VHT values due to these compositional differences, including the higher $\mathrm{Na}_{2} \mathrm{O}$ concentration. In combination, the composition changes (particularly the higher calcium, inclusion of vanadium, lower silicon, and lower iron) lead to increased sulfur solubility, increased incorporation rate, and reduced tendency to form a separate 
The Catholic University of America Vitreous State Laboratory
LAW Envelope A and B Glass Formulations Testing

to Increase Waste Loading

Final Report, VSL-06R6900-1, Rev. 0

sulfate phase during processing. The higher sulfate loading allows higher waste loading, which results in about $10 \mathrm{wt} \% \mathrm{Na}_{2} \mathrm{O}$ in LAWB99 glass, as compared to about $5.5 \mathrm{wt} \% \mathrm{Na}_{2} \mathrm{O}$ in the old LAW Envelope B glasses.

Glass production rates measured during the current tests, along with those measured during previous LAW Envelope A and B tests on the DM100 and LAW Pilot Melter, are given in Tables 7.1 and 7.2, respectively. The bubbling rates for the DM100 test are also given in the Tables. All LAW Pilot Melter tests were conducted at a bubbling rate of about $170 \mathrm{lpm}$ $\left(51.5 \mathrm{lpm} / \mathrm{m}^{2}\right)$. The two LAW Envelope B feeds were processed in the DM100 at similar rates, even though the bubbling rate needed was lower for the new feed. The two old LAW Envelope B feeds processed in the LAW Pilot Melter at rates of 2.2 and $1.88 \mathrm{MT} / \mathrm{m}^{2} /$ day of glass. The two old LAW Envelope A feeds processed in the DM100 at a rate of about $1.98 \mathrm{MT} / \mathrm{m}^{2} /$ day of glass, whereas the new feed processed at a rate of about $2.14 \mathrm{MT} / \mathrm{m}^{2} /$ day of glass. The bubbling rate for the new feed and one of the old feeds was similar, whereas the other old feed needed a much lower bubbling rate. The DM100 can be used to determine differences in the processing rates of different feed formulations and the effect of variables, such as temperature, on processing rates when the relevant tests are conducted sequentially over a short time period. Since the DM100 has only one bubbler, the age of the bubbler, or small differences in the bubbler orientation can occasionally result in differences in the bubbling rate required to achieve a target glass production rate, and it becomes difficult to determine the exact reason for these differences, especially when the tests are conducted over a long period of time. Therefore, in this case, it is better to use the LAW Pilot Melter data to predict the glass production rate for the WTP melter while processing the LAW Envelope A and B feeds. Based on the LAW Pilot Melter data [22, 24, 30], at an operating temperature of $1150^{\circ} \mathrm{C}$, we would expect the new LAW Envelope B feed to process at a rate of about 19 to 22 MT of glass per day per WTP LAW melter, and the new LAW Envelope A feed to process at a rate of about 20 to 21 MT of glass per day.

Sulfur retentions in the LAWB99 and LAWA187 glasses during the present tests are compared to sulfur retentions in previous tests using LAW Envelope A and B feeds in Tables 7.1 and 7.2, respectively. The sulfur retentions were similar (71\% and $76 \%)$ for the old and new LAW Envelope B feeds. The sulfur retention of 81\% for the new LAW Envelope A formulation is somewhat lower than the retentions of $85 \%$ and $95 \%$ for two old LAW Envelope A formulations. This is probably due to the higher sulfur content of the new LAW Envelope A glass formulation. In previous tests, glass formulations with higher sulfur concentrations have, in general, shown lower sulfur retentions in the glass [57]. 
The Catholic University of America Vitreous State Laboratory
LAW Envelope A and B Glass Formulations Testing

to Increase Waste Loading

Final Report, VSL-06R6900-1, Rev. 0

\section{SECTION 8.0 SUMMARY AND CONCLUSIONS}

Several tests were conducted on the DM10 and DM100 vitrification systems to assess the effectiveness of new glass formulations for LAW Envelope A and B simulants in incorporating high levels of sulfur without the formation of secondary phases. Glass formulations selected for the melter tests were developed on the basis of a series of crucible melts that were prepared and characterized. The results of those tests led to the selection of LAWA187 and LAWB99 formulations, which contain $23 \mathrm{wt} \%$ and $10 \mathrm{wt} \% \mathrm{Na}_{2} \mathrm{O}$, respectively, and showed the potential for high sulfate incorporation. Both crucible glasses met all of the WTP product quality and processability requirements.

DM10 melter screening tests were conducted at two different glass temperatures, $1150^{\circ} \mathrm{C}$ and $1175^{\circ} \mathrm{C}$, to determine the maximum amount of feed sulfur that can be processed without forming secondary sulfate phases for both compositions. Based on these results, feed sulfur concentrations were selected for subsequent testing on the DM100 melter at temperatures of $1150^{\circ} \mathrm{C}$ and $1175^{\circ} \mathrm{C}$; the selected values were 0.95 and $1.05 \mathrm{wt} \% \mathrm{SO}_{3}$ for the $\mathrm{LAWA} 87$ composition, and 1.5 and $1.6 \mathrm{wt} \% \mathrm{SO}_{3}$ for the LAWB99 composition on a glass basis. No separated sulfur phases were observed on the melt pool surface during or at the end of any of the DM100 tests. Testing conducted with the LAW Envelope B feed was successful at retaining about three quarters of the feed sulfur in the glass product, yielding a glass with about $1.15 \mathrm{wt} \%$ $\mathrm{SO}_{3}$. The percent of feed sulfur retention in the LAWA187 glass was slightly higher, producing a product glass with about $0.8 \mathrm{wt} \% \mathrm{SO}_{3}$. Increases in glass temperature to $1175^{\circ} \mathrm{C}$ permitted an increase in feed sulfur concentration of $0.1 \mathrm{wt} \% \mathrm{SO}_{3}$ on a glass basis, although the increases in sulfur concentration in the glass product were minimal due to the higher rates of volatilization. A sample of the product glass from the end of the tests conducted at $1150^{\circ} \mathrm{C}$ for LAW Envelope B feed was subjected to the PCT and VHT procedures, which confirmed responses well below the respective WTP contract limits, as expected based on the PCT and VHT results for the corresponding crucible melt glass. A number of melter glasses from the $1150^{\circ} \mathrm{C}$ and $1175^{\circ} \mathrm{C}$ DM100 Envelope A test segments were subjected to PCT and VHT. As expected, the PCT responses of the melter samples were comparable to those of the corresponding crucible samples, and below the WTP contract limits. VHT results of two of the "as-melted" melter glass samples (including one duplicate) were over the contract limit, whereas three other samples (two CCC heat treated and one "as-melted") showed VHT alteration rates below the contract limit, and comparable to the results for the corresponding crucible glass. Examination of the VHT coupons with high alteration rates showed extensive cracking that increased the surface area exposed to the vapor phase for reactions. The reason for the cracking observed in some samples, and not in others, has not been identified, but may be related to thermal stresses that are relaxed during the prototypical CCC heat treatment. However, VHT alteration rates measured on samples that did not show cracking are all below the contract limit and compare well with the VHT results for the corresponding crucible glasses. 
The Catholic University of America Vitreous State Laboratory
LAW Envelope A and B Glass Formulations Testing

to Increase Waste Loading

Final Report, VSL-06R6900-1, Rev. 0

Total particulate and gaseous emissions from the melter were sampled for each DM100 test, permitting the determination of melter DFs for each element in the feed. Feed solids carry-over as particle emissions was more than an order of magnitude higher while processing LAW Envelope A wastes due to the much higher alkali and chlorine content. Good mass balance closure around the melter was achieved for sulfur, chlorine, and iodine. Iodine retention in the glass was about 30\% for both formulations. For the high-alkali Envelope A formulation, this is consistent with expectations based on previous tests, but is higher than expected for the lowalkali Envelope B formulation. Since a notable difference is the incorporation of vanadium in the present glass formulations, the role of vanadium on iodine retention would be worth further study.

The results of glass formulation development and DM100 melter tests showed that $\mathrm{SO}_{3}$ loadings in the feed of $0.95 \mathrm{wt} \%$ at $1150^{\circ} \mathrm{C}$, and $1.05 \mathrm{wt} \%$ at $1175^{\circ} \mathrm{C}$ are acceptable in an Envelope A feed containing $23 \mathrm{wt} \% \mathrm{Na}_{2} \mathrm{O}$ on a glass basis. Similarly, $\mathrm{SO}_{3}$ loadings in the feed of $1.5 \mathrm{wt} \%$ at $1150^{\circ} \mathrm{C}$ and $1.6 \mathrm{wt} \%$ at $1175^{\circ} \mathrm{C}$ are achievable in an Envelope B feed containing 10 wt $\% \mathrm{Na}_{2} \mathrm{O}$. In all cases, the results of DM100 tests showed that these feed sulfur contents were processable without the formation of a separate sulfate phase. In addition, increases in glass production rate of about $22 \%$ were achieved by increasing the glass pool temperature to $1175^{\circ} \mathrm{C}$.

In the work done for ORP by VSL and Duratek, new glass formulations with increased waste loadings have been developed for LAW Envelopes A, B and C waste streams. Since the new glass formulations have both higher $\mathrm{Na}_{2} \mathrm{O}$ and $\mathrm{SO}_{3}$ concentrations as compared to the WTP baseline glasses, and are based on slightly different simulant compositions and recycle assumptions, it is difficult to make a direct comparison of the waste loadings between these two. Instead, in the following section, the amount of glass to be produced at Hanford is calculated based on the WTP baseline and new ORP glass formulations. Compared to the baseline WTP LAW formulations, the new ORP formulations reduce the amount of LAW glass to be produced at Hanford by about $36 \%$.

\subsection{Impact on LAW Processing Rate and Glass Volume}

In the course of this work, glass formulations with enhanced waste loadings have been developed for Envelope A [2] and Envelope C [32] wastes. In the present work, those results were extended to increased sodium contents at high sulfur content for Envelope A. In addition, we have developed and demonstrated increased sulfur incorporation for Envelope B wastes, which tend to have relatively higher sulfur contents. While further work is necessary to extend this effort to cover the full range of sodium and sulfur contents that are needed to optimally process the Hanford LAW materials, the present data are now sufficiently extensive to permit quantitative estimates of the impact of these waste loading increases on the volume of LAW glass that is produced. Consequently, this section compares the glass volumes obtained for the new formulations with the volumes obtained for the present WTP baseline. In addition, the effects of increased temperature and increased melt surface area on increased melter throughput are also considered in order to assess the potential overall increase in waste treatment rate that is possible from the enhancements demonstrated in this program. 
The Catholic University of America Vitreous State Laboratory
LAW Envelope A and B Glass Formulations Testing

to Increase Waste Loading

Final Report, VSL-06R6900-1, Rev. 0

Data from the Tank Farm Contractor Operation and Utilization Plan (TF COUP) were used for the estimate of glass volumes. The sodium concentrations in the liquid fractions were increased by $17 \%$ to allow for sodium additions in WTP pretreatment. For the LAW material from each of the 177 tanks, the glass volume was calculated for the WTP baseline glass formulations and for the enhanced waste loading glass formulations developed in the present program. The results of the WTP baseline formulation work have been captured in an "LAW Correlation" [58], which was used to calculate the glass volume, and $\mathrm{Na}_{2} \mathrm{O}$ and $\mathrm{SO}_{3}$ loadings for each of the tanks. Similarly, the four glass formulations developed and tested in the present program (LAWA161 [2], LAWC100 [32], LAWA187, and LAWB99 (this work)) were applied to the LAW fraction from each of the 177 tanks in order to calculate the total glass volume.

The results of the above analysis, presented in Table 8.1, show that processing of the LAW fraction from all 177 tanks according to the WTP baseline would yield 588,000 MT of glass $\left(218,000 \mathrm{~m}^{3}\right)$. By employing the new formulations, the amount of glass would be reduced to $374,000 \mathrm{MT}\left(138,000 \mathrm{~m}^{3}\right)$, a reduction of $36 \%$. In addition, the average $\mathrm{Na}_{2} \mathrm{O}$ loading would be increased from $12.8 \mathrm{wt} \%$ for the WTP baseline to $20.2 \mathrm{wt} \%$ for the new formulations.

If the above reduction in glass volume is coupled with the increased processing rate of about $22 \%$ for a modest temperature increase of $25^{\circ} \mathrm{C}$, which has been validated at Pilot Melter scale [59], and the $47 \%$ increase in melt surface area for the WTP LAW melter that is possible with no impact to the external dimensions or geometry [60], the overall increase in LAW processing rate that is possible from these enhancements is about $180 \%$ (i.e., a $2.8 \times$ increase in throughput).

In conclusion, the present work has successfully demonstrated significant enhancements in sulfur tolerance, waste loading, and glass production rates that should lead to optimized utilization of the WTP LAW facility and overall reduction in LAW treatment cost and schedule. It should be noted that there is still room for yet further enhancements in the already significant improvements that have been demonstrated. In particular, the present enhanced scenario is limited by the set of only four base glass compositions, which cover a wide, but still limited, set of sodium to sulfur ratios. Naturally, therefore, further improvements are possible by expanding this set of compositions. In particular, the glass volume calculations of the type described above provide a means of identifying and prioritizing which additional compositions would have the greatest impact in terms of further reducing glass volumes. The highest priority in this respect would be placed on compositions like LAWA187, but in which the sodium content is further increased by somewhat relaxing the sulfate concentration requirement. Thus, an objective of subsequent work should be to strategically build on the base set of glass formulations developed in the present work in such a way that the overall glass volume can be minimized. 


\section{SECTION 9.0 REFERENCES}

[1] LAW Pilot Melter Decommissioning and Testing, Letter Subcontract \#DE-AC2703RV14539.

[2] "Glass Formulation Testing to Increase Sulfate Incorporation," K.S. Matlack, M. Chaudhuri, H. Gan, I.S. Muller, W. Gong, and I.L. Pegg, VSL-04R4960-1, Rev. 0, Vitreous State Laboratory, The Catholic University of America, Washington, DC, 2/28/05.

[3] "Small Scale Melter Testing to Assess Impact of Higher Temperature Melter Operations,” K.S. Matlack, W. Gong, and I.L. Pegg, VSL-04R4980-1, Rev. 0, Vitreous State Laboratory, The Catholic University of America, Washington, DC, 2/13/04.

[4] "Glass Formulation Testing to Increase Sulfate Volatilization from Melter," K.S. Matlack, W. Gong, and I.L. Pegg, VSL-04R4970-1, Rev. 0, Vitreous State Laboratory, The Catholic University of America, Washington, DC, 2/24/05.

[5] "Summary of Preliminary Results on Enhanced Sulfate Incorporation During Vitrification of LAW Feeds”, I.L. Pegg, H. Gan, I.S. Muller, D.A. McKeown, and K.S. Matlack, VSL-00R3630-1, Vitreous State Laboratory, The Catholic University of America, Washington, DC, 4/5/00.

[6] "Sulfur Incorporation in Waste Glass Melts of Various Compositions," W.K. Kot, H. Gan, and I.L. Pegg, Ceramic Transactions, Vol. 107, pp. 441, Eds. G.T. Chandler and X. Feng, American Ceramic Society, 2000.

[7] "Melter Tests with LAW Envelope B Simulants to Support Enhanced Sulfate Incorporation,” K.S. Matlack, S.P. Morgan, and I.L. Pegg, VSL-00R3501-1, Rev. 0, Vitreous State Laboratory, The Catholic University of America, Washington, D.C., $11 / 27 / 00$.

[8] "Melter Tests with LAW Envelope A and C Simulants to Support Enhanced Sulfate Incorporation,” K.S. Matlack, S.P. Morgan, and I.L. Pegg, VSL-01R3501-2, Rev. 0, Vitreous State Laboratory, The Catholic University of America, Washington, D.C., $1 / 26 / 01$.

[9] "Compositional Variation Tests on DuraMelter 100 with LAW Sub-Envelope A1 Feed (LAWA44 Glass) in Support of the LAW Pilot Melter,” K.S. Matlack, W. Gong, and I.L. Pegg, VSL-02R62N0-4, Rev. 0, Vitreous State Laboratory, The Catholic University of America, Washington, D.C., 6/18/02. 
The Catholic University of America Vitreous State Laboratory
LAW Envelope A and B Glass Formulations Testing

to Increase Waste Loading

Final Report, VSL-06R6900-1, Rev. 0

[10] "Compositional Variation Tests on DuraMelter 100 with LAW Sub-Envelope A2 Feed (LAWA88) Glass in Support of the LAW Pilot Melter,” K. S. Matlack, W. Gong and I.L. Pegg, VSL-02R62N0-3, Rev. 0, Vitreous State Laboratory, The Catholic University of America, Washington, D.C., 11/1/02.

[11] "Compositional Variation Tests on DuraMelter 100 with LAW Sub-Envelope A3 Feed in Support of the LAW Pilot Melter," K.S. Matlack, W. Gong, and I.L. Pegg, VSL01R62N0-1, Rev. 1, Vitreous State Laboratory, The Catholic University of America, Washington, D.C., 7/15/02.

[12] "Compositional Variation Tests on DuraMelter 100 with LAW Sub-Envelope B1 Feed in Support of the LAW Pilot Melter," K.S. Matlack, W. Gong, and I.L. Pegg, VSL02R62N0-5, Rev. 0, Vitreous State Laboratory, The Catholic University of America, Washington, D.C., 5/8/03.

[13] "Compositional Variation Tests on DuraMelter 100 with LAW Sub-Envelope B2 Feed in Support of the LAW Pilot Melter,” K.S. Matlack and I.L. Pegg, VSL-03R3410-2, Rev. 0, The Catholic University of America, Vitreous State Laboratory, Washington, D.C., 10/20/03.

[14] "Compositional Variation Tests on DuraMelter 100 with LAW Sub-Envelope C1 Feed (LAWC22 Glass) in Support of the LAW Pilot Melter,” K.S. Matlack, W. Gong, and I.L. Pegg, VSL-02R62N0-2, Rev. 1, Vitreous State Laboratory, The Catholic University of America, Washington, D.C., 9/23/02.

[15] “Compositional Variation Tests on DuraMelter 100 with LAW Sub-Envelope C2 Feed in Support of the LAW Pilot Melter,” K.S. Matlack, W. Gong, R.A. Callow and I.L. Pegg, VSL-04R4410-1, Rev. 0, Vitreous State Laboratory, The Catholic University of America, Washington, DC, 6/17/04.

[16] "DuraMelter 100 Sub-Envelope Changeover Testing Using LAW Sub-Envelope A1 and C1 Feeds in Support of the LAW Pilot Melter,” K.S. Matlack, W. Gong, and I.L. Pegg, VSL-02R62N0-6, Rev. 0, Vitreous State Laboratory, The Catholic University of America, Washington, D.C., 9/9/03.

[17] "DuraMelter 100 Sub-Envelope Changeover Testing Using LAW Sub-Envelope A2 and B1 Feeds in Support of the LAW Pilot Melter," K.S. Matlack, W. Gong, and I.L. Pegg, VSL-03R3410-1, Rev. 0, Vitreous State Laboratory, The Catholic University of America, Washington, D.C., 8/22/03.

[18] "DuraMelter 100 Sub-Envelope Changeover Testing Using LAW Sub-Envelope A3 and C2 Feeds in Support of the LAW Pilot Melter,” K.S. Matlack, W. Gong, and I.L. Pegg, VSL-03R3410-3, Rev. 0, Vitreous State Laboratory, The Catholic University of America, Washington, D.C., 10/17/03. 
[19] “RPP-WTP Pilot Melter Envelope B Throughput Test Results Report,” TRR-PLT-57, Duratek, Inc., Columbia, MD, 10/13/00.

[20] “RPP-WTP Pilot Melter Envelope A and C Throughput Test Results Report,” TRR-PLT54, Duratek, Inc., Columbia, MD, 10/13/00.

[21] “RPP-WTP Pilot Melter Sub-Envelope A1 Variation Test Results Report,” TRR-PLT071, Rev.0, Duratek, Inc., Columbia, MD, 4/28/03.

[22] “RPP-WTP Pilot Melter Sub-Envelope C1-A1 Changeover Test Results Report,” TRRPLT-035, Rev.0, Duratek, Inc., Columbia, MD, 9/29/03.

[23] “RPP-WTP Pilot Melter Sub-Envelope A2 Variation Test Results Report,” TRR-PLT070, Rev.0, Duratek, Inc., Columbia, MD, 10/4/02.

[24] "RPP-WTP Pilot Melter Sub-Envelope A2-B1 Changeover Test Results Report,” TRRPLT-078, Rev.0, Duratek, Inc., Columbia, MD, 11/3/03.

[25] “RPP-WTP Pilot Melter Sub-Envelope A3 Variation Test Results Report,” TRR-PLT060, Rev.2, Duratek, Inc., Columbia, MD, 11/19/02.

[26] “RPP-WTP Pilot Melter Sub-Envelope C2-A3 Changeover Test Results Report,” TRRPLT-079, Rev.0, Duratek, Inc., Columbia, MD, 11/11/03.

[27] “RPP-WTP Pilot Melter Sub-Envelope B1 Variation Test Results Report," TRR-PLT074, Rev.0, Duratek, Inc., Columbia, MD, 8/26/03.

[28] “RPP-WTP Pilot Melter Sub-Envelope B2 Variation Test Results Report," TRR-PLT073, Rev.0, Duratek, Inc., Columbia, MD, 10/27/03.

[29] “RPP-WTP Pilot Melter Sub-Envelope C1 Variation Test Results Report," TRR-PLT069, Rev.2, Duratek, Inc., Columbia, MD, 2/6/03.

[30] “RPP-WTP Pilot Melter Sub-Envelope C2 Variation Test Results Report,” TRR-PLT072, Rev.1, Duratek, Inc., Columbia, MD, 3/12/03.

[31] "LAW Glass Formulation Testing to Increase Waste Loading,” K.S. Matlack, H. Gan, I.S. Muller, and I.L. Pegg, VSL-05T5900-1, Rev. 0, Vitreous State Laboratory, The Catholic University of America, Washington, DC, 4/7/05.

[32] "LAW Envelope C Glass Formulation Testing to Increase Waste Loading," K.S. Matlack, W. Gong, I.S. Muller, and I.L. Pegg, VSL-05R5900-1, Rev. A, Vitreous State Laboratory, The Catholic University of America, Washington, DC, 8/29/05. 
[33] “Glass Formulation and Testing with TWRS LAW Simulants,” I.S. Muller and I.L. Pegg, Vitreous State Laboratory, The Catholic University of America, Washington, DC, $1 / 16 / 98$.

[34] “Glass Formulation And Testing With RPP-WTP LAW Simulants,” I.S. Muller, A.C. Buechele, and I.L. Pegg, Final Report, VSL-01R3560-2, Vitreous State Laboratory, The Catholic University of America, Washington, DC, 2/23/01.

[35] “Baseline LAW Glass Formulation Testing,” I.S. Muller and I.L. Pegg, VSL-03R3460-1, Rev.0, Vitreous State Laboratory, The Catholic University of America, Washington, DC, 8/8/03.

[36] “Glass Formulations to Support Melter Testing”, I.S. Muller and I.L. Pegg, VSL03R3460-2, Rev.0, Vitreous State Laboratory, The Catholic University of America, Washington, DC, 2/6/04.

[37] “Quality Assurance Project Plan for RPP-WTP Support Activities Conducted by VSL,” Vitreous State Laboratory, QAPP Rev. 8, Vitreous State Laboratory, The Catholic University of America, Washington, DC, 6/2/05.

[38] "Master List of Controlled VSL Manuals and Standard Operating Procedures in Use," QA-MLCP, Rev. 15, Vitreous State Laboratory, The Catholic University of America, Washington, DC, 6/6/05.

[39] "LAW Pilot Melter and DM-100 Sub-Envelope Changeover Testing," E.V. Morrey, WTP Test Specification, 24590-LAW-TSP-RT-02-012, Rev. 0.

[40] “Tank Farm Contractor Operation and Utilization Plan,” R.A. Kirkbride, et al., CH2M Hill Hanford Group Inc., Richland, WA, HNF-SD-SP-012, Rev. 3, 10/2/01.

[41] “Basis of Design,” BNFL report, DB-W375-EG00001, Rev. 0, November 23, 1998.

[42] "Physical and Rheological Properties of Waste Simulants and Melter Feeds for RPPWTP LAW Vitrification,” Final Report, I.S. Muller, H. Gan, and I.L. Pegg, VSL00R3520-1, Rev. 0, Vitreous State Laboratory, The Catholic University of America, Washington, DC, 1/16/01.

[43] “Characterization of Simulated WTP LAW Melter Feeds," Final Report, H. Zhao, I.S. Muller, and I.L. Pegg, VSL-04R4500-1, Rev. 0, Vitreous State Laboratory, The Catholic University of America, Washington, DC, 5/26/04.

[44] "Composition Effects on the Vapor Hydration of Waste Glasses," A.C. Buechele, F. Lofaj, I.S. Muller, C.T.F. Mooers, and I.L. Pegg, Ceramic Transactions, Vol. 155, p. 289, (2004). 
[45] "Phase 1 ILAW PCT and VHT Model Development,” I.S. Muller, H. Gan and I.L. Pegg, VSL-04R4480-2, Rev. 0, Vitreous State Laboratory, The Catholic University of America, Washington, DC, Washington, D.C., 2/8/05.

[46] Bechtel National, Inc. Design, Construction, and Commissioning of the Hanford Tank Waste Treatment and Immobilization Plant Contract Number: DE-AC27-01RV14136, 8/31/00.

[47] “LAW Container Centerline Cooling Data” RPP-WTP Memorandum, L. Petkus to C. Musick, CCN\# 074181, 10/16/03.

[48] "Enhanced K-3 Refractory Corrosion with LAW AZ-102 Glass Formulations,” I. S. Muller, H. Gan, A. C. Buechele, and I L. Pegg, VSL-02S4600-1, Rev.0, Vitreous State Laboratory, The Catholic University of America, Washington, DC, 6/25/02.

[49] "Integrated Off-Gas System Tests on the DM1200 Melter with RPP-WTP LAW SubEnvelope A1 Simulants,” K.S. Matlack, W. Gong, T. Bardakci, N. D’Angelo, and I.L. Pegg, VSL-02R8800-2, Rev. 0, Vitreous State Laboratory, The Catholic University of America, Washington, DC, 9/03/02.

[50] "Development of LAW and HLW Vitrification Physical Property Bounding Conditions and Simulant Verification Criteria," A. Poloski, H. Smith, G. Smith, and B. Calloway, WTP-RPT-075, Rev. 0, 2/03.

[51] "Integrated Off-Gas System Tests on the DM1200 Melter with RPP-WTP LAW SubEnvelope C1 Simulants,” K.S. Matlack, W. Gong, T. Bardakci, D’Angelo, and I.L. Pegg, VSL-02R8800-1, Rev. 0, Vitreous State Laboratory, The Catholic University of America, Washington, DC, 7/25/02.

[52] "Regulatory Off-Gas Emissions Testing on the DM1200 Melter System Using HLW and LAW Simulants,” K. S. Matlack, W. Gong, T. Bardakci, N. D'Angelo, M. Brandys, W. Kot, and I. L. Pegg, Final Report, VSL-05R5830-1, Rev. 0, Vitreous State Laboratory, The Catholic University of America, Washington, DC, 10/31/05.

[53] "DuraMelter 100 Tests to Support LAW Glass Formulation Correlation Development," K. S. Matlack and I. L. Pegg, Summary Report, VSL-05S5480-1, Rev. 0, 11/10/05.

[54] "Round Robin Testing of a Reference Glass for Low-Activity Waste Forms," W.L. Ebert and S.F. Wolf, Department of Energy report ANL-99/22, Argonne National Laboratory, Argonne, IL, 1999.

[55] "Comparison of Off-Gas Emissions from Tests with LAW Simulants on the DM100, DM1200, and DM3300 Melters,” R.A. Callow, K.S. Matlack, and I.L. Pegg, Summary Report, VSL-04S4850-1, Rev. 0, Vitreous State Laboratory, The Catholic University of America, Washington, DC, 4/19/04. 
The Catholic University of America

Vitreous State Laboratory
LAW Envelope A and B Glass Formulations Testing

to Increase Waste Loading Final Report, VSL-06R6900-1, Rev. 0

[56] "Integrated Off-Gas System Tests on the DM1200 Melter with RPP-WTP LAW SubEnvelope B1 Simulants,” K.S. Matlack, W. Gong, T. Bardakci, N. D’Angelo, and I.L. Pegg, VSL-03R3851-1, Rev. 0, Vitreous State Laboratory, The Catholic University of America, Washington, DC, 10/17/03.

[57] “DuraMelter 100 Tests to Support LAW Glass Formulation Correlation Development," K. S. Matlack, I. S. Muller, W. Gong, and I. L. Pegg, VSL-06R6480-1, Rev. 0, Vitreous State Laboratory, The Catholic University of America, Washington, DC, 3/21/06.

[58] "Proposed Approach for Development of LAW Glass Formulation Correlation," I.S. Muller, G. Diener, I. Joseph, and I.L. Pegg, VSL-04L4460-1, Rev. 2, Vitreous State Laboratory, The Catholic University of America, Washington, DC, 10/29/04.

[59] "Pilot Melter High Temperature Operation Assessment Test Results Report,” TRR-PLT081, Rev.0, Duratek, Inc., Columbia, MD, 2/12/04.

[60] "LAW Pilot Melter Decommissioning Project - Second Generation LAW Melter Conceptual Design Report,” REP-LDD-001, Rev.0, Duratek, Inc., Columbia, MD, 12/22/03. 
Table 2.1. LAW Sub-Envelope A1 (AN-105) Waste Simulant Recipe at 8 Molar Sodium.

\begin{tabular}{|c|c|c|c|c|c|c|c|c|c|}
\hline \multirow{2}{*}{\begin{tabular}{|c}
$\begin{array}{c}\text { Envelope } \\
\text { Constituents }\end{array}$ \\
- \\
\end{tabular}} & \multicolumn{2}{|c|}{$\begin{array}{c}\text { Simulant AN-105 } \\
\text { including pretreatment }\end{array}$} & \multirow{2}{*}{$\begin{array}{c}\text { Glass } \\
\text { Oxides }\end{array}$} & \multirow{2}{*}{$\begin{array}{c}\text { AN-105 } \\
\text { (wt\%) }\end{array}$} & $\begin{array}{l}\text { Source in } \\
\text { Simulant }\end{array}$ & $\begin{array}{l}\text { Order for } \\
\text { Addition }\end{array}$ & $\begin{array}{c}\text { Formula } \\
\text { Weight }\end{array}$ & Assay* & $\begin{array}{c}\text { Target } \\
\text { Weight (g) }\end{array}$ \\
\hline & $\mathrm{mg} / \mathrm{L}$ & $\mathrm{M}$ & & & \multicolumn{5}{|c|}{ In $274.40 \mathrm{ml}$ water add following compounds in the order listed below } \\
\hline \multirow{2}{*}{$\mathrm{Al}$} & \multirow{2}{*}{30554} & \multirow{2}{*}{1.132} & \multirow{2}{*}{$\mathrm{Al}_{2} \mathrm{O}_{3}$} & \multirow{2}{*}{17.613} & $\mathrm{Al}\left(\mathrm{NO}_{3}\right) 3.9 \mathrm{H}_{2} \mathrm{O}, 60 \%$ sol. & 1 & 375.14 & 0.61 & 422.01 \\
\hline & & & & & $\mathrm{Al}(\mathrm{OH})_{3}$ & 8 & 78.00 & 1.00 & 35.56 \\
\hline $\mathrm{B}$ & 79 & 0.007 & $\mathrm{~B}_{2} \mathrm{O}_{3}$ & 0.077 & $\mathrm{H}_{3} \mathrm{BO}_{3}$ & 3 & 61.83 & 0.99 & 0.45 \\
\hline $\mathrm{Cr}$ & 149 & 0.003 & $\mathrm{Cr}_{2} \mathrm{O}_{3}$ & 0.066 & $\mathrm{Na}_{2} \mathrm{CrO}_{4} * 4 \mathrm{H}_{2} \mathrm{O}$ & 7 & 234.04 & 0.99 & 0.68 \\
\hline K & 4608 & 0.118 & $\mathrm{~K}_{2} \mathrm{O}$ & 1.694 & $\mathrm{KOH}$ & 6 & 56.10 & 0.91 & 7.28 \\
\hline $\mathrm{Na}$ & 183920 & 8.000 & $\mathrm{Na}_{2} \mathrm{O}$ & 75.638 & $\mathrm{NaOH}, 50 \%$ sol. $\mathrm{d}=1.53$ & 5 & 40.00 & 0.50 & 449.56 \\
\hline $\mathrm{Si}$ & 157 & 0.006 & $\mathrm{SiO}_{2}$ & 0.102 & $\mathrm{SiO}_{2}$ & 4 & 60.09 & 0.99 & 0.34 \\
\hline $\mathrm{Cl}$ & 6996 & 0.197 & $\mathrm{Cl}$ & 2.134 & $\mathrm{NaCl}$ & 9 & 58.45 & 0.99 & 11.65 \\
\hline$F$ & 35 & 0.002 & $\mathrm{~F}$ & 0.011 & $\mathrm{NaF}$ & 10 & 42.00 & 0.99 & 0.08 \\
\hline $\mathrm{SO}_{4}$ & 10488 & 0.109 & $\mathrm{SO}_{3}$ & 2.667 & $\mathrm{Na}_{2} \mathrm{SO}_{4}$ & 11 & 142.06 & 0.99 & 15.67 \\
\hline $\mathrm{NO}_{2}$ & 85428 & 1.857 & - & - & $\mathrm{NaNO}_{2}$ & 15 & 69.00 & 0.97 & 128.79 \\
\hline $\mathrm{NO}_{3}$ & 126988 & 2.048 & - & - & $\mathrm{NaNO}_{3}$ & - & 84.99 & 0.99 & 0.00 \\
\hline TOC & 2093 & 0.174 & - & - & - & - & - & - & - \\
\hline Acetate & 2251 & 0.038 & - & - & Sodium Acetate (C2) & 12 & 136.08 & 0.99 & 5.24 \\
\hline Formate & 2135 & 0.047 & - & - & Sodium Formate (C1) & 13 & 68.01 & 0.99 & 3.26 \\
\hline Glycolate & 1936 & 0.025 & - & - & Glycolic Acid (C2) & 14 & 76.05 & 0.71 & 2.73 \\
\hline- & - & - & SUM & 100.0 & & simulant $\mathrm{w}$ & & & 1357.35 \\
\hline
\end{tabular}

- Empty data field.

* - Assay refers to the purity of the raw material as specified by the vendor. 
Table 2.2. Target and Analyzed Compositions (wt\%) of Seventeen Envelope A Crucible Glasses with $23 \mathrm{wt} \% \mathrm{Na}_{2} \mathrm{O}$ or 30.4 wt\% Waste Loading.

\begin{tabular}{|c|c|c|c|c|c|c|c|c|c|c|c|c|}
\hline \multirow{2}{*}{$\begin{array}{l}\text { GLASS } \\
\text { Oxides }\end{array}$} & \multicolumn{2}{|c|}{ LAWA171 } & \multicolumn{2}{|c|}{ LAWA172 } & \multicolumn{2}{|c|}{ LAWA173 } & \multicolumn{2}{|c|}{ LAWA174 } & \multicolumn{2}{|c|}{ LAWA175 } & \multicolumn{2}{|c|}{ LAWA176 } \\
\hline & Target & Analyzed* & Target & Analyzed* & Target & Analyzed* & Target & Analyzed* & Target & Analyzed $^{*}$ & Target & Analyzed \\
\hline $\mathrm{Al}_{2} \mathrm{O}_{3}$ & 10.16 & 9.97 & 10.65 & 10.44 & 10.65 & 10.34 & 10.65 & 10.34 & 12.15 & 11.89 & 13.65 & 13.66 \\
\hline $\mathrm{B}_{2} \mathrm{O}_{3}$ & 13.68 & $13.98^{*}$ & 12.79 & $13.16^{*}$ & 11.29 & $11.62^{*}$ & 9.79 & $10.28^{*}$ & 11.29 & $11.78^{*}$ & 9.79 & $10.11^{*}$ \\
\hline $\mathrm{CaO}$ & 5.65 & 5.22 & 7.99 & 7.78 & 7.99 & 7.57 & 7.99 & 7.73 & 7.99 & 7.52 & 7.99 & 7.74 \\
\hline $\mathrm{Cr}_{2} \mathrm{O}_{3}$ & 0.02 & 0.03 & 0.02 & 0.03 & 0.02 & 0.03 & 0.02 & 0.01 & 0.02 & 0.02 & 0.02 & 0.02 \\
\hline $\mathrm{Fe}_{2} \mathrm{O}_{3}$ & 1.00 & 0.99 & 0.91 & 0.95 & 0.91 & 0.94 & 0.91 & 0.95 & 0.91 & 0.92 & 0.91 & 0.95 \\
\hline $\mathrm{K}_{2} \mathrm{O}$ & 0.51 & 0.56 & 0.51 & 0.54 & 0.51 & 0.53 & 0.51 & 0.56 & 0.51 & 0.56 & 0.51 & 0.54 \\
\hline $\mathrm{MgO}$ & 1.00 & 1.04 & 0.91 & 0.93 & 0.91 & 1.02 & 0.91 & 0.78 & 0.91 & 0.95 & 0.91 & 0.96 \\
\hline $\mathrm{Na}_{2} \mathrm{O}$ & 23.00 & 23.99 & 23.00 & 23.12 & 23.00 & 23.79 & 23.00 & 23.05 & 23.00 & 23.55 & 23.00 & 23.28 \\
\hline $\mathrm{SiO}_{2}$ & 36.58 & 38.56 & 34.86 & 36.95 & 34.86 & 36.60 & 34.86 & 36.78 & 34.86 & 36.90 & 34.86 & 36.93 \\
\hline $\mathrm{SnO}_{2}$ & 0.00 & 0.00 & 0.00 & 0.00 & 0.00 & 0.00 & 0.00 & 0.00 & 0.00 & 0.00 & 0.00 & 0.00 \\
\hline $\mathrm{V}_{2} \mathrm{O}_{5}$ & 1.00 & 1.13 & 0.98 & 1.14 & 0.98 & 1.11 & 0.98 & 1.14 & 0.98 & 1.12 & 0.98 & 1.14 \\
\hline $\mathrm{ZnO}$ & 3.00 & 2.71 & 3.00 & 2.91 & 3.00 & 2.84 & 3.00 & 2.89 & 3.00 & 2.82 & 3.00 & 2.90 \\
\hline $\mathrm{ZrO}_{2}$ & 3.00 & 2.96 & 3.00 & 3.24 & 4.50 & 4.76 & 6.00 & 6.54 & 3.00 & 3.19 & 3.00 & 3.11 \\
\hline $\mathrm{Cl}$ & 0.65 & 0.54 & 0.65 & 0.38 & 0.65 & 0.35 & 0.65 & 0.50 & 0.65 & 0.54 & 0.65 & 0.38 \\
\hline $\mathrm{F}$ & 0.00 & NA & 0.00 & NA & 0.00 & NA & 0.00 & NA & 0.00 & NA & 0.00 & NA \\
\hline $\mathrm{P}_{2} \mathrm{O}_{5}$ & 0.00 & 0.00 & 0.00 & 0.00 & 0.00 & 0.00 & 0.00 & 0.00 & 0.00 & 0.00 & 0.00 & 0.01 \\
\hline $\mathrm{SO}_{3}$ & 0.75 & 0.67 & 0.75 & 0.68 & 0.75 & 0.66 & 0.75 & 0.69 & 0.75 & 0.71 & 0.75 & 0.67 \\
\hline SUM & 100.0 & 102.4 & 100.0 & 102.3 & 100.0 & 102.2 & 100.0 & 102.2 & 100.0 & 102.5 & 100.0 & 102.4 \\
\hline
\end{tabular}

* - Analyzed by X-ray fluorescence except for boron which was measured by DCP

NA - Not analyzed 
Table 2.2. Target and Analyzed Compositions (wt\%) of Seventeen Envelope A Crucible Glasses with 23 wt\% $\mathrm{Na}_{2} \mathrm{O}$ or 30.4 wt\% Waste Loading (continued) .

\begin{tabular}{|c|c|c|c|c|c|c|c|c|c|c|c|c|}
\hline \multirow{2}{*}{$\begin{array}{l}\text { GLASS } \\
\text { Oxides }\end{array}$} & \multicolumn{2}{|c|}{ LAWA183 } & \multicolumn{2}{|c|}{ LAWA184 } & \multicolumn{2}{|c|}{ LAWA185 } & \multicolumn{2}{|c|}{ LAWA186 } & \multicolumn{2}{|c|}{ LAWA187 } & \multicolumn{2}{|c|}{ LAWA188 } \\
\hline & Target & Analyzed ${ }^{*}$ & Target & Analyzed* & Target & Analyzed ${ }^{*}$ & Target & Analyzed ${ }^{*}$ & Target & Analyzed ${ }^{*}$ & Target & Analyzed ${ }^{*}$ \\
\hline $\mathrm{Al}_{2} \mathrm{O}_{3}$ & 10.65 & 10.93 & 10.65 & 10.99 & 12.15 & 12.49 & 11.64 & 11.97 & 10.65 & 10.09 & 10.65 & 10.06 \\
\hline $\mathrm{B}_{2} \mathrm{O}_{3}$ & 9.79 & $10.64^{*}$ & 9.42 & $10.26^{*}$ & 9.79 & $10.73^{*}$ & 9.30 & $10.21^{*}$ & 12.79 & $13.79^{*}$ & 12.79 & $13.81^{*}$ \\
\hline $\mathrm{CaO}$ & 7.99 & 7.70 & 7.66 & 7.41 & 7.99 & 7.73 & 7.99 & 7.60 & 6.48 & 6.55 & 5.48 & 5.41 \\
\hline $\mathrm{Cr}_{2} \mathrm{O}_{3}$ & 0.02 & 0.03 & 0.02 & 0.02 & 0.02 & 0.02 & 0.02 & 0.02 & 0.52 & 0.60 & 0.52 & 0.56 \\
\hline $\mathrm{Fe}_{2} \mathrm{O}_{3}$ & 0.91 & 0.96 & 0.91 & 0.94 & 0.91 & 0.94 & 0.91 & 0.92 & 0.91 & 1.01 & 0.91 & 1.01 \\
\hline $\mathrm{K}_{2} \mathrm{O}$ & 0.51 & 0.58 & 0.51 & 0.59 & 0.51 & 0.56 & 0.51 & 0.57 & 0.51 & 0.56 & 0.51 & 0.56 \\
\hline $\mathrm{MgO}$ & 0.91 & 0.83 & 0.91 & 0.79 & 0.91 & 0.84 & 0.91 & 0.85 & 0.91 & 0.79 & 0.91 & 0.79 \\
\hline $\mathrm{Na}_{2} \mathrm{O}$ & 23.00 & 21.66 & 23.00 & 20.82 & 23.00 & 21.44 & 23.00 & 21.52 & 23.00 & 23.18 & 23.00 & 23.36 \\
\hline $\mathrm{SiO}_{2}$ & 34.34 & 37.37 & 36.58 & 40.16 & 36.88 & 40.26 & 36.88 & 40.24 & 34.86 & 34.59 & 34.86 & 34.69 \\
\hline $\mathrm{SnO}_{2}$ & 0.00 & 0.00 & 0.00 & 0.00 & 0.00 & 0.00 & 0.00 & 0.00 & 1.00 & 1.19 & 2.01 & 2.29 \\
\hline $\mathrm{V}_{2} \mathrm{O}_{5}$ & 1.50 & 1.73 & 1.50 & 1.77 & 1.50 & 1.75 & 1.50 & 1.70 & 0.98 & 1.19 & 0.98 & 1.18 \\
\hline $\mathrm{ZnO}$ & 3.00 & 2.83 & 1.45 & 1.38 & 1.95 & 1.84 & 1.45 & 1.33 & 3.00 & 2.93 & 3.00 & 2.87 \\
\hline $\mathrm{ZrO}_{2}$ & 6.00 & 6.26 & 6.00 & 5.96 & 3.00 & 2.96 & 4.50 & 4.45 & 3.00 & 3.25 & 3.00 & 3.15 \\
\hline $\mathrm{Cl}$ & 0.65 & 0.49 & 0.65 & 0.57 & 0.65 & 0.50 & 0.65 & 0.53 & 0.65 & 0.53 & 0.65 & 0.52 \\
\hline $\mathrm{F}$ & 0.00 & NA & 0.00 & NA & 0.00 & NA & 0.00 & NA & 0.00 & NA & 0.00 & NA \\
\hline $\mathrm{P}_{2} \mathrm{O}_{5}$ & 0.00 & 0.00 & 0.00 & 0.00 & 0.00 & 0.00 & 0.00 & 0.00 & 0.00 & 0.01 & 0.00 & 0.00 \\
\hline $\mathrm{SO}_{3}$ & 0.75 & 0.66 & 0.75 & 0.83 & 0.75 & 0.70 & 0.75 & 0.76 & 0.75 & 0.62 & 0.75 & 0.61 \\
\hline SUM & 100.0 & 102.7 & 100.0 & 102.5 & 100.0 & 102.8 & 100.0 & 102.7 & 100.0 & 100.9 & 100.0 & 100.9 \\
\hline
\end{tabular}


Table 2.2. Target and Analyzed Compositions (wt\%) of Seventeen Envelope A Crucible Glasses with 23 wt \% $\mathrm{Na}_{2} \mathrm{O}$ or 30.4 wt\% Waste Loading (continued).

\begin{tabular}{|c|c|c|c|c|c|c|c|c|c|c|}
\hline \multirow{2}{*}{$\begin{array}{l}\text { GLASS } \\
\text { Oxides }\end{array}$} & \multicolumn{2}{|c|}{ LAWA189 } & \multicolumn{2}{|c|}{ LAWA190 } & \multicolumn{2}{|c|}{ LAWA191 } & \multicolumn{2}{|c|}{ LAWA192 } & \multicolumn{2}{|c|}{ LAWA193 } \\
\hline & Target & Analyzed ${ }^{*}$ & Target & Analyzed ${ }^{*}$ & Target & Analyzed* & Target & Analyzed* & Target & Analyzed* \\
\hline $\mathrm{Al}_{2} \mathrm{O}_{3}$ & 10.65 & 10.17 & 12.15 & 11.45 & 12.15 & 11.46 & 12.15 & 11.51 & 12.15 & 11.51 \\
\hline $\mathrm{B}_{2} \mathrm{O}_{3}$ & 11.29 & $11.51^{*}$ & 11.29 & $11.66^{*}$ & 11.29 & $11.78^{*}$ & 11.29 & $11.67^{*}$ & 11.29 & $11.65^{*}$ \\
\hline $\mathrm{CaO}$ & 7.49 & 7.50 & 5.98 & 6.17 & 7.49 & 7.67 & 5.98 & 6.11 & 5.48 & 5.65 \\
\hline $\mathrm{Cr}_{2} \mathrm{O}_{3}$ & 0.52 & 0.58 & 0.52 & 0.58 & 0.52 & 0.60 & 0.02 & 0.03 & 0.52 & 0.61 \\
\hline $\mathrm{Fe}_{2} \mathrm{O}_{3}$ & 0.91 & 0.99 & 0.91 & 1.03 & 0.91 & 1.03 & 0.91 & 1.02 & 0.91 & 1.02 \\
\hline $\mathrm{K}_{2} \mathrm{O}$ & 0.51 & 0.55 & 0.51 & 0.56 & 0.51 & 0.57 & 0.51 & 0.58 & 0.51 & 0.57 \\
\hline MgO & 0.91 & 0.86 & 0.91 & 0.76 & 0.91 & 0.69 & 0.91 & 0.84 & 0.91 & 0.76 \\
\hline $\mathrm{Na}_{2} \mathrm{O}$ & 23.00 & 23.13 & 23.00 & 22.81 & 23.00 & 23.13 & 23.00 & 23.24 & 23.00 & 22.95 \\
\hline $\mathrm{SiO}_{2}$ & 34.86 & 35.23 & 34.86 & 34.85 & 34.86 & 34.83 & 35.86 & 35.88 & 35.86 & 35.88 \\
\hline $\mathrm{SnO}_{2}$ & 0.00 & 0.01 & 0.00 & 0.00 & 0.00 & 0.00 & 0.00 & 0.00 & 0.00 & 0.00 \\
\hline $\mathrm{TiO}_{2}$ & 0.00 & 0.01 & 0.00 & 0.02 & 0.00 & 0.02 & 0.00 & 0.01 & 0.00 & 0.02 \\
\hline $\mathrm{V}_{2} \mathrm{O}_{5}$ & 0.98 & 1.16 & 0.98 & 1.19 & 0.98 & 1.19 & 0.98 & 1.18 & 0.98 & 1.19 \\
\hline $\mathrm{ZnO}$ & 3.00 & 2.86 & 3.00 & 2.98 & 3.00 & 3.00 & 3.00 & 2.96 & 3.00 & 2.96 \\
\hline $\mathrm{ZrO}_{2}$ & 4.50 & 4.44 & 4.50 & 5.04 & 3.00 & 3.29 & 4.00 & 4.04 & 4.00 & 4.30 \\
\hline $\mathrm{Cl}$ & 0.65 & 0.50 & 0.65 & 0.54 & 0.65 & 0.54 & 0.65 & 0.51 & 0.65 & 0.54 \\
\hline $\mathrm{F}$ & 0.00 & NA & 0.00 & NA & 0.00 & NA & 0.00 & NA & 0.00 & NA \\
\hline $\mathrm{P}_{2} \mathrm{O}_{5}$ & 0.00 & 0.01 & 0.00 & 0.01 & 0.00 & 0.01 & 0.00 & 0.00 & 0.00 & 0.01 \\
\hline $\mathrm{SO}_{3}$ & 0.75 & 0.61 & 0.75 & 0.59 & 0.75 & 0.61 & 0.75 & 0.68 & 0.75 & 0.62 \\
\hline SUM & 100.0 & 100.1 & 100.0 & 100.2 & 100.0 & 100.4 & 100.0 & 100.3 & 100.0 & 100.2 \\
\hline
\end{tabular}


Table 2.3. Target and Analyzed Compositions (wt\%) of Ten Envelope A Crucible Glasses with 25 wt \% $\mathrm{Na}_{2} \mathrm{O}$ or 32.9 wt\% Waste Loading.

\begin{tabular}{|c|c|c|c|c|c|c|c|c|c|c|}
\hline \multirow{2}{*}{$\begin{array}{l}\text { GLASS } \\
\text { Oxides }\end{array}$} & \multicolumn{2}{|c|}{ LAWA177 } & \multicolumn{2}{|c|}{ LAWA178 } & \multicolumn{2}{|c|}{ LAWA179 } & \multicolumn{2}{|c|}{ LAWA180 } & \multicolumn{2}{|c|}{ LAWA181 } \\
\hline & Target & Analyzed ${ }^{*}$ & Target & Analyzed ${ }^{*}$ & Target & Analyzed* & Target & Analyzed ${ }^{*}$ & Target & Analyzed ${ }^{*}$ \\
\hline $\mathrm{Al}_{2} \mathrm{O}_{3}$ & 10.16 & 9.81 & 10.85 & 10.63 & 10.85 & 10.56 & 10.85 & 10.61 & 12.36 & 12.03 \\
\hline $\mathrm{B}_{2} \mathrm{O}_{3}$ & 13.66 & $14.28^{*}$ & 10.76 & $11.08^{*}$ & 9.26 & $9.71^{*}$ & 7.76 & $7.99^{*}$ & 9.26 & $9.63^{*}$ \\
\hline $\mathrm{CaO}$ & 3.65 & 3.59 & 7.98 & 7.74 & 7.98 & 7.69 & 7.98 & 8.03 & 7.98 & 7.89 \\
\hline $\mathrm{Cr}_{2} \mathrm{O}_{3}$ & 0.02 & 0.03 & 0.02 & 0.03 & 0.02 & 0.03 & 0.02 & 0.02 & 0.02 & 0.03 \\
\hline $\mathrm{Fe}_{2} \mathrm{O}_{3}$ & 1.00 & 1.06 & 0.91 & 0.97 & 0.91 & 0.94 & 0.91 & 0.96 & 0.91 & 0.99 \\
\hline $\mathrm{K}_{2} \mathrm{O}$ & 0.56 & 0.60 & 0.56 & 0.61 & 0.56 & 0.59 & 0.56 & 0.58 & 0.56 & 0.63 \\
\hline $\mathrm{MgO}$ & 1.00 & 1.05 & 0.91 & 0.95 & 0.91 & 0.95 & 0.91 & 0.92 & 0.91 & 0.98 \\
\hline $\mathrm{Na}_{2} \mathrm{O}$ & 25.00 & 25.75 & 25.00 & 24.82 & 25.00 & 25.42 & 25.00 & 24.45 & 25.00 & 24.83 \\
\hline $\mathrm{SiO}_{2}$ & 36.58 & 37.83 & 35.32 & 37.44 & 35.32 & 36.91 & 35.32 & 37.42 & 35.32 & 37.29 \\
\hline $\mathrm{SnO}_{2}$ & 0.00 & 0.00 & 0.00 & 0.00 & 0.00 & 0.00 & 0.00 & 0.00 & 0.00 & 0.00 \\
\hline $\mathrm{V}_{2} \mathrm{O}_{5}$ & 1.00 & 1.20 & 0.94 & 1.12 & 0.94 & 1.11 & 0.94 & 1.12 & 0.94 & 1.13 \\
\hline $\mathrm{ZnO}$ & 2.96 & 2.92 & 2.35 & 2.30 & 2.35 & 2.26 & 2.35 & 2.32 & 2.35 & 2.36 \\
\hline $\mathrm{ZrO}_{2}$ & 2.96 & 3.13 & 2.95 & 3.21 & 4.45 & 4.80 & 5.95 & 6.36 & 2.95 & 3.17 \\
\hline $\mathrm{Cl}$ & 0.71 & 0.56 & 0.71 & 0.53 & 0.71 & 0.55 & 0.71 & 0.43 & 0.71 & 0.58 \\
\hline $\mathrm{F}$ & 0.00 & NA & 0.00 & NA & 0.00 & NA & 0.00 & NA & 0.00 & NA \\
\hline $\mathrm{P}_{2} \mathrm{O}_{5}$ & 0.00 & 0.00 & 0.00 & 0.01 & 0.00 & 0.00 & 0.00 & 0.01 & 0.00 & 0.00 \\
\hline $\mathrm{SO}_{3}$ & 0.75 & 0.70 & 0.75 & 0.71 & 0.75 & 0.69 & 0.75 & 0.70 & 0.75 & 0.71 \\
\hline SUM & 100.0 & 102.5 & 100.0 & 102.2 & 100.0 & 102.2 & 100.0 & 101.9 & 100.0 & 102.3 \\
\hline
\end{tabular}

* Analyzed by X-ray fluorescence except for boron which was measured by DCP

NA - Not analyzed 
Table 2.3. Target and Analyzed Compositions (wt\%) of Ten Envelope A Crucible Glasses with 25 wt \% $\mathrm{Na}_{2} \mathrm{O}$ or 32.9 wt\% Waste Loading (continued).

\begin{tabular}{|c|c|c|c|c|c|c|c|c|c|c|}
\hline \multirow{2}{*}{$\begin{array}{l}\text { GLASS } \\
\text { Oxides }\end{array}$} & \multicolumn{2}{|c|}{ LAWA182 } & \multicolumn{2}{|c|}{ LAWA194 } & \multicolumn{2}{|c|}{ LAWA195 } & \multicolumn{2}{|c|}{ LAWA196 } & \multicolumn{2}{|c|}{ LAWA197 } \\
\hline & Target & Analyzed ${ }^{*}$ & Target & Analyzed ${ }^{*}$ & Target & Analyzed ${ }^{*}$ & Target & Analyzed ${ }^{*}$ & Target & Analyzed ${ }^{*}$ \\
\hline $\mathrm{Al}_{2} \mathrm{O}_{3}$ & 13.85 & 13.55 & 10.85 & 10.14 & 10.85 & 10.11 & 11.85 & 11.16 & 11.85 & 11.18 \\
\hline $\mathrm{B}_{2} \mathrm{O}_{3}$ & 7.76 & $8.21^{*}$ & 7.76 & $8.18^{*}$ & 7.76 & $8.05^{*}$ & 7.76 & $8.02^{*}$ & 7.76 & $8.25^{*}$ \\
\hline $\mathrm{CaO}$ & 7.98 & 7.79 & 6.98 & 7.01 & 6.48 & 6.55 & 5.98 & 5.97 & 5.48 & 5.55 \\
\hline $\mathrm{Cr}_{2} \mathrm{O}_{3}$ & 0.02 & 0.03 & 0.02 & 0.03 & 0.53 & 0.60 & 0.02 & 0.03 & 0.53 & 0.58 \\
\hline $\mathrm{Fe}_{2} \mathrm{O}_{3}$ & 0.91 & 0.97 & 0.91 & 1.05 & 0.91 & 1.04 & 0.91 & 1.00 & 0.91 & 0.99 \\
\hline $\mathrm{K}_{2} \mathrm{O}$ & 0.56 & 0.59 & 0.56 & 0.59 & 0.56 & 0.60 & 0.56 & 0.59 & 0.56 & 0.61 \\
\hline $\mathrm{MgO}$ & 0.91 & 0.97 & 0.91 & 0.86 & 0.91 & 0.84 & 0.91 & 0.85 & 0.91 & 0.59 \\
\hline $\mathrm{Na}_{2} \mathrm{O}$ & 25.00 & 25.27 & 25.00 & 25.23 & 25.00 & 25.46 & 25.00 & 25.12 & 25.00 & 24.96 \\
\hline $\mathrm{SiO}_{2}$ & 35.32 & 37.21 & 35.32 & 34.71 & 35.32 & 34.38 & 36.32 & 36.37 & 36.32 & 36.20 \\
\hline $\mathrm{SnO}_{2}$ & 0.00 & 0.01 & 1.00 & 1.20 & 1.00 & 1.20 & 0.00 & 0.01 & 0.00 & 0.01 \\
\hline $\mathrm{V}_{2} \mathrm{O}_{5}$ & 0.94 & 1.14 & 0.94 & 1.11 & 0.94 & 1.13 & 0.94 & 1.12 & 0.94 & 1.13 \\
\hline $\mathrm{ZnO}$ & 2.35 & 2.34 & 2.35 & 2.33 & 2.35 & 2.36 & 2.35 & 2.25 & 2.35 & 2.31 \\
\hline $\mathrm{ZrO}_{2}$ & 2.95 & 3.19 & 5.95 & 6.59 & 5.95 & 6.57 & 5.95 & 6.36 & 5.95 & 6.51 \\
\hline $\mathrm{Cl}$ & 0.71 & 0.45 & 0.71 & 0.57 & 0.71 & 0.59 & 0.71 & 0.62 & 0.71 & 0.59 \\
\hline $\mathrm{F}$ & 0.00 & NA & 0.00 & NA & 0.00 & NA & 0.00 & NA & 0.00 & NA \\
\hline $\mathrm{P}_{2} \mathrm{O}_{5}$ & 0.00 & 0.01 & 0.00 & 0.01 & 0.00 & 0.01 & 0.00 & 0.00 & 0.00 & 0.01 \\
\hline $\mathrm{SO}_{3}$ & 0.75 & 0.71 & 0.75 & 0.58 & 0.75 & 0.58 & 0.75 & 0.62 & 0.75 & 0.59 \\
\hline SUM & 100.0 & 102.4 & 100.00 & 100.2 & 100.0 & 100.1 & 100.0 & 100.1 & 100.0 & 100.1 \\
\hline
\end{tabular}

* Analyzed by X-ray fluorescence except for boron which was measured by DCP

NA - Not analyzed 
Table 2.4. Descriptions of Seventeen As-Melted and Heat Treated Envelope A Crucible Glasses with 23 wt \% $\mathrm{Na}_{2} \mathrm{O}$ or 30.4 wt\% Waste Loading.

\begin{tabular}{|c|c|c|c|}
\hline Glass ID & Glass as melted & $\begin{array}{l}\text { Glass remelted at } 1200^{\circ} \mathrm{C} \text { for } 1 \text { hour, heat treated } \\
\text { for } 20 \text { hours at } 950^{\circ} \mathrm{C} \text {, and quenched. }\end{array}$ & $\begin{array}{l}\text { Glass remelted at } 1200^{\circ} \mathrm{C} \text { for } 1 \text { hour, heat treated for } 20 \\
\text { hours at } 850^{\circ} \mathrm{C} \text {, and quenched. }\end{array}$ \\
\hline LAWA171 & clear green glass & Not tested & clear green glass \\
\hline LAWA172 & clear green glass & Not tested & clear green glass \\
\hline LAWA173 & clear green glass & clear green glass & mostly clear green glass - small amount of dendritic phase \\
\hline LAWA174 & clear green glass & clear green glass & 1-2 mm crystal layer at bottom of sample \\
\hline LAWA175 & clear green glass & mostly green clear glass & 3-4 mm crystal layer at bottom of sample \\
\hline LAWA176 & clear green glass & $\begin{array}{c}0.8 \text { vol\% on average of Na-Al-silicate sodalite } \\
\text { high in } \mathrm{SO}_{3} \text { and } \mathrm{Cl} \\
\end{array}$ & $9 \mathrm{vol} \%$ on average of $\mathrm{Na}-\mathrm{Al}$-silicate sodalite \\
\hline LAWA183 & clear green glass & $\begin{array}{c}\sim 0.4 \text { vol\% of large sodalite crystals periodically } \\
\text { observed along crucible contact }\end{array}$ & clear green glass with $1.5 \mathrm{~mm}$ dendritic phase at bottom \\
\hline LAWA184 & clear green glass & clear green glass & clear green glass with $1-1.5 \mathrm{~mm}$ dendritic phase at bottom \\
\hline LAWA185 & clear green glass & $\begin{array}{l}\text { clear green glass with }<1 \text { vol\% secondary phases } \\
\text { at bottom }\end{array}$ & clear green glass with $1-2 \mathrm{~mm}$ dendritic phase at bottom \\
\hline LAWA186 & clear green glass & clear green glass & clear green glass with 1mm dendritic phase at bottom \\
\hline LAWA187 & clear green glass & $<1$ vol\% crystals of $1-10$ micron size & $\begin{array}{l}\text { clear green glass with minute dendritic phase forming at } \\
\text { bottom crucible contact }\end{array}$ \\
\hline LAWA188 & clear green glass & $\begin{array}{l}\text { moderate optical clarity at bottom part of sample; } \\
\text { however, SEM examination showed a clear glass }\end{array}$ & moderate optical clarity \\
\hline LAWA189 & 0.5-2 vol\% particles & $\sim 0.1$ vol.\% of a Cr-Zn-Mg-Al spinel & moderate optical clarity ; dendritic phase at bottom \\
\hline LAWA190 & 0.5-2 vol\% particles & $\begin{array}{c}\text { moderate optical clarity; } 0.5-2 \text { vol\% reddish } \\
\text { particulates }\end{array}$ & opaque with green and red regions \\
\hline LAWA191 & 0.5-2 vol\% particles & $\begin{array}{l}1.5 \text { vol.\% sodalite crystals along crucible contact } \\
\text { and some Cr-Zn-Al-Mg spinel }\end{array}$ & opaque with green and red regions \\
\hline LAWA192 & $\begin{array}{l}\text { entrapped bubbles, but no } \\
\text { crystals by SEM }\end{array}$ & clear green glass & clear green glass with $1 \mathrm{~mm}$ dendritic phase at bottom \\
\hline LAWA193 & 0.5-2 vol\% particles & $0.5-2$ vol\% reddish particulates & opaque with green and red regions \\
\hline
\end{tabular}


Table 2.5. Descriptions of Ten As-Melted and Heat Treated Envelope A Crucible Glasses with 25 wt \% $\mathrm{Na}_{2} \mathrm{O}$ or 32.9 wt\% waste loading.

\begin{tabular}{|c|c|c|c|}
\hline Glass ID & Glass as melted & $\begin{array}{l}\text { Glass remelted at } 1200^{\circ} \mathrm{C} \text { for } 1 \text { hour, heat } \\
\text { treated for } 20 \text { hours at } 950^{\circ} \mathrm{C} \text {, and quenched. }\end{array}$ & $\begin{array}{l}\text { Glass remelted at } 1200^{\circ} \mathrm{C} \text { for } 1 \text { hour, heat } \\
\text { treated for } 20 \text { hours at } 850^{\circ} \mathrm{C} \text {, and quenched. }\end{array}$ \\
\hline LAWA177 & clear green glass & Not tested & clear green glass \\
\hline LAWA178 & clear green glass & Not tested & clear green glass \\
\hline LAWA179 & clear green glass & green clear glass & 1-2 mm crystal layer at bottom \\
\hline LAWA180 & clear green glass & $<1 \%$ vol\% crystals & 3-5 mm crystal layer at bottom \\
\hline LAWA181 & clear green glass & few crystals & 3-4 mm crystal layer at bottom \\
\hline LAWA182 & clear green glass & few crystals & $\begin{array}{l}\text { fully crystallized throughout the bulk of the } \\
\text { sample }\end{array}$ \\
\hline LAWA194 & clear green glass & clear green glass & $\begin{array}{l}\text { clear green glass with dendritic phase from } \\
\text { bottom to bulk }\end{array}$ \\
\hline LAWA195 & $\begin{array}{l}\sim 0.1 \text { vol\% of a } \\
\text { Cr-Zn and possibly Al and } \mathrm{Mg} \\
\text { spinel }\end{array}$ & $\begin{array}{c}\sim 3.6 \text { vol.\% of a Cr-sodalite and a Sn-sodium } \\
\text { zirconium silicate }\end{array}$ & opaque with dendritic structures \\
\hline LAWA196 & $\begin{array}{c}\text { clear green glass with } \\
\text { entrapped bubbles }\end{array}$ & clear green glass & $\begin{array}{l}\text { clear green glass with dendritic phase from } \\
\text { bottom to bulk }\end{array}$ \\
\hline LAWA197 & $\begin{array}{l}\text { moderate optical clarity; } \\
\sim 1 \text { vol\% metallic looking } \\
\text { nodules }\end{array}$ & clear green glass with fine particulates & dark green regions with small red regions \\
\hline
\end{tabular}


Table 2.6. Measured Compositions (wt \%) of Twenty Seven New LAW Envelope A Crucible Glasses Remelted with 4 wt\% Excess $\mathrm{SO}_{3}$.

\begin{tabular}{|c|c|c|c|c|c|c|c|c|c|c|c|c|c|c|c|c|c|c|}
\hline \multirow{2}{*}{ Oxides } & \multicolumn{2}{|c|}{ LAWA171S4 } & \multicolumn{2}{|c|}{ LAWA172S4 } & \multicolumn{2}{|c|}{ LAWA173S4 } & \multicolumn{2}{|c|}{ LAWA174S4 } & \multicolumn{2}{|c|}{ LAWA175S4 } & \multicolumn{2}{|c|}{ LAWA176S4 } & \multicolumn{2}{|c|}{ LAWA177S4 } & \multicolumn{2}{|c|}{ LAWA178S4 } & \multicolumn{2}{|c|}{ LAWA179S4 } \\
\hline & XRF & $\begin{array}{c}\text { XRF } \\
\text { after } \\
\text { washing }\end{array}$ & XRF & $\begin{array}{c}\text { XRF } \\
\text { after } \\
\text { washing }\end{array}$ & XRF & $\begin{array}{c}\text { XRF } \\
\text { after } \\
\text { washing }\end{array}$ & XRF & $\begin{array}{c}\text { XRF } \\
\text { after } \\
\text { washing }\end{array}$ & XRF & $\begin{array}{c}\text { XRF } \\
\text { after } \\
\text { washing }\end{array}$ & XRF & $\begin{array}{c}\text { XRF } \\
\text { after } \\
\text { washing }\end{array}$ & XRF & $\begin{array}{c}\text { XRF } \\
\text { after } \\
\text { washing }\end{array}$ & XRF & $\begin{array}{c}\text { XRF } \\
\text { after } \\
\text { washing }\end{array}$ & XRF & $\begin{array}{c}\text { XRF } \\
\text { after } \\
\text { washing }\end{array}$ \\
\hline $\mathrm{Al}_{2} \mathrm{O}_{3}$ & 10.03 & 10.60 & 10.57 & 11.13 & 10.34 & 10.87 & 10.25 & 10.97 & 11.95 & 12.35 & 13.61 & 13.93 & 10.04 & 10.52 & 10.61 & 11.13 & 10.48 & 10.95 \\
\hline $\mathrm{B}_{2} \mathrm{O}_{3}$ & $\mathrm{NA}^{*}$ & $\mathrm{NA}^{*}$ & $\mathrm{NA}^{*}$ & $\mathrm{NA}^{*}$ & $\mathrm{NA}^{*}$ & $\mathrm{NA}^{*}$ & $\mathrm{NA}^{*}$ & $\mathrm{NA}^{*}$ & $\mathrm{NA}^{*}$ & $\mathrm{NA}^{*}$ & $\mathrm{NA}^{*}$ & $\mathrm{NA}^{*}$ & $\mathrm{NA}^{*}$ & $\mathrm{NA}^{*}$ & $\mathrm{NA}^{*}$ & $\mathrm{NA}^{*}$ & $\mathrm{NA}^{*}$ & $\mathrm{NA}^{*}$ \\
\hline $\mathrm{CaO}$ & 5.42 & 5.40 & 7.43 & 7.74 & 7.79 & 7.71 & 7.54 & 7.79 & 7.36 & 7.57 & 7.31 & 7.53 & 3.57 & 3.42 & 7.83 & 7.48 & 7.76 & 7.76 \\
\hline $\mathrm{Cr}_{2} \mathrm{O}_{3}$ & 0.03 & 0.03 & 0.02 & 0.02 & 0.03 & 0.03 & 0.01 & 0.02 & 0.02 & 0.02 & 0.01 & 0.01 & 0.03 & 0.02 & 0.03 & 0.02 & 0.02 & 0.02 \\
\hline $\mathrm{Fe}_{2} \mathrm{O}_{3}$ & 1.07 & 1.07 & 0.92 & 0.99 & 1.01 & 0.99 & 0.95 & 1.00 & 0.89 & 0.94 & 0.89 & 0.94 & 1.07 & 1.03 & 0.99 & 0.94 & 0.97 & 0.97 \\
\hline $\mathrm{K}_{2} \mathrm{O}$ & 0.50 & 0.49 & 0.45 & 0.46 & 0.44 & 0.45 & 0.44 & 0.46 & 0.46 & 0.46 & 0.44 & 0.44 & 0.54 & 0.52 & 0.51 & 0.49 & 0.48 & 0.48 \\
\hline $\mathrm{MgO}$ & 1.03 & 0.88 & 0.86 & 0.77 & 0.97 & 0.80 & 0.97 & 0.84 & 0.95 & 0.84 & 0.95 & 0.82 & 1.00 & 1.07 & 0.95 & 0.92 & 0.94 & 0.94 \\
\hline $\mathrm{Na}_{2} \mathrm{O}$ & 23.48 & 21.79 & 23.94 & 21.48 & 23.42 & 22.02 & 24.39 & 21.72 & 23.84 & 22.29 & 23.49 & 22.49 & 24.97 & 24.17 & 25.31 & 24.39 & 25.77 & 23.66 \\
\hline $\mathrm{SiO}_{2}$ & 38.12 & 39.38 & 36.84 & 38.16 & 36.24 & 37.58 & 36.13 & 38.18 & 37.27 & 37.91 & 37.73 & 38.13 & 38.40 & 39.37 & 36.98 & 38.01 & 36.81 & 38.04 \\
\hline $\mathrm{SnO}_{2}$ & 0.00 & 0.01 & 0.00 & 0.01 & 0.01 & 0.01 & 0.01 & 0.01 & 0.01 & 0.01 & 0.01 & 0.00 & 0.00 & 0.00 & 0.01 & 0.01 & 0.01 & 0.00 \\
\hline $\mathrm{V}_{2} \mathrm{O}_{5}$ & 1.15 & 1.14 & 1.06 & 1.12 & 1.15 & 1.12 & 1.07 & 1.14 & 1.06 & 1.08 & 1.03 & 1.08 & 1.13 & 1.09 & 1.09 & 1.03 & 1.07 & 1.07 \\
\hline $\mathrm{ZnO}$ & 2.92 & 2.89 & 2.78 & 2.97 & 3.03 & 2.97 & 2.86 & 2.94 & 2.68 & 2.84 & 2.68 & 2.80 & 2.90 & 2.75 & 2.34 & 2.23 & 2.33 & 2.31 \\
\hline $\mathrm{ZrO}_{2}$ & 3.11 & 3.21 & 2.99 & 2.98 & 5.00 & 4.86 & 6.27 & 5.75 & 2.91 & 3.09 & 2.96 & 2.91 & 3.12 & 2.90 & 2.93 & 3.05 & 4.51 & 4.98 \\
\hline $\mathrm{Cl}$ & 0.38 & 0.38 & 0.25 & 0.24 & 0.24 & 0.22 & 0.32 & 0.33 & 0.35 & 0.34 & 0.25 & 0.23 & 0.37 & 0.36 & 0.34 & 0.33 & 0.36 & 0.36 \\
\hline $\mathrm{P}_{2} \mathrm{O}_{5}$ & 0.00 & 0.00 & 0.00 & 0.00 & 0.00 & 0.00 & 0.00 & 0.02 & 0.00 & 0.00 & 0.00 & 0.01 & 0.01 & 0.01 & 0.00 & 0.00 & 0.01 & 0.01 \\
\hline $\mathrm{SO}_{3}$ & 0.97 & 0.94 & 1.03 & 1.01 & 0.95 & 0.93 & 0.82 & 0.83 & 0.98 & 0.96 & 0.97 & 0.96 & 1.08 & 1.02 & 1.21 & 1.06 & 1.01 & 0.98 \\
\hline SUM & 101.9 & 101.9 & 101.9 & 101.9 & 101.9 & 101.8 & 101.8 & 101.8 & 102.0 & 102.0 & 102.1 & 102.1 & 101.9 & 101.9 & 101.9 & 101.8 & 101.8 & 101.8 \\
\hline
\end{tabular}


Table 2.6. Measured Compositions (wt \%) of Twenty Seven New LAW Envelope A Crucible Glasses Remelted with 4 wt \% Excess $\mathrm{SO}_{3}$ (continued).

\begin{tabular}{|c|c|c|c|c|c|c|c|c|c|c|c|c|c|c|c|c|c|c|}
\hline \multirow{2}{*}{ Oxides } & \multicolumn{2}{|c|}{ LAWA180S4 } & \multicolumn{2}{|c|}{ LAWA181S4 } & \multicolumn{2}{|c|}{ LAWA182S4 } & \multicolumn{2}{|c|}{ LAWA183S4 } & \multicolumn{2}{|c|}{ LAWA184S4 } & \multicolumn{2}{|c|}{ LAWA185S4 } & \multicolumn{2}{|c|}{ LAWA186S4 } & \multicolumn{2}{|c|}{ LAWA187S4 } & \multicolumn{2}{|c|}{ LAWA188S4 } \\
\hline & XRF & $\begin{array}{c}\text { XRF } \\
\text { after } \\
\text { washing }\end{array}$ & XRF & $\begin{array}{c}\text { XRF } \\
\text { after } \\
\text { washing }\end{array}$ & XRF & $\begin{array}{c}\text { XRF } \\
\text { after } \\
\text { washing }\end{array}$ & XRF & $\begin{array}{c}\text { XRF } \\
\text { after } \\
\text { washing }\end{array}$ & XRF & $\begin{array}{c}\text { XRF } \\
\text { after } \\
\text { washing }\end{array}$ & XRF & $\begin{array}{c}\text { XRF } \\
\text { after } \\
\text { washing }\end{array}$ & XRF & $\begin{array}{c}\text { XRF } \\
\text { after } \\
\text { washing }\end{array}$ & XRF & $\begin{array}{c}\text { XRF } \\
\text { after } \\
\text { washing }\end{array}$ & XRF & $\begin{array}{c}\text { XRF } \\
\text { after } \\
\text { washing }\end{array}$ \\
\hline $\mathrm{Al}_{2} \mathrm{O}_{3}$ & 10.61 & 11.03 & 12.11 & 12.60 & 13.50 & 14.16 & 11.26 & 11.53 & 11.31 & 11.48 & 12.93 & 13.11 & 12.35 & 12.46 & 10.71 & 10.82 & 10.86 & 10.80 \\
\hline $\mathrm{B}_{2} \mathrm{O}_{3}$ & $\mathrm{NA}^{*}$ & $\mathrm{NA}^{*}$ & $\mathrm{NA}^{*}$ & $\mathrm{NA}^{*}$ & $\mathrm{NA}^{*}$ & $\mathrm{NA}^{*}$ & $\mathrm{NA}^{*}$ & $\mathrm{NA}^{*}$ & $\mathrm{NA}^{*}$ & $\mathrm{NA}^{*}$ & $\mathrm{NA}^{*}$ & $\mathrm{NA}^{*}$ & $\mathrm{NA}^{*}$ & $\mathrm{NA}^{*}$ & $\mathrm{NA}^{*}$ & $\mathrm{NA}^{*}$ & $\mathrm{NA}^{*}$ & $\mathrm{NA}^{*}$ \\
\hline $\mathrm{CaO}$ & 7.88 & 7.94 & 7.70 & 7.74 & 7.53 & 7.67 & 7.86 & 7.81 & 7.23 & 7.49 & 7.61 & 7.76 & 7.65 & 8.02 & 5.92 & 6.47 & 5.21 & 5.32 \\
\hline $\mathrm{Cr}_{2} \mathrm{O}_{3}$ & 0.02 & 0.02 & 0.02 & 0.02 & 0.03 & 0.02 & 0.02 & 0.02 & 0.01 & 0.02 & 0.02 & 0.02 & 0.02 & 0.02 & 0.48 & 0.55 & 0.48 & 0.51 \\
\hline $\mathrm{Fe}_{2} \mathrm{O}_{3}$ & 0.95 & 0.98 & 0.95 & 0.97 & 0.95 & 1.00 & 0.98 & 1.00 & 0.91 & 0.97 & 0.91 & 0.96 & 0.92 & 1.00 & 0.90 & 1.01 & 0.93 & 0.99 \\
\hline $\mathrm{K}_{2} \mathrm{O}$ & 0.46 & 0.45 & 0.50 & 0.49 & 0.47 & 0.48 & 0.49 & 0.49 & 0.49 & 0.48 & 0.46 & 0.47 & 0.49 & 0.49 & 0.47 & 0.49 & 0.48 & 0.49 \\
\hline $\mathrm{MgO}$ & 0.97 & 0.97 & 0.95 & 0.89 & 1.05 & 0.90 & 0.78 & 0.79 & 0.82 & 0.77 & 0.84 & 0.76 & 0.78 & 0.72 & 0.85 & 0.75 & 0.78 & 0.76 \\
\hline $\mathrm{Na}_{2} \mathrm{O}$ & 25.42 & 23.54 & 25.71 & 23.77 & 26.24 & 24.17 & 20.49 & 19.94 & 21.12 & 20.36 & 21.36 & 20.21 & 20.83 & 19.62 & 23.61 & 20.98 & 22.20 & 21.40 \\
\hline $\mathrm{SiO}_{2}$ & 37.07 & 37.66 & 36.98 & 38.14 & 36.91 & 38.02 & 37.99 & 38.16 & 40.21 & 39.92 & 40.30 & 40.80 & 40.65 & 40.56 & 37.27 & 38.00 & 37.98 & 37.98 \\
\hline $\mathrm{SnO}_{2}$ & 0.01 & 0.01 & 0.01 & 0.00 & 0.01 & 0.01 & 0.01 & 0.00 & 0.00 & 0.01 & 0.01 & 0.01 & 0.00 & 0.00 & 1.13 & 1.26 & 2.15 & 2.38 \\
\hline $\mathrm{V}_{2} \mathrm{O}_{5}$ & 1.04 & 1.05 & 1.07 & 1.07 & 1.06 & 1.05 & 1.70 & 1.75 & 1.63 & 1.74 & 1.63 & 1.72 & 1.67 & 1.77 & 1.04 & 1.18 & 1.10 & 1.15 \\
\hline $\mathrm{ZnO}$ & 2.26 & 2.33 & 2.27 & 2.32 & 2.22 & 2.34 & 2.88 & 2.92 & 1.33 & 1.41 & 1.80 & 1.88 & 1.34 & 1.46 & 2.66 & 3.07 & 2.78 & 2.96 \\
\hline $\mathrm{ZrO}_{2}$ & 6.09 & 6.85 & 3.02 & 3.29 & 3.01 & 3.16 & 6.49 & 6.61 & 6.11 & 6.56 & 3.09 & 3.29 & 4.61 & 5.27 & 2.93 & 3.37 & 2.97 & 3.29 \\
\hline $\mathrm{Cl}$ & 0.28 & 0.28 & 0.38 & 0.38 & 0.32 & 0.32 & 0.34 & 0.33 & 0.38 & 0.38 & 0.36 & 0.35 & 0.36 & 0.33 & 0.33 & 0.34 & 0.36 & 0.34 \\
\hline $\mathrm{P}_{2} \mathrm{O}_{5}$ & 0.00 & 0.01 & 0.01 & 0.00 & 0.00 & 0.01 & 0.02 & 0.00 & 0.01 & 0.01 & 0.00 & 0.00 & 0.00 & 0.01 & 0.00 & 0.01 & 0.00 & 0.00 \\
\hline $\mathrm{SO}_{3}$ & 0.93 & 0.87 & 1.02 & 1.01 & 1.01 & 0.98 & 0.74 & 0.70 & 0.70 & 0.68 & 0.79 & 0.73 & 0.79 & 0.73 & 0.86 & 0.84 & 0.86 & 0.77 \\
\hline SUM & 101.7 & 101.7 & 102.0 & 101.9 & 102.1 & 102.1 & 101.8 & 101.8 & 101.7 & 101.7 & 101.9 & 101.9 & 101.8 & 101.8 & 101.9 & 101.9 & 101.9 & 101.9 \\
\hline
\end{tabular}

* Not analyzed; target values used in sums. 
Table 2.6. Measured Compositions (wt \%) of Twenty Seven New LAW Envelope A Crucible Glasses Remelted with 4 wt \% Excess $\mathrm{SO}_{3}$ (continued).

\begin{tabular}{|c|c|c|c|c|c|c|c|c|c|c|c|c|c|c|c|c|c|c|}
\hline \multirow{2}{*}{ Oxides } & \multicolumn{2}{|c|}{ LAWA189S4 } & \multicolumn{2}{|c|}{ LAWA190S4 } & \multicolumn{2}{|c|}{ LAWA191S4 } & \multicolumn{2}{|c|}{ LAWA192S4 } & \multicolumn{2}{|c|}{ LAWA193S4 } & \multicolumn{2}{|c|}{ LAWA194S4 } & \multicolumn{2}{|c|}{ LAWA195S4 } & \multicolumn{2}{|c|}{ LAWA196S4 } & \multicolumn{2}{|c|}{ LAWA197S4 } \\
\hline & XRF & $\begin{array}{c}\text { XRF } \\
\text { after } \\
\text { washing }\end{array}$ & XRF & $\begin{array}{c}\text { XRF } \\
\text { after } \\
\text { washing }\end{array}$ & XRF & $\begin{array}{c}\text { XRF } \\
\text { after } \\
\text { washing }\end{array}$ & XRF & $\begin{array}{c}\text { XRF } \\
\text { after } \\
\text { washing }\end{array}$ & XRF & $\begin{array}{c}\text { XRF } \\
\text { after } \\
\text { washing }\end{array}$ & XRF & $\begin{array}{c}\text { XRF } \\
\text { after } \\
\text { washing }\end{array}$ & XRF & $\begin{array}{c}\text { XRF } \\
\text { after } \\
\text { washing }\end{array}$ & XRF & $\begin{array}{c}\text { XRF } \\
\text { after } \\
\text { washing }\end{array}$ & XRF & $\begin{array}{c}\text { XRF } \\
\text { after } \\
\text { washing }\end{array}$ \\
\hline $\mathrm{Al}_{2} \mathrm{O}_{3}$ & 10.57 & 10.81 & 12.35 & 12.45 & 12.17 & 12.55 & 12.30 & 12.41 & 12.14 & 12.49 & 10.86 & 10.92 & 10.83 & 11.02 & 12.01 & 12.05 & 12.00 & 12.19 \\
\hline $\mathrm{B}_{2} \mathrm{O}_{3}$ & $\mathrm{NA}^{*}$ & $\mathrm{NA}^{*}$ & $\mathrm{NA}^{*}$ & $\mathrm{NA}^{*}$ & $\mathrm{NA}^{*}$ & $\mathrm{NA}^{*}$ & $\mathrm{NA}^{*}$ & $\mathrm{NA}^{*}$ & $\mathrm{NA}^{*}$ & $\mathrm{NA}^{*}$ & $\mathrm{NA}^{*}$ & $\mathrm{NA}^{*}$ & $\mathrm{NA}^{*}$ & $\mathrm{NA}^{*}$ & $\mathrm{NA}^{*}$ & $\mathrm{NA}^{*}$ & $\mathrm{NA}^{*}$ & $\mathrm{NA}^{*}$ \\
\hline $\mathrm{CaO}$ & 7.03 & 7.28 & 5.75 & 5.93 & 7.14 & 7.33 & 5.60 & 5.77 & 5.29 & 5.30 & 6.53 & 6.77 & 6.18 & 6.24 & 5.60 & 6.05 & 5.19 & 5.31 \\
\hline $\mathrm{Cr}_{2} \mathrm{O}_{3}$ & 0.47 & 0.51 & 0.47 & 0.50 & 0.49 & 0.51 & 0.01 & 0.02 & 0.50 & 0.50 & 0.02 & 0.02 & 0.47 & 0.47 & 0.02 & 0.02 & 0.46 & 0.49 \\
\hline $\mathrm{Fe}_{2} \mathrm{O}_{3}$ & 0.92 & 0.98 & 0.94 & 1.00 & 0.93 & 0.99 & 0.91 & 0.98 & 0.94 & 0.96 & 0.90 & 0.97 & 0.93 & 0.96 & 0.90 & 1.01 & 0.90 & 0.95 \\
\hline $\mathrm{K}_{2} \mathrm{O}$ & 0.46 & 0.47 & 0.49 & 0.49 & 0.49 & 0.50 & 0.48 & 0.49 & 0.48 & 0.48 & 0.48 & 0.49 & 0.49 & 0.48 & 0.48 & 0.51 & 0.48 & 0.49 \\
\hline $\mathrm{MgO}$ & 0.85 & 0.75 & 0.71 & 0.77 & 0.87 & 0.73 & 0.85 & 0.76 & 0.89 & 0.74 & 0.89 & 0.87 & 0.83 & 0.87 & 0.86 & 0.67 & 0.88 & 0.91 \\
\hline $\mathrm{Na}_{2} \mathrm{O}$ & 23.45 & 21.56 & 22.59 & 20.91 & 23.12 & 21.15 & 22.95 & 21.79 & 23.13 & 21.96 & 25.46 & 24.10 & 24.73 & 24.39 & 24.98 & 22.98 & 25.10 & 23.85 \\
\hline $\mathrm{SiO}_{2}$ & 37.25 & 38.04 & 37.81 & 38.34 & 37.30 & 38.28 & 38.77 & 38.95 & 38.16 & 38.91 & 37.72 & 37.84 & 37.77 & 37.89 & 39.07 & 39.37 & 39.00 & 38.98 \\
\hline $\mathrm{SnO}_{2}$ & 0.01 & 0.01 & 0.01 & 0.01 & 0.00 & 0.01 & 0.00 & 0.01 & 0.00 & 0.00 & 1.05 & 1.17 & 1.15 & 1.11 & 0.01 & 0.02 & 0.00 & 0.01 \\
\hline $\mathrm{V}_{2} \mathrm{O}_{5}$ & 1.08 & 1.14 & 1.10 & 1.15 & 1.11 & 1.15 & 1.05 & 1.13 & 1.10 & 1.12 & 1.01 & 1.07 & 1.03 & 1.05 & 0.99 & 1.12 & 1.01 & 1.05 \\
\hline $\mathrm{ZnO}$ & 2.78 & 2.94 & 2.80 & 2.98 & 2.83 & 2.94 & 2.72 & 2.89 & 2.82 & 2.86 & 2.13 & 2.29 & 2.22 & 2.28 & 2.11 & 2.38 & 2.10 & 2.28 \\
\hline $\mathrm{ZrO}_{2}$ & 4.59 & 5.00 & 4.50 & 5.05 & 3.09 & 3.43 & 3.90 & 4.39 & 4.13 & 4.27 & 5.78 & 6.36 & 6.11 & 6.24 & 5.78 & 6.65 & 5.68 & 6.52 \\
\hline $\mathrm{Cl}$ & 0.32 & 0.32 & 0.39 & 0.37 & 0.37 & 0.37 & 0.35 & 0.33 & 0.37 & 0.37 & 0.39 & 0.38 & 0.40 & 0.37 & 0.41 & 0.41 & 0.39 & 0.36 \\
\hline $\mathrm{P}_{2} \mathrm{O}_{5}$ & 0.02 & 0.01 & 0.00 & 0.01 & 0.00 & 0.00 & 0.00 & 0.00 & 0.00 & 0.00 & 0.01 & 0.00 & 0.01 & 0.00 & 0.01 & 0.00 & 0.01 & 0.02 \\
\hline $\mathrm{SO}_{3}$ & 0.80 & 0.76 & 0.78 & 0.72 & 0.80 & 0.78 & 0.79 & 0.75 & 0.74 & 0.71 & 0.76 & 0.72 & 0.83 & 0.64 & 0.78 & 0.76 & 0.82 & 0.64 \\
\hline SUM & 101.9 & 101.9 & 102.0 & 102.0 & 102.0 & 102.0 & 102.0 & 101.9 & 102.0 & 102.0 & 101.7 & 101.7 & 101.7 & 101.8 & 101.8 & 101.8 & 101.8 & 101.8 \\
\hline
\end{tabular}


Table 2.7. Results of 7-day PCT (at $90^{\circ} \mathrm{C}$ ) and VHT (at $200^{\circ} \mathrm{C}$ for 24 Days (g/m²/day)) for Twenty Seven New LAW Envelope A Crucible Glasses.

\begin{tabular}{|c|c|c|c|c|c|c|c|c|c|c|c|c|c|c|}
\hline Glass ID & $\begin{array}{l}\text { LAW } \\
\text { A171 }\end{array}$ & $\begin{array}{l}\text { LAW } \\
\text { A172 }\end{array}$ & $\begin{array}{l}\text { LAW } \\
\text { A173 }\end{array}$ & $\begin{array}{l}\text { LAW } \\
\text { A174 }\end{array}$ & $\begin{array}{l}\text { LAW } \\
\text { A175 }\end{array}$ & $\begin{array}{l}\text { LAW } \\
\text { A176 }\end{array}$ & $\begin{array}{l}\text { LAW } \\
\text { A177 }\end{array}$ & $\begin{array}{l}\text { LAW } \\
\text { A178 }\end{array}$ & $\begin{array}{l}\text { LAW } \\
\text { A179 }\end{array}$ & $\begin{array}{l}\text { LAW } \\
\text { A180 }\end{array}$ & $\begin{array}{l}\text { LAW } \\
\text { A181 }\end{array}$ & $\begin{array}{l}\text { LAW } \\
\text { A182 }\end{array}$ & $\begin{array}{l}\text { LAW } \\
\text { A183 }\end{array}$ & $\begin{array}{l}\text { LAW } \\
\text { A184 }\end{array}$ \\
\hline \multicolumn{15}{|c|}{ 7-Day PCT, Stainless Steel Vessel; $\mathbf{S} / \mathrm{V}=2000 \mathrm{~m}^{-1} \quad(\mathrm{ppm})$} \\
\hline B & 111.50 & 67.81 & 68.65 & 58.50 & 61.91 & 26.25 & 283.40 & 100.30 & 68.88 & 48.68 & 58.53 & 28.05 & 34.30 & 35.40 \\
\hline $\mathrm{Na}$ & 349.70 & 275.30 & 318.20 & 382.70 & 366.20 & 234.40 & 864.20 & 630.70 & 542.10 & 545.00 & 510.20 & 420.60 & 172.30 & 210.70 \\
\hline $\mathrm{Si}$ & 70.80 & 63.13 & 68.84 & 66.86 & 71.55 & 51.57 & 115.30 & 129.50 & 104.10 & 103.00 & 108.30 & 93.27 & 41.61 & 52.04 \\
\hline \multicolumn{15}{|c|}{ Normalized Concentrations (g/L) } \\
\hline B & 2.63 & 1.71 & 1.96 & 1.92 & 1.77 & 0.86 & 6.68 & 3.00 & 2.40 & 2.02 & 2.04 & 1.16 & 1.13 & 1.21 \\
\hline $\mathrm{Na}$ & 2.05 & 1.61 & 1.86 & 2.24 & 2.15 & 1.37 & 4.66 & 3.40 & 2.92 & 2.94 & 2.75 & 2.27 & 1.01 & 1.23 \\
\hline Si & 0.41 & 0.39 & 0.42 & 0.41 & 0.44 & 0.32 & 0.67 & 0.78 & 0.63 & 0.62 & 0.66 & 0.57 & 0.26 & 0.30 \\
\hline $\mathrm{pH}$ & 11.48 & 11.58 & 11.75 & 11.80 & 11.70 & 11.61 & 11.88 & 12.09 & 12.07 & 12.15 & 12.08 & 12.08 & 11.35 & 11.43 \\
\hline \multicolumn{15}{|c|}{ 7-Day PCT Normalized Mass Loss $\left(\mathrm{g} / \mathrm{m}^{2}\right)$} \\
\hline $\mathrm{B}$ & 1.31 & 0.85 & 0.98 & 0.96 & 0.88 & 0.43 & 3.34 & 1.50 & 1.20 & 1.01 & 1.02 & 0.58 & 0.56 & 0.61 \\
\hline $\mathrm{Na}$ & 1.02 & 0.81 & 0.93 & 1.12 & 1.07 & 0.69 & 2.33 & 1.70 & 1.46 & 1.47 & 1.38 & 1.13 & 0.50 & 0.62 \\
\hline $\mathrm{Si}$ & 0.21 & 0.19 & 0.21 & 0.21 & 0.22 & 0.16 & 0.34 & 0.39 & 0.32 & 0.31 & 0.33 & 0.28 & 0.13 & 0.15 \\
\hline \multicolumn{15}{|c|}{ 7-Day PCT Normalized Loss Rate (g/m²/d) } \\
\hline $\mathrm{B}$ & 0.19 & 0.12 & 0.14 & 0.14 & 0.13 & 0.06 & 0.48 & 0.21 & 0.17 & 0.14 & 0.15 & 0.08 & 0.08 & 0.09 \\
\hline $\mathrm{Na}$ & 0.15 & 0.12 & 0.13 & 0.16 & 0.15 & 0.10 & 0.33 & 0.24 & 0.21 & 0.21 & 0.20 & 0.16 & 0.07 & 0.09 \\
\hline $\mathrm{Si}$ & 0.03 & 0.03 & 0.03 & 0.03 & 0.03 & 0.02 & 0.05 & 0.06 & 0.05 & 0.04 & 0.05 & 0.04 & 0.02 & 0.02 \\
\hline \multicolumn{15}{|c|}{ VHT Alteration (24 days at $200^{\circ} \mathrm{C}$ ) } \\
\hline Alteration depth $(\mu \mathrm{m})$ & $\begin{array}{l}\text { Coupon } \\
\text { fully } \\
\text { reacted }\end{array}$ & $\begin{array}{l}\text { Coupon } \\
\text { fully } \\
\text { reacted }\end{array}$ & 696 & 251 & 415 & 152 & $\begin{array}{l}\text { Coupon } \\
\text { fully } \\
\text { reacted }\end{array}$ & $\begin{array}{l}\text { Coupon } \\
\text { fully } \\
\text { reacted }\end{array}$ & $\begin{array}{c}\text { Coupon } \\
\text { fully } \\
\text { reacted }\end{array}$ & 585 & $\begin{array}{l}\text { Coupon } \\
\text { fully } \\
\text { reacted }\end{array}$ & $\begin{array}{l}\text { Coupon } \\
\text { fully } \\
\text { reacted }\end{array}$ & 230 & 70 \\
\hline $\begin{array}{l}\text { Alteration Rate (g/m²/day) } \\
\text { calculated using measured } \\
\text { density }\end{array}$ & $>>100$ & $>>100$ & 77 & 28 & 45 & 17 & $>>100$ & $>>100$ & $>>100$ & 65 & $>>100$ & $>>100$ & 26 & 8 \\
\hline
\end{tabular}


Table 2.7. Results of 7-day PCT (at $90^{\circ} \mathrm{C}$ ) and VHT (at $200^{\circ} \mathrm{C}$ for 24 Days (g/m²/day)) for for Twenty Seven New LAW Envelope A Crucible Glasses (continued).

\begin{tabular}{|c|c|c|c|c|c|c|c|c|c|c|c|c|c|}
\hline Glass ID & $\begin{array}{l}\text { LAW } \\
\text { A185 }\end{array}$ & $\begin{array}{l}\text { LAW } \\
\text { A186 }\end{array}$ & $\begin{array}{l}\text { LAW } \\
\text { A187 }\end{array}$ & $\begin{array}{l}\text { LAW } \\
\text { A188 }\end{array}$ & $\begin{array}{l}\text { LAW } \\
\text { A189 }\end{array}$ & $\begin{array}{l}\text { LAW } \\
\text { A190 }\end{array}$ & $\begin{array}{l}\text { LAW } \\
\text { A191 }\end{array}$ & $\begin{array}{l}\text { LAW } \\
\text { A192 }\end{array}$ & $\begin{array}{l}\text { LAW } \\
\text { A193 }\end{array}$ & $\begin{array}{l}\text { LAW } \\
\text { A194 }\end{array}$ & $\begin{array}{l}\text { LAW } \\
\text { A195 }\end{array}$ & $\begin{array}{l}\text { LAW } \\
\text { A196 }\end{array}$ & $\begin{array}{l}\text { LAW } \\
\text { A197 }\end{array}$ \\
\hline \multicolumn{14}{|c|}{ 7-Day PCT, Stainless Steel Vessel; S/V=2000m ${ }^{-1}$} \\
\hline B & 22.75 & 24.80 & 136.00 & 132.10 & 81.74 & 91.01 & 74.74 & 77.80 & 96.22 & 45.02 & 51.15 & 36.52 & 37.60 \\
\hline $\mathrm{Na}$ & 166.80 & 182.00 & 499.00 & 444.90 & 403.90 & 387.50 & 386.30 & 335.50 & 417.80 & 504.00 & 525.30 & 354.20 & $\begin{array}{r}362.1 \\
0 \\
\end{array}$ \\
\hline Si & 50.35 & 49.77 & 79.87 & 70.96 & 71.40 & 63.19 & 71.14 & 63.51 & 68.90 & 82.73 & 84.51 & 67.37 & 68.69 \\
\hline \multicolumn{14}{|c|}{ Normalized Concentrations (g/L) } \\
\hline B & 0.75 & 0.86 & 3.42 & 3.33 & 2.33 & 2.60 & 2.13 & 2.22 & 2.75 & 1.87 & 2.12 & 1.52 & 1.56 \\
\hline $\mathrm{Na}$ & 0.98 & 1.07 & 2.92 & 2.61 & 2.37 & 2.27 & 2.26 & 1.97 & 2.45 & 2.72 & 2.83 & 1.91 & 1.95 \\
\hline $\mathrm{Si}$ & 0.29 & 0.29 & 0.49 & 0.44 & 0.44 & 0.39 & 0.44 & 0.38 & 0.41 & 0.50 & 0.51 & 0.40 & 0.40 \\
\hline $\mathrm{pH}$ & 11.34 & 11.38 & 11.68 & 11.58 & 11.75 & 11.68 & 11.75 & 11.65 & 11.68 & 12.06 & 12.03 & 11.88 & 11.85 \\
\hline \multicolumn{14}{|c|}{ 7-Day PCT Normalized Mass Loss $\left(\mathrm{g} / \mathrm{m}^{2}\right)$} \\
\hline $\mathrm{B}$ & 0.37 & 0.43 & 1.71 & 1.66 & 1.17 & 1.30 & 1.07 & 1.11 & 1.37 & 0.93 & 1.06 & 0.76 & 0.78 \\
\hline $\mathrm{Na}$ & 0.49 & 0.53 & 1.46 & 1.30 & 1.18 & 1.14 & 1.13 & 0.98 & 1.22 & 1.36 & 1.42 & 0.95 & 0.98 \\
\hline $\mathrm{Si}$ & 0.15 & 0.14 & 0.25 & 0.22 & 0.22 & 0.19 & 0.22 & 0.19 & 0.21 & 0.25 & 0.26 & 0.20 & 0.20 \\
\hline \multicolumn{14}{|c|}{ 7-Day PCT Normalized Loss Rate $\left(\mathrm{g} / \mathrm{m}^{2} / \mathrm{d}\right)$} \\
\hline $\mathrm{B}$ & 0.05 & 0.06 & 0.24 & 0.24 & 0.17 & 0.19 & 0.15 & 0.16 & 0.20 & 0.13 & 0.15 & 0.11 & 0.11 \\
\hline $\mathrm{Na}$ & 0.07 & 0.08 & 0.21 & 0.19 & 0.17 & 0.16 & 0.16 & 0.14 & 0.17 & 0.19 & 0.20 & 0.14 & 0.14 \\
\hline $\mathrm{Si}$ & 0.02 & 0.02 & 0.04 & 0.03 & 0.03 & 0.03 & 0.03 & 0.03 & 0.03 & 0.04 & 0.04 & 0.03 & 0.03 \\
\hline \multicolumn{14}{|c|}{ VHT Alteration $\left(24\right.$ days at $\left.200^{\circ} \mathrm{C}\right)$} \\
\hline Alteration depth $(\mu \mathrm{m})$ & 129 & 90 & 230 & 96 & 135 & 239 & 171 & 252 & 207 & 207 & 229 & 712 & 212 \\
\hline $\begin{array}{l}\text { Alteration Rate (g/m²/day) } \\
\text { calculated using measured } \\
\text { density }\end{array}$ & 14 & 10 & 25 & 11 & 15 & 27 & 19 & 28 & 23 & 23 & 26 & 79 & 24 \\
\hline
\end{tabular}


Table 2.8. Viscosities and Electrical Conductivities of Twenty Seven New LAW Envelope A Crucible Glasses.

\begin{tabular}{|c|c|c|c|c|c|c|c|c|c|c|c|c|c|c|}
\hline Glass ID & $\begin{array}{c}\text { LAWA } \\
171\end{array}$ & $\begin{array}{c}\text { LAWA } \\
172\end{array}$ & $\begin{array}{c}\text { LAWA } \\
173\end{array}$ & $\begin{array}{c}\text { LAWA } \\
174\end{array}$ & $\begin{array}{c}\text { LAWA } \\
175\end{array}$ & $\begin{array}{c}\text { LAWA } \\
176\end{array}$ & $\begin{array}{c}\text { LAWA } \\
177\end{array}$ & $\begin{array}{c}\text { LAWA } \\
178\end{array}$ & $\begin{array}{c}\text { LAWA } \\
179\end{array}$ & $\begin{array}{c}\text { LAWA } \\
180\end{array}$ & $\begin{array}{c}\text { LAWA } \\
181\end{array}$ & $\begin{array}{c}\text { LAWA } \\
182\end{array}$ & $\begin{array}{c}\text { LAWA } \\
183\end{array}$ & $\begin{array}{l}\text { LAW } \\
\text { A184 }\end{array}$ \\
\hline \multicolumn{15}{|c|}{ Viscosity (poise) } \\
\hline $900^{\circ} \mathrm{C}$ & 356 & 308 & 501 & 838 & 441 & 773 & 278 & 351 & 525 & 868 & 553 & 970 & 1383 & 1789 \\
\hline $950^{\circ} \mathrm{C}$ & 170 & 149 & 223 & 349 & 209 & 352 & 142 & 170 & 237 & 379 & 260 & 440 & 557 & 703 \\
\hline $1000^{\circ} \mathrm{C}$ & 90 & 79 & 112 & 167 & 111 & 177 & 78 & 91 & 120 & 183 & 135 & 220 & 256 & 317 \\
\hline $1050^{\circ} \mathrm{C}$ & 52 & 46 & 62 & 88 & 64 & 97 & 47 & 53 & 68 & 97 & 75 & 120 & 131 & 160 \\
\hline $1100^{\circ} \mathrm{C}$ & 32 & 29 & 37 & 51 & 39 & 57 & 29 & 33 & 41 & 55 & 45 & 70 & 73 & 88 \\
\hline $1150^{\circ} \mathrm{C}$ & 21 & 19 & 24 & 32 & 26 & 35 & 19 & 22 & 26 & 33 & 28 & 43 & 43 & 52 \\
\hline $1200^{\circ} \mathrm{C}$ & 15 & 13 & 16 & 21 & 17 & 23 & 13 & 15 & 18 & 21 & 19 & 28 & 27 & 32 \\
\hline $1250^{\circ} \mathrm{C}$ & 10 & 9 & 11 & 14 & 12 & 16 & 10 & 11 & 13 & 14 & 13 & 19 & 18 & 21 \\
\hline \multicolumn{15}{|c|}{ Electrical Conductivity (S/cm) } \\
\hline $900^{\circ} \mathrm{C}$ & 0.221 & 0.213 & 0.206 & 0.197 & 0.207 & 0.213 & 0.288 & 0.227 & 0.244 & 0.261 & 0.281 & 0.276 & 0.139 & 0.124 \\
\hline $950^{\circ} \mathrm{C}$ & 0.279 & 0.267 & 0.266 & 0.255 & 0.267 & 0.274 & 0.370 & 0.323 & 0.324 & 0.324 & 0.348 & 0.342 & 0.181 & 0.177 \\
\hline $1000^{\circ} \mathrm{C}$ & 0.344 & 0.329 & 0.333 & 0.320 & 0.334 & 0.342 & 0.446 & 0.419 & 0.410 & 0.396 & 0.423 & 0.416 & 0.231 & 0.235 \\
\hline $1050^{\circ} \mathrm{C}$ & 0.416 & 0.399 & 0.408 & 0.391 & 0.408 & 0.415 & 0.516 & 0.515 & 0.499 & 0.476 & 0.506 & 0.498 & 0.288 & 0.297 \\
\hline $1100^{\circ} \mathrm{C}$ & 0.497 & 0.477 & 0.489 & 0.467 & 0.487 & 0.494 & 0.579 & 0.606 & 0.589 & 0.564 & 0.596 & 0.588 & 0.354 & 0.360 \\
\hline $1150^{\circ} \mathrm{C}$ & 0.585 & 0.563 & 0.576 & 0.548 & 0.572 & 0.576 & 0.637 & 0.693 & 0.678 & 0.661 & 0.695 & 0.686 & 0.428 & 0.424 \\
\hline $1200^{\circ} \mathrm{C}$ & 0.681 & 0.657 & 0.669 & 0.633 & 0.662 & 0.663 & 0.690 & 0.774 & 0.767 & 0.766 & 0.801 & 0.791 & 0.509 & 0.488 \\
\hline $1250^{\circ} \mathrm{C}$ & 0.784 & 0.759 & 0.767 & 0.721 & 0.755 & 0.752 & 0.738 & 0.851 & 0.854 & 0.880 & 0.915 & 0.904 & 0.599 & 0.551 \\
\hline
\end{tabular}


Table 2.8. Viscosities and Electrical Conductivities of Twenty Seven New LAW Envelope A Crucible Glasses (continued).

\begin{tabular}{|c|c|c|c|c|c|c|c|c|c|c|c|c|c|}
\hline Glass ID & $\begin{array}{c}\text { LAWA } \\
185\end{array}$ & $\begin{array}{c}\text { LAWA } \\
186\end{array}$ & $\begin{array}{c}\text { LAWA } \\
187\end{array}$ & $\begin{array}{c}\text { LAWA } \\
188\end{array}$ & $\begin{array}{c}\text { LAWA } \\
189\end{array}$ & $\begin{array}{c}\text { LAWA } \\
190\end{array}$ & $\begin{array}{c}\text { LAWA } \\
191\end{array}$ & $\begin{array}{c}\text { LAWA } \\
192\end{array}$ & $\begin{array}{c}\text { LAWA } \\
193\end{array}$ & $\begin{array}{c}\text { LAWA } \\
194\end{array}$ & $\begin{array}{c}\text { LAWA } \\
195\end{array}$ & $\begin{array}{c}\text { LAWA } \\
196\end{array}$ & $\begin{array}{c}\text { LAWA } \\
197\end{array}$ \\
\hline \multicolumn{14}{|c|}{ Viscosity (poise) } \\
\hline $900^{\circ} \mathrm{C}$ & 1295 & 1879 & 388 & 517 & 616 & 845 & 548 & 847 & 812 & 1222 & 1203 & 1534 & 1799 \\
\hline $950^{\circ} \mathrm{C}$ & 557 & 743 & 181 & 225 & 258 & 341 & 246 & 369 & 356 & 482 & 473 & 623 & 694 \\
\hline $1000^{\circ} \mathrm{C}$ & 269 & 339 & 94 & 113 & 126 & 163 & 125 & 183 & 176 & 219 & 215 & 288 & 310 \\
\hline $1050^{\circ} \mathrm{C}$ & 142 & 173 & 53 & 63 & 69 & 88 & 70 & 100 & 96 & 112 & 110 & 147 & 155 \\
\hline $1100^{\circ} \mathrm{C}$ & 81 & 97 & 33 & 38 & 41 & 52 & 43 & 59 & 56 & 62 & 61 & 82 & 85 \\
\hline $1150^{\circ} \mathrm{C}$ & 50 & 58 & 21 & 25 & 26 & 34 & 28 & 38 & 35 & 37 & 37 & 49 & 50 \\
\hline $1200^{\circ} \mathrm{C}$ & 32 & 37 & 14 & 17 & 18 & 23 & 19 & 25 & 23 & 24 & 23 & 31 & 32 \\
\hline $1250^{\circ} \mathrm{C}$ & 21 & 25 & 10 & 12 & 13 & 16 & 13 & 18 & 16 & 16 & 16 & 21 & 21 \\
\hline \multicolumn{14}{|c|}{ Electrical Conductivity (S/cm) } \\
\hline $900^{\circ} \mathrm{C}$ & 0.148 & 0.120 & 0.194 & 0.227 & 0.214 & 0.182 & 0.178 & 0.189 & 0.173 & 0.239 & 0.240 & 0.225 & 0.218 \\
\hline $950^{\circ} \mathrm{C}$ & 0.193 & 0.166 & 0.259 & 0.279 & 0.270 & 0.240 & 0.256 & 0.241 & 0.232 & 0.298 & 0.303 & 0.305 & 0.276 \\
\hline $1000^{\circ} \mathrm{C}$ & 0.244 & 0.217 & 0.328 & 0.338 & 0.334 & 0.306 & 0.332 & 0.300 & 0.296 & 0.356 & 0.375 & 0.391 & 0.343 \\
\hline $1050^{\circ} \mathrm{C}$ & 0.301 & 0.273 & 0.398 & 0.402 & 0.406 & 0.378 & 0.403 & 0.365 & 0.364 & 0.411 & 0.456 & 0.481 & 0.419 \\
\hline $1100^{\circ} \mathrm{C}$ & 0.362 & 0.331 & 0.470 & 0.473 & 0.487 & 0.456 & 0.468 & 0.436 & 0.436 & 0.463 & 0.545 & 0.573 & 0.504 \\
\hline $1150^{\circ} \mathrm{C}$ & 0.428 & 0.392 & 0.541 & 0.548 & 0.576 & 0.538 & 0.529 & 0.512 & 0.508 & 0.513 & 0.643 & 0.665 & 0.599 \\
\hline $1200^{\circ} \mathrm{C}$ & 0.498 & 0.455 & 0.611 & 0.629 & 0.675 & 0.624 & 0.584 & 0.594 & 0.582 & 0.560 & 0.750 & 0.758 & 0.703 \\
\hline $1250^{\circ} \mathrm{C}$ & 0.571 & 0.518 & 0.680 & 0.715 & 0.782 & 0.713 & 0.634 & 0.680 & 0.656 & 0.604 & 0.865 & 0.849 & 0.816 \\
\hline
\end{tabular}


Table 2.9. Measured Densities and Glass Transition Temperatures (by Differential Thermal Analysis) of Seventeen New LAW Envelope A Crucible Glasses.

\begin{tabular}{|c|c|c|}
\hline $\begin{array}{l}\text { Glass } \\
\text { Name }\end{array}$ & $\begin{array}{c}\text { Density } \\
20^{\circ} \mathrm{C}(\mathrm{g} / \mathrm{cc})\end{array}$ & $\mathrm{T}_{\mathrm{G}}\left({ }^{\circ} \mathrm{C}\right)$ \\
\hline LAWA171 & 2.609 & - \\
\hline LAWA172 & 2.636 & - \\
\hline LAWA173 & 2.665 & - \\
\hline LAWA174 & 2.675 & - \\
\hline LAWA175 & 2.631 & - \\
\hline LAWA176 & 2.639 & - \\
\hline LAWA177 & 2.640 & - \\
\hline LAWA178 & 2.630 & - \\
\hline LAWA179 & 2.646 & - \\
\hline LAWA180 & 2.676 & - \\
\hline LAWA181 & 2.625 & - \\
\hline LAWA182 & 2.631 & - \\
\hline LAWA183 & 2.695 & - \\
\hline LAWA184 & 2.652 & - \\
\hline LAWA185 & 2.623 & - \\
\hline LAWA186 & 2.622 & - \\
\hline LAWA187 & 2.626 & 579 \\
\hline LAWA188 & 2.641 & - \\
\hline LAWA189 & 2.645 & - \\
\hline LAWA190 & 2.639 & - \\
\hline LAWA191 & 2.629 & - \\
\hline LAWA192 & 2.635 & - \\
\hline LAWA193 & 2.627 & - \\
\hline LAWA194 & 2.673 & - \\
\hline LAWA195 & 2.673 & - \\
\hline LAWA196 & 2.657 & - \\
\hline LAWA197 & 2.654 & - \\
\hline
\end{tabular}

- Empty data field 
Table 2.10. Results of K-3 Corrosion Testing for Sixteen of the New LAW Envelope A Crucible Glasses.

\begin{tabular}{|l|c|c|c|}
\hline Glass ID & $\begin{array}{c}\text { Neck loss } \\
\text { (inches) }\end{array}$ & $\begin{array}{c}\text { Depth of altered } \\
\text { zone (inches) }\end{array}$ & $\begin{array}{c}\text { Half-down loss } \\
\text { (inches) }\end{array}$ \\
\hline LAWA173 & 0.121 & 0.032 & 0.003 \\
\hline LAWA175 & 0.081 & 0.028 & 0.001 \\
\hline LAWA176 & 0.065 & 0.028 & $\begin{array}{c}\text { Coupon expanded - } \\
\text { no measurable loss }\end{array}$ \\
\hline LAWA183 & 0.042 & 0.025 & 0.001 \\
\hline LAWA184 & 0.037 & 0.025 & 0.003 \\
\hline LAWA185 & 0.035 & 0.025 & 0.004 \\
\hline LAWA186 & 0.045 & 0.024 & 0.005 \\
\hline LAWA187 & 0.033 & 0.031 & 0.001 \\
\hline LAWA188 & 0.041 & 0.033 & 0.001 \\
\hline LAWA189 & 0.067 & 0.030 & 0.001 \\
\hline LAWA190 & 0.043 & 0.029 & $\begin{array}{c}\text { Coupon expanded - } \\
\text { no measurable loss }\end{array}$ \\
\hline LAWA191 & 0.052 & 0.031 & 0.001 \\
\hline LAWA192 & 0.052 & 0.027 & $\begin{array}{c}\text { Coupon expanded - } \\
\text { no measurable loss }\end{array}$ \\
\hline LAWA194 & 0.067 & 0.028 & 0.003 \\
\hline LAWA195 & 0.033 & 0.03 & measurable loss \\
\hline LAWA196 & 0.049 & 0.028 & 0.001 \\
\hline
\end{tabular}




\section{Table 2.11. Summary of Test Results for Selected Glass Formulation LAWA187 and Comparison to ILAW Requirements.}

\begin{tabular}{|l|c|c|}
\hline Test & Requirement * & $\begin{array}{c}\text { Test Result for } \\
\text { LAWA187 }\end{array}$ \\
\hline Density of glass & $<3.7 \mathrm{~g} / \mathrm{cc}$ & $2.626 \mathrm{~g} / \mathrm{cc}$ \\
\hline Crystalline Phase & Phase Identification & $\begin{array}{c}\text { Clear homogeneous glass } \\
\text { down to } 850^{\circ} \mathrm{C}\end{array}$ \\
\hline Liquidus & $<950^{\circ} \mathrm{C}$ & $<850^{\circ} \mathrm{C}$ \\
\hline Centerline Canister Cooling & Phase Identification & $\begin{array}{c}\text { Clear homogeneous glass at the center } \\
\text { of the sample with crystallization } \\
\text { towards the crucible contact }\end{array}$ \\
\hline PCT B (g/m $\left.{ }^{2}\right)$ & $<2.0 \mathrm{~g} / \mathrm{m}^{2}$ & $1.71 \mathrm{~g} / \mathrm{m}^{2}$ \\
\hline PCT Na (g/m $\left.{ }^{2}\right)$ & $<2.0 \mathrm{~g} / \mathrm{m}^{2}$ & $0.25 \mathrm{~g} / \mathrm{m}^{2}$ \\
\hline PCT Si $\left(\mathrm{g} / \mathrm{m}^{2}\right)$ & $<2.0 \mathrm{~g} / \mathrm{m}^{2}$ & $25 \mathrm{~g} / \mathrm{m}^{2} / \mathrm{day}$ \\
\hline VHT at $200^{\circ} \mathrm{C}\left(\mathrm{g} / \mathrm{m}^{2} / \mathrm{day}\right)$ & $<50 \mathrm{~g} / \mathrm{m}^{2} / \mathrm{day}$ & $33 \mathrm{P}$ \\
\hline Viscosity (poise) at $1100^{\circ} \mathrm{C}$ & 10 to $150 \mathrm{P}$ & $0.47 \mathrm{~S} / \mathrm{cm}^{2}$ \\
\hline Conductivity (S/cm) at $1100^{\circ} \mathrm{C}$ & 0.2 to $0.7 \mathrm{~S} / \mathrm{cm}$ & $579{ }^{\circ} \mathrm{C}$ \\
\hline T $\left({ }^{\circ} \mathrm{C}\right)$ & Report for modeling & \\
\hline
\end{tabular}

* - "Design, Construction, and Commissioning of the Hanford Tank Waste Treatment and Immobilization Plant", Contract Number: DE-AC27-01RV14136, Modification A029, U. S. Department of Energy, Office of River Protection, Richland WA, 2001, as amended. 


\section{Table 2.12. Oxide Composition of LAW Envelope A Simulant and Corresponding Glass Composition Used in Melter Tests (wt\%).}

\begin{tabular}{|c|c|c|c|}
\hline Component & $\begin{array}{l}\text { AN-105 waste } \\
\text { contribution }\end{array}$ & $\begin{array}{l}\text { Glass former } \\
\text { additives }\end{array}$ & $\begin{array}{l}\text { LAWA187 } \\
\text { (for AN-105) }\end{array}$ \\
\hline Loading & $30.46 \%$ & $69.54 \%$ & - \\
\hline $\mathrm{Al}_{2} \mathrm{O}_{3}$ & 5.284 & 5.29 & 10.57 \\
\hline $\mathrm{B}_{2} \mathrm{O}_{3}$ & 0.023 & 12.75 & 12.77 \\
\hline $\mathrm{CaO}$ & - & 6.47 & 6.47 \\
\hline $\mathrm{Cr}_{2} \mathrm{O}_{3}$ & 0.020 & 0.50 & 0.52 \\
\hline $\mathrm{Fe}_{2} \mathrm{O}_{3}$ & - & 0.90 & 0.90 \\
\hline $\mathrm{K}_{2} \mathrm{O}$ & 0.508 & - & 0.51 \\
\hline $\mathrm{MgO}$ & - & 0.90 & 0.90 \\
\hline $\mathrm{Na}_{2} \mathrm{O}^{(\mathrm{a})}$ & $22.69+0.11^{(1)}+0.20^{(2)}$ & - & 23.00 \\
\hline $\mathrm{SiO}_{2}$ & 0.031 & 34.77 & 34.80 \\
\hline $\mathrm{SnO}_{2}$ & & 1.00 & 1.00 \\
\hline $\mathrm{V}_{2} \mathrm{O}_{5}$ & - & 0.97 & 0.97 \\
\hline $\mathrm{ZnO}$ & - & 2.99 & 2.99 \\
\hline $\mathrm{ZrO}_{2}$ & - & 2.99 & 2.99 \\
\hline $\mathrm{Cl}$ & 0.640 & - & 0.64 \\
\hline $\mathrm{F}$ & 0.003 & - & 0.00 \\
\hline $\mathrm{P}_{2} \mathrm{O}_{5}$ & 0.000 & - & 0.00 \\
\hline $\mathrm{SO}_{3}^{(b)}$ & $0.80+0.15^{(1)}$ & - & 0.95 \\
\hline SUM & 30.46 & 69.54 & 100.00 \\
\hline
\end{tabular}

(a) Simulant was ordered at a concentration of $22.69 \mathrm{wt} \% \mathrm{Na}_{2} \mathrm{O}$ and modified before each melter test with (1) $\mathrm{Na}_{2} \mathrm{SO}_{4}$ and (2) $\mathrm{NaOH}$ additions to obtain $23 \mathrm{wt} \% \mathrm{Na}_{2} \mathrm{O}$ in the glass.

(b) Concentration of $\mathrm{SO}_{3}$ was increased in steps during the melter tests from $0.80 \mathrm{wt} \% \mathrm{SO}_{3}$ in the glass up to $1.2 \mathrm{wt} \%$.

- Empty data field 
Table 2.13. Glass Former Additives for 1 Liter of LAW Envelope A Simulant (8 M Na) and Corresponding Melter Feed Properties.

\begin{tabular}{|c|c|}
\hline Additives Source & Feed LAWA187 \\
\hline Additives in Glass (wt\%) & $69.54 \%$ \\
\hline Kyanite $\left(\mathrm{Al}_{2} \mathrm{SiO}_{5}\right) 325$ Mesh (Kyanite Mining) (g) & 103.54 \\
\hline $\mathrm{H}_{3} \mathrm{BO}_{3}$ (US Borax - Technical Granular) (g) & 248.05 \\
\hline Wollanstonite NYAD 325 Mesh (NYCO Minerals) (g) & 148.27 \\
\hline $\mathrm{Cr}_{2} \mathrm{O}_{3}$ oxide & 5.42 \\
\hline $\mathrm{Fe}_{2} \mathrm{O}_{3}$ (Prince Manufacturing) (g) & 7.08 \\
\hline Olivine $\left(\mathrm{Mg}_{2} \mathrm{SiO}_{4}\right) 325$ Mesh (\#180 Unimin) (g) & 20.54 \\
\hline $\mathrm{SiO}_{2}$ (Sil-co-Sil 75 US Silica) (g) & 232.23 \\
\hline SnO2 - Stannous Oxide - Mason color & 10.82 \\
\hline $\mathrm{V}_{2} \mathrm{O}_{5}$ (Pulva ground STRATCOR) g & 10.52 \\
\hline ZnO (KADOX - 920 Zinc Corp. of America) (g) & 32.40 \\
\hline Zircon $\mathrm{ZrSiO}_{4}$ (Flour) Mesh 325 (AM. Mineral) (g) & 48.52 \\
\hline Supplemental $\mathrm{Na}_{2} \mathrm{SO}_{4}$ & Variable \\
\hline Addition of Sucrose as Reductant (g) & 78.5 \\
\hline KI (spike) (g) & 1.39 \\
\hline Simulant Weight for 1 liter (g) & 1357 \\
\hline Sum of Additives (g) & 947 \\
\hline Sum of Complete Batch (g) & 2304 \\
\hline Target Final Volume (l) & 1.32 \\
\hline Target Density (g/ml) & 1.75 \\
\hline Target Glass Produced (g) & 1078 \\
\hline Target Weight \% Water in Slurry Feed & $43 \%$ \\
\hline Target Weight \% Additives in Slurry & $41 \%$ \\
\hline Target Glass Yield (g/kg of Feed) & 469 \\
\hline Target Glass Yield (g/l of Feed) & 820 \\
\hline Target Total Solids ( $\mathrm{g} / \mathrm{l}$ of Feed) & 998 \\
\hline Target Additives (g/l of Feed) & 720 \\
\hline
\end{tabular}

Table 2.14. $\mathrm{NaOH}$ and $\mathrm{Na}_{2} \mathrm{SO}_{4}$ Additions Required to Obtain $23 \mathrm{wt} \% \mathrm{Na}_{2} \mathrm{O}$ and Various $\mathrm{SO}_{3}$ Concentrations in the LAWA187 Glass Ranging from 0.80 to $1.2 \mathrm{wt} \%$.

\begin{tabular}{|c|c|c|}
\hline $\begin{array}{c}\text { Final } \\
\mathrm{SO}_{3} \mathrm{wt} \%\end{array}$ & $\begin{array}{c}\mathrm{NaOH} \text { needed } \\
\text { per kg of feed } \\
\text { (grams) }\end{array}$ & $\begin{array}{c}\mathrm{Na}_{2} \mathrm{SO}_{4} \text { needed } \\
\text { per kg of feed } \\
\text { (grams) }\end{array}$ \\
\hline 0.80 & 3.89 & 0.00 \\
\hline 0.90 & 2.92 & 0.87 \\
\hline 0.95 & 2.42 & 1.32 \\
\hline 1.00 & 1.94 & 1.75 \\
\hline 1.05 & 1.45 & 2.20 \\
\hline 1.10 & 0.97 & 2.62 \\
\hline 1.20 & 0.00 & 3.50 \\
\hline
\end{tabular}


Table 2.15. LAW Sub-Envelope B2 Simulant Recipe at 4 Molar Sodium.

\begin{tabular}{|c|c|c|c|c|c|c|c|c|c|}
\hline $\begin{array}{c}\text { Envelope } \\
\text { Constituents }\end{array}$ & \multicolumn{2}{|c|}{$\begin{array}{c}\text { Simulant AZ-102 } \\
\text { including pretreatment }\end{array}$} & \multirow{2}{*}{$\begin{array}{c}\text { Glass } \\
\text { Oxides } \\
\text { - }\end{array}$} & \multirow{2}{*}{$\begin{array}{c}\text { LAW B2 } \\
\text { Simulant as } \\
\text { Oxides (wt\%) } \\
\\
\end{array}$} & Source in Simulant & $\begin{array}{c}\text { Order } \\
\text { for } \\
\text { Addition }\end{array}$ & $\begin{array}{l}\text { Formula } \\
\text { Weight }\end{array}$ & \multirow[t]{2}{*}{ Assay* } & \multirow[t]{2}{*}{$\begin{array}{c}\text { Target } \\
\text { Weight (g) }\end{array}$} \\
\hline- & $\mathrm{mg} / \mathrm{L}$ & Molarity & & & \multicolumn{3}{|c|}{ In $913 \mathrm{ml}$ water add following compounds in the order listed. } & & \\
\hline $\mathrm{Al}$ & 246 & 0.009 & $\mathrm{Al}_{2} \mathrm{O}_{3}$ & 0.320 & $\mathrm{Al}\left(\mathrm{NO}_{3}\right) 3.9 \mathrm{H}_{2} \mathrm{O}, 60 \%$ sol. & 8 & 375.14 & 0.607 & 5.65 \\
\hline $\mathrm{B}$ & 51 & 0.009 & $\mathrm{~B}_{2} \mathrm{O}_{3}$ & 0.112 & $\mathrm{H}_{3} \mathrm{BO}_{3}$ & 4 & 61.83 & 0.99 & 0.29 \\
\hline $\mathrm{Cr}$ & 939 & 0.018 & $\mathrm{Cr}_{2} \mathrm{O}_{3}$ & 0.941 & $\mathrm{Na}_{2} \mathrm{CrO}_{4} * 4 \mathrm{H}_{2} \mathrm{O}$ & 2 & 234.04 & 0.985 & 4.29 \\
\hline $\mathrm{K}$ & 4248 & 0.109 & $\mathrm{~K}_{2} \mathrm{O}$ & 3.511 & $\mathrm{KOH}$ & 7 & 56.098 & 0.908 & 6.71 \\
\hline $\mathrm{Na}$ & 91960 & 4.000 & $\mathrm{Na}_{2} \mathrm{O}$ & 85.056 & $\mathrm{NaOH}, 50 \%$ sol. $\mathrm{d}=1.53$ & 6 & 40 & 0.501 & 35.42 \\
\hline $\mathrm{Si}$ & 343 & 0.012 & $\mathrm{SiO}_{2}$ & 0.503 & $\mathrm{SiO}_{2}$ & 5 & 60.09 & 0.99 & 0.74 \\
\hline $\mathrm{Cl}$ & 114 & 0.003 & $\mathrm{Cl}$ & 0.078 & $\mathrm{NaCl}$ & 10 & 58.45 & 0.99 & 0.19 \\
\hline $\mathrm{F}$ & 852 & 0.045 & $\mathrm{~F}$ & 0.584 & $\mathrm{NaF}$ & 11 & 42 & 0.99 & 1.90 \\
\hline $\mathrm{PO}_{4}$ & 494 & 0.005 & $\mathrm{P}_{2} \mathrm{O}_{5}$ & 0.253 & $\mathrm{Na}_{3} \mathrm{PO}_{4} \cdot 12 \mathrm{H}_{2} \mathrm{O}$ & 9 & 380.12 & 0.99 & 2.00 \\
\hline $\mathrm{SO}_{4}$ & 15111 & 0.157 & $\mathrm{SO}_{3}$ & 8.642 & $\mathrm{Na}_{2} \mathrm{SO}_{4}$ & 12 & 142.06 & 0.99 & 22.57 \\
\hline $\mathrm{NO}_{2}$ & 47361 & 1.030 & - & - & $\mathrm{NaNO}_{2}$ & 14 & 69 & 0.995 & 71.40 \\
\hline $\mathrm{NO}_{3}$ & 15673 & 0.253 & - & - & $\mathrm{NaNO}_{3}$ & 15 & 84.99 & 0.99 & 19.35 \\
\hline $\mathrm{CO}_{3}$ & 53553 & 0.892 & - & - & $\mathrm{Na}_{2} \mathrm{CO}_{3}$ & 1 & 105.99 & 1 & 94.59 \\
\hline Org.Carbon & 1215 & 0.101 & - & - & - & - & - & - & - \\
\hline Oxalate & 4484 & 0.051 & - & - & Sodium Oxalate (C2) & 13 & 134 & 0.99 & 6.90 \\
\hline - & - & - & SUM & 100.0 & \multicolumn{4}{|c|}{ Total simulant wt. } & 1185.42 \\
\hline
\end{tabular}

- Empty data field.

* - Assay refers to the purity of the raw material as specified by the vendor. 
Table 2.16. Target and Analyzed Compositions (wt\%) of Nine Envelope B Crucible Glasses.

\begin{tabular}{|c|c|c|c|c|c|c|c|c|c|c|}
\hline \multirow{2}{*}{ Oxides } & \multicolumn{2}{|c|}{ LAWB97 } & \multicolumn{2}{|c|}{ LAWB98 } & \multicolumn{2}{|c|}{ LAWB99 } & \multicolumn{2}{|c|}{ LAWB100 } & \multicolumn{2}{|c|}{ LAWB101 } \\
\hline & Target & Analyzed $^{*}$ & Target & Analyzed $^{*}$ & Target & Analyzed $^{*}$ & Target & Analyzed ${ }^{*}$ & Target & Analyzed* \\
\hline $\mathrm{Al}_{2} \mathrm{O}_{3}$ & 9.15 & 9.08 & 10.15 & 10.04 & 10.15 & 9.89 & 9.15 & 9.19 & 10.15 & 9.94 \\
\hline $\mathrm{B}_{2} \mathrm{O}_{3}$ & 10.01 & $10.27^{*}$ & 11.01 & $11.35^{*}$ & 11.01 & $11.31^{*}$ & 11.52 & $11.91^{*}$ & 10.01 & $10.33^{*}$ \\
\hline $\mathrm{CaO}$ & 9.20 & 8.85 & 9.20 & 8.77 & 10.21 & 9.95 & 10.71 & 9.52 & 11.21 & 10.69 \\
\hline $\mathrm{Cr}_{2} \mathrm{O}_{3}$ & 0.11 & 0.12 & 0.11 & 0.11 & 0.11 & 0.13 & 0.11 & 0.11 & 0.11 & 0.11 \\
\hline $\mathrm{Fe}_{2} \mathrm{O}_{3}$ & 1.15 & 1.19 & 1.15 & 1.17 & 1.15 & 1.23 & 1.15 & 1.05 & 1.15 & 1.18 \\
\hline $\mathrm{K}_{2} \mathrm{O}$ & 0.41 & 0.53 & 0.41 & 0.51 & 0.41 & 0.51 & 0.41 & 0.47 & 0.41 & 0.51 \\
\hline $\mathrm{Li}_{2} \mathrm{O}$ & 3.54 & $3.37^{*}$ & 3.54 & $3.38^{*}$ & 3.54 & $3.33^{*}$ & 3.54 & $3.39^{*}$ & 3.54 & $3.36^{*}$ \\
\hline $\mathrm{MgO}$ & 1.15 & 0.96 & 1.15 & 0.96 & 1.15 & 0.99 & 1.15 & 1.06 & 1.15 & 1.03 \\
\hline $\mathrm{Na}_{2} \mathrm{O}$ & 10.00 & 10.65 & 10.00 & 10.75 & 10.00 & 10.43 & 10.00 & 11.28 & 10.00 & 11.06 \\
\hline $\mathrm{SiO}_{2}$ & 46.08 & 47.08 & 44.08 & 45.61 & 43.08 & 44.36 & 43.07 & 45.53 & 43.08 & 44.22 \\
\hline $\mathrm{V}_{2} \mathrm{O}_{5}$ & 1.24 & 1.44 & 1.24 & 1.43 & 1.24 & 1.47 & 1.24 & 1.30 & 1.24 & 1.47 \\
\hline $\mathrm{ZnO}$ & 3.54 & 3.39 & 3.54 & 3.30 & 3.54 & 3.48 & 3.54 & 2.94 & 3.54 & 3.37 \\
\hline $\mathrm{ZrO}_{2}$ & 3.54 & 3.82 & 3.54 & 3.71 & 3.54 & 3.93 & 3.54 & 3.25 & 3.54 & 3.82 \\
\hline $\mathrm{Cl}$ & 0.01 & 0.00 & 0.01 & 0.00 & 0.01 & 0.00 & 0.01 & 0.01 & 0.01 & 0.00 \\
\hline$F$ & 0.07 & NA & 0.07 & NA & 0.07 & NA & 0.07 & NA & 0.07 & NA \\
\hline $\mathrm{P}_{2} \mathrm{O}_{5}$ & 0.03 & 0.04 & 0.03 & 0.04 & 0.03 & 0.04 & 0.03 & 0.04 & 0.03 & 0.04 \\
\hline $\mathrm{SO}_{3}$ & 0.75 & 0.63 & 0.75 & 0.58 & 0.75 & 0.64 & 0.75 & 0.69 & 0.75 & 0.57 \\
\hline SUM & 100.0 & 101.4 & 100.0 & 101.7 & 100.0 & 101.7 & 100.0 & 101.7 & 100.0 & 101.7 \\
\hline
\end{tabular}

* Analyzed by X-ray fluorescence except for boron and lithium which were measured by DCP

NA - Not analyzed 
Table 2.16. Target and Analyzed Compositions (wt\%) of Nine Envelope B Crucible Glasses (continued).

\begin{tabular}{|c|c|c|c|c|c|c|c|c|}
\hline \multirow{2}{*}{ Oxides } & \multicolumn{2}{|c|}{ LAWB102 } & \multicolumn{2}{|c|}{ LAWB103 } & \multicolumn{2}{|c|}{ LAWB104 } & \multicolumn{2}{|c|}{ LAWB105 } \\
\hline & Target & Analyzed ${ }^{*}$ & Target & Analyzed* & Target & Analyzed* & Target & Analyzed* \\
\hline $\mathrm{Al}_{2} \mathrm{O}_{3}$ & 9.15 & 9.00 & 9.15 & 9.07 & 10.15 & 10.11 & 6.15 & 6.43 \\
\hline $\mathrm{B}_{2} \mathrm{O}_{3}$ & 10.01 & $10.46^{*}$ & 10.01 & $10.41^{*}$ & 10.01 & $10.45^{*}$ & 13.02 & $12.89^{*}$ \\
\hline $\mathrm{CaO}$ & 12.21 & 11.65 & 9.20 & 8.89 & 11.21 & 10.89 & 9.20 & 8.57 \\
\hline $\mathrm{Cr}_{2} \mathrm{O}_{3}$ & 0.11 & 0.13 & 0.11 & 0.12 & 0.11 & 0.13 & 0.11 & 0.12 \\
\hline $\mathrm{Fe}_{2} \mathrm{O}_{3}$ & 1.15 & 1.18 & 1.15 & 1.18 & 1.15 & 1.24 & 1.15 & 1.17 \\
\hline $\mathrm{K}_{2} \mathrm{O}$ & 0.41 & 0.50 & 0.41 & 0.51 & 0.41 & 0.50 & 0.41 & 0.51 \\
\hline $\mathrm{Li}_{2} \mathrm{O}$ & 3.54 & $3.37^{*}$ & 4.04 & $3.86^{*}$ & 4.04 & $3.82^{*}$ & 3.54 & $3.33^{*}$ \\
\hline $\mathrm{MgO}$ & 1.15 & 0.96 & 1.15 & 1.02 & 1.15 & 1.01 & 1.15 & 1.06 \\
\hline $\mathrm{Na}_{2} \mathrm{O}$ & 10.00 & 10.86 & 10.00 & 11.03 & 10.00 & 10.68 & 10.00 & 10.68 \\
\hline $\mathrm{SiO}_{2}$ & 43.08 & 44.46 & 45.59 & 46.73 & 42.59 & 43.70 & 46.08 & 47.55 \\
\hline $\mathrm{V}_{2} \mathrm{O}_{5}$ & 1.24 & 1.47 & 1.24 & 1.46 & 1.24 & 1.49 & 1.24 & 1.38 \\
\hline $\mathrm{ZnO}$ & 3.54 & 3.37 & 3.54 & 3.39 & 3.54 & 3.50 & 3.54 & 3.24 \\
\hline $\mathrm{ZrO}_{2}$ & 3.54 & 3.76 & 3.54 & 3.79 & 3.54 & 3.45 & 3.54 & 3.34 \\
\hline $\mathrm{Cl}$ & 0.01 & 0.00 & 0.01 & 0.00 & 0.01 & 0.02 & 0.01 & 0.00 \\
\hline $\mathrm{F}$ & 0.07 & NA & 0.07 & NA & 0.07 & NA & 0.07 & NA \\
\hline $\mathrm{P}_{2} \mathrm{O}_{5}$ & 0.03 & 0.04 & 0.03 & 0.04 & 0.03 & 0.04 & 0.03 & 0.04 \\
\hline $\mathrm{SO}_{3}$ & 0.75 & 0.51 & 0.75 & 0.61 & 0.75 & 0.82 & 0.75 & 0.55 \\
\hline SUM & 100.0 & 101.7 & 100.0 & 102.1 & 100.0 & 101.8 & 100.0 & 100.9 \\
\hline
\end{tabular}

* Analyzed by X-ray fluorescence except for boron and lithium which were measured by DCP

NA - Not analyzed 
Table 2.17. Measured Compositions (wt\%) of Nine New LAW Envelope B Crucible Glasses Remelted with 4 wt\% Excess $\mathrm{SO}_{3}$.

\begin{tabular}{|c|c|c|c|c|c|c|c|c|c|c|}
\hline \multirow{2}{*}{ Oxides } & \multicolumn{2}{|c|}{ LAWB97S4 } & \multicolumn{2}{|c|}{ LAWB98S4 } & \multicolumn{2}{|c|}{ LAWB99S4 } & \multicolumn{2}{|c|}{ LAWB100S4 } & \multicolumn{2}{|c|}{ LAWB101S4 } \\
\hline & XRF & $\begin{array}{l}\text { XRF after } \\
\text { washing }\end{array}$ & XRF & $\begin{array}{c}\text { XRF after } \\
\text { washing }\end{array}$ & XRF & $\begin{array}{c}\text { XRF after } \\
\text { washing }\end{array}$ & XRF & $\begin{array}{c}\text { XRF after } \\
\text { washing }\end{array}$ & XRF & $\begin{array}{c}\text { XRF after } \\
\text { washing }\end{array}$ \\
\hline $\mathrm{Al}_{2} \mathrm{O}_{3}$ & 9.23 & 9.27 & 10.09 & 10.06 & 9.94 & 10.09 & 9.19 & 9.17 & 10.14 & 10.26 \\
\hline $\mathrm{B}_{2} \mathrm{O}_{3}$ & $\mathrm{NA}^{*}$ & $\mathrm{NA}^{*}$ & $\mathrm{NA}^{*}$ & $\mathrm{NA}^{*}$ & $\mathrm{NA}^{*}$ & $\mathrm{NA}^{*}$ & $\mathrm{NA}^{*}$ & $\mathrm{NA}^{*}$ & $\mathrm{NA}^{*}$ & $\mathrm{NA}^{*}$ \\
\hline $\mathrm{CaO}$ & 8.28 & 8.26 & 8.21 & 8.24 & 9.54 & 9.12 & 9.86 & 9.74 & 10.52 & 10.17 \\
\hline $\mathrm{Cr}_{2} \mathrm{O}_{3}$ & 0.11 & 0.11 & 0.09 & 0.10 & 0.12 & 0.11 & 0.11 & 0.11 & 0.11 & 0.10 \\
\hline $\mathrm{Fe}_{2} \mathrm{O}_{3}$ & 1.17 & 1.17 & 1.13 & 1.16 & 1.20 & 1.15 & 1.15 & 1.18 & 1.20 & 1.19 \\
\hline $\mathrm{K}_{2} \mathrm{O}$ & 0.44 & 0.43 & 0.41 & 0.42 & 0.43 & 0.42 & 0.43 & 0.42 & 0.42 & 0.41 \\
\hline $\mathrm{Li}_{2} \mathrm{O}$ & $\mathrm{NA}^{*}$ & $\mathrm{NA}^{*}$ & $\mathrm{NA}^{*}$ & $\mathrm{NA}^{*}$ & $\mathrm{NA}^{*}$ & $\mathrm{NA}^{*}$ & $\mathrm{NA}^{*}$ & $\mathrm{NA}^{*}$ & $\mathrm{NA}^{*}$ & $\mathrm{NA}^{*}$ \\
\hline $\mathrm{MgO}$ & 1.05 & 0.97 & 1.07 & 1.00 & 1.02 & 1.00 & 1.02 & 1.01 & 1.02 & 0.97 \\
\hline $\mathrm{Na}_{2} \mathrm{O}$ & 11.83 & 11.31 & 12.09 & 11.80 & 11.40 & 11.66 & 11.32 & 11.05 & 10.96 & 11.37 \\
\hline $\mathrm{SiO}_{2}$ & 46.64 & 47.02 & 45.14 & 45.16 & 43.84 & 44.30 & 44.28 & 44.31 & 44.23 & 44.30 \\
\hline $\mathrm{V}_{2} \mathrm{O}_{5}$ & 1.35 & 1.39 & 1.35 & 1.37 & 1.41 & 1.37 & 1.39 & 1.40 & 1.44 & 1.39 \\
\hline $\mathrm{ZnO}$ & 3.21 & 3.25 & 3.11 & 3.19 & 3.37 & 3.21 & 3.25 & 3.29 & 3.39 & 3.31 \\
\hline $\mathrm{ZrO}_{2}$ & 3.49 & 3.64 & 3.32 & 3.53 & 3.69 & 3.59 & 3.44 & 3.80 & 3.68 & 3.69 \\
\hline $\mathrm{Cl}$ & 0.01 & 0.01 & 0.00 & 0.00 & 0.01 & 0.00 & 0.00 & 0.01 & 0.01 & 0.00 \\
\hline $\mathrm{P}_{2} \mathrm{O}_{5}$ & 0.00 & 0.00 & 0.04 & 0.03 & 0.04 & & 0.03 & 0.04 & 0.04 & 0.04 \\
\hline $\mathrm{SO}_{3}$ & 1.08 & 1.05 & 1.04 & 1.00 & 1.11 & 1.08 & 1.04 & 1.02 & 0.90 & 0.88 \\
\hline SUM & 101.4 & 101.4 & 101.6 & 101.6 & 101.7 & 101.6 & 101.6 & 101.6 & 101.6 & 101.6 \\
\hline
\end{tabular}


Table 2.17. Measured Compositions of Nine New LAW Envelope B Crucible Glasses Remelted with 4 wt $\%$ Excess $\mathrm{SO}_{3}$ (continued).

\begin{tabular}{|c|c|c|c|c|c|c|c|c|}
\hline \multirow{2}{*}{ Oxides } & \multicolumn{2}{|c|}{ LAWB102S4 } & \multicolumn{2}{|c|}{ LAWB103S4 } & \multicolumn{2}{|c|}{ LAWB104S4 } & \multicolumn{2}{|c|}{ LAWB105S4 } \\
\hline & XRF & $\begin{array}{l}\text { XRF after } \\
\text { washing }\end{array}$ & XRF & $\begin{array}{l}\text { XRF after } \\
\text { washing }\end{array}$ & XRF & $\begin{array}{l}\text { XRF after } \\
\text { washing }\end{array}$ & $\mathrm{XRF}$ & $\begin{array}{c}\text { XRF after } \\
\text { washing }\end{array}$ \\
\hline $\mathrm{Al}_{2} \mathrm{O}_{3}$ & 9.02 & 9.26 & 9.03 & 9.11 & 9.98 & 10.01 & 6.18 & 6.19 \\
\hline $\mathrm{B}_{2} \mathrm{O}_{3}$ & $\mathrm{NA}^{*}$ & $\mathrm{NA}^{*}$ & $\mathrm{NA}^{*}$ & $\mathrm{NA}^{*}$ & $\mathrm{NA}^{*}$ & $\mathrm{NA}^{*}$ & $\mathrm{NA}^{*}$ & $\mathrm{NA}^{*}$ \\
\hline $\mathrm{CaO}$ & 11.40 & 10.92 & 8.32 & 8.30 & 10.29 & 10.26 & 8.23 & 8.30 \\
\hline $\mathrm{Cr}_{2} \mathrm{O}_{3}$ & 0.12 & 0.11 & 0.11 & 0.12 & 0.11 & 0.11 & 0.11 & 0.12 \\
\hline $\mathrm{Fe}_{2} \mathrm{O}_{3}$ & 1.20 & 1.15 & 1.14 & 1.16 & 1.14 & 1.19 & 1.14 & 1.17 \\
\hline $\mathrm{K}_{2} \mathrm{O}$ & 0.42 & 0.40 & 0.42 & 0.42 & 0.40 & 0.40 & 0.41 & 0.41 \\
\hline $\mathrm{Li}_{2} \mathrm{O}$ & $\mathrm{NA}^{*}$ & $\mathrm{NA}^{*}$ & $\mathrm{NA}^{*}$ & $\mathrm{NA}^{*}$ & $\mathrm{NA}^{*}$ & $\mathrm{NA}^{*}$ & $\mathrm{NA}^{*}$ & $\mathrm{NA}^{*}$ \\
\hline $\mathrm{MgO}$ & 1.02 & 1.04 & 0.99 & 0.97 & 1.04 & 1.02 & 1.05 & 0.98 \\
\hline $\mathrm{Na}_{2} \mathrm{O}$ & 11.26 & 11.50 & 12.12 & 11.75 & 11.48 & 11.34 & 12.05 & 10.99 \\
\hline $\mathrm{SiO}_{2}$ & 44.18 & 44.46 & 46.03 & 46.39 & 43.87 & 43.77 & 46.52 & 47.17 \\
\hline $\mathrm{V}_{2} \mathrm{O}_{5}$ & 1.43 & 1.39 & 1.37 & 1.41 & 1.37 & 1.41 & 1.36 & 1.39 \\
\hline $\mathrm{ZrO}_{2}$ & 3.59 & 3.61 & 3.60 & 3.46 & 3.63 & 3.80 & 3.45 & 3.73 \\
\hline $\mathrm{Cl}$ & 0.00 & 0.00 & 0.01 & 0.01 & 0.01 & 0.00 & 0.00 & 0.00 \\
\hline $\mathrm{P}_{2} \mathrm{O}_{5}$ & 0.04 & 0.04 & 0.04 & 0.04 & 0.03 & 0.04 & 0.04 & 0.04 \\
\hline $\mathrm{SO}_{3}$ & 0.93 & 0.87 & 1.08 & 1.07 & 0.99 & 0.96 & 0.98 & 0.96 \\
\hline SUM & 101.49 & 101.51 & 101.49 & 101.47 & 101.64 & 101.65 & 101.27 & 101.25 \\
\hline
\end{tabular}


Table 2.18. Results of 7-day PCT (at $90^{\circ} \mathrm{C}$ ) and VHT (at $200^{\circ} \mathrm{C}$ for 24 Days (g/m $\left./ \mathrm{m}^{2} / \mathrm{day}\right)$ ) for Nine New LAW Envelope B Crucible Glasses.

\begin{tabular}{|c|c|c|c|c|c|c|c|c|c|}
\hline & LAWB97 & LAWB98 & LAWB99 & LAWB100 & LAWB101 & LAWB102 & LAWB103 & LAWB104 & LAWB105 \\
\hline \multicolumn{10}{|c|}{ 7-Day PCT, Stainless Steel Vessel; S/V=2000m ${ }^{-1}$ (ppm) } \\
\hline $\mathrm{B}$ & 7.44 & 8.29 & 8.09 & 9.57 & 6.88 & 8.49 & 8.26 & 6.73 & 20.81 \\
\hline $\mathrm{Na}$ & 27.86 & 26.26 & 30.70 & 31.60 & 30.67 & 33.39 & 30.17 & 30.24 & 48.83 \\
\hline $\mathrm{Si}$ & 33.52 & 28.94 & 28.82 & 29.82 & 29.00 & 28.58 & 32.17 & 27.39 & 51.85 \\
\hline \multicolumn{10}{|c|}{7 Day PCT Normalized Concentrations, g/L } \\
\hline $\mathrm{B}$ & 0.24 & 0.24 & 0.24 & 0.27 & 0.22 & 0.27 & 0.27 & 0.22 & 0.52 \\
\hline $\mathrm{Na}$ & 0.38 & 0.35 & 0.41 & 0.43 & 0.41 & 0.45 & 0.41 & 0.41 & 0.66 \\
\hline $\mathrm{Si}$ & 0.16 & 0.14 & 0.14 & 0.15 & 0.14 & 0.14 & 0.15 & 0.14 & 0.24 \\
\hline $\mathrm{pH}$ & 10.58 & 10.53 & 10.65 & 10.64 & 10.74 & 10.68 & 10.61 & 10.75 & 10.46 \\
\hline \multicolumn{10}{|l|}{7 Day PCT g/m2 } \\
\hline $\mathrm{B}$ & 0.12 & 0.12 & 0.12 & 0.13 & 0.11 & 0.14 & 0.13 & 0.11 & 0.26 \\
\hline $\mathrm{Na}$ & 0.19 & 0.18 & 0.21 & 0.21 & 0.21 & 0.23 & 0.20 & 0.20 & 0.33 \\
\hline $\mathrm{Si}$ & 0.08 & 0.07 & 0.07 & 0.07 & 0.07 & 0.07 & 0.08 & 0.07 & 0.12 \\
\hline \multicolumn{10}{|c|}{7 Day PCT Normalized Leached Rate, g/d/m² } \\
\hline $\mathrm{B}$ & 0.02 & 0.02 & 0.02 & 0.02 & 0.02 & 0.02 & 0.02 & 0.02 & 0.04 \\
\hline $\mathrm{Na}$ & 0.03 & 0.03 & 0.03 & 0.03 & 0.03 & 0.03 & 0.03 & 0.03 & 0.05 \\
\hline $\mathrm{Si}$ & 0.01 & 0.01 & 0.01 & 0.01 & 0.01 & 0.01 & 0.01 & 0.01 & 0.02 \\
\hline \multicolumn{10}{|c|}{ VHT Alteration $\left(24\right.$ days at $200^{\circ} \mathrm{C}$ ) } \\
\hline Alteration depth $(\mu \mathrm{m})$ & 172 & 145 & 135 & 118 & 121 & 156 & 62 & 273 & 30 \\
\hline $\begin{array}{l}\text { Alteration Rate } \\
\text { (g/m²/day) calculated } \\
\text { using measured density }\end{array}$ & 19 & 16 & 15 & 13 & 13 & 17 & 7 & 30 & 3 \\
\hline
\end{tabular}


Table 2.19. Viscosities and Electrical Conductivities of Nine New LAW Envelope B Crucible Glasses.

\begin{tabular}{|c|c|c|c|c|c|c|c|c|c|}
\hline Glass ID & LAWB97 & LAWB98 & LAWB99 & LAWB100 & LAWB101 & LAWB102 & LAWB103 & LAWB104 & LAWB105 \\
\hline \multicolumn{10}{|c|}{ Viscosity (poise) } \\
\hline 900 & 1074 & 817 & 739 & 552 & 777 & 683 & 788 & 573 & 576 \\
\hline 950 & 473 & 368 & 339 & 254 & 348 & 279 & 368 & 259 & 263 \\
\hline 1000 & 234 & 186 & 172 & 129 & 175 & 136 & 189 & 131 & 135 \\
\hline 1050 & 128 & 102 & 95 & 72 & 96 & 76 & 105 & 73 & 75 \\
\hline 1100 & 75 & 60 & 56 & 43 & 57 & 46 & 62 & 43 & 45 \\
\hline 1150 & 47 & 38 & 35 & 27 & 36 & 31 & 39 & 28 & 29 \\
\hline 1200 & 31 & 25 & 23 & 18 & 24 & 21 & 26 & 18 & 19 \\
\hline 1250 & 21 & 17 & 16 & 12 & 17 & 16 & 18 & 13 & 14 \\
\hline \multicolumn{10}{|c|}{ Electrical Conductivity (S/cm) } \\
\hline 900 & 0.069 & 0.078 & 0.074 & 0.073 & 0.068 & 0.076 & 0.085 & 0.075 & 0.067 \\
\hline 950 & 0.099 & 0.107 & 0.105 & 0.106 & 0.093 & 0.106 & 0.116 & 0.109 & 0.096 \\
\hline 1000 & 0.135 & 0.141 & 0.144 & 0.147 & 0.125 & 0.143 & 0.155 & 0.150 & 0.131 \\
\hline 1050 & 0.177 & 0.183 & 0.192 & 0.193 & 0.163 & 0.189 & 0.202 & 0.197 & 0.173 \\
\hline 1100 & 0.224 & 0.231 & 0.252 & 0.244 & 0.209 & 0.243 & 0.256 & 0.250 & 0.222 \\
\hline 1150 & 0.277 & 0.286 & 0.324 & 0.300 & 0.264 & 0.308 & 0.319 & 0.309 & 0.277 \\
\hline 1200 & 0.335 & 0.349 & 0.409 & 0.360 & 0.328 & 0.384 & 0.390 & 0.373 & 0.337 \\
\hline 1250 & 0.397 & 0.418 & 0.510 & 0.424 & 0.401 & 0.471 & 0.470 & 0.441 & 0.404 \\
\hline
\end{tabular}


Table 2.20. Measured Densities and Glass Transition Temperatures (by Differential Thermal Analysis) of LAW Envelope B Crucible Glasses.

\begin{tabular}{|c|c|c|}
\hline $\begin{array}{l}\text { Glass } \\
\text { Name }\end{array}$ & $\begin{array}{c}\text { Density } \\
20^{\circ} \mathrm{C}(\mathrm{g} / \mathrm{cc})\end{array}$ & $\mathbf{T}_{\mathrm{G}}\left({ }^{\circ} \mathrm{C}\right)$ \\
\hline LAWB97 & 2.650 & - \\
\hline LAWB98 & 2.646 & - \\
\hline LAWB99 & 2.658 & 583 \\
\hline LAWB100 & 2.663 & - \\
\hline LAWB101 & 2.666 & - \\
\hline LAWB102 & 2.680 & - \\
\hline LAWB103 & 2.651 & - \\
\hline LAWB104 & 2.681 & - \\
\hline LAWB105 & 2.652 & - \\
\hline
\end{tabular}

- Empty data field

Table 2.21. Results of K-3 Corrosion Testing for Three of the New LAW Envelope B Crucible Glasses.

\begin{tabular}{|c|c|c|c|}
\hline Glass ID & $\begin{array}{c}\text { Neck loss } \\
\text { (inches) }\end{array}$ & $\begin{array}{c}\text { Depth of altered } \\
\text { zone (inches) }\end{array}$ & $\begin{array}{c}\text { Half-down loss } \\
\text { (inches) }\end{array}$ \\
\hline LAWB97 & 0.009 & 0.024 & 0.002 \\
\hline LAWB99 & 0.010 & 0.025 & 0.002 \\
\hline LAWB103 & 0.015 & 0.025 & 0.007 \\
\hline
\end{tabular}




\section{Table 2.22. Summary of Test Results for Selected Glass Formulation LAWB99 and Comparison to ILAW Requirements.}

\begin{tabular}{|l|c|c|}
\hline Test & Requirement $*$ & $\begin{array}{c}\text { Test Result for } \\
\text { LAWB99 }\end{array}$ \\
\hline Density of glass & $<3.7 \mathrm{~g} / \mathrm{cc}$ & $2.658 \mathrm{~g} / \mathrm{cc}$ \\
\hline Crystalline Phase & Phase Identification & $\begin{array}{c}\text { Clear homogeneous glass } \\
\text { down to } 850^{\circ} \mathrm{C}\end{array}$ \\
\hline Liquidus & $<950^{\circ} \mathrm{C}$ & $<850^{\circ} \mathrm{C}$ \\
\hline Centerline Canister Cooling & Phase Identification & Clear homogeneous glass \\
\hline PCT B $\left(\mathrm{g} / \mathrm{m}^{2}\right)$ & $<2.0 \mathrm{~g} / \mathrm{m}^{2}$ & $0.12 \mathrm{~g} / \mathrm{m}^{2}$ \\
\hline PCT Na $\left(\mathrm{g} / \mathrm{m}^{2}\right)$ & $<2.0 \mathrm{~g} / \mathrm{m}^{2}$ & $0.21 \mathrm{~g} / \mathrm{m}^{2}$ \\
\hline PCT Si $\left(\mathrm{g} / \mathrm{m}^{2}\right)$ & $<2.0 \mathrm{~g} / \mathrm{m}^{2}$ & $0.07 \mathrm{~g} / \mathrm{m}^{2}$ \\
\hline VHT at $200^{\circ} \mathrm{C}\left(\mathrm{g} / \mathrm{m}^{2} / \mathrm{day}\right)$ & $<50 \mathrm{~g} / \mathrm{m}^{2} / \mathrm{day}$ & $15 \mathrm{~g} / \mathrm{m}^{2} / \mathrm{day}$ \\
\hline Viscosity $($ poise $)$ at $1100^{\circ} \mathrm{C}$ & 10 to $150 \mathrm{P}$ & $56 \mathrm{P}$ \\
\hline Conductivity $(\mathrm{S} / \mathrm{cm})$ at $1100^{\circ} \mathrm{C}$ & 0.2 to $0.7 \mathrm{~S} / \mathrm{cm}$ & $0.25 \mathrm{~S} / \mathrm{cm}^{2}$ \\
\hline T $\left.{ }_{\mathrm{G}}{ }^{\circ} \mathrm{C}\right)$ & Report for modeling & $583^{\circ} \mathrm{C}$ \\
\hline
\end{tabular}

* - "Design, Construction, and Commissioning of the Hanford Tank Waste Treatment and Immobilization Plant", Contract Number: DE-AC27-01RV14136, Modification A029, U. S. Department of Energy, Office of River Protection, Richland WA, 2001, as amended. 


\section{Table 2.23. Oxide Composition of LAW Envelope B Simulant and Corresponding Glass Composition Used in Melter Tests (wt\%).}

\begin{tabular}{|c|c|c|c|}
\hline Component & $\begin{array}{l}\text { AZ-102 waste } \\
\text { contribution }\end{array}$ & $\begin{array}{l}\text { Glass former } \\
\text { additives }\end{array}$ & $\begin{array}{c}\text { LAWB99 } \\
\text { (for AZ-102) }\end{array}$ \\
\hline Loading & $11.93 \%$ & $88.07 \%$ & - \\
\hline $\mathrm{Al}_{2} \mathrm{O}_{3}$ & 0.037 & 10.06 & 10.10 \\
\hline $\mathrm{B}_{2} \mathrm{O}_{3}$ & 0.013 & 10.94 & 10.95 \\
\hline $\mathrm{CaO}$ & - & 10.15 & 10.15 \\
\hline $\mathrm{Cr}_{2} \mathrm{O}_{3}$ & 0.109 & - & 0.11 \\
\hline $\mathrm{Fe}_{2} \mathrm{O}_{3}$ & - & 1.14 & 1.14 \\
\hline $\mathrm{K}_{2} \mathrm{O}$ & 0.406 & - & 0.41 \\
\hline $\mathrm{Li}_{2} \mathrm{O}$ & - & 3.53 & 3.53 \\
\hline $\mathrm{MgO}$ & - & 1.14 & 1.14 \\
\hline $\mathrm{Na}_{2} \mathrm{O}^{(\mathrm{a})}$ & $9.845+0.155^{(1)}+0.00^{(2)}$ & - & 10.00 \\
\hline $\mathrm{SiO}_{2}$ & 0.058 & 42.84 & 42.90 \\
\hline $\mathrm{V}_{2} \mathrm{O}_{5}$ & - & 1.23 & 1.23 \\
\hline $\mathrm{ZnO}$ & - & 3.52 & 3.52 \\
\hline $\mathrm{ZrO}_{2}$ & - & 3.52 & 3.52 \\
\hline $\mathrm{Cl}$ & 0.009 & - & 0.01 \\
\hline F & 0.068 & - & 0.07 \\
\hline $\mathrm{P}_{2} \mathrm{O}_{5}$ & 0.029 & - & 0.03 \\
\hline $\mathrm{SO}_{3}{ }^{(b)}$ & $1.000+0.200^{(1)}$ & - & 1.20 \\
\hline SUM & 11.93 & 88.07 & 100.00 \\
\hline
\end{tabular}

(a) Simulant was ordered at a concentration of $9.84 \mathrm{wt} \% \mathrm{Na}_{2} \mathrm{O}$ and modified before each melter test with (1) $\mathrm{Na}_{2} \mathrm{SO}_{4}$ and (2) $\mathrm{NaOH}$ additions to obtain $10 \mathrm{wt} \% \mathrm{Na}_{2} \mathrm{O}$ in the glass.

(b) Concentration of $\mathrm{SO}_{3}$ was increased in steps during the melter tests from $1.00 \mathrm{wt} \% \mathrm{SO}_{3}$ in the glass up to $1.7 \mathrm{wt} \%$.

- Empty data field 
Table2.24. Glass Former Additives for 1 Liter of LAW Envelope B Simulant (4 M Na) and Corresponding Melter Feed Properties.

\begin{tabular}{|c|c|}
\hline Additives Source & Feed LAWB99 \\
\hline Additives in Glass (wt\%) & $88.07 \%$ \\
\hline Kyanite $\left(\mathrm{Al}_{2} \mathrm{SiO}_{5}\right) 325$ Mesh (Kyanite Mining) (g) & 213.90 \\
\hline $\mathrm{H}_{3} \mathrm{BO}_{3}$ (US Borax - Technical Granular) (g) & 240.81 \\
\hline Wollanstonite NYAD 325 Mesh (NYCO Minerals) (g) & 276.83 \\
\hline $\mathrm{Fe}_{2} \mathrm{O}_{3}$ (Prince Manufacturing) (g) & 10.86 \\
\hline $\mathrm{Li}_{2} \mathrm{CO}_{3}$ (Chemetall Foote Co. Technical grade) & 109.19 \\
\hline Olivine $\left(\mathrm{Mg}_{2} \mathrm{SiO}_{4}\right) 325 \mathrm{Mesh}(\# 180$ Unimin) $(\mathrm{g})$ & 24.96 \\
\hline $\mathrm{SiO}_{2}$ (Sil-co-Sil 75 US Silica) (g) & 262.95 \\
\hline $\mathrm{V}_{2} \mathrm{O}_{5}$ (Pulva ground STRATCOR) $\mathrm{g}$ & 15.18 \\
\hline ZnO (KADOX - 920 Zinc Corp. of America) (g) & 43.64 \\
\hline Zircon $\mathrm{ZrSiO}_{4}$ (Flour) Mesh 325 (AM. Mineral) (g) & 65.81 \\
\hline Supplemental $\mathrm{Na}_{2} \mathrm{SO}_{4}$ & Variable \\
\hline Addition of Sucrose as Reductant (g) & 24.52 \\
\hline KI (spike) (g) & 1.60 \\
\hline Simulant Weight for 1 liter (g) & 1185 \\
\hline Sum of Additives (g) & 1290 \\
\hline Sum of Complete Batch (g) & 2482 \\
\hline Target Final Volume (l) & 1.51 \\
\hline Target Density (g/ml) & 1.64 \\
\hline Target Glass Produced (g) & 1240 \\
\hline Target Weight \% Water in Slurry Feed & $44 \%$ \\
\hline Target Weight \% Additives in Slurry & $52 \%$ \\
\hline Target Glass Yield (g/kg of Feed) & 499 \\
\hline Target Glass Yield (g/l of Feed) & 819 \\
\hline Target Total Solids (g/l of Feed) & 922 \\
\hline Target Additives (g/l of Feed) & 853 \\
\hline
\end{tabular}

Table 2.25. $\mathrm{NaOH}$ and $\mathrm{Na}_{2} \mathrm{SO}_{4}$ Additions Required to Obtain $10 \mathrm{wt} \% \mathrm{Na}_{2} \mathrm{O}$ and Various $\mathrm{SO}_{3}$ Concentrations in the LAWB99 Glass Ranging from 1.0 to $1.6 \mathrm{wt} \%$.

\begin{tabular}{|c|c|c|}
\hline $\begin{array}{c}\text { Final } \\
\mathrm{SO}_{3} \mathrm{wt} \%\end{array}$ & $\begin{array}{c}\text { NaOH needed } \\
\text { per kg of feed } \\
\text { (grams) }\end{array}$ & $\begin{array}{c}\mathrm{Na}_{2} \mathrm{SO}_{4} \text { needed } \\
\text { per kg of feed } \\
\text { (grams) }\end{array}$ \\
\hline 1 & 2.00 & 0 \\
\hline 1.1 & 1.00 & 0.91 \\
\hline 1.2 & 0 & 1.82 \\
\hline 1.3 & 0 & 2.73 \\
\hline 1.4 & 0 & 3.64 \\
\hline 1.5 & 0 & 4.55 \\
\hline $1.6 *$ & 0 & 5.46 \\
\hline
\end{tabular}


Table 2.26. Properties of Feed Samples from DM10 and DM100 Melter Tests.

\begin{tabular}{|c|c|c|c|c|c|c|c|c|}
\hline \multirow{2}{*}{$\begin{array}{l}\text { Waste } \\
\text { Type }\end{array}$} & \multirow{2}{*}{ Test } & \multirow{2}{*}{ Date } & \multirow{2}{*}{ Sample Name } & \multirow{2}{*}{$\begin{array}{c}\% \\
\text { Water } \\
\end{array}$} & \multirow{2}{*}{$\begin{array}{c}\text { Density } \\
(\mathrm{g} / \mathrm{ml})\end{array}$} & \multicolumn{2}{|c|}{ Yield } & \multirow{2}{*}{$\mathbf{p H}$} \\
\hline & & & & & & (kg/kg) & $(g / l)$ & \\
\hline \multirow{8}{*}{$\begin{array}{c}\text { LAW } \\
\text { Sub- } \\
\text { Envelope } \\
\text { B2 }\end{array}$} & \multirow{2}{*}{ B3 } & $9 / 19 / 05$ & DWV-F-58A & 44.09 & 1.61 & 0.482 & 775 & 8.86 \\
\hline & & $9 / 21 / 05$ & DWV-F-103A & 43.57 & 1.63 & 0.488 & 795 & 8.87 \\
\hline & \multirow{2}{*}{ B4 } & $9 / 22 / 05$ & DWV-F-126A & 44.16 & 1.62 & 0.481 & 779 & 8.94 \\
\hline & & $9 / 25 / 05$ & EWV-F-10A & 44.53 & 1.62 & 0.491 & 795 & 8.91 \\
\hline & \multicolumn{3}{|c|}{ Average } & 44.09 & 1.62 & 0.485 & 786 & 8.90 \\
\hline & \multicolumn{3}{|c|}{ Target } & 44 & 1.64 & 0.499 & 819 & NA \\
\hline & \multicolumn{3}{|c|}{ LAWB96 + 15\% Simulant [13] } & 47.07 & 1.58 & 0.463 & 729 & 8.75 \\
\hline & \multicolumn{3}{|c|}{ LAWB96 - 15\% Simulant [13] } & 38.76 & 1.69 & 0.527 & 891 & 8.70 \\
\hline \multirow{10}{*}{$\begin{array}{c}\text { LAW } \\
\text { Sub- } \\
\text { Envelope } \\
\text { A1 }\end{array}$} & \multirow{3}{*}{ A3 } & $10 / 05 / 05$ & EWV-F-18A & 41.50 & 1.64 & 0.429 & 703 & 11.78 \\
\hline & & $10 / 08 / 05$ & EWV-F-76A & 42.06 & 1.63 & 0.446 & 727 & 11.87 \\
\hline & & $10 / 08 / 05$ & EWV-F-89A & 43.03 & 1.63 & 0.448 & 729 & 11.83 \\
\hline & \multirow{2}{*}{ A4 } & $10 / 08 / 05$ & EWV-F-94A & 42.38 & 1.66 & 0.437 & 726 & 11.81 \\
\hline & & $10 / 10 / 05$ & EWV-F-129A & 42.88 & 1.64 & 0.450 & 737 & 11.87 \\
\hline & \multicolumn{3}{|c|}{ Average } & 42.37 & 1.64 & 0.442 & 725 & 11.83 \\
\hline & \multicolumn{3}{|c|}{ Target } & 43 & 1.75 & 0.469 & 820 & NA \\
\hline & \multicolumn{3}{|c|}{ Average ( LAWA161) [2] } & 38.70 & 1.68 & 0.472 & 791 & 11.50 \\
\hline & \multicolumn{3}{|c|}{ High Temperature Test Average [3] } & 38.40 & 1.69 & 0.467 & 788 & 11.96 \\
\hline & \multicolumn{3}{|c|}{ DM1200 Average [49] } & 37.60 & 1.72 & 0.481 & 827 & 12.19 \\
\hline
\end{tabular}

NA -Not Applicable 
Table 2.27. Rheological Properties for Select Melter Feed Samples.

\begin{tabular}{|c|c|c|c|c|c|c|}
\hline \multirow{2}{*}{ Waste Type } & \multirow{2}{*}{ Test } & \multirow{2}{*}{ Sample Name } & Yield Stress & \multicolumn{3}{c|}{ Viscosity (Poise) } \\
\cline { 4 - 7 } & & $(\mathrm{Pa})$ & @1/s & @10/s & $@ 100 / \mathrm{s}$ \\
\hline \multirow{2}{*}{ LAW B } & Current Test & DWV-F-126A & 3.2 & 2.49 & 0.37 & 0.17 \\
\hline \multirow{2}{*}{ LAWA } & Current Test & EWV-F-76A & 0.2 & 1.68 & 0.35 & 0.24 \\
\cline { 2 - 7 } & \multicolumn{2}{|c|}{ LAWA161 [2] } & 0.2 & 1.24 & 0.42 & 0.36 \\
\hline \multirow{2}{*}{ LAWC } & \multicolumn{2}{|c|}{ LAWC [32] } & 0.9 & 0.53 & 0.93 & 0.47 \\
\hline
\end{tabular}


Table 2.28. XRF Analyzed Compositions for LAWB Melter Feed Samples (wt\%).

\begin{tabular}{|c|c|c|c|c|c|c|c|c|c|}
\hline \multirow[t]{2}{*}{ Test } & \multicolumn{4}{|c|}{ B3 } & \multicolumn{4}{|c|}{ B4 } & \multirow{2}{*}{$\begin{array}{l}\text { Average } \\
\% \text { Dev. }\end{array}$} \\
\hline & Target & $\begin{array}{c}\text { DWV-F- } \\
58 \mathrm{~A}\end{array}$ & $\begin{array}{c}\text { DWV-F- } \\
103 A\end{array}$ & Avg. & Target & $\begin{array}{c}\text { DWV-F- } \\
126 \mathrm{~A}\end{array}$ & \begin{tabular}{|c} 
EWV-F- \\
$10 \mathrm{~A}$
\end{tabular} & Avg. & \\
\hline $\mathrm{Al}_{2} \mathrm{O}_{3}$ & 10.06 & \begin{tabular}{|r|}
9.50 \\
\end{tabular} & 9.57 & 9.53 & 10.05 & 9.54 & \begin{tabular}{|l|}
10.56 \\
\end{tabular} & 10.05 & -2.62 \\
\hline $\mathrm{B}_{2} \mathrm{O}_{3} *$ & 10.91 & 10.91 & 10.91 & 10.91 & 10.89 & 10.89 & 10.89 & 10.89 & NC \\
\hline $\mathrm{CaO}$ & 10.11 & 10.02 & 9.85 & 9.94 & 10.10 & 9.89 & 9.33 & 9.61 & -3.25 \\
\hline $\mathrm{Cl}$ & 0.01 & $<0.01$ & $<0.01$ & $<0.01$ & 0.01 & $<0.01$ & $<0.01$ & $<0.01$ & $\mathrm{NC}$ \\
\hline $\mathrm{Cr}_{2} \mathrm{O}_{3}$ & 0.11 & 0.21 & 0.20 & 0.20 & 0.11 & 0.20 & 0.20 & 0.20 & $\mathrm{NC}$ \\
\hline $\mathrm{F}$ & 0.07 & NA & $\mathrm{NA}$ & $\mathrm{NC}$ & 0.07 & NA & NA & $\mathrm{NC}$ & $\mathrm{NC}$ \\
\hline $\mathrm{Fe}_{2} \mathrm{O}_{3}$ & 1.14 & 1.35 & 1.23 & 1.29 & 1.13 & 1.20 & 1.18 & 1.19 & 9.39 \\
\hline I & 0.10 & $<0.01$ & $<0.01$ & $<0.01$ & 0.10 & $<0.01$ & $<0.01$ & $<0.01$ & $\mathrm{NC}$ \\
\hline $\mathrm{K}_{2} \mathrm{O}$ & 0.40 & 0.60 & 0.56 & 0.58 & 0.40 & 0.57 & 0.55 & 0.56 & $\mathrm{NC}$ \\
\hline $\mathrm{Li}_{2} \mathrm{O}^{*}$ & 3.52 & 3.52 & 3.52 & 3.52 & 3.51 & 3.51 & 3.51 & 3.51 & NC \\
\hline $\mathrm{MgO}$ & 1.14 & 1.00 & 1.06 & 1.03 & 1.13 & 0.93 & 1.00 & 0.97 & -11.89 \\
\hline $\mathrm{Na}_{2} \mathrm{O}$ & 9.96 & 10.13 & 10.44 & 10.29 & 9.95 & 10.70 & 10.85 & 10.77 & 5.80 \\
\hline $\mathrm{P}_{2} \mathrm{O}_{5}$ & 0.03 & 0.07 & 0.08 & 0.07 & 0.03 & 0.07 & 0.08 & 0.07 & $\mathrm{NC}$ \\
\hline $\mathrm{SiO}_{2}$ & 42.73 & 43.71 & 43.89 & 43.80 & 42.68 & 43.79 & 43.82 & 43.81 & 2.58 \\
\hline $\mathrm{SO}_{3}$ & 1.50 & 0.54 & 0.45 & 0.50 & 1.60 & 0.53 & 0.60 & 0.56 & $\mathrm{NC}$ \\
\hline $\mathrm{TiO}_{2}$ & $\S$ & 0.23 & 0.22 & 0.23 & $\S$ & 0.22 & 0.23 & 0.22 & NC \\
\hline $\mathrm{V}_{2} \mathrm{O}_{5}$ & 1.23 & 1.50 & 1.44 & 1.47 & 1.22 & 1.46 & 1.31 & 1.38 & 16.44 \\
\hline $\mathrm{ZnO}$ & 3.51 & 3.05 & 2.88 & 2.96 & 3.50 & 2.82 & 2.55 & 2.69 & -19.35 \\
\hline $\mathrm{ZrO}_{2}$ & 3.51 & 3.66 & 3.70 & 3.68 & 3.50 & 3.66 & 3.34 & 3.50 & 2.49 \\
\hline Sum & 100.00 & 100.00 & 100.00 & 100.00 & 100.00 & 100.00 & 100.00 & 100.00 & $\mathrm{NC}$ \\
\hline
\end{tabular}

* - Target value; $§-$ Not a target constituent; NA - Not analyzed; NC - Not calculated 
Table 2.29. XRF Analyzed Compositions for LAWA Melter Feed Samples (wt \%).

\begin{tabular}{|c|c|c|c|c|c|c|c|c|c|c|}
\hline \multirow[t]{2}{*}{ Test } & \multicolumn{5}{|c|}{ A3 } & \multicolumn{4}{|c|}{ A4 } & \multirow{2}{*}{$\begin{array}{c}\text { Average } \\
\% \text { Dev. }\end{array}$} \\
\hline & Target & $\begin{array}{c}\text { EWV-F- } \\
18 \mathrm{~A}\end{array}$ & \begin{tabular}{|c|} 
EWV-F- \\
$76 \mathrm{~A}$
\end{tabular} & \begin{tabular}{|c|} 
EWV-F- \\
$89 \mathrm{~A}$
\end{tabular} & Avg. & Target & \begin{tabular}{|c|} 
EWV-F- \\
$94 \mathrm{~A}$
\end{tabular} & $\begin{array}{c}\text { EWV-F- } \\
129 \mathrm{~A} \\
\end{array}$ & Avg. & \\
\hline $\mathrm{Al}_{2} \mathrm{O}_{3}$ & 10.62 & 10.67 & \begin{tabular}{|r|}
10.71 \\
\end{tabular} & \begin{tabular}{|l|}
10.72 \\
\end{tabular} & 10.70 & 10.61 & 10.54 & 10.40 & 10.47 & -0.23 \\
\hline $\mathrm{B}_{2} \mathrm{O}_{3}{ }^{*}$ & 12.75 & 12.75 & 12.75 & 12.75 & 12.75 & 12.74 & 12.74 & 12.74 & 12.74 & $\mathrm{NC}$ \\
\hline $\mathrm{CaO}$ & 6.47 & 5.85 & 5.72 & 5.93 & 5.83 & 6.46 & 6.02 & 5.77 & 5.90 & -9.24 \\
\hline $\mathrm{Cl}$ & 0.65 & 0.21 & 0.05 & 0.07 & 0.11 & 0.65 & 0.07 & 0.33 & 0.20 & $\mathrm{NC}$ \\
\hline $\mathrm{Cr}_{2} \mathrm{O}_{3}$ & 52 & 0.58 & 0.59 & 0.60 & 0.59 & 0.52 & 0.59 & 0.65 & 0.62 & $\mathrm{NC}$ \\
\hline $\mathrm{F}$ & $<0.01$ & NA & NA & NA & $\mathrm{NC}$ & $<0.01$ & NA & NA & $\mathrm{NC}$ & $\mathrm{NC}$ \\
\hline $\mathrm{Fe}_{2} \mathrm{O}_{3}$ & 0.90 & 0.63 & 0.91 & 0.93 & 0.82 & 0.90 & 0.96 & 0.83 & 0.89 & $\mathrm{NC}$ \\
\hline I & 0.10 & 0.03 & 0.03 & 0.03 & 0.03 & 0.10 & 0.03 & \begin{tabular}{|l|}
0.07 \\
\end{tabular} & 0.05 & NC \\
\hline $\mathrm{K}_{2} \mathrm{O}$ & 51 & 0.56 & 0.57 & 0.53 & 0.55 & 0.51 & 0.52 & 0.57 & 0.55 & NC \\
\hline $\mathrm{MgO}$ & 90 & 0.47 & 0.68 & 0.77 & 0.64 & 0.90 & 1.04 & 0.93 & 0.98 & $\mathrm{NC}$ \\
\hline $\mathrm{Na}_{2} \mathrm{O}$ & 22.93 & 23.94 & 22.10 & 21.66 & 22.57 & 22.91 & 21.43 & 23.15 & 22.29 & -2.14 \\
\hline $\mathrm{P}_{2} \mathrm{O}_{5}$ & $\S$ & 0.02 & 0.02 & 0.02 & 0.02 & $\S$ & 0.03 & 0.02 & 0.02 & $\mathrm{NC}$ \\
\hline $\mathrm{SiO}_{2}$ & 34.75 & 36.44 & 37.19 & 36.68 & 36.77 & 34.72 & 36.50 & 35.49 & 36.00 & 4.74 \\
\hline $\mathrm{SnO}_{2}$ & 1.00 & 0.92 & 1.25 & 1.23 & 1.14 & 1.00 & 1.24 & 1.17 & 1.21 & 17.26 \\
\hline $\mathrm{SO}_{3}$ & 0.95 & 0.93 & 0.76 & 0.81 & 0.83 & 1.05 & 0.82 & 1.04 & 0.93 & $\mathrm{NC}$ \\
\hline $\mathrm{TiO}_{2}$ & $\S$ & 0.10 & 0.11 & 0.13 & 0.11 & $\S$ & 0.12 & 0.11 & 0.12 & $\mathrm{NC}$ \\
\hline $\mathrm{V}_{2} \mathrm{O}_{5}$ & 0.97 & 0.95 & 0.84 & 0.85 & 0.88 & 0.97 & 1.09 & 1.16 & 1.12 & $\mathrm{NC}$ \\
\hline $\mathrm{ZnO}$ & 2.99 & 2.72 & 2.83 & 3.02 & 2.86 & 2.98 & 2.97 & 2.76 & 2.87 & -4.11 \\
\hline $\mathrm{ZrO}_{2}$ & 2.99 & 2.22 & $\begin{array}{l}2.89 \\
\end{array}$ & 3.26 & 2.79 & 2.98 & 3.29 & 2.79 & 3.04 & 2.38 \\
\hline Sum & 100.00 & 100.00 & 100.00 & 100.00 & 100.00 & 100.00 & 100.00 & 100.00 & 100.00 & $\mathrm{NC}$ \\
\hline
\end{tabular}

* - Target value; $\S$ - Not a target constituent; NA - Not analyzed; NC - Not calculated 
Table 2.30. XRF and DCP Analyzed Compositions for Melter Feed Samples (wt\%).

\begin{tabular}{|c|c|c|c|c|c|c|c|c|c|c|c|c|}
\hline Waste & \multicolumn{6}{|c|}{ LAWB2 } & \multicolumn{6}{|c|}{ LAWA1 } \\
\hline \multirow{3}{*}{ Test } & \multirow{2}{*}{\multicolumn{3}{|c|}{$\begin{array}{c}\text { B3 } \\
\text { DWV-F-58A }\end{array}$}} & \multirow{2}{*}{\multicolumn{3}{|c|}{\begin{tabular}{|c|} 
B4 \\
DWV-F-126A \\
\end{tabular}}} & \multirow{2}{*}{\multicolumn{3}{|c|}{$\begin{array}{c}\text { A3 } \\
\text { EWV-F-76A }\end{array}$}} & \multirow{2}{*}{\multicolumn{3}{|c|}{\begin{tabular}{|c|} 
A4 \\
EWV-F-129A \\
\end{tabular}}} \\
\hline & & & & & & & & & & & & \\
\hline & Target & XRF & DCP & Target & XRF & DCP & Target & XRF & DCP & Target & XRF & DCP \\
\hline $\mathrm{Al}_{2} \mathrm{O}_{3}$ & 10.06 & 9.50 & 9.76 & 10.05 & 9.54 & 9.81 & 10.62 & 10.71 & 11.08 & 10.61 & 10.40 & 10.82 \\
\hline $\mathrm{B}_{2} \mathrm{O}_{3} *$ & 10.91 & $10.91^{*}$ & 10.89 & 10.90 & $10.90 *$ & 11.21 & 12.75 & $12.75 *$ & 12.85 & 12.74 & $12.74 *$ & 12.52 \\
\hline $\mathrm{CaO}$ & 10.11 & \begin{tabular}{|l|}
10.02 \\
\end{tabular} & 9.11 & 10.10 & \begin{tabular}{|l|}
9.89 \\
\end{tabular} & 9.21 & 6.47 & 5.72 & 5.93 & 6.46 & 5.77 & 6.04 \\
\hline $\mathrm{Cl}$ & 0.01 & $<0.01$ & NA & 0.01 & $<0.01$ & NA & 0.65 & 0.05 & NA & 0.65 & 0.33 & NA \\
\hline $\mathrm{Cr}_{2} \mathrm{O}_{3}$ & 0.11 & 0.21 & 0.19 & 0.11 & 0.20 & 0.19 & 0.52 & 0.59 & 0.58 & 0.52 & 0.65 & 0.59 \\
\hline $\mathrm{F}$ & 0.07 & NA & NA & 0.07 & NA & NA & $<0.01$ & NA & NA & $<0.01$ & NA & NA \\
\hline $\mathrm{Fe}_{2} \mathrm{O}_{3}$ & 1.14 & 1.35 & 1.32 & 1.13 & 1.20 & 1.23 & \begin{tabular}{|l|}
0.90 \\
\end{tabular} & 0.91 & 0.91 & \begin{tabular}{|l|}
0.90 \\
\end{tabular} & 0.83 & 0.91 \\
\hline $\mathrm{I}$ & 0.10 & $<0.01$ & NA & 0.10 & $<0.01$ & NA & 0.10 & 0.03 & NA & 0.10 & 0.07 & NA \\
\hline $\mathrm{K}_{2} \mathrm{O}$ & 0.40 & 0.60 & 0.60 & 0.40 & 0.57 & 0.58 & 0.51 & 0.57 & 0.61 & 0.51 & 0.57 & 0.65 \\
\hline $\mathrm{Li}_{2} \mathrm{O} *$ & 3.52 & $3.52 *$ & 3.33 & 3.51 & $3.51^{*}$ & 3.17 & $\S$ & $<0.01$ & 0.06 & $\S$ & $<0.01$ & 0.05 \\
\hline $\mathrm{MgO}$ & 1.14 & 1.00 & 1.23 & 1.13 & 0.93 & 1.07 & 0.90 & 0.68 & 0.86 & 0.90 & 0.93 & 0.94 \\
\hline $\mathrm{Na}_{2} \mathrm{O}$ & 9.96 & 10.13 & 9.36 & 9.95 & 10.69 & 9.48 & 22.93 & 22.10 & 20.87 & 22.91 & 23.15 & 21.10 \\
\hline $\mathrm{P}_{2} \mathrm{O}_{5}$ & 0.03 & 0.07 & 0.20 & 0.03 & 0.07 & 0.14 & $\S$ & 0.02 & 0.21 & $\S$ & 0.02 & 0.12 \\
\hline $\mathrm{SiO}_{2}$ & \begin{tabular}{|l|}
42.73 \\
\end{tabular} & 43.71 & 42.91 & 42.69 & 43.79 & 43.00 & 34.75 & \begin{tabular}{|l|}
37.19 \\
\end{tabular} & 34.46 & 34.72 & 35.49 & 34.73 \\
\hline $\mathrm{SnO}_{2}$ & $\S$ & $<0.01$ & 0.02 & $\S$ & $<0.01$ & 0.03 & 1.00 & 1.25 & 1.10 & 1.00 & 1.17 & 1.14 \\
\hline $\mathrm{SO}_{3}$ & 1.50 & 0.54 & NA & 1.60 & 0.53 & NA & 0.95 & 0.76 & NA & 1.05 & 1.04 & NA \\
\hline $\mathrm{TiO}_{2}$ & $\S$ & 0.23 & 0.24 & $\S$ & 0.22 & 0.24 & $\S$ & 0.11 & 0.14 & $\S$ & 0.11 & 0.14 \\
\hline $\mathrm{V}_{2} \mathrm{O}_{5}$ & 1.23 & 1.50 & 1.35 & 1.22 & 1.46 & 1.34 & 0.97 & 0.84 & 0.78 & 0.97 & 1.16 & 1.11 \\
\hline $\mathrm{ZnO}$ & 3.51 & 3.05 & 3.09 & 3.50 & 2.82 & 3.01 & 2.99 & 2.83 & 3.11 & 2.98 & 2.76 & 3.07 \\
\hline $\mathrm{ZrO}_{2}$ & 3.51 & 3.66 & 3.42 & 3.50 & 3.66 & 3.33 & 2.99 & 2.89 & 2.79 & 2.98 & 2.79 & 2.75 \\
\hline Sum & 100.00 & 100.00 & 97.02 & 100.00 & 100.00 & 97.04 & 100.00 & 100.00 & 96.34 & 100.00 & 100.00 & 96.68 \\
\hline
\end{tabular}


The Catholic University of America Vitreous State Laboratory
ORP-56322, Rev. 0 LAW Envelope A and B Glass Formulations Testing to Increase Waste Loading Final Report, VSL-06R6900-1, Rev. 0

Table 3.1. Summary of LAWB DM10 Test Conditions and Results.

\begin{tabular}{|c|c|c|c|c|c|c|c|c|c|}
\hline \multicolumn{3}{|c|}{ Test } & B1A & B1B & B1C & B1D & B1E & B2A & B2B \\
\hline \multirow{3}{*}{ Time } & \multicolumn{2}{|c|}{ Feed Start } & $\begin{array}{l}\text { 8/8/05 } \\
09: 15\end{array}$ & $\begin{array}{l}8 / 8 / 05 \\
23: 27\end{array}$ & $\begin{array}{l}8 / 9 / 05 \\
13: 53\end{array}$ & $\begin{array}{c}8 / 10 / 05 \\
4: 25\end{array}$ & $\begin{array}{c}8 / 10 / 05 \\
19: 15\end{array}$ & $\begin{array}{c}\text { 8/11/05 } \\
09: 44\end{array}$ & $\begin{array}{c}\text { 8/12/05 } \\
00: 15\end{array}$ \\
\hline & \multicolumn{2}{|c|}{ Feed End } & $\begin{array}{l}8 / 8 / 05 \\
23: 00\end{array}$ & $\begin{array}{l}8 / 9 / 05 \\
13: 22\end{array}$ & $\begin{array}{c}8 / 10 / 05 \\
3: 53\end{array}$ & $\begin{array}{c}8 / 10 / 05 \\
18: 25\end{array}$ & $\begin{array}{c}\text { 8/11/05 } \\
09: 25\end{array}$ & $\begin{array}{c}8 / 11 / 05 \\
23: 44\end{array}$ & $\begin{array}{c}8 / 12 / 05 \\
14: 30\end{array}$ \\
\hline & \multicolumn{2}{|c|}{ Net Slurry Feeding (hr) } & 13.75 & 13.9 & 14.0 & 14.0 & 14.2 & 14.0 & 14.25 \\
\hline \multirow{3}{*}{$\begin{array}{c}\text { Glass } \\
\text { Temperature }\left({ }^{\circ} \mathrm{C}\right)\end{array}$} & \multicolumn{2}{|c|}{ Target } & 1150 & 1150 & 1150 & 1150 & 1150 & 1175 & 1175 \\
\hline & \multirow{2}{*}{$\begin{array}{c}\text { Highest } \\
\text { Average } \\
\text { Measured }^{\$}\end{array}$} & Temperature & 1152 & 1152 & 1152 & 1152 & 1152 & 1178 & 1178 \\
\hline & & Location & $\begin{array}{l}\text { 2" from } \\
\text { floor }\end{array}$ & $\begin{array}{l}2 \text { " from } \\
\text { floor }\end{array}$ & $\begin{array}{l}2 ” \text { from } \\
\text { floor }\end{array}$ & $\begin{array}{l}2 \text { " from } \\
\text { floor }\end{array}$ & $\begin{array}{l}2 \text { " from } \\
\text { floor }\end{array}$ & $\begin{array}{l}\text { 2" from } \\
\text { floor }\end{array}$ & $\begin{array}{l}\text { 2" from } \\
\text { floor }\end{array}$ \\
\hline \multirow{4}{*}{ Feed } & \multicolumn{2}{|c|}{$\mathrm{wt} \% \mathrm{Na}_{2} \mathrm{O}$ as glass } & 10.0 & 10.0 & 10.0 & 10.0 & 10.0 & 10.0 & 10.0 \\
\hline & \multicolumn{2}{|c|}{$\mathrm{wt} \% \mathrm{SO}_{3}$ as glass } & 1.0 & 1.2 & 1.4 & 1.6 & 1.5 & 1.6 & 1.7 \\
\hline & \multicolumn{2}{|c|}{ Glass Conversion Ratio } & 0.5 & 0.5 & 0.5 & 0.5 & 0.5 & 0.5 & 0.5 \\
\hline & \multicolumn{2}{|c|}{ Feed Used (kg) } & 55.2 & 55.3 & 55.9 & 55.2 & 55.1 & 55.7 & 55.8 \\
\hline \multicolumn{3}{|c|}{ Average Production Rate $\left(\mathrm{kg} / \mathrm{m}^{2} / \text { day }\right)^{*}$} & 2294 & 2273 & 2282 & 2254 & 2235 & 2274 & 2267 \\
\hline \multicolumn{3}{|c|}{ Average Bubbling Rate (lpm) } & 2.6 & 2.2 & 1.4 & 1.7 & 1.7 & 0.8 & 1.0 \\
\hline \multirow{4}{*}{ Product } & \multicolumn{2}{|c|}{ Measured wt $\% \mathrm{Na}_{2} \mathrm{O}$} & 9.9 & 10.5 & 10.9 & 10.7 & 10.7 & 10.5 & 11.1 \\
\hline & \multicolumn{2}{|c|}{$\begin{array}{l}\text { Secondary Phases on Melt } \\
\text { Surface at Test End }\end{array}$} & No & No & No & Yes & No & No & Yes \\
\hline & \multicolumn{2}{|c|}{ Measured wt\% $\mathrm{SO}_{3}$} & 0.82 & 1.01 & 1.21 & 1.41 & 1.33 & 1.32 & 1.46 \\
\hline & \multicolumn{2}{|c|}{ \% Feed Sulfur in Glass Product } & 82 & 84 & 86 & 88 & 89 & 83 & 86 \\
\hline \multirow{4}{*}{$\begin{array}{c}\text { Average } \\
\text { Concentrations } \\
\text { monitored in } \\
\text { stack exhaust by } \\
\text { FTIR (ppmv) }\end{array}$} & \multicolumn{2}{|c|}{ NO } & 117 & 102 & 113 & 111 & 110 & 115 & 131 \\
\hline & \multicolumn{2}{|c|}{$\mathrm{NO}_{2}$} & 1.1 & 1.1 & 1.0 & $<1$ & $<1$ & $<1$ & $<1$ \\
\hline & \multicolumn{2}{|c|}{$\mathrm{CO}$} & 3.9 & 3.3 & 4.0 & 2.7 & 2.3 & 2.7 & 4.7 \\
\hline & \multicolumn{2}{|c|}{$\mathrm{NH}_{3}$} & 12.4 & 10.2 & 11.3 & 11.6 & 10.4 & 12.5 & 10.7 \\
\hline
\end{tabular}

* - Glass production rates calculated from feed data

\$ - Values given are the highest test average temperature from the thermocouples at 2”, 4” and 6” from the melt pool floor. 
The Catholic University of America Vitreous State Laboratory

Table 3.2. Summary of LAWA DM10 Test Conditions and Results.

\begin{tabular}{|c|c|c|c|c|c|c|c|}
\hline \multicolumn{3}{|c|}{ Test } & A1A & A1B & A2A & A2B & A2C \\
\hline \multirow{5}{*}{ Time } & \multirow{2}{*}{\multicolumn{2}{|c|}{ Feed Start }} & $9 / 28 / 05$ & $9 / 28 / 05$ & 9/29/05 & $9 / 30 / 05$ & $10 / 1 / 05$ \\
\hline & & & 06:46 & 22:05 & $20: 25$ & $11: 17$ & 07:15 \\
\hline & \multirow{2}{*}{\multicolumn{2}{|c|}{ Feed End }} & $9 / 28 / 05$ & $9 / 29 / 05$ & $9 / 30 / 05$ & $10 / 1 / 05$ & $10 / 2 / 05$ \\
\hline & & & $21: 30$ & $13: 45$ & $11: 00$ & 03:00 & 01:00 \\
\hline & \multicolumn{2}{|c|}{ Net Slurry Feeding (hr) } & 14.8 & 15.7 & 14.6 & 15.7 & $16.7^{\#}$ \\
\hline \multirow{3}{*}{$\begin{array}{c}\text { Glass } \\
\text { Temperature } \\
\left(\mathrm{C}^{\circ}\right)\end{array}$} & \multicolumn{2}{|c|}{ Target } & 1150 & 1150 & 1175 & 1175 & 1175 \\
\hline & \multirow{2}{*}{$\begin{array}{l}\text { Highest } \\
\text { Average } \\
\text { Measured }^{\$}\end{array}$} & Temperature & 1149 & 1151 & 1165 & 1169 & 1156 \\
\hline & & Location & $\begin{array}{l}\text { 2”, 4”, 6” } \\
\text { from floor }\end{array}$ & $\begin{array}{l}\text { 2" from } \\
\text { floor }\end{array}$ & $\begin{array}{l}\text { 6" from } \\
\text { floor }\end{array}$ & $\begin{array}{l}\text { 2" from } \\
\text { floor }\end{array}$ & $\begin{array}{l}\text { 2" from } \\
\text { floor }\end{array}$ \\
\hline \multirow{4}{*}{ Feed } & \multicolumn{2}{|c|}{$\mathrm{wt} \% \mathrm{Na}_{2} \mathrm{O}$ as glass } & 23.0 & 23.0 & 23.0 & 23.0 & 23.0 \\
\hline & \multicolumn{2}{|c|}{$\mathrm{wt} \% \mathrm{SO}_{3}$ as glass } & 1.0 & 1.2 & 0.8 & 1.1 & 1.05 \\
\hline & \multicolumn{2}{|c|}{ Glass Conversion Ratio } & 0.469 & 0.469 & 0.469 & 0.469 & 0.469 \\
\hline & \multicolumn{2}{|c|}{ Feed Used (kg) } & 56.1 & 60.2 & 58.0 & 63.2 & 58.4 \\
\hline \multicolumn{3}{|c|}{ Average Production Rate $\left(\mathrm{kg} / \mathrm{m}^{2} / \text { day }\right)^{*}$} & 2032 & 2045 & 2128 & 2157 & 1874 \\
\hline \multicolumn{3}{|c|}{ Average Bubbling Rate (lpm) } & 3.3 & 4.0 & 3.5 & 2.7 & 1.9 \\
\hline \multirow{4}{*}{ Product } & \multicolumn{2}{|c|}{ Measured wt $\% \mathrm{Na}_{2} \mathrm{O}$} & 22.0 & 22.2 & 23.3 & 23.6 & 23.7 \\
\hline & \multicolumn{2}{|c|}{$\begin{array}{l}\text { Secondary Phases on Melt } \\
\text { Surface at Test End }\end{array}$} & No & Yes & No & Yes & No \\
\hline & \multicolumn{2}{|c|}{ Measured wt $\% \mathrm{SO}_{3}$} & 0.88 & 1.20 & 0.73 & 0.95 & 0.96 \\
\hline & \multicolumn{2}{|c|}{$\begin{array}{c}\% \text { Feed Sulfur in Glass } \\
\text { Product }\end{array}$} & 88 & 100 & 91 & 86 & 91 \\
\hline \multirow{4}{*}{$\begin{array}{c}\text { Average } \\
\text { Concentrations } \\
\text { monitored in } \\
\text { stack exhaust by } \\
\text { FTIR (ppmv) }\end{array}$} & \multicolumn{2}{|c|}{ NO } & 227 & 402 & 390 & 398 & 360 \\
\hline & \multicolumn{2}{|c|}{$\mathrm{NO}_{2}$} & 35.6 & 57.1 & 62.0 & 61.8 & 47.0 \\
\hline & \multicolumn{2}{|c|}{$\mathrm{CO}$} & 7.0 & 11.4 & 10.7 & 10.4 & 10.0 \\
\hline & \multicolumn{2}{|c|}{$\mathrm{NH}_{3}$} & 29.6 & 25.6 & 27.8 & 35.5 & 32.6 \\
\hline
\end{tabular}

* - Glass production rates calculated from feed data

$\#$ - Net time reflects the total time interval minus 1 hour and 5 minute down to stabilize cold cap.

$\$$ - Values given are the highest test average temperature from the thermocouples at 2", 4" and 6" from the melt pool floor. 
Table 3.3. Listing of LAWB DM10 Glasses Discharged, Masses, and Measured Sulfur and Iodine Contents.

\begin{tabular}{|c|c|c|c|c|c|c|c|c|}
\hline \multirow{2}{*}{ Test } & \multirow{2}{*}{$\mathbf{T}\left({ }^{\circ} \mathrm{C}\right)$} & \multirow{2}{*}{ Date } & \multirow{2}{*}{ Name } & \multirow{2}{*}{$\begin{array}{c}\text { Mass } \\
\text { (kg) }\end{array}$} & \multirow{2}{*}{$\begin{array}{c}\text { Cumulative } \\
\text { Mass (kg) }\end{array}$} & \multicolumn{2}{|c|}{$\mathrm{SO}_{3}(\mathrm{wt} \%)$} & \multirow{2}{*}{$\frac{\text { I (wt \%) }}{\text { Measured }}$} \\
\hline & & & & & & Target & Measured & \\
\hline \multirow{11}{*}{ B1A } & \multirow{37}{*}{1150} & \multirow{11}{*}{ 8/8/05 } & K10-G-88A & - & - & \multirow{10}{*}{1.00} & - & - \\
\hline & & & K10-G-88B & 4.48 & 4.48 & & NA & NA \\
\hline & & & K10-G-99A & - & - & & - & - \\
\hline & & & K10-G-99B & 4.58 & 9.06 & & 0.71 & 0.02 \\
\hline & & & K10-G-99C & - & - & & - & - \\
\hline & & & K10-G-99D & 4.38 & 13.44 & & 0.77 & 0.02 \\
\hline & & & K10-G-100A & - & - & & - & - \\
\hline & & & K10-G-100B & 4.62 & 18.06 & & 0.79 & 0.02 \\
\hline & & & K10-G-100C & - & - & & - & - \\
\hline & & & K10-G-100D & 4.76 & 22.82 & & 0.82 & 0.02 \\
\hline & & & K10-G-100E & - & - & \multirow{11}{*}{1.20} & - & - \\
\hline \multirow{10}{*}{ B1B } & & \multirow{19}{*}{ 8/9/05 } & K10-G-101A & 6.16 & 28.98 & & 0.87 & 0.02 \\
\hline & & & K10-G-110B & - & - & & - & - \\
\hline & & & K10-G-101C & 5.96 & 34.94 & & 0.92 & 0.02 \\
\hline & & & K10-G-105A & - & - & & - & - \\
\hline & & & K10-G-105B & 4.80 & 39.74 & & 0.95 & 0.02 \\
\hline & & & K10-G-105C & - & - & & - & - \\
\hline & & & K10-G-105D & 4.36 & 44.10 & & 0.96 & 0.02 \\
\hline & & & K10-G-105E & - & - & & - & - \\
\hline & & & K10-G-109A & 4.34 & 48.44 & & 0.95 & 0.02 \\
\hline & & & K10-G-109B & 2.36 & 50.80 & & 1.01 & 0.02 \\
\hline \multirow{12}{*}{ B1C } & & & K10-G-109C & - & - & \multirow{12}{*}{1.40} & - & - \\
\hline & & & K10-G-109D & 5.14 & 55.94 & & 1.05 & 0.02 \\
\hline & & & K10-G-111A & - & - & & - & - \\
\hline & & & K10-G-111B & 4.16 & 60.10 & & 1.11 & 0.03 \\
\hline & & & K10-G-111C & - & - & & - & - \\
\hline & & & K10-G-111D & 4.70 & 64.80 & & 1.14 & 0.03 \\
\hline & & & K10-G-115A & - & - & & - & - \\
\hline & & & K10-G-115B & 4.00 & 68.80 & & 1.17 & 0.03 \\
\hline & & & K10-G-115C & - & - & & - & - \\
\hline & & \multirow{7}{*}{ 8/10/05 } & K10-G-115D & 5.62 & 74.42 & & 1.17 & 0.02 \\
\hline & & & K10-G-115E & - & - & & - & - \\
\hline & & & K10-G-115F & 5.20 & 79.62 & & 1.21 & 0.02 \\
\hline \multirow{4}{*}{ B1D } & & & K10-G-118A & - & - & \multirow{4}{*}{1.60} & - & - \\
\hline & & & K10-G-118B & 4.80 & 84.42 & & 1.23 & 0.02 \\
\hline & & & K10-G-123A & - & - & & - & - \\
\hline & & & K10-G-123B & 5.52 & 89.94 & & 1.30 & 0.03 \\
\hline
\end{tabular}

- Empty data field

NA - Not analyzed 
Table 3.3. Listing of LAWB DM10 Glasses Discharged, Masses, and Measured Sulfur and Iodine Contents (continued).

\begin{tabular}{|c|c|c|c|c|c|c|c|c|}
\hline \multirow{2}{*}{ Test } & \multirow{2}{*}{$\mathbf{T}\left({ }^{\circ} \mathbf{C}\right)$} & \multirow{2}{*}{ Date } & \multirow{2}{*}{ Name } & \multirow{2}{*}{$\begin{array}{c}\text { Mass } \\
\text { (kg) }\end{array}$} & \multirow{2}{*}{$\begin{array}{l}\text { Cumulative } \\
\text { Mass (kg) }\end{array}$} & \multicolumn{2}{|c|}{$\mathrm{SO}_{3}(\mathrm{wt} \%)$} & \multirow{2}{*}{$\frac{\text { I (wt \%) }}{\text { Measured }}$} \\
\hline & & & & & & Target & Measured & \\
\hline \multirow{7}{*}{ B1D } & \multirow{18}{*}{1150} & \multirow{10}{*}{ 8/10/05 } & K10-G-123C & - & - & \multirow{7}{*}{1.60} & - & - \\
\hline & & & K10-G-124A & 4.34 & 94.28 & & 1.41 & 0.02 \\
\hline & & & K10-G-124B & - & - & & - & - \\
\hline & & & K10-G-124C & 3.82 & 98.10 & & 1.40 & 0.02 \\
\hline & & & K10-G-124D & - & - & & - & - \\
\hline & & & K10-G-124E & 5.08 & 103.18 & & 1.41 & 0.03 \\
\hline & & & K10-G-124F & 3.22 & 106.40 & & 1.52 & 0.03 \\
\hline \multirow{11}{*}{ B1E } & & & K10-G-125A & - & - & \multirow{11}{*}{1.50} & - & - \\
\hline & & & K10-G-125B & 5.14 & 111.54 & & 1.41 & 0.02 \\
\hline & & & K10-G-129A & - & - & & - & - \\
\hline & & \multirow{18}{*}{ 8/11/05 } & K10-G-129B & 4.14 & 115.68 & & 1.42 & 0.03 \\
\hline & & & K10-G-129C & - & - & & - & - \\
\hline & & & K10-G-129D & 3.62 & 119.30 & & 1.39 & 0.02 \\
\hline & & & K10-G-129E & - & - & & - & - \\
\hline & & & K10-G-129F & 4.64 & 123.94 & & 1.38 & 0.02 \\
\hline & & & K10-G-129G & - & - & & - & - \\
\hline & & & K10-G-129H & 4.16 & 128.10 & & 1.36 & 0.03 \\
\hline & & & K10-G-135A & 2.40 & 130.50 & & 1.33 & 0.02 \\
\hline \multirow{10}{*}{ B2A } & \multirow{20}{*}{1175} & & K10-G-135B & - & - & \multirow{10}{*}{1.60} & - & - \\
\hline & & & K10-G-136A & 6.56 & 137.06 & & 1.35 & 0.03 \\
\hline & & & K10-G-136B & - & - & & - & - \\
\hline & & & K10-G-136C & 6.14 & 143.20 & & 1.35 & 0.03 \\
\hline & & & K10-G-141A & - & - & & - & - \\
\hline & & & K10-G-141B & 5.26 & 148.46 & & 1.34 & 0.03 \\
\hline & & & K10-G-141C & - & - & & - & - \\
\hline & & & K10-G-141D & 5.14 & 153.60 & & 1.38 & 0.03 \\
\hline & & & K10-G-141E & - & - & & - & - \\
\hline & & & K10-G-141F & 5.04 & 158.64 & & 1.32 & 0.03 \\
\hline \multirow{10}{*}{ B2B } & & \multirow{10}{*}{$8 / 12 / 05$} & K10-G-144A & - & - & \multirow{10}{*}{1.70} & - & - \\
\hline & & & K10-G-144B & 5.48 & 164.12 & & 1.43 & 0.02 \\
\hline & & & K10-G-149A & - & - & & - & - \\
\hline & & & K10-G-149B & 5.38 & 169.50 & & 1.45 & 0.02 \\
\hline & & & K10-G-149C & - & - & & - & - \\
\hline & & & K10-G-149D & 5.30 & 174.80 & & 1.41 & 0.02 \\
\hline & & & K10-G-149E & - & - & & - & - \\
\hline & & & K10-G-149F & 5.54 & 180.34 & & 1.46 & 0.02 \\
\hline & & & K10-G-150A & - & - & & - & - \\
\hline & & & K10-G-150B & 5.12 & 185.46 & & 1.58 & 0.03 \\
\hline
\end{tabular}

- Empty data field 
Table 3.4. Listing of LAWA DM10 Glasses Discharged, Masses, and Measured Sulfur and Iodine Contents.

\begin{tabular}{|c|c|c|c|c|c|c|c|c|}
\hline \multirow{2}{*}{ Test } & \multirow{2}{*}{$\mathbf{T}\left({ }^{\circ} \mathbf{C}\right)$} & \multirow{2}{*}{ Date } & \multirow{2}{*}{ Sample Name } & \multirow{2}{*}{$\begin{array}{c}\text { Mass } \\
\text { (kg) }\end{array}$} & \multirow{2}{*}{$\begin{array}{c}\text { Cumulative } \\
\text { Mass (kg) }\end{array}$} & \multicolumn{2}{|c|}{$\mathrm{SO}_{3}(\mathrm{wt} \%)$} & \multirow{2}{*}{$\begin{array}{c}\text { I (wt\%) } \\
\text { Measured }\end{array}$} \\
\hline & & & & & & Target & Measured & \\
\hline \multirow{9}{*}{ A1A } & \multirow{20}{*}{1150} & \multirow{10}{*}{ 9/28/05 } & L10-G-20A & - & - & \multirow{9}{*}{1.00} & - & - \\
\hline & & & L10-G-20B & 6.02 & 6.02 & & 0.72 & 0.01 \\
\hline & & & L10-G-20C & - & - & & - & - \\
\hline & & & L10-G-21A & 5.54 & 11.56 & & 0.81 & 0.02 \\
\hline & & & L10-G-21B & - & - & & - & - \\
\hline & & & L10-G-21C & 5.16 & 16.72 & & 0.83 & 0.03 \\
\hline & & & L10-G-22A & - & - & & - & - \\
\hline & & & L10-G-22B & 5.06 & 21.78 & & 0.84 & 0.03 \\
\hline & & & L10-G-22C & 1.84 & 23.62 & & 0.88 & 0.03 \\
\hline \multirow{11}{*}{ A1B } & & & L10-G-26A & - & - & \multirow{11}{*}{1.20} & - & - \\
\hline & & \multirow{13}{*}{ 9/29/05 } & L10-G-26B & 3.79 & 27.41 & & 0.93 & 0.03 \\
\hline & & & L10-G-27A & - & - & & - & - \\
\hline & & & L10-G-27B & 5.26 & 32.67 & & 1.01 & 0.03 \\
\hline & & & L10-G-27C & - & - & & - & - \\
\hline & & & L10-G-27D & 4.30 & 36.97 & & 1.24 & 0.04 \\
\hline & & & L10-G-28A & - & - & & - & - \\
\hline & & & L10-G-28B & 5.48 & 42.45 & & 1.03 & 0.03 \\
\hline & & & L10-G-28C & - & - & & - & - \\
\hline & & & L10-G-28D & 5.80 & 48.25 & & 1.09 & 0.04 \\
\hline & & & L10-G-32A & 1.68 & 49.93 & & 1.20 & 0.04 \\
\hline \multirow{9}{*}{ A2A } & \multirow{20}{*}{1175} & & L10-G-35A & - & - & \multirow{9}{*}{0.80} & - & - \\
\hline & & & L10-G-35B & 5.04 & 54.97 & & 0.96 & 0.03 \\
\hline & & & L10-G-35C & - & - & & - & - \\
\hline & & \multirow{17}{*}{ 9/30/05 } & L10-G-38A & 5.72 & 60.69 & & 0.87 & 0.04 \\
\hline & & & L10-G-38B & - & - & & - & - \\
\hline & & & L10-G-38C & 4.26 & 64.95 & & 0.80 & 0.03 \\
\hline & & & L10-G-40A & - & - & & - & - \\
\hline & & & L10-G-40B & 6.00 & 70.95 & & 0.73 & 0.03 \\
\hline & & & L10-G-43A & - & - & & - & - \\
\hline \multirow{11}{*}{ A2B } & & & L10-G-43B & 6.64 & 77.59 & \multirow{11}{*}{1.10} & 0.67 & 0.03 \\
\hline & & & L10-G-44A & - & - & & - & - \\
\hline & & & L10-G-44B & 5.12 & 82.71 & & 0.76 & 0.03 \\
\hline & & & L10-G-47A & - & - & & - & - \\
\hline & & & L10-G-47B & 3.50 & 86.21 & & 0.81 & 0.03 \\
\hline & & & L10-G-47C & - & - & & - & - \\
\hline & & & L10-G-47D & 5.24 & 91.45 & & 0.85 & 0.04 \\
\hline & & & L10-G-48A & - & - & & - & - \\
\hline & & & L10-G-48B & 3.40 & 94.85 & & 0.88 & 0.03 \\
\hline & & & L10-G-48C & - & - & & - & - \\
\hline & & & L10-G-48D & 5.42 & 100.27 & & 0.95 & 0.03 \\
\hline
\end{tabular}

- Empty data field 
Table 3.4. Listing of LAWA DM10 Glasses Discharged, Masses, and Measured Sulfur and Iodine Contents (continued).

\begin{tabular}{|c|c|c|c|c|c|c|c|c|}
\hline \multirow{2}{*}{ Test } & \multirow{2}{*}{$\mathbf{T}\left({ }^{\circ} \mathrm{C}\right)$} & \multirow{2}{*}{ Date } & \multirow{2}{*}{ Sample Name } & \multirow{2}{*}{$\begin{array}{c}\text { Mass } \\
\text { (kg) }\end{array}$} & \multirow{2}{*}{$\begin{array}{c}\text { Cumulati } \\
\text { ve Mass } \\
\text { (kg) }\end{array}$} & \multicolumn{2}{|c|}{$\mathrm{SO}_{3}(\mathrm{wt} \%)$} & \multirow{2}{*}{$\begin{array}{l}\text { I (wt\%) } \\
\text { Measured }\end{array}$} \\
\hline & & & & & & Target & Measured & \\
\hline \multirow{2}{*}{ A2B } & \multirow{16}{*}{1175} & \multirow{16}{*}{ 9/31/05 } & L10-G-52A & - & - & 110 & - & - \\
\hline & & & L10-G-52B & 4.36 & 104.63 & 1.10 & 0.95 & 0.04 \\
\hline \multirow{14}{*}{ A2C } & & & L10-G-55A & - & - & \multirow{14}{*}{1.05} & - & - \\
\hline & & & L10-G-55B & 4.48 & 109.11 & & 0.92 & 0.02 \\
\hline & & & L10-G-56A & - & - & & - & - \\
\hline & & & L10-G-56B & 3.54 & 112.65 & & 0.93 & 0.03 \\
\hline & & & L10-G-56C & - & - & & - & - \\
\hline & & & L10-G-56D & 4.00 & 116.65 & & 0.97 & 0.03 \\
\hline & & & L10-G-61A & - & - & & - & - \\
\hline & & & L10-G-61B & 3.72 & 120.37 & & 0.99 & 0.03 \\
\hline & & & L10-G-61C & - & - & & - & - \\
\hline & & & L10-G-61D & 4.08 & 124.45 & & 0.96 & 0.03 \\
\hline & & & L10-G-62A & - & - & & - & - \\
\hline & & & L10-G-62B & 3.50 & 127.95 & & 0.96 & 0.03 \\
\hline & & & L10-G-62C & - & - & & - & - \\
\hline & & & L10-G-63A & 4.00 & 131.95 & & 1.01 & 0.03 \\
\hline
\end{tabular}

- Empty data field 
Table 3.5. Dip samples and Presence of Sulfate Layer During DM10 Melter Tests.

\begin{tabular}{|c|c|c|c|c|c|c|c|}
\hline $\begin{array}{l}\text { Waste } \\
\text { Type }\end{array}$ & $\begin{array}{c}\mathrm{T} \\
\left({ }^{\circ} \mathrm{C}\right)\end{array}$ & Test & $\begin{array}{c}\text { Sampling } \\
\text { Date }\end{array}$ & Sample Name & $\begin{array}{c}\text { Target } \mathrm{SO}_{3} \\
\text { (wt \%) }\end{array}$ & $\begin{array}{c}\text { Glass } \\
\text { Produced } \\
\text { for each } \\
\text { composition } \\
\text { (kg) }\end{array}$ & $\begin{array}{c}\text { Secondary } \\
\text { Sulfate Phase }\end{array}$ \\
\hline \multirow{10}{*}{ LAWB } & \multirow{7}{*}{1150} & B1A & $8 / 8 / 05$ & K10-D-101A & 1.0 & 22.82 & No \\
\hline & & B1B & 8/9/05 & K10-D-109A & 1.2 & 50.80 & No \\
\hline & & B1C & \multirow{4}{*}{ 8/10/05 } & K10-D-118A & 1.4 & 79.62 & No \\
\hline & & \multirow{3}{*}{ B1D } & & K10-D-125A & \multirow{3}{*}{1.6} & \multirow{3}{*}{106.40} & Yes \\
\hline & & & & K10-D-125B & & & No \\
\hline & & & & K10-D-125C & & & No \\
\hline & & B1E & \multirow{4}{*}{ 8/11/05 } & K10-D-135A & 1.5 & 130.5 & No \\
\hline & \multirow{3}{*}{1175} & B2A & & K10-D-144A & 1.6 & 158.64 & No \\
\hline & & \multirow{2}{*}{ B2B } & & K10-D-150A & \multirow{2}{*}{1.7} & \multirow{2}{*}{185.46} & Yes \\
\hline & & & & K10-D-150B & & & Yes \\
\hline \multirow{15}{*}{ LAWA } & \multirow{7}{*}{1150} & A1A & $9 / 28 / 05$ & L10-D-22A & 1.0 & 23.62 & No \\
\hline & & \multirow{6}{*}{ A1B } & \multirow{6}{*}{ 9/29/05 } & L10-D-32A & \multirow{6}{*}{1.2} & \multirow{6}{*}{49.93} & Yes \\
\hline & & & & L10-D-32B & & & Yes \\
\hline & & & & L10-D-32C* & & & Yes \\
\hline & & & & L10-D-33A* & & & Yes \\
\hline & & & & L10-D-33B* & & & Yes \\
\hline & & & & L10-D-33C* & & & No \\
\hline & & A2A & & None & 0.8 & 74.27 & NA \\
\hline & & & & L10-D-53A & & & Yes \\
\hline & & A2B & 9/30/05 & L10-D-53B & 1.1 & 104.63 & Yes \\
\hline & & & & L10-D-53C* & & & No \\
\hline & 1175 & & & L10-D-62A & & & No \\
\hline & & ת2 & & L10-D-63A & & & No \\
\hline & & A2C & 10/2/05 & L10-D-63B & 1.05 & 131.95 & No \\
\hline & & & & L10-D-63C & & & No \\
\hline
\end{tabular}

* - Samples taken after long periods of bubbling and/or water feeding intended to remove secondary sulfate phase. 
The Catholic University of America Vitreous State Laboratory
ORP-56322, Rev. 0 LAW Envelope A and B Glass Formulations Testing to Increase Waste Loading Final Report, VSL-06R6900-1, Rev. 0

Table 4.1. Summary of DM100 Test Conditions and Results.

\begin{tabular}{|c|c|c|c|c|c|}
\hline & \multirow{2}{*}{ Test } & \multicolumn{2}{|c|}{ LAW B } & \multicolumn{2}{|c|}{ LAW A } \\
\hline & & B3 & B4 & A3 & A4 \\
\hline \multirow{6}{*}{ Time } & Feed Start & $\begin{array}{c}9 / 19 / 2005 \\
7: 00\end{array}$ & $\begin{array}{c}9 / 22 / 2005 \\
20: 41\end{array}$ & $\begin{array}{c}10 / 5 / 2005 \\
6: 45\end{array}$ & $\begin{array}{c}10 / 8 / 2005 \\
21: 00\end{array}$ \\
\hline & Feed End & $\begin{array}{c}\text { 9/22/05 } \\
20: 11\end{array}$ & $\begin{array}{c}9 / 25 / 05 \\
9: 00\end{array}$ & $\begin{array}{c}10 / 8 / 05 \\
20: 30\end{array}$ & $\begin{array}{c}10 / 11 / 05 \\
11: 00\end{array}$ \\
\hline & Water Feeding (hr) & 1.0 & NA & 1.0 & NA \\
\hline & Idling Time (hr) & 1.1 & 0.0 & 0.5 & 0.7 \\
\hline & Net Slurry Feeding (hr) & 83.1 & 60.3 & 84.2 & 60.3 \\
\hline & Cold Cap Burn-Off (hr) & NA & 1.6 & NA & 2.5 \\
\hline & Target Glass Temperature $\left({ }^{\circ} \mathrm{C}\right)$ & 1150 & 1175 & 1150 & 1175 \\
\hline \multirow{4}{*}{ Feed } & Base Glass Formulation & LAWB99 & LAWB99 & LAWA187 & LAWA187 \\
\hline & wt $\% \mathrm{Na}_{2} \mathrm{O}$ as glass & 10.0 & 10.0 & 23.0 & 23.0 \\
\hline & $\mathrm{wt} \% \mathrm{SO}_{3}$ as glass & 1.5 & 1.6 & 0.95 & 1.05 \\
\hline & Feed Used (kg) & 1682 & 1481 & 1748 & 1658 \\
\hline & Average Production Rate $\left(\mathrm{kg} / \mathrm{m}^{2} / \text { day }\right)^{*}$ & 2199 & 2703 & 2144 & 2839 \\
\hline & Steady State Production Rate (kg/m²/day) & 2250 & 2750 & 2250 & 2600 \\
\hline & Average Bubbling Rate (lpm) & 8.9 & 9.3 & 17.2 & 16.9 \\
\hline \multirow{5}{*}{ Product } & Secondary Phases on Melt Surface at Test End & No & No & No & No \\
\hline & Glass Poured (kg) & 820 & 719 & 788 & 739 \\
\hline & Measured wt\% $\mathrm{Na}_{2} \mathrm{O}$ & 10.6 & 10.3 & 22.2 & 22.3 \\
\hline & Measured wt $\% \mathrm{SO}_{3}$ & 1.14 & 1.15 & 0.77 & 0.82 \\
\hline & Measured wt\% I & 0.03 & 0.03 & 0.03 & 0.03 \\
\hline \multirow{4}{*}{$\begin{array}{c}\text { Sulfur } \\
\text { Mass } \\
\text { Balance }\end{array}$} & \% Feed Sulfur in Glass Product & 76 & 72 & 81 & 78 \\
\hline & \% Feed Sulfur in Particulate Emissions & 3.9 & 3.4 & 7.2 & 9.0 \\
\hline & \% Feed Sulfur in Gaseous Emissions & 12.2 & 19.3 & 0.2 & 0.2 \\
\hline & \% Total Sulfur Recovery & 92 & 95 & 88 & 87 \\
\hline \multirow{4}{*}{$\begin{array}{c}\text { Iodine } \\
\text { Mass } \\
\text { Balance }\end{array}$} & \% Feed Iodine in Glass Product & 30 & 30 & 30 & 30 \\
\hline & \% Feed Iodine in Particulate Emissions & $<0.1$ & $<0.1$ & 4.4 & 2.9 \\
\hline & \% Feed Iodine in Gaseous Emissions & 64.8 & 65.5 & 83.2 & 61.8 \\
\hline & \% Total Iodine Recovery & 95 & 96 & 117 & 95 \\
\hline
\end{tabular}

* - Glass production rates calculated from feed data 
The Catholic University of America Vitreous State Laboratory
ORP-56322, Rev. 0 LAW Envelope A and B Glass Formulations Testing to Increase Waste Loading Final Report, VSL-06R6900-1, Rev. 0

Table 4.2. Summary of Measured DM100 Parameters.

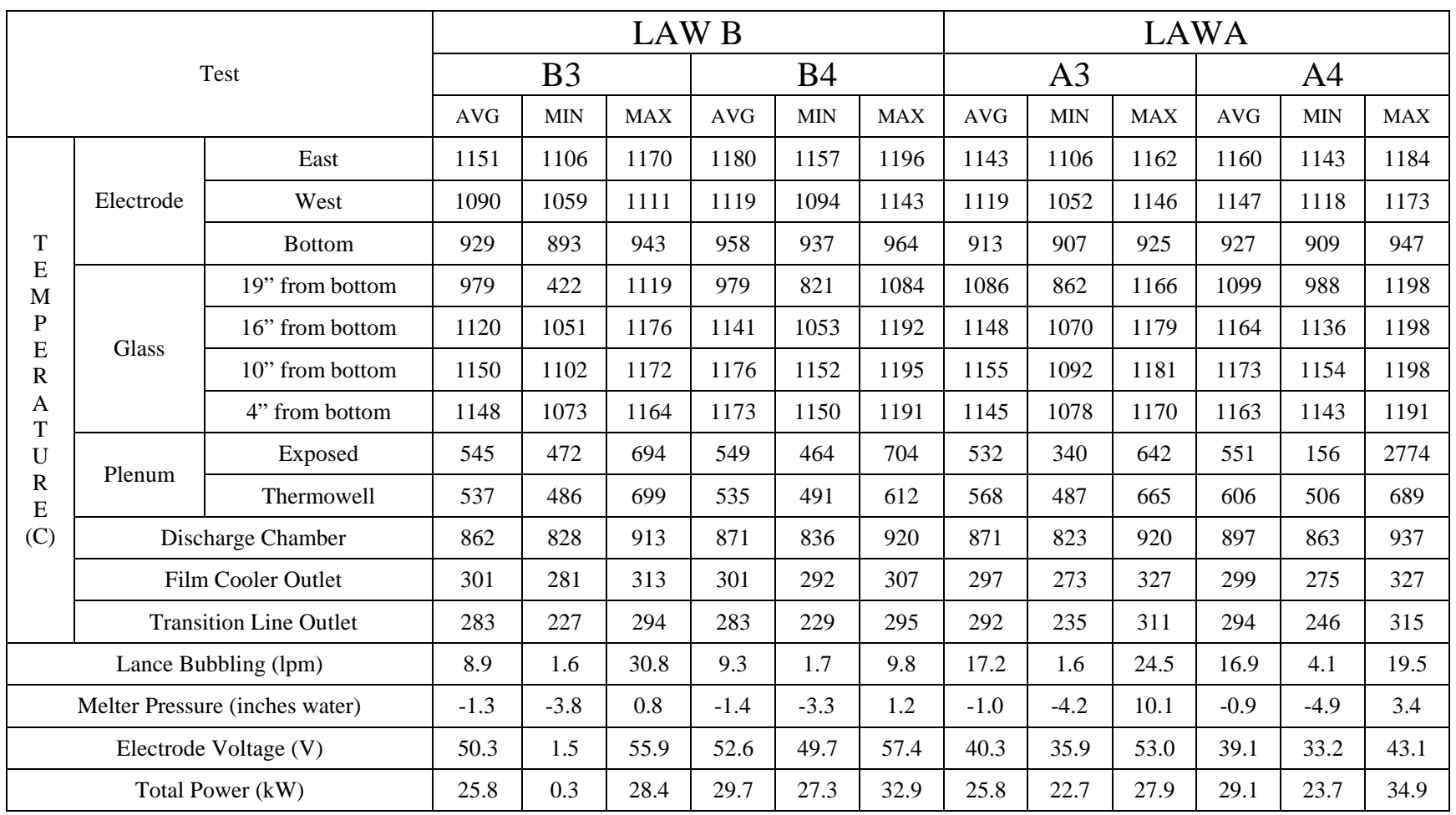


Table 5.1. Listing of LAWB DM100 Glasses Discharged, Masses, and Analysis Performed.

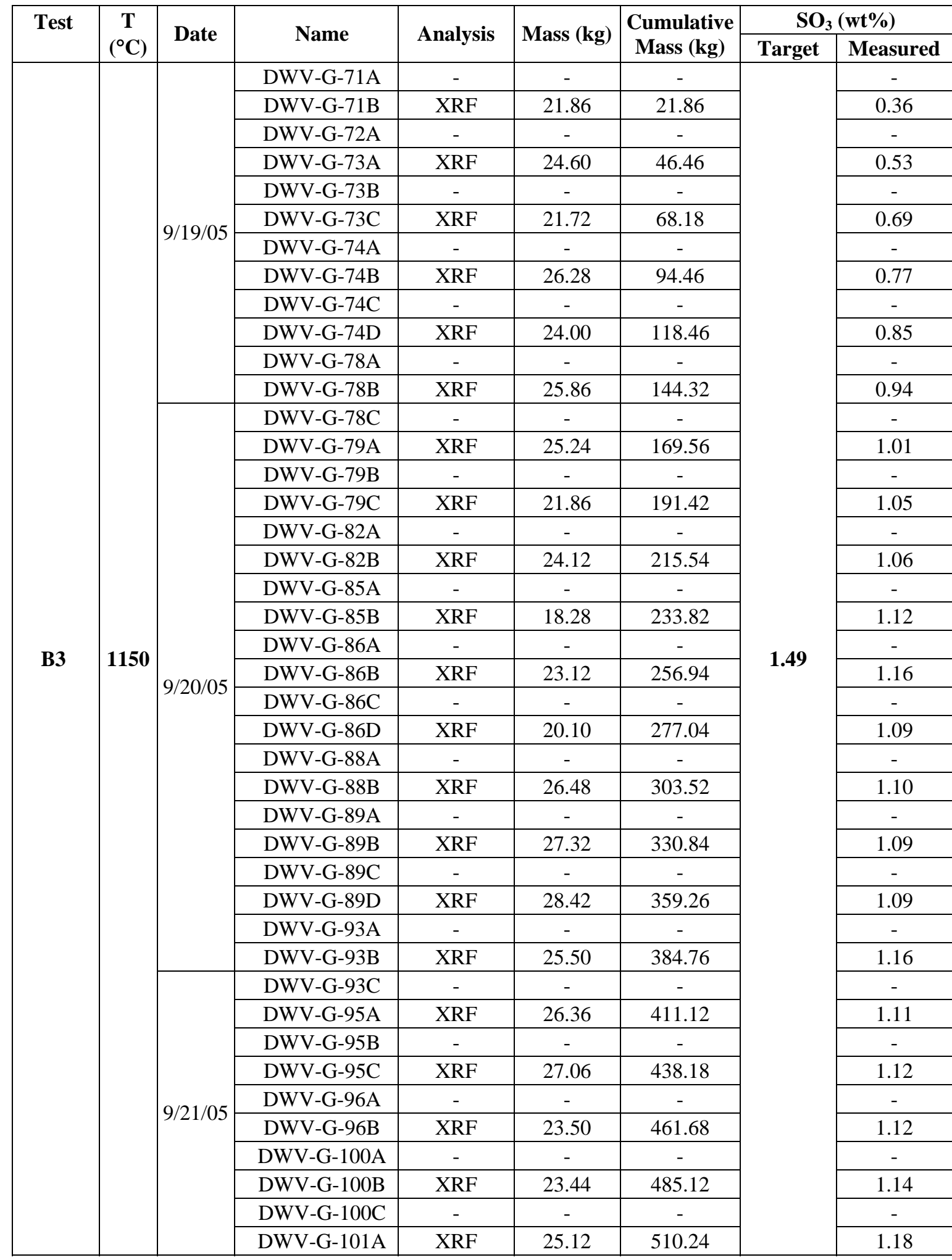

- Empty data field 
Table 5.1. Listing of LAWB DM100 Glasses Discharged, Masses, and Analysis Performed. (continued).

\begin{tabular}{|c|c|c|c|c|c|c|c|c|}
\hline \multirow[t]{2}{*}{ Test } & \multirow{2}{*}{$\begin{array}{c}\mathrm{T} \\
\left({ }^{\circ} \mathrm{C}\right)\end{array}$} & \multirow{2}{*}{ Date } & \multirow{2}{*}{ Name } & \multirow{2}{*}{ Analysis } & \multirow{2}{*}{ Mass (kg) } & \multirow{2}{*}{$\begin{array}{c}\text { Cumulative } \\
\text { Mass (kg) }\end{array}$} & \multicolumn{2}{|c|}{$\mathrm{SO}_{3}(\mathrm{wt} \%)$} \\
\hline & & & & & & & Target & Measured \\
\hline \multirow{25}{*}{ B3 } & \multirow{25}{*}{1150} & \multirow{10}{*}{$9 / 22 / 05$} & DWV-G-101B & - & - & - & \multirow{25}{*}{1.49} & - \\
\hline & & & DWV-G-103A & XRF & 29.14 & 539.38 & & 1.12 \\
\hline & & & DWV-G-103B & - & - & - & & - \\
\hline & & & DWV-G-103C & XRF & 23.94 & 563.32 & & 1.16 \\
\hline & & & DWV-G-107A & - & - & - & & - \\
\hline & & & DWV-G-107B & XRF & 20.84 & 584.16 & & 1.16 \\
\hline & & & DWV-G-107C & - & - & - & & - \\
\hline & & & DWV-G-107D & XRF & 25.86 & 610.02 & & 1.16 \\
\hline & & & DWV-G-109A & - & - & - & & - \\
\hline & & & DWV-G-109B & XRF & 26.92 & 636.94 & & 1.18 \\
\hline & & \multirow{17}{*}{$9 / 22 / 05$} & DWV-G-110A & - & - & - & & - \\
\hline & & & DWV-G-110B & XRF & 25.08 & 662.02 & & 1.19 \\
\hline & & & DWV-G-110C & - & - & - & & - \\
\hline & & & DWV-G-111A & XRF & 23.7 & 685.72 & & 1.19 \\
\hline & & & DWV-G-111B & - & - & - & & - \\
\hline & & & DWV-G-114A & $\mathrm{XRF}$ & 20.20 & 705.92 & & 1.18 \\
\hline & & & DWV-G-116A & - & - & - & & - \\
\hline & & & DWV-G-116B & XRF & 24.76 & 730.68 & & 1.17 \\
\hline & & & DWV-G-117A & - & - & - & & - \\
\hline & & & DWV-G-117B & XRF & 23.24 & 753.92 & & 1.17 \\
\hline & & & DWV-G-117C & - & - & - & & - \\
\hline & & & DWV-G-117D & $\mathrm{XRF}$ & 26.56 & 780.48 & & 1.18 \\
\hline & & & DWV-G-123A & - & - & - & & - \\
\hline & & & DWV-G-123B & XRF & 22.54 & 803.02 & & 1.18 \\
\hline & & & DWV-G-123C & $\begin{array}{c}\text { XRF, DCP, } \\
\text { PCT, VHT, } \\
\text { ORP }\end{array}$ & 16.76 & 819.78 & & 1.19 \\
\hline \multirow{16}{*}{ B4 } & \multirow{16}{*}{1175} & & DWV-G-125A & - & - & - & \multirow{16}{*}{1.59} & - \\
\hline & & & DWV-G-125B & $\mathrm{XRF}$ & 27.76 & 847.54 & & 1.19 \\
\hline & & \multirow{14}{*}{ 9/23/05 } & DWV-G-126A & - & - & - & & - \\
\hline & & & DWV-G-126B & $\mathrm{XRF}$ & 26.48 & 874.02 & & 1.16 \\
\hline & & & DWV-G-127A & - & - & - & & - \\
\hline & & & DWV-G-127B & $\mathrm{XRF}$ & 24.56 & 898.58 & & 1.16 \\
\hline & & & DWV-G-127C & - & - & - & & - \\
\hline & & & DWV-G-129A & XRF & 24.80 & 923.38 & & 1.17 \\
\hline & & & DWV-G-129B & - & - & - & & - \\
\hline & & & DWV-G-129C & $\mathrm{XRF}$ & 26.84 & 950.22 & & 1.18 \\
\hline & & & DWV-G-132A & - & - & - & & - \\
\hline & & & DWV-G-133A & $\mathrm{XRF}$ & 27.98 & 978.20 & & 1.15 \\
\hline & & & DWV-G-133B & - & - & - & & - \\
\hline & & & DWV-G-136A & $\mathrm{XRF}$ & 25.54 & 1003.74 & & 1.18 \\
\hline & & & DWV-G-136B & - & - & - & & - \\
\hline & & & DWV-G-136C & XRF & 26.96 & 1030.70 & & 1.17 \\
\hline
\end{tabular}

- Empty data field; ORP - Sample to be sent to Office of River Protection, DOE 
Table 5.1 Listing of LAWB DM100 Glasses Discharged, Masses, and Analysis Performed. (continued).

\begin{tabular}{|c|c|c|c|c|c|c|c|c|}
\hline \multirow[t]{2}{*}{ Test } & \multirow{2}{*}{$\begin{array}{c}\mathrm{T} \\
\left({ }^{\circ} \mathrm{C}\right) \\
\end{array}$} & \multirow{2}{*}{ Date } & \multirow{2}{*}{ Name } & \multirow{2}{*}{ Analysis } & \multirow{2}{*}{ Mass (kg) } & \multirow{2}{*}{$\begin{array}{c}\text { Cumulative } \\
\text { Mass (kg) }\end{array}$} & \multicolumn{2}{|c|}{$\mathrm{SO}_{3}(\mathrm{wt} \%)$} \\
\hline & & & & & & & Target & Measured \\
\hline \multirow{40}{*}{ B4 } & \multirow{40}{*}{1175} & \multirow{8}{*}{$9 / 23 / 05$} & DWV-G-137A & - & - & - & \multirow{40}{*}{1.59} & - \\
\hline & & & DWV-G-137B & $\mathrm{XRF}$ & 33.08 & 1063.78 & & 1.16 \\
\hline & & & DWV-G-137C & - & - & - & & - \\
\hline & & & DWV-G-141A & XRF & 31.96 & 1095.74 & & 1.17 \\
\hline & & & DWV-G-141B & - & - & - & & - \\
\hline & & & DWV-G-141C & $\mathrm{XRF}$ & 22.68 & 1118.42 & & 1.17 \\
\hline & & & DWV-G-141D & - & - & - & & - \\
\hline & & & DWV-G-142A & XRF & 24.38 & 1142.80 & & 1.19 \\
\hline & & \multirow{23}{*}{$9 / 24 / 05$} & DWV-G-142B & - & - & - & & - \\
\hline & & & DWV-G-142C & XRF & 24.4 & 1167.20 & & 1.17 \\
\hline & & & DWV-G-142D & - & - & - & & - \\
\hline & & & DWV-G-142E & XRF & 25.56 & 1192.76 & & 1.19 \\
\hline & & & DWV-G-143A & - & - & - & & - \\
\hline & & & DWV-G-143B & $\mathrm{XRF}$ & 24.86 & 1217.62 & & 1.16 \\
\hline & & & DWV-G-143C & - & - & - & & - \\
\hline & & & DWV-G-143D & XRF & 26.94 & 1244.56 & & 1.16 \\
\hline & & & DWV-G-148A & - & - & - & & - \\
\hline & & & DWV-G-148B & XRF & 27.6 & 1272.16 & & 1.19 \\
\hline & & & DWV-G-149A & - & - & - & & - \\
\hline & & & DWV-G-149B & XRF & 21.78 & 1293.94 & & 1.17 \\
\hline & & & DWV-G-149C & - & - & - & & - \\
\hline & & & DWV-G-150A & $\mathrm{XRF}$ & 21 & 1314.94 & & 1.18 \\
\hline & & & DWV-G-150B & - & - & - & & - \\
\hline & & & DWV-G-150C & XRF & 23.82 & 1338.76 & & 1.18 \\
\hline & & & DWV-G-151A & - & - & - & & - \\
\hline & & & DWV-G-151B & XRF & 28.98 & 1367.74 & & 1.19 \\
\hline & & & DWV-G-155A & - & - & - & & - \\
\hline & & & DWV-G-155B & XRF & 23.86 & 1391.60 & & 1.20 \\
\hline & & & DWV-G-155C & - & - & - & & - \\
\hline & & & DWV-G-155D & $\mathrm{XRF}$ & 24.52 & 1416.12 & & 1.20 \\
\hline & & & EWV-G-9A & - & - & - & & - \\
\hline & & \multirow{9}{*}{$9 / 25 / 05$} & EWV-G-9B & $\mathrm{XRF}$ & 24.48 & 1440.60 & & 1.18 \\
\hline & & & EWV-G-9C & - & - & - & & - \\
\hline & & & EWV-G-9D & XRF & 25.86 & 1466.46 & & 1.15 \\
\hline & & & EWV-G-9E & - & - & - & & - \\
\hline & & & EWV-G-10A & XRF & 24.34 & 1490.80 & & 1.17 \\
\hline & & & EWV-G-10B & - & - & - & & - \\
\hline & & & EWV-G-10C & XRF, ORP & 23.22 & 1514.02 & & 1.18 \\
\hline & & & EWV-G-10D & - & - & - & & - \\
\hline & & & EWV-G-11A & $\begin{array}{c}\text { XRF, DCP, } \\
\text { ORP }\end{array}$ & 24.78 & 1538.80 & & 1.17 \\
\hline
\end{tabular}

ORP-Sample to be sent to Office of River Protection, DOE

- Empty data field 
Table 5.2. Listing of LAWA DM100 Glasses Discharged, Masses, and Analysis Performed.

\begin{tabular}{|c|c|c|c|c|c|c|c|c|}
\hline \multirow{2}{*}{ Test } & \multirow{2}{*}{$\mathbf{T}\left({ }^{\circ} \mathbf{C}\right)$} & \multirow{2}{*}{ Date } & \multirow{2}{*}{ Sample Name } & \multirow{2}{*}{ Analysis } & \multirow{2}{*}{$\begin{array}{c}\text { Mass } \\
\text { (kg) }\end{array}$} & \multirow{2}{*}{$\begin{array}{l}\text { Cumulative } \\
\text { Mass (kg) }\end{array}$} & \multicolumn{2}{|c|}{$\mathrm{SO}_{3}(\mathrm{wt} \%)$} \\
\hline & & & & & & & Target & Measured \\
\hline \multirow{42}{*}{ A3 } & \multirow{42}{*}{1150} & \multirow{12}{*}{$10 / 05 / 05$} & EWV-G-32A & - & - & - & \multirow{42}{*}{0.95} & - \\
\hline & & & EWV-G-32B & XRF & 27.32 & 27.32 & & 1.08 \\
\hline & & & EWV-G-33A & - & - & - & & - \\
\hline & & & EWV-G-33B & XRF & 16.46 & 43.78 & & 1.09 \\
\hline & & & EWV-G-34A & - & - & - & & - \\
\hline & & & EWV-G-35A & XRF & 30.46 & 74.24 & & 1.00 \\
\hline & & & EWV-G-35B & - & - & - & & - \\
\hline & & & EWV-G-35C & XRF & 28.62 & 102.86 & & 0.92 \\
\hline & & & EWV-G-37A & - & - & - & & - \\
\hline & & & EWV-G-37B & XRF & 30.32 & 133.18 & & 0.92 \\
\hline & & & EWV-G-37C & - & - & - & & - \\
\hline & & & EWV-G-40A & XRF & 16.64 & 149.82 & & 0.91 \\
\hline & & \multirow{19}{*}{$10 / 06 / 05$} & EWV-G-40B & - & - & - & & - \\
\hline & & & EWV-G-41A & XRF & 19.62 & 169.44 & & 0.86 \\
\hline & & & EWV-G-43A & - & - & - & & - \\
\hline & & & EWV-G-43B & XRF & 25.46 & 194.90 & & 0.84 \\
\hline & & & EWV-G-45A & - & - & - & & - \\
\hline & & & EWV-G-46A & XRF & 20.26 & 215.16 & & 0.81 \\
\hline & & & EWV-G-46B & - & - & - & & - \\
\hline & & & EWV-G-49A & XRF & 20.30 & 235.46 & & 0.82 \\
\hline & & & EWV-G-49B & - & - & - & & - \\
\hline & & & EWV-G-49C & XRF & 19.04 & 254.50 & & 0.81 \\
\hline & & & EWV-G-51A & - & - & - & & - \\
\hline & & & EWV-G-51B & XRF & 23.54 & 278.04 & & 0.80 \\
\hline & & & EWV-G-52A & - & - & - & & - \\
\hline & & & EWV-G-53A & XRF & 28.10 & 306.14 & & 0.79 \\
\hline & & & EWV-G-53B & - & - & - & & - \\
\hline & & & EWV-G-53C & XRF & 18.18 & 324.32 & & 0.82 \\
\hline & & & EWV-G-57A & - & - & - & & - \\
\hline & & & EWV-G-57B & XRF & 40.00 & 364.32 & & 0.77 \\
\hline & & & EWV-G-57C & - & - & - & & - \\
\hline & & \multirow{11}{*}{$10 / 07 / 05$} & EWV-G-58A & XRF & 20.78 & 385.10 & & 0.80 \\
\hline & & & EWV-G-60A & - & - & - & & - \\
\hline & & & EWV-G-60B & - & - & - & & - \\
\hline & & & EWV-G-60C & XRF & 38.56 & 423.66 & & 0.80 \\
\hline & & & EWV-G-61A & - & - & - & & - \\
\hline & & & EWV-G-65A & - & - & - & & - \\
\hline & & & EWV-G-65B & XRF & 24.92 & 448.58 & & 0.80 \\
\hline & & & EWV-G-65C & - & - & - & & - \\
\hline & & & EWV-G-66A & XRF & 20.02 & 468.60 & & 0.77 \\
\hline & & & EWV-G-66B & - & - & - & & - \\
\hline & & & EWV-G-66C & XRF & 19.32 & 487.92 & & 0.78 \\
\hline
\end{tabular}

- Empty data field 
Table 5.2. Listing of LAWA DM100 Glasses Discharged, Masses, and Analysis Performed, (continued).

\begin{tabular}{|c|c|c|c|c|c|c|c|c|}
\hline \multirow[t]{2}{*}{ Test } & \multirow{2}{*}{$\mathbf{T}\left({ }^{\circ} \mathrm{C}\right)$} & \multirow{2}{*}{ Date } & \multirow{2}{*}{ Sample Name } & \multirow{2}{*}{ Analysis } & \multirow{2}{*}{$\begin{array}{c}\text { Mass } \\
\text { (kg) }\end{array}$} & \multirow{2}{*}{$\begin{array}{c}\text { Cumulative } \\
\text { Mass (kg) }\end{array}$} & \multicolumn{2}{|c|}{$\mathrm{SO}_{3}(\mathrm{wt} \%)$} \\
\hline & & & & & & & Target & Measured \\
\hline \multirow{26}{*}{ A3 } & \multirow{26}{*}{1150} & \multirow{9}{*}{ 10/7/05 } & EWV-G-67A & - & - & - & \multirow{26}{*}{0.95} & - \\
\hline & & & EWV-G-67B & XRF & 29.92 & 517.84 & & 0.79 \\
\hline & & & EWV-G-69A & - & - & - & & - \\
\hline & & & EWV-G-69B & XRF & 23.16 & 541.00 & & 0.79 \\
\hline & & & EWV-G-69C & - & - & - & & - \\
\hline & & & EWV-G-72A & $\mathrm{XRF}$ & 24.68 & 565.68 & & 0.79 \\
\hline & & & EWV-G-72B & - & - & - & & - \\
\hline & & & EWV-G-72C & XRF & 23.76 & 589.44 & & 0.77 \\
\hline & & & EWV-G-75A & - & - & - & & - \\
\hline & & \multirow{20}{*}{ 10/8/05 } & EWV-G-75B & XRF & 23.86 & 613.30 & & 0.79 \\
\hline & & & EWV-G-76A & - & - & - & & - \\
\hline & & & EWV-G-76B & XRF & 19.36 & 632.66 & & 0.77 \\
\hline & & & EWV-G-76C & - & - & - & & - \\
\hline & & & EWV-G-77A & $\mathrm{XRF}$ & 19.38 & 652.04 & & 0.81 \\
\hline & & & EWV-G-78A & - & - & - & & - \\
\hline & & & EWV-G-78B & $\mathrm{XRF}$ & 22.30 & 674.34 & & 0.75 \\
\hline & & & EWV-G-79A & - & - & - & & - \\
\hline & & & EWV-G-79B & XRF & 18.24 & 692.58 & & 0.79 \\
\hline & & & EWV-G-83A & - & - & - & & - \\
\hline & & & EWV-G-83B & XRF & 21.58 & 714.16 & & 0.79 \\
\hline & & & EWV-G-84A & - & - & - & & - \\
\hline & & & EWV-G-84B & XRF & 23.76 & 737.92 & & 0.79 \\
\hline & & & EWV-G-85A & - & - & - & & - \\
\hline & & & EWV-G-85B & $\mathrm{XRF}$ & 24.2 & 762.12 & & 0.78 \\
\hline & & & EWV-G-89A & - & - & - & & - \\
\hline & & & EWV-G-89B & $\begin{array}{c}\text { XRF, DCP, } \\
\text { PCT, VHT, } \\
\text { ORP }\end{array}$ & 25.08 & 787.20 & & 0.79 \\
\hline \multirow{16}{*}{ A4 } & \multirow{16}{*}{1175} & & EWV-G-93A & - & - & - & \multirow{16}{*}{1.05} & - \\
\hline & & & EWV-G-93B & XRF & 25.76 & 812.96 & & 0.79 \\
\hline & & & EWV-G-94A & - & - & - & & - \\
\hline & & \multirow{13}{*}{$10 / 9 / 05$} & EWV-G-94B & XRF & 20.46 & 833.42 & & 0.81 \\
\hline & & & EWV-G-95A & - & - & - & & - \\
\hline & & & EWV-G-95B & $\mathrm{XRF}$ & 20.54 & 853.96 & & 0.83 \\
\hline & & & EWV-G-95C & - & - & - & & - \\
\hline & & & EWV-G-96A & XRF & 25.46 & 879.42 & & 0.84 \\
\hline & & & EWV-G-96B & - & - & - & & - \\
\hline & & & EWV-G-100A & XRF & 20.78 & 900.20 & & 0.81 \\
\hline & & & EWV-G-100B & - & - & - & & - \\
\hline & & & EWV-G-101A & XRF & 25.12 & 925.32 & & 0.85 \\
\hline & & & EWV-G-101B & - & - & - & & - \\
\hline & & & EWV-G-101C & $\mathrm{XRF}$ & 24.82 & 950.14 & & 0.83 \\
\hline & & & EWV-G-103A & - & - & - & & - \\
\hline & & & EWV-G-103B & XRF & 22.52 & 972.66 & & 0.86 \\
\hline
\end{tabular}

- Empty data field; ORP-Sample to be sent to Office of River Protection, DOE 
Table 5.2. Listing of LAWA DM100 Glasses Discharged, Masses, and Analysis Performed, (continued).

\begin{tabular}{|c|c|c|c|c|c|c|c|c|}
\hline \multirow{2}{*}{ Test } & \multirow{2}{*}{$\mathbf{T}\left({ }^{\circ} \mathrm{C}\right)$} & \multirow{2}{*}{ Date } & \multirow{2}{*}{ Sample Name } & \multirow{2}{*}{ Analysis } & \multirow{2}{*}{$\begin{array}{c}\text { Mass } \\
\text { (kg) }\end{array}$} & \multirow{2}{*}{$\begin{array}{c}\text { Cumulative } \\
\text { Mass (kg) }\end{array}$} & \multicolumn{2}{|c|}{$\mathrm{SO}_{3}(\mathrm{wt} \%)$} \\
\hline & & & & & & & Target & Measured \\
\hline \multirow{40}{*}{ A4 } & \multirow{40}{*}{1175} & \multirow{15}{*}{$10 / 9 / 05$} & EWV-G-103C & - & - & - & \multirow{40}{*}{1.05} & - \\
\hline & & & EWV-G-104A & $\mathrm{XRF}$ & 17.94 & 990.60 & & 0.82 \\
\hline & & & EWV-G-104B & - & - & - & & - \\
\hline & & & EWV-G-104C & XRF & 22.88 & 1013.48 & & 0.83 \\
\hline & & & EWV-G-105A & - & - & - & & - \\
\hline & & & EWV-G-107A & XRF & 21.14 & 1034.62 & & 0.92 \\
\hline & & & EWV-G-107B & - & - & - & & - \\
\hline & & & EWV-G-107C & $\mathrm{XRF}$ & 15.80 & 1050.42 & & 0.82 \\
\hline & & & EWV-G-108A & - & - & - & & - \\
\hline & & & EWV-G-108B & XRF & 31.54 & 1081.96 & & 0.85 \\
\hline & & & EWV-G-109A & - & - & - & & - \\
\hline & & & EWV-G-113A & XRF & 29.04 & 1111.00 & & 0.82 \\
\hline & & & EWV-G-113B & - & - & - & & - \\
\hline & & & EWV-G-115A & $\mathrm{XRF}$ & 20.32 & 1131.32 & & 0.83 \\
\hline & & & EWV-G-115B & - & - & - & & - \\
\hline & & \multirow{25}{*}{$10 / 10 / 05$} & EWV-G-116A & XRF & 16.22 & 1147.54 & & 0.85 \\
\hline & & & EWV-G-116B & - & - & - & & - \\
\hline & & & EWV-G-117A & XRF & 25.42 & 1172.96 & & 0.83 \\
\hline & & & EWV-G-118A & - & - & - & & - \\
\hline & & & EWV-G-118B & XRF & 33.84 & 1206.80 & & 0.84 \\
\hline & & & EWV-G-120A & - & - & - & & - \\
\hline & & & EWV-G-120B & $\mathrm{XRF}$ & 17.00 & 1223.80 & & 0.81 \\
\hline & & & EWV-G-123A & - & - & - & & - \\
\hline & & & EWV-G-123B & XRF & 22.34 & 1246.14 & & 0.86 \\
\hline & & & EWV-G-123C & - & - & - & & - \\
\hline & & & EWV-G-124A & $\mathrm{XRF}$ & 15.72 & 1261.86 & & 0.82 \\
\hline & & & EWV-G-124B & - & - & - & & - \\
\hline & & & EWV-G-124C & $\mathrm{XRF}$ & 17.74 & 1279.60 & & 0.82 \\
\hline & & & EWV-G-124D & - & - & - & & - \\
\hline & & & EWV-G-125A & XRF & 17.80 & 1297.40 & & 0.83 \\
\hline & & & EWV-G-125B & - & - & - & & - \\
\hline & & & EWV-G-127A & $\mathrm{XRF}$ & 30.12 & 1327.52 & & 0.85 \\
\hline & & & EWV-G-127B & - & - & - & & - \\
\hline & & & EWV-G-129A & XRF & 21.82 & 1349.34 & & 0.82 \\
\hline & & & EWV-G-129B & - & - & - & & - \\
\hline & & & EWV-G-129C & XRF & 15.82 & 1365.16 & & 0.84 \\
\hline & & & EWV-G-132A & - & - & - & & - \\
\hline & & & EWV-G-132B & $\mathrm{XRF}$ & 23.70 & 1388.86 & & 0.81 \\
\hline & & & EWV-G-132C & - & - & - & & - \\
\hline & & & EWV-G-133A & $\mathrm{XRF}$ & 25.44 & 1414.30 & & 0.86 \\
\hline
\end{tabular}

- Empty data field 
Table 5.2. Listing of LAWA DM100 Glasses Discharged, Masses, and Analysis Performed, (continued).

\begin{tabular}{|c|c|c|c|c|c|c|c|c|}
\hline \multirow{2}{*}{ Test } & \multirow{2}{*}{$\mathbf{T}\left({ }^{\circ} \mathrm{C}\right)$} & \multirow{2}{*}{ Date } & \multirow{2}{*}{ Sample Name } & \multirow{2}{*}{ Analysis } & \multirow{2}{*}{$\begin{array}{c}\text { Mass } \\
\text { (kg) }\end{array}$} & \multirow{2}{*}{$\begin{array}{c}\text { Cumulative } \\
\text { Mass (kg) }\end{array}$} & \multicolumn{2}{|c|}{$\mathrm{SO}_{3}(\mathrm{wt} \%)$} \\
\hline & & & & & & & Target & Measured \\
\hline \multirow{10}{*}{ A4 } & \multirow{10}{*}{1175} & \multirow{10}{*}{$10 / 11 / 05$} & EWV-G-133B & - & - & - & \multirow{10}{*}{1.05} & - \\
\hline & & & EWV-G-133C & XRF & 33.74 & 1448.04 & & 0.83 \\
\hline & & & EWV-G-135A & - & - & - & & - \\
\hline & & & EWV-G-135B & XRF & 19.44 & 1467.48 & & 0.86 \\
\hline & & & EWV-G-136A & - & - & - & & - \\
\hline & & & EWV-G-136B & XRF & 22.74 & 1490.22 & & 0.86 \\
\hline & & & EWV-G-138A & - & - & - & & - \\
\hline & & & EWV-G-141A & XRF, ORP & 23.20 & 1513.42 & & 0.87 \\
\hline & & & EWV-G-141B & - & - & - & & - \\
\hline & & & EWV-G-143A & $\begin{array}{c}\text { XRF, DCP, } \\
\text { ORP }\end{array}$ & 12.40 & 1525.82 & & 0.87 \\
\hline
\end{tabular}

ORP-Sample to be sent to Office of River Protection, DOE

- Empty data field 
Table 5.3. XRF Analyzed Composition for LAWB DM100 Discharged Glass Samples (wt\%).

\begin{tabular}{|c|c|c|c|c|c|c|c|c|c|c|c|c|c|c|c|c|}
\hline Test & \multicolumn{16}{|c|}{ B3 } \\
\hline Glass (kg) & -- & 21.86 & 46.46 & 68.18 & 94.46 & 118.46 & 144.32 & 169.56 & 191.42 & 215.54 & 233.82 & 256.94 & 277.04 & 303.52 & 330.84 & 359.26 \\
\hline Element & Target & $\begin{array}{l}\text { DWV- } \\
\text { G-71B }\end{array}$ & $\begin{array}{l}\text { DWV- } \\
\text { G-73A }\end{array}$ & $\begin{array}{l}\text { DWV- } \\
\text { G-73C }\end{array}$ & $\begin{array}{l}\text { DWV- } \\
\text { G-74B }\end{array}$ & $\begin{array}{l}\text { DWV- } \\
\text { G-74D }\end{array}$ & $\begin{array}{l}\text { DWV- } \\
\text { G-78B }\end{array}$ & $\begin{array}{l}\text { DWV- } \\
\text { G-79A }\end{array}$ & $\begin{array}{l}\text { DWV- } \\
\text { G-79C }\end{array}$ & $\begin{array}{l}\text { DWV- } \\
\text { G-82B }\end{array}$ & $\begin{array}{l}\text { DWV- } \\
\text { G-85B }\end{array}$ & $\begin{array}{l}\text { DWV- } \\
\text { G-86B }\end{array}$ & $\begin{array}{l}\text { DWV- } \\
\text { G-86D }\end{array}$ & $\begin{array}{l}\text { DWV- } \\
\text { G-88B }\end{array}$ & $\begin{array}{l}\text { DWV- } \\
\text { G-89B }\end{array}$ & $\begin{array}{l}\text { DWV- } \\
\text { G-89D }\end{array}$ \\
\hline $\mathrm{Al}_{2} \mathrm{O}_{3}$ & 10.06 & 6.47 & 6.95 & 7.40 & 7.73 & 7.94 & 7.91 & 8.69 & 8.54 & 8.63 & 8.83 & 8.78 & 9.14 & 9.30 & 9.36 & 9.30 \\
\hline $\mathrm{B}_{2} \mathrm{O}_{3} *$ & 10.91 & 9.96 & 10.14 & 10.27 & 10.39 & 10.48 & 10.57 & 10.63 & 10.68 & 10.72 & 10.75 & 10.77 & 10.79 & 10.82 & 10.83 & 10.85 \\
\hline $\mathrm{CaO}$ & 10.11 & 2.27 & 3.53 & 4.68 & 5.48 & 5.73 & 6.15 & 6.73 & 6.97 & 7.35 & 7.74 & 8.11 & 7.99 & 8.12 & 8.36 & 8.57 \\
\hline $\mathrm{Cl}$ & 0.01 & 0.32 & 0.26 & 0.20 & 0.15 & 0.13 & 0.11 & 0.08 & 0.07 & 0.06 & 0.05 & 0.04 & 0.04 & 0.03 & 0.03 & 0.03 \\
\hline $\mathrm{Cr}_{2} \mathrm{O}_{3}$ & 0.11 & 0.26 & 0.28 & 0.26 & 0.27 & 0.26 & 0.24 & 0.23 & 0.23 & 0.23 & 0.23 & 0.23 & 0.21 & 0.21 & 0.21 & 0.21 \\
\hline $\mathrm{F}$ & 0.07 & NA & NA & NA & NA & NA & NA & NA & NA & NA & NA & NA & NA & NA & NA & NA \\
\hline $\mathrm{Fe}_{2} \mathrm{O}_{3}$ & 1.14 & 5.05 & 4.84 & 4.10 & 3.81 & 3.48 & 3.15 & 2.62 & 2.47 & 2.53 & 2.17 & 2.19 & 1.99 & 1.83 & 1.74 & 1.69 \\
\hline I & 0.10 & $<0.01$ & 0.01 & 0.01 & 0.02 & 0.03 & 0.02 & 0.02 & 0.02 & 0.03 & 0.03 & 0.03 & 0.03 & 0.02 & 0.03 & 0.03 \\
\hline $\mathrm{K}_{2} \mathrm{O}$ & 0.40 & 4.12 & 3.68 & 3.08 & 2.75 & 2.46 & 2.24 & 1.87 & 1.71 & 1.64 & 1.39 & 1.39 & 1.22 & 1.09 & 1.03 & 0.98 \\
\hline $\mathrm{Li}_{2} \mathrm{O}^{*}$ & 3.52 & 0.59 & 1.13 & 1.52 & 1.92 & 2.21 & 2.46 & 2.66 & 2.80 & 2.93 & 3.01 & 3.10 & 3.17 & 3.24 & 3.29 & 3.34 \\
\hline $\mathrm{MgO}$ & 1.14 & 1.43 & 1.42 & 1.42 & 1.36 & 1.30 & 1.30 & 1.24 & 1.28 & 1.28 & 1.29 & 1.17 & 1.23 & 1.24 & 1.16 & 1.20 \\
\hline $\mathrm{Na}_{2} \mathrm{O}$ & 9.96 & 18.30 & 16.08 & 15.02 & 14.18 & 14.22 & 13.62 & 12.64 & 12.74 & 12.26 & 12.32 & 11.23 & 11.75 & 12.06 & 11.82 & 11.18 \\
\hline $\mathrm{P}_{2} \mathrm{O}_{5}$ & 0.03 & 0.18 & 0.16 & 0.14 & 0.13 & 0.13 & 0.12 & 0.12 & 0.11 & 0.10 & 0.10 & 0.10 & 0.10 & 0.09 & 0.09 & 0.08 \\
\hline $\mathrm{SiO}_{2}$ & 42.73 & 43.93 & 43.19 & 43.33 & 42.80 & 42.71 & 43.22 & 43.70 & 43.58 & 42.93 & 42.93 & 43.20 & 43.20 & 42.81 & 42.74 & 43.12 \\
\hline $\mathrm{SO}_{3}$ & 1.50 & 0.36 & 0.51 & 0.67 & 0.74 & 0.82 & 0.89 & 0.96 & 1.00 & 1.01 & 1.06 & 1.09 & 1.08 & 1.09 & 1.08 & 1.07 \\
\hline $\mathrm{TiO}_{2}$ & $\S$ & 1.41 & 1.32 & 1.10 & 0.99 & 0.89 & 0.78 & 0.64 & 0.59 & 0.57 & 0.50 & 0.49 & 0.46 & 0.41 & 0.39 & 0.34 \\
\hline $\mathrm{V}_{2} \mathrm{O}_{5}$ & 1.23 & 0.06 & 0.27 & 0.48 & 0.63 & 0.70 & 0.78 & 0.88 & 0.93 & 1.00 & 1.07 & 1.13 & 1.12 & 1.15 & 1.20 & 1.21 \\
\hline $\mathrm{ZnO}$ & 3.51 & 2.81 & 3.18 & 3.24 & 3.37 & 3.27 & 3.16 & 3.10 & 3.06 & 3.25 & 3.12 & 3.29 & 3.10 & 3.08 & 3.17 & 3.21 \\
\hline $\mathrm{ZrO}_{2}$ & 3.51 & 2.47 & 3.05 & 3.07 & 3.30 & 3.24 & 3.25 & 3.19 & 3.22 & 3.48 & 3.43 & 3.64 & 3.39 & 3.39 & 3.47 & 3.57 \\
\hline Sum & 100.00 & 100.00 & 100.00 & 100.00 & 100.00 & 100.00 & 100.00 & 100.00 & 100.00 & 100.00 & 100.00 & 100.00 & 100.00 & 100.00 & 100.00 & 100.00 \\
\hline
\end{tabular}

* - Target values calculated based on simple well-stirred tank model

NA - Not analyzed by XRF; NC - Not calculated

$\S-$ Not a target constituent 
Table 5.3. XRF Analyzed Composition for LAWB DM100 Discharged Glass Samples (wt\%) (continued).

\begin{tabular}{|c|c|c|c|c|c|c|c|c|c|c|c|c|c|c|c|c|}
\hline Test & \multicolumn{16}{|c|}{ B3 } \\
\hline Glass (kg) & - & 384.76 & 411.12 & 438.18 & 461.68 & 485.12 & 510.24 & 539.38 & 563.32 & 584.16 & 610.02 & 636.94 & 662.02 & 685.72 & 705.92 & 730.68 \\
\hline Element & Target & $\begin{array}{l}\text { DWV- } \\
\text { G-93B }\end{array}$ & $\begin{array}{l}\text { DWV- } \\
\text { G-95A }\end{array}$ & $\begin{array}{l}\text { DWV- } \\
\text { G-95C }\end{array}$ & $\begin{array}{l}\text { DWV- } \\
\text { G-96B }\end{array}$ & $\begin{array}{r}\text { DWV- } \\
\text { G-100B }\end{array}$ & $\begin{array}{r}\text { DWV- } \\
\text { G-101A }\end{array}$ & $\begin{array}{r}\text { DWV- } \\
\text { G-103A }\end{array}$ & $\begin{array}{r}\text { DWV- } \\
\text { G-103C }\end{array}$ & $\begin{array}{r}\text { DWV- } \\
\text { G-107B }\end{array}$ & $\begin{array}{r}\text { DWV- } \\
\text { G-107D }\end{array}$ & $\begin{array}{r}\text { DWV- } \\
\text { G-109B }\end{array}$ & $\begin{array}{r}\text { DWV- } \\
\text { G-110B }\end{array}$ & $\begin{array}{r}\text { DWV- } \\
\text { G-111A }\end{array}$ & \begin{tabular}{|r|} 
DWV- \\
G-114A
\end{tabular} & $\begin{array}{r}\text { DWV- } \\
\text { G-116B }\end{array}$ \\
\hline $\mathrm{Al}_{2} \mathrm{O}_{3}$ & 10.06 & 9.39 & 9.39 & 9.42 & 9.44 & 9.45 & 9.63 & $\begin{array}{r}9.58 \\
\end{array}$ & 9.64 & $\begin{array}{r}9.58 \\
\end{array}$ & 9.50 & 9.56 & 9.59 & 9.59 & $\begin{array}{r}9.44 \\
\end{array}$ & 9.55 \\
\hline $\mathrm{B}_{2} \mathrm{O}_{3}{ }^{*}$ & 10.91 & 10.86 & 10.87 & 10.88 & 10.88 & 10.89 & 10.89 & 10.89 & 10.90 & 10.90 & 10.90 & 10.90 & 10.90 & 10.90 & 10.90 & 10.90 \\
\hline $\mathrm{CaO}$ & 10.11 & 8.55 & 8.73 & 8.85 & 8.99 & 9.03 & 9.10 & 9.29 & 9.30 & 9.33 & 9.31 & 9.23 & 9.23 & 9.18 & 9.47 & 9.61 \\
\hline $\mathrm{Cl}$ & 0.01 & 0.02 & 0.02 & 0.02 & 0.02 & 0.02 & 0.02 & 0.01 & 0.02 & 0.02 & 0.02 & 0.01 & 0.01 & 0.01 & 0.01 & 0.01 \\
\hline $\mathrm{Cr}_{2} \mathrm{O}_{3}$ & 0.11 & 0.20 & 0.20 & 0.20 & 0.21 & 0.21 & 0.21 & 0.21 & 0.21 & 0.21 & 0.21 & 0.20 & 0.20 & 0.19 & 0.20 & 0.21 \\
\hline$F$ & 0.07 & NA & NA & NA & NA & NA & NA & NA & NA & NA & NA & NA & NA & NA & NA & NA \\
\hline $\mathrm{Fe}_{2} \mathrm{O}_{3}$ & 1.14 & 1.58 & 1.54 & 1.50 & 1.48 & 1.46 & 1.43 & 1.42 & 1.41 & 1.38 & 1.34 & 1.32 & 1.28 & 1.26 & 1.29 & 1.34 \\
\hline $\mathrm{I}$ & 0.10 & 0.03 & 0.03 & 0.03 & 0.03 & 0.03 & 0.03 & 0.03 & 0.03 & 0.03 & 0.03 & 0.03 & 0.03 & 0.03 & 0.02 & 0.02 \\
\hline $\mathrm{K}_{2} \mathrm{O}$ & 0.40 & 0.92 & 0.88 & 0.84 & 0.79 & 0.78 & 0.73 & 0.70 & 0.69 & 0.69 & 0.68 & 0.66 & 0.65 & 0.64 & 0.62 & 0.61 \\
\hline $\mathrm{Li}_{2} \mathrm{O}^{*}$ & 3.52 & 3.37 & 3.40 & 3.42 & 3.44 & 3.45 & 3.47 & 3.48 & 3.48 & 3.49 & 3.49 & 3.50 & 3.50 & 3.50 & 3.51 & 3.51 \\
\hline $\mathrm{MgO}$ & 1.14 & 1.12 & 1.17 & 1.17 & 1.13 & 1.11 & 1.16 & 1.11 & 1.14 & 1.10 & 1.09 & 1.14 & 1.12 & 1.14 & 1.13 & 1.18 \\
\hline $\mathrm{Na}_{2} \mathrm{O}$ & 9.96 & 11.00 & 11.03 & 10.91 & 10.49 & 10.87 & 11.02 & 10.58 & 10.50 & 10.43 & 10.54 & 10.63 & 10.40 & 10.67 & 10.53 & 10.28 \\
\hline $\mathrm{P}_{2} \mathrm{O}_{5}$ & 0.03 & 0.09 & 0.08 & 0.09 & 0.08 & 0.08 & 0.08 & 0.09 & 0.08 & 0.08 & 0.08 & 0.08 & 0.08 & 0.08 & 0.08 & 0.08 \\
\hline $\mathrm{SiO}_{2}$ & 42.73 & 43.65 & 43.28 & 43.26 & 43.48 & 43.17 & 42.70 & 42.95 & 42.89 & 43.00 & 43.10 & 43.32 & 43.69 & 43.60 & 43.29 & 42.75 \\
\hline $\mathrm{SO}_{3}$ & 1.50 & 1.14 & 1.10 & 1.11 & 1.11 & 1.12 & 1.16 & 1.10 & 1.14 & 1.14 & 1.14 & 1.16 & 1.17 & 1.17 & 1.16 & 1.15 \\
\hline $\mathrm{TiO}_{2}$ & $\S$ & 0.33 & 0.31 & 0.30 & 0.30 & 0.29 & 0.28 & 0.27 & 0.27 & 0.27 & 0.24 & 0.23 & 0.22 & 0.23 & 0.24 & 0.24 \\
\hline $\mathrm{V}_{2} \mathrm{O}_{5}$ & 1.23 & 1.22 & 1.25 & 1.28 & 1.29 & 1.32 & 1.35 & 1.38 & 1.38 & 1.37 & 1.37 & 1.34 & 1.35 & 1.32 & 1.37 & 1.41 \\
\hline $\mathrm{ZnO}$ & 3.51 & 3.11 & 3.21 & 3.20 & 3.22 & 3.15 & 3.14 & 3.18 & 3.21 & 3.28 & 3.26 & 3.17 & 3.14 & 3.12 & 3.18 & 3.36 \\
\hline $\mathrm{ZrO}_{2}$ & 3.51 & 3.43 & 3.51 & 3.53 & 3.63 & 3.60 & 3.61 & 3.72 & 3.72 & 3.71 & 3.71 & 3.53 & 3.45 & 3.38 & 3.56 & 3.78 \\
\hline Sum & 100.00 & 100.00 & 100.00 & 100.00 & 100.00 & 100.00 & 100.00 & 100.00 & 100.00 & 100.00 & 100.00 & 100.00 & 100.00 & 100.00 & 100.00 & 100.00 \\
\hline
\end{tabular}

* Target values calculated based on simple well-stirred tank model

NA - Not analyzed by XRF; NC - Not calculated

$\S$ Not a target constituent 
Table 5.3. XRF Analyzed Composition for LAWB DM100 Discharged Glass Samples (wt\%) (continued).

\begin{tabular}{|c|c|c|c|c|c|c|c|c|c|c|c|c|c|c|c|c|}
\hline Test & \multicolumn{7}{|c|}{ B3 } & \multicolumn{9}{|c|}{ B4 } \\
\hline Glass (kg) & - & 753.92 & 780.48 & 803.02 & 819.78 & 384-8 & $20 \mathrm{~kg}$ & - & 847.54 & 874.02 & 898.58 & 923.38 & 950.22 & 978.2 & \begin{tabular}{|l|}
1003.74 \\
\end{tabular} & 1030.7 \\
\hline Element & Target & $\begin{array}{c}\text { DWV- } \\
\text { G-117B }\end{array}$ & $\begin{array}{c}\text { DWV- } \\
\text { G-117D }\end{array}$ & $\begin{array}{c}\text { DWV- } \\
\text { G-123B }\end{array}$ & $\begin{array}{c}\text { DWV- } \\
\text { G-123C }\end{array}$ & Avg. & \%Dev. & Target & $\begin{array}{r}\text { DWV- } \\
\text { G-125B }\end{array}$ & $\begin{array}{r}\text { DWV- } \\
\text { G-126B }\end{array}$ & $\begin{array}{r}\text { DWV- } \\
\text { G-127B }\end{array}$ & $\begin{array}{r}\text { DWV- } \\
\text { G-129A }\end{array}$ & \begin{tabular}{|r|} 
DWV- \\
G-129C
\end{tabular} & \begin{tabular}{|r|} 
DWV- \\
G-133A \\
\end{tabular} & \begin{tabular}{|r|} 
DWV- \\
G-136A
\end{tabular} & $\begin{array}{r}\text { DWV- } \\
\text { G-136C }\end{array}$ \\
\hline $\mathrm{Al}_{2} \mathrm{O}_{3}$ & 10.06 & 9.63 & 9.45 & 9.46 & 9.74 & 9.53 & -5.28 & 10.05 & \begin{tabular}{|l|}
9.79 \\
\end{tabular} & 9.94 & 9.93 & 9.54 & 9.50 & 9.58 & 9.50 & 9.53 \\
\hline $\mathrm{B}_{2} \mathrm{O}_{3} *$ & 10.91 & 10.90 & 10.90 & 10.90 & 10.91 & 10.89 & $\mathrm{NC}$ & 10.90 & 10.90 & 10.90 & 10.90 & 10.90 & 10.90 & 10.90 & 10.90 & 10.90 \\
\hline $\mathrm{CaO}$ & 10.11 & 9.61 & 9.79 & 9.72 & 9.53 & 9.26 & -8.45 & 10.10 & 9.57 & 9.59 & 9.51 & 9.45 & 9.45 & 9.70 & 9.76 & 9.61 \\
\hline $\mathrm{Cl}$ & 0.01 & 0.01 & 0.01 & 0.01 & 0.01 & 0.02 & $\mathrm{NC}$ & 0.01 & 0.02 & 0.02 & 0.01 & 0.01 & 0.01 & $<0.01$ & 0.01 & 0.01 \\
\hline $\mathrm{Cr}_{2} \mathrm{O}_{3}$ & 0.11 & 0.21 & 0.21 & 0.21 & 0.20 & 0.20 & NC & 0.11 & 0.20 & 0.21 & 0.21 & 0.21 & 0.21 & 0.21 & 0.22 & 0.21 \\
\hline $\mathrm{F}$ & 0.07 & NA & NA & NA & NA & $\mathrm{NC}$ & NC & 0.07 & NA & NA & NA & NA & NA & NA & NA & NA \\
\hline $\mathrm{Fe}_{2} \mathrm{O}_{3}$ & 1.14 & 1.33 & 1.35 & 1.33 & 1.31 & 1.39 & 22.19 & 1.13 & 1.29 & 1.30 & 1.27 & 1.25 & 1.27 & 1.28 & 1.29 & 1.25 \\
\hline $\mathrm{I}$ & 0.10 & 0.02 & 0.03 & 0.03 & 0.03 & 0.03 & $\mathrm{NC}$ & 0.10 & 0.03 & 0.03 & 0.03 & 0.03 & 0.03 & 0.03 & 0.02 & 0.03 \\
\hline $\mathrm{K}_{2} \mathrm{O}$ & 0.40 & 0.60 & 0.60 & 0.58 & 0.59 & 0.70 & NC & 0.40 & 0.58 & 0.59 & 0.59 & 0.60 & 0.58 & 0.57 & 0.57 & 0.55 \\
\hline $\mathrm{Li}_{2} \mathrm{O}^{*}$ & 3.52 & 3.51 & 3.51 & 3.51 & 3.51 & 3.48 & $\mathrm{NC}$ & 3.51 & 3.51 & 3.51 & 3.51 & 3.51 & 3.51 & 3.51 & 3.51 & 3.51 \\
\hline $\mathrm{MgO}$ & 1.14 & 1.08 & 1.15 & 1.16 & 1.16 & 1.13 & -0.15 & 1.13 & 1.18 & 1.13 & 1.09 & 1.05 & 1.08 & 1.14 & 1.00 & 1.05 \\
\hline $\mathrm{Na}_{2} \mathrm{O}$ & 9.96 & 10.37 & 9.97 & 10.38 & 10.17 & 10.57 & 6.10 & 9.95 & 10.07 & 10.05 & 10.40 & 10.44 & 10.58 & 10.21 & 10.19 & 10.63 \\
\hline $\mathrm{P}_{2} \mathrm{O}_{5}$ & 0.03 & 0.08 & 0.08 & 0.08 & 0.08 & 0.08 & $\mathrm{NC}$ & 0.03 & 0.08 & 0.08 & 0.07 & 0.08 & 0.08 & 0.09 & 0.07 & 0.07 \\
\hline $\mathrm{SiO}_{2}$ & 42.73 & 42.83 & 42.79 & 42.52 & 42.90 & 43.11 & 0.90 & 42.69 & 43.05 & 42.76 & 42.62 & 43.24 & 43.02 & 42.86 & 42.88 & 42.80 \\
\hline $\mathrm{SO}_{3}$ & 1.50 & 1.15 & 1.16 & 1.16 & 1.17 & 1.14 & $\mathrm{NC}$ & 1.60 & 1.17 & 1.13 & 1.13 & 1.15 & 1.16 & 1.13 & 1.16 & 1.15 \\
\hline $\mathrm{TiO}_{2}$ & $\S$ & 0.24 & 0.24 & 0.25 & 0.24 & 0.26 & $\mathrm{NC}$ & $\S$ & 0.24 & 0.25 & 0.24 & 0.22 & 0.22 & 0.23 & 0.24 & 0.23 \\
\hline $\mathrm{V}_{2} \mathrm{O}_{5}$ & 1.23 & 1.43 & 1.44 & 1.42 & 1.38 & 1.35 & 10.25 & 1.22 & 1.40 & 1.38 & 1.40 & 1.37 & 1.37 & 1.42 & 1.46 & 1.39 \\
\hline $\mathrm{ZnO}$ & 3.51 & 3.35 & 3.45 & 3.46 & 3.35 & 3.24 & -7.64 & 3.50 & 3.35 & 3.32 & 3.35 & 3.26 & 3.30 & 3.44 & 3.42 & 3.33 \\
\hline $\mathrm{ZrO}_{2}$ & 3.51 & 3.65 & 3.88 & 3.83 & 3.72 & 3.63 & 3.47 & 3.50 & 3.56 & 3.80 & 3.73 & 3.70 & 3.73 & 3.70 & 3.79 & 3.74 \\
\hline Sum & 100.00 & 100.00 & 100.00 & 100.00 & 100.00 & 100.00 & $\mathrm{NC}$ & 100.00 & 100.00 & 100.00 & 100.00 & 100.00 & 100.00 & 100.00 & 100.00 & 100.00 \\
\hline
\end{tabular}

* - Target values calculated based on simple well-stirred tank model

NA - Not analyzed by XRF; NC - Not calculated

$\S-$ Not a target constituent 
Table 5.3. XRF Analyzed Composition for LAWB DM100 Discharged Glass Samples (wt\%) (continued).

\begin{tabular}{|c|c|c|c|c|c|c|c|c|c|c|c|c|c|c|c|c|}
\hline Test & \multicolumn{16}{|c|}{ B4 } \\
\hline Glass (kg) & - & 1063.78 & 1095.74 & 1118.42 & 1142.8 & 1167.2 & \begin{tabular}{|c|}
1192.76 \\
\end{tabular} & 1217.62 & 1244.56 & 1272.16 & 1293.94 & 1314.94 & 1338.76 & 1367.74 & 1391.6 & 1416.12 \\
\hline Element & Target & $\begin{array}{r}\mathrm{DWV}- \\
\mathrm{G}-137 \mathrm{~B}\end{array}$ & $\begin{array}{r}\text { DWV- } \\
\text { G-141A }\end{array}$ & $\begin{array}{r}\text { DWV- } \\
\text { G-141C }\end{array}$ & $\begin{array}{r}\text { DWV- } \\
\text { G-142A }\end{array}$ & $\begin{array}{r}\text { DWV- } \\
\text { G-142C }\end{array}$ & \begin{tabular}{|r|} 
DWV- \\
G-142E
\end{tabular} & $\begin{array}{r}\text { DWV- } \\
\text { G-143B }\end{array}$ & \begin{tabular}{|r|} 
DWV- \\
G-143D
\end{tabular} & $\begin{array}{r}\text { DWV- } \\
\text { G-148B }\end{array}$ & $\begin{array}{r}\text { DWV- } \\
\text { G-149B }\end{array}$ & $\begin{array}{r}\text { DWV- } \\
\text { G-150A }\end{array}$ & \begin{tabular}{|} 
DWV- \\
G-150C
\end{tabular} & $\begin{array}{r}\text { DWV- } \\
\text { G-151B }\end{array}$ & $\begin{array}{r}\text { DWV- } \\
\text { G-155B }\end{array}$ & $\begin{array}{r}\text { DWV- } \\
\text { G-155D }\end{array}$ \\
\hline $\mathrm{Al}_{2} \mathrm{O}_{3}$ & 10.05 & 9.48 & 9.48 & 9.58 & 9.51 & 9.50 & 9.59 & 9.56 & 9.53 & 9.67 & 9.95 & 9.72 & 9.90 & 9.89 & 9.57 & 9.59 \\
\hline $\mathrm{B}_{2} \mathrm{O}_{3} *$ & 10.90 & 10.90 & 10.90 & 10.90 & 10.90 & 10.90 & 10.90 & 10.90 & 10.90 & 10.90 & 10.90 & 10.90 & 10.90 & 10.90 & 10.90 & 10.90 \\
\hline $\mathrm{CaO}$ & 10.10 & 9.81 & 9.66 & 9.59 & 9.49 & 9.67 & 9.31 & 9.63 & 9.65 & 9.26 & 9.66 & 9.56 & 9.65 & 9.66 & 9.73 & 9.65 \\
\hline $\mathrm{Cl}$ & 0.01 & 0.01 & 0.01 & $<0.01$ & 0.01 & 0.01 & 0.01 & 0.01 & 0.01 & $<0.01$ & 0.01 & 0.01 & 0.01 & 0.01 & $<0.01$ & $<0.01$ \\
\hline $\mathrm{Cr}_{2} \mathrm{O}_{3}$ & 0.11 & 0.21 & 0.21 & 0.20 & 0.20 & 0.21 & 0.20 & 0.20 & 0.21 & 0.20 & 0.21 & 0.21 & 0.21 & 0.21 & 0.21 & 0.21 \\
\hline$F$ & 0.07 & NA & NA & NA & NA & NA & NA & NA & NA & NA & NA & NA & NA & NA & NA & NA \\
\hline $\mathrm{Fe}_{2} \mathrm{O}_{3}$ & 1.13 & 1.28 & 1.28 & 1.23 & 1.22 & 1.26 & 1.19 & 1.24 & 1.24 & 1.15 & 1.25 & 1.24 & 1.25 & 1.23 & 1.25 & 1.25 \\
\hline I & 0.10 & 0.02 & 0.03 & 0.02 & 0.03 & 0.03 & 0.03 & 0.02 & 0.03 & 0.03 & 0.03 & 0.02 & 0.02 & 0.03 & 0.03 & 0.03 \\
\hline $\mathrm{K}_{2} \mathrm{O}$ & 0.40 & 0.57 & 0.55 & 0.60 & 0.57 & 0.58 & 0.57 & 0.58 & 0.58 & 0.56 & 0.56 & 0.56 & 0.56 & 0.57 & 0.60 & 0.59 \\
\hline $\mathrm{Li}_{2} \mathrm{O}^{*}$ & 3.51 & 3.51 & 3.51 & 3.51 & 3.51 & 3.51 & 3.51 & 3.51 & 3.51 & 3.51 & 3.51 & 3.51 & 3.51 & 3.51 & 3.51 & 3.51 \\
\hline $\mathrm{MgO}$ & 1.13 & 1.03 & 1.05 & 1.00 & 1.06 & 0.97 & 1.07 & 1.05 & 1.07 & 1.06 & 1.02 & 1.04 & 1.02 & 1.02 & 1.00 & 0.99 \\
\hline $\mathrm{Na}_{2} \mathrm{O}$ & 9.95 & 10.40 & 10.68 & 10.33 & 10.66 & 10.36 & 10.61 & 10.25 & 10.17 & 10.65 & 9.97 & 10.81 & 10.37 & 9.95 & 10.08 & 10.04 \\
\hline $\mathrm{P}_{2} \mathrm{O}_{5}$ & 0.03 & 0.07 & 0.08 & 0.09 & 0.07 & 0.07 & 0.08 & 0.07 & 0.08 & 0.08 & 0.08 & 0.08 & 0.07 & 0.08 & 0.08 & 0.08 \\
\hline $\mathrm{SiO}_{2}$ & 42.69 & 42.76 & 42.75 & 43.42 & 43.32 & 43.26 & 43.71 & 43.29 & 43.31 & 43.82 & 43.06 & 42.92 & 42.88 & 43.24 & 43.47 & 43.57 \\
\hline $\mathrm{SO}_{3}$ & 1.60 & 1.14 & 1.15 & 1.15 & 1.17 & 1.15 & 1.17 & 1.14 & 1.14 & 1.16 & 1.15 & 1.16 & 1.16 & 1.17 & 1.18 & 1.18 \\
\hline $\mathrm{TiO}_{2}$ & $\S$ & 0.24 & 0.22 & 0.22 & 0.22 & 0.22 & 0.21 & 0.23 & 0.22 & 0.21 & 0.24 & 0.23 & 0.24 & 0.23 & 0.21 & 0.22 \\
\hline $\mathrm{V}_{2} \mathrm{O}_{5}$ & 1.22 & 1.43 & 1.43 & 1.39 & 1.39 & 1.41 & 1.34 & 1.39 & 1.41 & 1.36 & 1.40 & 1.39 & 1.44 & 1.42 & 1.44 & 1.42 \\
\hline $\mathrm{ZnO}$ & 3.50 & 3.37 & 3.26 & 3.17 & 3.12 & 3.28 & 3.09 & 3.28 & 3.33 & 3.05 & 3.32 & 3.21 & 3.26 & 3.22 & 3.20 & 3.24 \\
\hline $\mathrm{ZrO}_{2}$ & 3.50 & 3.76 & 3.75 & 3.59 & 3.54 & 3.61 & 3.43 & 3.64 & 3.59 & 3.34 & 3.68 & 3.42 & 3.54 & 3.67 & 3.53 & 3.53 \\
\hline Sum & 100.00 & 100.00 & 100.00 & 100.00 & 100.00 & 100.00 & 100.00 & 100.00 & 100.00 & 100.00 & 100.00 & 100.00 & 100.00 & 100.00 & 100.00 & 100.00 \\
\hline
\end{tabular}

* - Target values calculated based on simple well-stirred tank model

NA - Not analyzed by XRF; NC - Not calculated

$\S-$ Not a target constituent 
Table 5.3. XRF Analyzed Composition for LAWB DM100 Discharged Glass Samples (wt\%) (continued).

\begin{tabular}{|c|c|c|c|c|c|c|c|c|}
\hline Test & \multicolumn{8}{|c|}{ B4 } \\
\hline Glass (kg) & - & 1440.6 & 1466.46 & 1490.8 & 1514.02 & 1538.8 & $1217-$ & $39 \mathrm{~kg}$ \\
\hline Element & Target & $\begin{array}{c}\text { EWV-G- } \\
9 \mathrm{~B}\end{array}$ & $\begin{array}{c}\text { EWV-G- } \\
\text { 9D }\end{array}$ & $\begin{array}{c}\text { EWV-G- } \\
10 \mathrm{~A}\end{array}$ & $\begin{array}{c}\text { EWV-G- } \\
10 \mathrm{C}\end{array}$ & $\begin{array}{c}\text { EWV-G- } \\
11 \mathrm{~A}\end{array}$ & Avg. & \%Dev. \\
\hline $\mathrm{Al}_{2} \mathrm{O}_{3}$ & 10.05 & 9.68 & 9.43 & 9.94 & 9.62 & 9.34 & 9.67 & -3.77 \\
\hline $\mathrm{B}_{2} \mathrm{O}_{3} *$ & 10.90 & 10.90 & 10.90 & 10.90 & 10.90 & 10.90 & 10.90 & $\mathrm{NC}$ \\
\hline $\mathrm{CaO}$ & 10.10 & 9.21 & 9.61 & 9.75 & 9.50 & 9.74 & 9.59 & -5.03 \\
\hline $\mathrm{Cl}$ & 0.01 & 0.01 & 0.01 & 0.02 & $<0.01$ & 0.01 & 0.01 & NC \\
\hline $\mathrm{Cr}_{2} \mathrm{O}_{3}$ & 0.11 & 0.20 & 0.21 & 0.21 & 0.20 & 0.21 & 0.21 & $\mathrm{NC}$ \\
\hline $\mathrm{F}$ & 0.07 & NA & NA & NA & NA & NA & $\mathrm{NC}$ & NC \\
\hline $\mathrm{Fe}_{2} \mathrm{O}_{3}$ & 1.13 & 1.21 & 1.24 & 1.34 & 1.22 & 1.28 & 1.24 & 9.55 \\
\hline I & 0.10 & 0.03 & 0.03 & 0.03 & 0.02 & 0.03 & 0.03 & $\mathrm{NC}$ \\
\hline $\mathrm{K}_{2} \mathrm{O}$ & 0.40 & 0.56 & 0.57 & 0.57 & 0.57 & 0.57 & 0.57 & NC \\
\hline $\mathrm{Li}_{2} \mathrm{O}^{*}$ & 3.51 & 3.51 & 3.51 & 3.51 & 3.51 & 3.51 & 3.51 & $\mathrm{NC}$ \\
\hline $\mathrm{MgO}$ & 1.13 & 1.10 & 1.02 & 1.04 & 1.09 & 1.08 & 1.04 & -8.03 \\
\hline $\mathrm{Na}_{2} \mathrm{O}$ & 9.95 & 10.89 & 10.61 & 9.86 & 10.44 & 10.17 & 10.30 & 3.56 \\
\hline $\mathrm{P}_{2} \mathrm{O}_{5}$ & 0.03 & 0.07 & 0.08 & 0.08 & 0.08 & 0.08 & 0.08 & $\mathrm{NC}$ \\
\hline $\mathrm{SiO}_{2}$ & 42.69 & 43.55 & 43.10 & 42.73 & 43.45 & 43.05 & 43.25 & 1.31 \\
\hline $\mathrm{SO}_{3}$ & 1.60 & 1.16 & 1.13 & 1.15 & 1.16 & 1.14 & 1.15 & $\mathrm{NC}$ \\
\hline $\mathrm{TiO}_{2}$ & $\S$ & 0.20 & 0.22 & 0.24 & 0.21 & 0.22 & 0.22 & $\mathrm{NC}$ \\
\hline $\mathrm{V}_{2} \mathrm{O}_{5}$ & 1.22 & 1.35 & 1.40 & 1.43 & 1.37 & 1.43 & 1.41 & 14.86 \\
\hline $\mathrm{ZnO}$ & 3.50 & 3.06 & 3.25 & 3.40 & 3.24 & 3.47 & 3.25 & -7.16 \\
\hline $\mathrm{ZrO}_{2}$ & 3.50 & 3.32 & 3.69 & 3.80 & 3.44 & 3.77 & 3.57 & 1.89 \\
\hline Sum & 100.00 & 100.00 & 100.00 & 100.00 & 100.00 & 100.00 & 100.00 & $\mathrm{NC}$ \\
\hline
\end{tabular}

* - Target values calculated based on simple well-stirred tank model

NA - Not analyzed by XRF; NC - Not calculated

$\S-$ Not a target constituent 
Table 5.4. XRF Analyzed Composition for LAWA DM100 Discharged Glass Samples (wt\%).

\begin{tabular}{|c|c|c|c|c|c|c|c|c|c|c|c|c|c|c|c|c|c|}
\hline Test & \multicolumn{17}{|c|}{ A3 } \\
\hline Glass (kg) & -- & 27.32 & 43.78 & 74.24 & 102.86 & 133.18 & 149.82 & 169.44 & 194.90 & 215.16 & 235.46 & 254.50 & 278.04 & 306.14 & 324.32 & 364.32 & 385.10 \\
\hline Element & Target & $\begin{array}{l}\text { EWV- } \\
\text { G-32B }\end{array}$ & $\begin{array}{l}\text { EWV- } \\
\text { G-33B }\end{array}$ & $\begin{array}{l}\text { EWV- } \\
\text { G-35A }\end{array}$ & $\begin{array}{l}\text { EWV- } \\
\text { G-35C }\end{array}$ & $\begin{array}{l}\text { EWV- } \\
\text { G-37B }\end{array}$ & $\begin{array}{l}\text { EWV- } \\
\text { G-40A }\end{array}$ & \begin{tabular}{|l|} 
EWV- \\
G-41A
\end{tabular} & $\begin{array}{l}\text { EWV- } \\
\text { G-43B }\end{array}$ & $\begin{array}{l}\text { EWV- } \\
\text { G-46A }\end{array}$ & \begin{tabular}{|l} 
EWV- \\
G-49A
\end{tabular} & $\begin{array}{l}\text { EWV- } \\
\text { G-49C }\end{array}$ & $\begin{array}{l}\text { EWV- } \\
\text { G-51B }\end{array}$ & \begin{tabular}{|l} 
EWV- \\
G-53A
\end{tabular} & \begin{tabular}{|l|} 
EWV- \\
G-53C
\end{tabular} & $\begin{array}{l}\text { EWV- } \\
\text { G-57B }\end{array}$ & $\begin{array}{l}\text { EWV- } \\
\text { G-58A }\end{array}$ \\
\hline $\mathrm{Al}_{2} \mathrm{O}_{3}$ & 10.62 & 9.79 & 9.80 & 9.86 & 9.85 & 10.11 & 10.12 & \begin{tabular}{|l|}
10.09 \\
\end{tabular} & 10.27 & 10.44 & 10.56 & 10.43 & 10.55 & 10.66 & 10.41 & 10.48 & 10.46 \\
\hline $\mathrm{B}_{2} \mathrm{O}_{3} *$ & 12.75 & 11.27 & 11.46 & 11.75 & 11.96 & 12.14 & 12.22 & 12.30 & 12.38 & 12.44 & 12.49 & 12.53 & 12.57 & 12.61 & 12.63 & 12.66 & 12.68 \\
\hline $\mathrm{CaO}$ & 6.47 & 8.90 & 9.00 & 8.38 & 7.89 & 7.39 & 7.46 & 6.99 & 6.67 & 6.79 & 6.52 & 6.43 & 6.28 & 6.19 & 6.32 & 5.98 & 5.93 \\
\hline $\mathrm{Cl}$ & 0.65 & 0.03 & 0.09 & 0.16 & 0.22 & 0.22 & 0.27 & 0.26 & 0.27 & 0.28 & 0.27 & 0.29 & 0.30 & 0.30 & 0.31 & 0.31 & 0.31 \\
\hline $\mathrm{Cr}_{2} \mathrm{O}_{3}$ & 0.52 & 0.20 & 0.27 & 0.33 & 0.40 & 0.43 & 0.46 & 0.47 & 0.48 & 0.53 & 0.52 & 0.54 & 0.56 & 0.57 & 0.63 & 0.60 & 0.61 \\
\hline $\mathrm{F}$ & $<0.01$ & NA & NA & NA & NA & NA & NA & NA & NA & NA & NA & NA & NA & NA & NA & NA & NA \\
\hline $\mathrm{Fe}_{2} \mathrm{O}_{3}$ & 0.90 & 1.20 & 1.24 & 1.21 & 1.12 & 1.07 & 1.07 & 1.01 & 0.97 & 1.08 & 0.98 & 0.95 & 0.94 & 0.95 & 0.99 & 0.95 & 0.90 \\
\hline I & 0.10 & 0.00 & 0.01 & 0.01 & 0.02 & 0.02 & 0.02 & 0.02 & 0.02 & 0.02 & 0.02 & 0.02 & 0.02 & 0.03 & 0.02 & 0.02 & 0.03 \\
\hline $\mathrm{K}_{2} \mathrm{O}$ & 0.51 & 0.57 & 0.57 & 0.57 & 0.58 & 0.59 & 0.61 & 0.59 & 0.58 & 0.60 & 0.58 & 0.57 & 0.59 & 0.58 & 0.59 & 0.60 & 0.59 \\
\hline $\mathrm{Li}_{2} \mathrm{O}^{*}$ & $\S$ & 2.80 & 2.44 & 1.89 & 1.49 & 1.16 & 1.01 & 0.86 & 0.69 & 0.58 & 0.49 & 0.42 & 0.35 & 0.27 & 0.24 & 0.17 & 0.14 \\
\hline $\mathrm{MgO}$ & 0.90 & 1.16 & 1.13 & 1.12 & 1.13 & 1.16 & 1.03 & 1.10 & 1.07 & 1.07 & 1.13 & 1.12 & 1.02 & 1.05 & 1.07 & 1.05 & 1.00 \\
\hline $\mathrm{Na}_{2} \mathrm{O}$ & 22.93 & 11.97 & 12.21 & 14.58 & 16.75 & 17.34 & 16.96 & 18.97 & 19.42 & 19.16 & 19.68 & 20.52 & 20.93 & 20.97 & 20.80 & 21.36 & 21.61 \\
\hline $\mathrm{P}_{2} \mathrm{O}_{5}$ & $\S$ & 0.07 & 0.07 & 0.05 & 0.05 & 0.05 & 0.04 & 0.00 & 0.04 & 0.04 & 0.04 & 0.03 & 0.04 & 0.03 & 0.02 & 0.03 & 0.02 \\
\hline $\mathrm{SiO}_{2}$ & 34.75 & 43.19 & 42.09 & 40.69 & 39.15 & 39.38 & 39.74 & 38.80 & 38.74 & 38.18 & 38.32 & 37.86 & 37.68 & 37.45 & 37.14 & 37.50 & 37.54 \\
\hline $\mathrm{SnO}_{2}$ & 1.00 & 0.05 & 0.19 & 0.35 & 0.56 & 0.59 & 0.62 & 0.62 & 0.73 & 0.78 & 0.78 & 0.78 & 0.75 & 0.88 & 0.96 & 0.94 & 0.90 \\
\hline $\mathrm{SO}_{3}$ & 0.95 & 1.05 & 1.06 & 0.97 & 0.90 & 0.90 & 0.89 & 0.84 & 0.82 & 0.79 & 0.80 & 0.79 & 0.78 & 0.77 & 0.80 & 0.75 & 0.79 \\
\hline $\mathrm{TiO}_{2}$ & $\S$ & 0.21 & 0.21 & 0.20 & 0.18 & 0.16 & 0.16 & 0.15 & 0.14 & 0.16 & 0.14 & 0.13 & 0.14 & 0.14 & 0.14 & 0.12 & 0.12 \\
\hline $\mathrm{V}_{2} \mathrm{O}_{5}$ & 0.97 & 1.27 & 1.31 & 1.26 & 1.19 & 1.12 & 1.14 & 1.07 & 1.01 & 1.05 & 1.00 & 1.00 & 0.97 & 0.95 & 0.99 & 0.91 & 0.91 \\
\hline $\mathrm{ZnO}$ & 2.99 & 3.02 & 3.25 & 3.17 & 3.13 & 2.99 & 3.03 & 2.89 & 2.74 & 2.92 & 2.76 & 2.76 & 2.77 & 2.77 & 2.88 & 2.72 & 2.69 \\
\hline $\mathrm{ZrO}_{2}$ & 2.99 & 3.26 & 3.60 & 3.46 & 3.45 & 3.20 & 3.15 & 2.98 & 2.95 & 3.08 & 2.91 & 2.82 & 2.77 & 2.83 & 3.06 & 2.85 & 2.78 \\
\hline Sum & 100.00 & 100.00 & \begin{tabular}{|l|}
100.00 \\
\end{tabular} & 100.00 & 100.00 & 100.00 & 100.00 & \begin{tabular}{|l|}
100.00 \\
\end{tabular} & 100.00 & 100.00 & 100.00 & \begin{tabular}{|l|}
100.00 \\
\end{tabular} & 100.00 & 100.00 & \begin{tabular}{|l|}
100.00 \\
\end{tabular} & 100.00 & 100.00 \\
\hline
\end{tabular}

* - Target values calculated based on simple well-stirred tank model

NA - Not analyzed by XRF; NC - Not calculated

$\S-$ Not a target constituent 
Table 5.4. XRF Analyzed Compositions for LAWA DM100 Discharged Glass Samples (wt\%) (continued).

\begin{tabular}{|c|c|c|c|c|c|c|c|c|c|c|c|c|c|c|c|c|}
\hline Test & \multicolumn{16}{|c|}{ A3 } \\
\hline Glass (kg) & - & 423.66 & 448.58 & 468.60 & 487.92 & 517.84 & 541.00 & 565.68 & 589.44 & 613.30 & 632.66 & 652.04 & 674.34 & 692.58 & 714.16 & 737.92 \\
\hline \multirow{2}{*}{ Element } & \multirow{2}{*}{ Target } & EWV- & EWV- & EWV- & EWV- & EWV- & EWV- & EWV- & EWV- & EWV- & EWV- & EWV- & EWV- & EWV- & EWV- & EWV- \\
\hline & & G-60C & G-65B & G-66A & G-66C & G-67B & G-69B & G-72A & G-72C & G-75B & G-76B & G-77A & G-78B & G-79B & G-83B & G-84B \\
\hline $\mathrm{Al}_{2} \mathrm{O}_{3}$ & 10.62 & 10.28 & 10.69 & 10.39 & 10.56 & 10.49 & 10.59 & 10.58 & 10.54 & 10.58 & 10.61 & 10.67 & 10.49 & 10.51 & 10.42 & 10.66 \\
\hline $\mathrm{B}_{2} \mathrm{O}_{3}{ }^{*}$ & 12.75 & 12.70 & 12.71 & 12.71 & 12.72 & 12.73 & 12.73 & 12.73 & 12.74 & 12.74 & 12.74 & 12.74 & 12.74 & 12.74 & 12.75 & 12.75 \\
\hline $\mathrm{CaO}$ & 6.47 & 6.13 & 5.90 & 5.92 & 5.87 & 5.83 & 5.78 & 5.71 & 5.67 & 5.80 & 5.57 & 5.69 & 5.65 & 5.64 & 5.96 & 5.68 \\
\hline $\mathrm{Cl}$ & 0.65 & 0.32 & 0.31 & 0.32 & 0.31 & 0.32 & 0.33 & 0.33 & 0.32 & 0.32 & 0.32 & 0.32 & 0.32 & 0.33 & 0.35 & 0.33 \\
\hline $\mathrm{Cr}_{2} \mathrm{O}_{3}$ & 0.52 & 0.66 & 0.63 & 0.64 & 0.64 & 0.65 & 0.66 & 0.64 & 0.65 & 0.68 & 0.66 & 0.67 & 0.67 & 0.68 & 0.72 & 0.68 \\
\hline $\mathrm{F}$ & $<0.01$ & NA & NA & NA & NA & NA & NA & NA & NA & NA & NA & NA & NA & NA & NA & NA \\
\hline $\mathrm{Fe}_{2} \mathrm{O}_{3}$ & 0.90 & 0.99 & 0.91 & 0.93 & 0.93 & 0.90 & 0.91 & 0.92 & 0.97 & 0.94 & 0.87 & 0.90 & 0.91 & 0.89 & 0.96 & 0.91 \\
\hline I & 0.10 & 0.03 & 0.04 & 0.03 & 0.03 & 0.04 & 0.04 & 0.03 & 0.04 & 0.04 & 0.03 & 0.03 & 0.03 & 0.03 & 0.03 & 0.03 \\
\hline $\mathrm{K}_{2} \mathrm{O}$ & 0.51 & 0.61 & 0.58 & 0.58 & 0.59 & 0.57 & 0.58 & 0.60 & 0.58 & 0.60 & 0.59 & 0.61 & 0.59 & 0.58 & 0.60 & 0.58 \\
\hline $\mathrm{Li}_{2} \mathrm{O}^{*}$ & $\S$ & 0.10 & 0.08 & 0.07 & 0.06 & 0.05 & 0.04 & 0.03 & 0.03 & 0.02 & 0.02 & 0.02 & 0.01 & 0.01 & 0.01 & 0.01 \\
\hline $\mathrm{MgO}$ & 0.90 & 1.01 & 1.05 & 0.97 & 0.99 & 1.00 & 1.04 & 0.96 & 0.94 & 0.90 & 0.97 & 0.93 & 1.01 & 1.01 & 0.86 & 1.03 \\
\hline $\mathrm{Na}_{2} \mathrm{O}$ & 22.93 & 20.92 & 21.61 & 21.83 & 21.88 & 22.05 & 22.07 & 21.84 & 22.40 & 21.87 & 22.69 & 22.31 & 22.88 & 22.80 & 22.24 & 22.91 \\
\hline $\mathrm{P}_{2} \mathrm{O}_{5}$ & $\S$ & 0.03 & 0.02 & 0.02 & 0.02 & 0.02 & 0.03 & 0.02 & 0.02 & 0.03 & 0.00 & 0.02 & 0.02 & 0.02 & 0.02 & 0.02 \\
\hline $\mathrm{SiO}_{2}$ & 34.75 & 37.00 & 36.92 & 36.76 & 36.76 & 36.64 & 36.59 & 37.10 & 36.73 & 36.69 & 36.78 & 36.59 & 36.16 & 36.25 & 36.11 & 36.31 \\
\hline $\mathrm{SnO}_{2}$ & 1.00 & 1.19 & 1.06 & 1.19 & 1.09 & 1.19 & 1.11 & 1.15 & 1.13 & 1.18 & 1.02 & 1.08 & 1.15 & 1.16 & 1.16 & 0.96 \\
\hline $\mathrm{SO}_{3}$ & 0.95 & 0.78 & 0.78 & 0.76 & 0.76 & 0.78 & 0.77 & 0.77 & 0.75 & 0.77 & 0.75 & 0.79 & 0.74 & 0.77 & 0.77 & 0.77 \\
\hline $\mathrm{TiO}_{2}$ & $\S$ & 0.13 & 0.13 & 0.12 & 0.13 & 0.12 & 0.12 & 0.12 & 0.12 & 0.12 & 0.11 & 0.11 & 0.12 & 0.12 & 0.13 & 0.12 \\
\hline $\mathrm{V}_{2} \mathrm{O}_{5}$ & 0.97 & 0.96 & 0.91 & 0.91 & 0.90 & 0.88 & 0.88 & 0.87 & 0.85 & 0.88 & 0.82 & 0.85 & 0.84 & 0.83 & 0.88 & 0.81 \\
\hline $\mathrm{ZnO}$ & 2.99 & 2.95 & 2.74 & 2.79 & 2.78 & 2.75 & 2.77 & 2.71 & 2.69 & 2.80 & 2.67 & 2.77 & 2.75 & 2.74 & 2.95 & 2.74 \\
\hline $\mathrm{ZrO}_{2}$ & 2.99 & 3.19 & 2.92 & 3.05 & 2.97 & 3.00 & 2.95 & 2.89 & 2.85 & 3.02 & 2.77 & 2.89 & 2.92 & 2.87 & 3.08 & 2.71 \\
\hline Sum & 100.00 & 100.00 & 100.00 & 100.00 & 100.00 & 100.00 & 100.00 & 100.00 & 100.00 & 100.00 & 100.00 & 100.00 & 100.00 & 100.00 & 100.00 & 100.00 \\
\hline
\end{tabular}

* - Target values calculated based on simple well-stirred tank model

NA - Not analyzed by XRF; NC - Not calculated

$\S-$ Not a target constituent 
Table 5.4. XRF Analyzed Compositions for LAWA DM100 Discharged Glass Samples (wt\%) (continued).

\begin{tabular}{|c|c|c|c|c|c|c|c|c|c|c|c|c|c|c|c|c|c|}
\hline \multirow{3}{*}{$\begin{array}{c}\text { Test } \\
\text { Glass (kg) } \\
\text { Element }\end{array}$} & \multicolumn{5}{|c|}{ A3 } & \multicolumn{12}{|c|}{ A4 } \\
\hline & - & 762.12 & 787.20 & $306-7$ & $88 \mathrm{~kg}$ & - & 812.96 & 833.42 & 853.96 & 879.42 & 900.20 & 925.32 & 950.14 & 972.66 & 990.60 & 1013.48 & 1034.62 \\
\hline & Target & $\begin{array}{l}\text { EWV- } \\
\text { G-85B }\end{array}$ & \begin{tabular}{|l|} 
EWV- \\
G-89B
\end{tabular} & Avg. & \%Dev. & Target & \begin{tabular}{|l|} 
EWV- \\
G-93B
\end{tabular} & \begin{tabular}{|l|} 
EWV- \\
G-94B
\end{tabular} & $\begin{array}{l}\text { EWV- } \\
\text { G-95B }\end{array}$ & \begin{tabular}{|l} 
EWV- \\
G-96A
\end{tabular} & $\begin{array}{l}\text { EWV- } \\
\text { G-100A }\end{array}$ & $\begin{array}{l}\text { EWV- } \\
\text { G-101A }\end{array}$ & \begin{tabular}{|c} 
EWV- \\
G-101C
\end{tabular} & $\begin{array}{l}\text { EWV- } \\
\text { G-103B }\end{array}$ & \begin{tabular}{|c|} 
EWV- \\
G-104A
\end{tabular} & $\begin{array}{l}\text { EWV- } \\
\text { G-104C }\end{array}$ & $\begin{array}{l}\text { EWV- } \\
\text { G-107A }\end{array}$ \\
\hline $\mathrm{Al}_{2} \mathrm{O}_{3}$ & 10.62 & 10.64 & \begin{tabular}{|l|}
10.62 \\
\end{tabular} & 10.54 & -0.73 & 10.61 & 10.45 & 10.56 & 10.46 & \begin{tabular}{|l|}
10.55 \\
\end{tabular} & 10.43 & 10.41 & 10.41 & 10.48 & 10.55 & 10.47 & 10.40 \\
\hline $\mathrm{B}_{2} \mathrm{O}_{3} *$ & 12.75 & 12.75 & 12.75 & 12.72 & $\mathrm{NC}$ & 12.74 & 12.75 & 12.75 & 12.74 & 12.74 & 12.74 & 12.74 & 12.74 & 12.74 & 12.74 & 12.74 & 12.74 \\
\hline $\mathrm{CaO}$ & 6.47 & 5.70 & 5.71 & 5.84 & -9.66 & 6.46 & 5.69 & 5.78 & 5.85 & 5.88 & 5.89 & 5.87 & 5.85 & 5.87 & 5.71 & 5.77 & 5.84 \\
\hline $\mathrm{Cl}$ & 0.65 & 0.33 & 0.34 & 0.32 & $\mathrm{NC}$ & 0.65 & 0.34 & 0.34 & 0.31 & 0.32 & 0.32 & 0.31 & 0.32 & 0.33 & 0.32 & 0.32 & 0.32 \\
\hline $\mathrm{Cr}_{2} \mathrm{O}_{3}$ & 0.52 & 0.68 & 0.70 & 0.65 & $\mathrm{NC}$ & 0.52 & 0.69 & 0.71 & 0.73 & 0.72 & 0.71 & 0.71 & 0.70 & 0.71 & 0.68 & 0.70 & 0.71 \\
\hline $\mathrm{F}$ & $<0.01$ & NA & NA & 0.00 & $\mathrm{NC}$ & $<0.01$ & NA & NA & NA & NA & NA & NA & NA & NA & NA & NA & NA \\
\hline $\mathrm{Fe}_{2} \mathrm{O}_{3}$ & 0.90 & 0.91 & 0.95 & 0.93 & $\mathrm{NC}$ & 0.90 & 0.94 & 0.93 & 0.95 & 0.94 & 0.97 & 0.98 & 1.00 & 0.96 & 0.94 & 0.94 & 0.95 \\
\hline I & 0.10 & 0.03 & 0.03 & 0.03 & NC & 0.10 & 0.05 & 0.04 & 0.04 & 0.04 & 0.04 & 0.04 & 0.04 & 0.04 & 0.04 & 0.04 & 0.04 \\
\hline $\mathrm{K}_{2} \mathrm{O}$ & 0.51 & 0.58 & 0.58 & 0.59 & $\mathrm{NC}$ & 0.51 & 0.59 & 0.58 & 0.61 & 0.61 & 0.60 & 0.59 & 0.59 & 0.59 & 0.57 & 0.57 & 0.59 \\
\hline $\mathrm{Li}_{2} \mathrm{O}^{*}$ & $\S$ & 0.01 & $<0.01$ & 0.07 & $\mathrm{NC}$ & $\S$ & $<0.01$ & $<0.01$ & $<0.01$ & $<0.01$ & $<0.01$ & $<0.01$ & $<0.01$ & $<0.01$ & $<0.01$ & $<0.01$ & $<0.01$ \\
\hline $\mathrm{MgO}$ & 0.90 & 1.04 & 1.00 & 0.99 & $\mathrm{NC}$ & 0.90 & 0.88 & 0.89 & 0.92 & 0.97 & 0.99 & 1.01 & 0.99 & 1.05 & 1.08 & 1.11 & 1.01 \\
\hline $\mathrm{Na}_{2} \mathrm{O}$ & 22.93 & 23.13 & 23.02 & 22.06 & -3.81 & 22.91 & 22.51 & 22.01 & 21.89 & 21.29 & 21.58 & 21.53 & 21.59 & 21.34 & 22.03 & 22.15 & 21.88 \\
\hline $\mathrm{P}_{2} \mathrm{O}_{5}$ & $\S$ & 0.02 & 0.02 & 0.02 & $\mathrm{NC}$ & $\S$ & 0.02 & 0.02 & 0.02 & 0.02 & 0.02 & 0.02 & 0.03 & $<0.01$ & 0.02 & 0.02 & 0.02 \\
\hline $\mathrm{SiO}_{2}$ & 34.75 & 36.02 & 35.80 & 36.71 & 5.62 & 34.72 & 36.40 & 36.47 & 36.30 & 36.80 & 36.42 & 36.55 & 36.40 & 36.67 & 36.38 & 36.11 & 36.11 \\
\hline $\mathrm{SnO}_{2}$ & 1.00 & 0.95 & 1.05 & 1.07 & 7.18 & 1.00 & 1.23 & 1.26 & 1.27 & 1.25 & 1.31 & 1.26 & 1.33 & 1.28 & 1.26 & 1.26 & 1.31 \\
\hline $\mathrm{SO}_{3}$ & 0.95 & 0.76 & 0.80 & 0.77 & $\mathrm{NC}$ & 1.05 & 0.77 & 0.79 & 0.82 & 0.82 & 0.80 & 0.83 & 0.81 & 0.84 & 0.80 & 0.81 & 0.90 \\
\hline $\mathrm{TiO}_{2}$ & $\S$ & 0.12 & 0.12 & 0.12 & NC & $\S$ & 0.11 & 0.12 & 0.12 & 0.12 & 0.12 & 0.13 & 0.12 & 0.12 & 0.13 & 0.12 & 0.13 \\
\hline $\mathrm{V}_{2} \mathrm{O}_{5}$ & 0.97 & 0.81 & 0.83 & 0.88 & -9.45 & 0.97 & 0.85 & 0.87 & 0.91 & 0.95 & 0.96 & 0.96 & 0.99 & 0.98 & 0.96 & 0.99 & 1.04 \\
\hline $\mathrm{ZnO}$ & 2.99 & 2.76 & 2.82 & 2.77 & -7.14 & 2.98 & 2.77 & 2.82 & 2.89 & 2.88 & 2.91 & 2.87 & 2.87 & 2.85 & 2.74 & 2.79 & 2.85 \\
\hline $\mathrm{ZrO}_{2}$ & 2.99 & 2.76 & 2.85 & 2.92 & -2.37 & 2.98 & 2.97 & 3.04 & 3.15 & 3.09 & 3.20 & 3.16 & 3.20 & 3.15 & 3.03 & 3.08 & 3.16 \\
\hline Sum & 100.00 & 100.00 & 100.00 & 100.00 & $\mathrm{NC}$ & 100.00 & 100.00 & 100.00 & 100.00 & 100.00 & 100.00 & 100.00 & 100.00 & 100.00 & 100.00 & 100.00 & 100.00 \\
\hline
\end{tabular}

* - Target values calculated based on simple well-stirred tank model

NA - Not analyzed by XRF; NC - Not calculated

$\S-$ Not a target constituent 
Table 5.4. XRF Analyzed Compositions for LAWA DM100 Discharged Glass Samples (wt\%) (continued).

\begin{tabular}{|c|c|c|c|c|c|c|c|c|c|c|c|c|c|c|c|c|c|}
\hline Test & \multicolumn{17}{|c|}{ A4 } \\
\hline Glass (kg) & - & 1050.42 & 1081.96 & 1111.00 & 1131.32 & 1147.54 & 1172.96 & 1206.80 & 1223.80 & 1246.14 & 1261.86 & 1279.60 & \begin{tabular}{|l|l|}
0 & 1297.40 \\
\end{tabular} & 1327.52 & 1349.34 & 1365.16 & 1388.86 \\
\hline Element & Target & $\begin{array}{r}\text { EWV- } \\
\text { G-107C }\end{array}$ & $\begin{array}{r}\text { EWV- } \\
\text { G-108B }\end{array}$ & $\begin{array}{r}\text { EWV- } \\
\text { G-113A }\end{array}$ & $\begin{array}{r}\text { EWV- } \\
\text { G-115A }\end{array}$ & $\begin{array}{r}\text { EWV- } \\
\text { G-116A }\end{array}$ & $\begin{array}{r}\text { EWV- } \\
\text { G-117A }\end{array}$ & $\begin{array}{r}\text { EWV- } \\
\text { G-118B }\end{array}$ & $\begin{array}{r}\text { EWV- } \\
\text { G-120B }\end{array}$ & $\begin{array}{r}\text { EWV- } \\
\text { G-123B }\end{array}$ & $\begin{array}{r}\text { EWV- } \\
\text { G-124A }\end{array}$ & $\begin{array}{r}\text { EWV- } \\
\text { G-124C }\end{array}$ & $\begin{array}{r}\text { EWV- } \\
G-125 A\end{array}$ & $\begin{array}{r}\text { EWV- } \\
\text { G-127A }\end{array}$ & $\begin{array}{r}\text { EWV- } \\
\text { G-129A }\end{array}$ & $\begin{array}{r}\text { EWV- } \\
\text { G-129C }\end{array}$ & $\begin{array}{r}\text { EWV- } \\
\text { G-132B }\end{array}$ \\
\hline $\mathrm{Al}_{2} \mathrm{O}_{3}$ & 10.61 & \begin{tabular}{|l|}
10.38 \\
\end{tabular} & 10.42 & 10.42 & 10.48 & 10.58 & 10.50 & 10.51 & 10.35 & 10.44 & 10.36 & 10.47 & 10.47 & 10.63 & 10.46 & 10.56 & 10.50 \\
\hline $\mathrm{B}_{2} \mathrm{O}_{3}$ & 12.74 & 12.74 & 12.74 & 12.74 & 12.74 & 12.74 & 12.74 & 12.74 & 12.74 & 12.74 & 12.74 & 12.74 & 12.74 & 12.74 & 12.74 & 12.74 & 12.74 \\
\hline $\mathrm{CaO}$ & 6.46 & 5.81 & 6.05 & 5.64 & 5.59 & 5.86 & 5.51 & 5.80 & 5.90 & 5.84 & 6.00 & 5.86 & 5.78 & 5.88 & 5.77 & 5.81 & 5.74 \\
\hline $\mathrm{Cl}$ & 0.65 & 0.32 & 0.34 & 0.32 & 0.32 & 0.34 & 0.32 & 0.32 & 0.32 & 0.32 & 0.31 & 0.30 & 0.31 & 0.32 & 0.30 & 0.32 & 0.31 \\
\hline $\mathrm{Cr}_{2} \mathrm{O}_{3}$ & 0.52 & 0.70 & 0.72 & 0.65 & 0.65 & 0.69 & 0.63 & 0.67 & 0.68 & 0.67 & 0.70 & 0.68 & 0.68 & 0.68 & 0.68 & 0.67 & 0.68 \\
\hline $\mathrm{F}$ & $<0.01$ & NA & NA & NA & NA & NA & NA & NA & NA & NA & NA & NA & NA & NA & NA & NA & NA \\
\hline $\mathrm{Fe}_{2} \mathrm{O}_{3}$ & 0.90 & 0.95 & 1.00 & 0.89 & 0.89 & 0.94 & 0.89 & 0.92 & 0.96 & 0.92 & 0.97 & 1.01 & 0.94 & 0.91 & 0.92 & 0.91 & 0.92 \\
\hline I & 0.10 & 0.04 & 0.04 & 0.03 & 0.03 & 0.03 & 0.03 & 0.03 & 0.03 & 0.03 & 0.03 & 0.02 & 0.03 & 0.02 & 0.03 & 0.03 & 0.03 \\
\hline $\mathrm{K}_{2} \mathrm{O}$ & 0.51 & 0.58 & 0.60 & 0.57 & 0.59 & 0.60 & 0.57 & 0.58 & 0.59 & 0.59 & 0.59 & 0.57 & 0.57 & 0.58 & 0.58 & 0.60 & 0.58 \\
\hline $\mathrm{Li}_{2} \mathrm{O}$ & $\S$ & $<0.01$ & $<0.01$ & $<0.01$ & $<0.01$ & $<0.01$ & $<0.01$ & $<0.01$ & $<0.01$ & $<0.01$ & $<0.01$ & $<0.01$ & $<0.01$ & $<0.01$ & $<0.01$ & $<0.01$ & $<0.01$ \\
\hline $\mathrm{MgO}$ & 0.90 & 1.08 & 1.04 & 1.13 & 1.21 & 1.05 & 1.15 & 1.06 & 1.09 & 1.07 & 1.03 & 1.09 & 1.01 & 1.00 & 1.09 & 1.06 & 0.98 \\
\hline $\mathrm{Na}_{2} \mathrm{O}$ & 22.91 & 22.27 & 21.10 & 22.82 & 22.97 & 21.41 & 22.89 & 22.29 & 22.21 & 22.08 & 22.12 & 22.41 & 22.68 & 22.33 & 22.45 & 21.90 & 22.67 \\
\hline $\mathrm{P}_{2} \mathrm{O}_{5}$ & $\S$ & 0.02 & 0.00 & 0.02 & 0.02 & 0.02 & 0.02 & 0.02 & 0.01 & 0.01 & 0.02 & 0.02 & 0.02 & 0.02 & $<0.01$ & 0.02 & 0.02 \\
\hline $\mathrm{SiO}_{2}$ & 34.72 & 35.91 & 36.22 & 36.44 & 36.28 & 37.04 & 36.34 & 36.39 & 36.00 & 36.58 & 36.09 & 35.91 & 35.84 & 36.20 & 36.00 & 36.80 & 36.19 \\
\hline $\mathrm{SnO}_{2}$ & 1.00 & 1.28 & 1.38 & 1.04 & 1.01 & 1.05 & 1.14 & 1.02 & 1.16 & 1.01 & 1.11 & 1.11 & 1.12 & 0.98 & 1.13 & 1.00 & 1.04 \\
\hline $\mathrm{SO}_{3}$ & 1.05 & 0.80 & 0.83 & 0.81 & 0.81 & 0.83 & 0.81 & 0.82 & 0.79 & 0.84 & 0.80 & 0.80 & 0.81 & 0.83 & 0.80 & 0.82 & 0.79 \\
\hline $\mathrm{TiO}_{2}$ & $\S$ & 0.12 & 0.13 & 0.11 & 0.11 & 0.12 & 0.11 & 0.12 & 0.12 & 0.12 & 0.12 & 0.13 & 0.12 & 0.12 & 0.13 & 0.12 & 0.11 \\
\hline $\mathrm{V}_{2} \mathrm{O}_{5}$ & 0.97 & 1.04 & 1.11 & 1.03 & 1.00 & 1.07 & 1.01 & 1.08 & 1.11 & 1.08 & 1.13 & 1.12 & 1.13 & 1.14 & 1.16 & 1.14 & 1.14 \\
\hline $\mathrm{ZnO}$ & 2.98 & 2.82 & 2.97 & 2.61 & 2.59 & 2.79 & 2.56 & 2.76 & 2.83 & 2.76 & 2.86 & 2.79 & 2.75 & 2.75 & 2.76 & 2.71 & 2.72 \\
\hline $\mathrm{ZrO}_{2}$ & 2.98 & 3.14 & 3.33 & 2.74 & 2.71 & 2.86 & 2.77 & 2.88 & 3.08 & 2.90 & 3.02 & 2.99 & 2.99 & 2.86 & 2.99 & 2.79 & 2.84 \\
\hline Sum & 100.00 & 100.00 & 100.00 & 100.00 & 100.00 & 100.00 & 100.00 & 100.00 & 100.00 & 100.00 & 100.00 & 100.00 & 100.00 & 100.00 & 100.00 & 100.00 & 100.00 \\
\hline
\end{tabular}

* - Target values calculated based on simple well-stirred tank model

NA - Not analyzed by XRF; NC - Not calculated

$\S-$ Not a target constituent 
Table 5.4. XRF Analyzed Compositions for LAWA DM100 Discharged Glass Samples (wt\%) (continued).

\begin{tabular}{|c|c|c|c|c|c|c|c|c|c|}
\hline Test & \multicolumn{9}{|c|}{ A4 } \\
\hline Glass (kg) & - & 1414.30 & 1448.04 & 1467.48 & 1490.22 & 1513.42 & 1525.82 & 1206 & 1526 \\
\hline Element & Target & $\begin{array}{c}\text { EWV-G- } \\
133 A\end{array}$ & $\begin{array}{c}\text { EWV-G- } \\
133 C\end{array}$ & $\begin{array}{c}\text { EWV-G- } \\
135 B\end{array}$ & $\begin{array}{c}\text { EWV-G- } \\
136 B\end{array}$ & $\begin{array}{c}\text { EWV-G- } \\
141 \mathrm{~A}\end{array}$ & $\begin{array}{c}\text { EWV-G- } \\
143 A\end{array}$ & Avg. & \%Dev. \\
\hline $\mathrm{Al}_{2} \mathrm{O}_{3}$ & 10.61 & 10.48 & 10.63 & 10.53 & 10.66 & 10.39 & 10.61 & 10.50 & -0.98 \\
\hline $\mathrm{B}_{2} \mathrm{O}_{3} *$ & 12.74 & 12.74 & 12.74 & 12.74 & 12.74 & 12.74 & 12.74 & 12.74 & NC \\
\hline $\mathrm{CaO}$ & 6.46 & 5.69 & 5.66 & 5.86 & 5.71 & 5.97 & 5.76 & 5.81 & -9.98 \\
\hline $\mathrm{Cl}$ & 0.65 & 0.31 & 0.31 & 0.33 & 0.32 & 0.33 & 0.32 & 0.32 & $\mathrm{NC}$ \\
\hline $\mathrm{Cr}_{2} \mathrm{O}_{3}$ & 0.52 & 0.67 & 0.67 & 0.69 & 0.66 & 0.71 & 0.69 & 0.68 & $\mathrm{NC}$ \\
\hline $\mathrm{F}$ & $<0.01$ & $\mathrm{NA}$ & NA & $\mathrm{NA}$ & $\mathrm{NA}$ & $\mathrm{NA}$ & NA & $\mathrm{NC}$ & $\mathrm{NC}$ \\
\hline $\mathrm{Fe}_{2} \mathrm{O}_{3}$ & 0.90 & 0.90 & 0.89 & 0.93 & 0.89 & 0.97 & 0.94 & 0.93 & NC \\
\hline I & 0.10 & 0.02 & 0.03 & 0.03 & 0.02 & 0.03 & 0.03 & 0.03 & NC \\
\hline $\mathrm{K}_{2} \mathrm{O}$ & 0.51 & 0.60 & 0.60 & 0.60 & 0.59 & 0.59 & 0.59 & 0.59 & $\mathrm{NC}$ \\
\hline $\mathrm{Li}_{2} \mathrm{O}^{*}$ & $\S$ & $<0.01$ & $<0.01$ & $<0.01$ & $<0.01$ & $<0.01$ & $<0.01$ & $<0.01$ & $\mathrm{NC}$ \\
\hline $\mathrm{MgO}$ & 0.90 & 1.05 & 1.06 & 1.00 & 1.09 & 1.01 & 1.00 & 1.04 & NC \\
\hline $\mathrm{Na}_{2} \mathrm{O}$ & 22.91 & 22.62 & 22.32 & 21.76 & 22.66 & 21.89 & 22.57 & 22.31 & -2.61 \\
\hline $\mathrm{P}_{2} \mathrm{O}_{5}$ & $\S$ & $<0.01$ & 0.02 & 0.02 & 0.03 & 0.02 & 0.02 & 0.02 & $\mathrm{NC}$ \\
\hline $\mathrm{SiO}_{2}$ & 34.72 & 36.46 & 36.52 & 36.49 & 36.38 & 36.05 & 35.93 & 36.24 & 4.38 \\
\hline $\mathrm{SnO}_{2}$ & 1.00 & 1.01 & 1.09 & 1.12 & 0.91 & 1.18 & 1.10 & 1.07 & 6.68 \\
\hline $\mathrm{SO}_{3}$ & 1.05 & 0.84 & 0.81 & 0.84 & 0.84 & 0.85 & 0.85 & 0.82 & $\mathrm{NC}$ \\
\hline $\mathrm{TiO}_{2}$ & $\S$ & 0.12 & 0.11 & 0.12 & 0.12 & 0.12 & 0.13 & 0.12 & $\mathrm{NC}$ \\
\hline $\mathrm{V}_{2} \mathrm{O}_{5}$ & 0.97 & 1.11 & 1.11 & 1.14 & 1.10 & 1.16 & 1.12 & 1.12 & NC \\
\hline $\mathrm{ZnO}$ & 2.98 & 2.64 & 2.64 & 2.80 & 2.65 & 2.86 & 2.72 & 2.75 & -7.88 \\
\hline $\mathrm{ZrO}_{2}$ & 2.98 & 2.75 & 2.80 & 3.01 & 2.64 & 3.11 & 2.91 & 2.91 & -2.47 \\
\hline Sum & 100.00 & 100.00 & 100.00 & 100.00 & 100.00 & 100.00 & 100.00 & 100.00 & $\mathrm{NC}$ \\
\hline
\end{tabular}

* - Target values calculated based on simple well-stirred tank model NA - Not analyzed by XRF; NC - Not calculated $\S-$ Not a target constituent 
Table 5.5. Comparison of XRF and DCP Analysis of Melter Glass Samples (wt\%).

\begin{tabular}{|c|c|c|c|c|c|c|c|c|c|c|c|c|}
\hline \multirow{4}{*}{$\begin{array}{l}\text { Waste } \\
\text { Test }\end{array}$} & \multicolumn{6}{|c|}{ LAW Envelope B } & \multicolumn{6}{|c|}{ LAW Envelope A } \\
\hline & \multicolumn{3}{|c|}{ B3 } & \multirow{2}{*}{\multicolumn{3}{|c|}{ B4 }} & \multirow{2}{*}{\multicolumn{3}{|c|}{$\begin{array}{c}\text { A3 } \\
\text { EWV-G-89B }\end{array}$}} & \multirow{2}{*}{\multicolumn{3}{|c|}{\begin{tabular}{|c|} 
A4 \\
EWV-G-143A
\end{tabular}}} \\
\hline & \multicolumn{3}{|c|}{ DWV-G-123C } & & & & & & & & & \\
\hline & Target & XRF & DCP & Target & XRF & DCP & Target & XRF & DCP & Target & XRF & DCP \\
\hline $\mathrm{Al}_{2} \mathrm{O}_{3}$ & 10.06 & 9.74 & 9.62 & 10.05 & 9.34 & 9.64 & 10.62 & 10.62 & 10.84 & 10.61 & 10.61 & 10.73 \\
\hline $\mathrm{B}_{2} \mathrm{O}_{3}$ & 10.91 & 10.91* & 10.78 & 10.90 & $10.90^{*}$ & 10.63 & 12.75 & $12.75 *$ & 12.75 & 12.74 & $12.74 *$ & 12.46 \\
\hline $\mathrm{CaO}$ & 10.11 & 9.53 & 8.92 & 10.10 & 9.74 & 8.97 & 6.47 & 5.71 & 5.84 & 6.46 & 5.76 & 5.93 \\
\hline $\mathrm{Cl}$ & 0.01 & 0.01 & NA & 0.01 & 0.01 & NA & 0.65 & 0.34 & NA & 0.65 & 0.32 & NA \\
\hline $\mathrm{Cr}_{2} \mathrm{O}_{3}$ & 0.11 & 0.20 & 0.19 & 0.11 & 0.21 & 0.19 & 0.52 & 0.70 & 0.67 & 0.52 & 0.69 & 0.68 \\
\hline $\mathrm{F}$ & 0.07 & NA & NA & 0.07 & NA & NA & $<0.01$ & NA & NA & $<0.01$ & NA & NA \\
\hline $\mathrm{Fe}_{2} \mathrm{O}_{3}$ & 1.14 & 1.31 & 1.35 & 1.13 & 1.28 & 1.32 & 0.90 & 0.95 & 0.95 & 0.90 & 0.94 & 1.02 \\
\hline I & 0.10 & 0.03 & NA & 0.10 & 0.03 & NA & 0.10 & 0.03 & NA & 0.10 & 0.03 & NA \\
\hline $\mathrm{K}_{2} \mathrm{O}$ & 0.40 & 0.59 & 0.61 & 0.40 & 0.57 & 0.56 & 0.51 & 0.58 & 0.65 & 0.51 & 0.59 & 0.67 \\
\hline $\mathrm{Li}_{2} \mathrm{O}$ & 3.52 & $3.51^{*}$ & 3.44 & 3.51 & $3.51^{*}$ & 3.41 & $\S$ & $<0.01$ & 0.12 & $\S$ & $<0.01$ & 0.07 \\
\hline $\mathrm{MgO}$ & 1.14 & 1.16 & 1.30 & 1.13 & 1.08 & 1.24 & 0.90 & 1.00 & 1.03 & 0.90 & 1.00 & 1.18 \\
\hline $\mathrm{Na}_{2} \mathrm{O}$ & 9.96 & 10.17 & 9.30 & 9.95 & 10.17 & 9.24 & 22.93 & 23.02 & 20.34 & 22.91 & 22.57 & 20.31 \\
\hline $\mathrm{P}_{2} \mathrm{O}_{5}$ & 0.03 & 0.08 & 0.17 & 0.03 & 0.08 & 0.19 & $\S$ & 0.02 & 0.06 & $\S$ & 0.02 & 0.11 \\
\hline $\mathrm{SiO}_{2}$ & 42.73 & 42.90 & 42.57 & 42.69 & 43.05 & 41.34 & 34.75 & 35.80 & 33.90 & 34.72 & 35.93 & 34.56 \\
\hline $\mathrm{SnO}_{2}$ & $\S$ & $<0.01$ & 0.03 & $\S$ & $<0.01$ & 0.03 & 1.00 & 1.05 & 1.15 & 1.00 & 1.10 & 1.17 \\
\hline $\mathrm{SO}_{3}$ & 1.49 & 1.17 & NA & 1.59 & 1.14 & NA & 0.95 & 0.80 & NA & 1.05 & 0.85 & NA \\
\hline $\mathrm{TiO}_{2}$ & $\S$ & 0.24 & 0.25 & $\S$ & 0.22 & 0.23 & $\S$ & 0.12 & 0.14 & $\S$ & 0.13 & 0.14 \\
\hline $\mathrm{V}_{2} \mathrm{O}_{5}$ & 1.23 & 1.38 & 1.29 & 1.22 & 1.43 & 1.27 & 0.97 & 0.83 & 0.79 & 0.97 & 1.12 & 1.09 \\
\hline $\mathrm{ZnO}$ & 3.51 & 3.35 & 3.49 & 3.50 & 3.47 & 3.51 & 2.99 & 2.82 & 3.08 & 2.98 & 2.72 & 2.98 \\
\hline $\mathrm{ZrO}_{2}$ & 3.51 & 3.72 & \begin{tabular}{|l|}
3.36 \\
\end{tabular} & 3.50 & 3.77 & 3.32 & 2.99 & 2.85 & 2.82 & 2.98 & 2.91 & 2.86 \\
\hline Sum & 100.00 & 100.00 & 96.67 & 100.00 & 100.00 & 95.09 & 100.00 & 100.00 & 95.13 & 100.00 & 100.00 & 95.96 \\
\hline
\end{tabular}


Table 5.6. Dip samples and Presence of Sulfate Layer During DM100 Melter Tests.

\begin{tabular}{|c|c|c|c|c|c|c|}
\hline $\begin{array}{l}\text { Waste } \\
\text { Type }\end{array}$ & Test & $\begin{array}{c}\text { Sampling } \\
\text { Date }\end{array}$ & Sample Name & $\begin{array}{c}\text { Target } \mathrm{SO}_{3} \\
\text { (wt\%) }\end{array}$ & $\begin{array}{c}\text { Glass Discharged } \\
\text { (kg) }\end{array}$ & $\begin{array}{c}\text { Secondary } \\
\text { Sulfate Phase }\end{array}$ \\
\hline \multirow{9}{*}{ LAWB } & \multirow{6}{*}{ B3 } & \multirow{3}{*}{ 9/21/05 } & DWV-D-101A & \multirow{6}{*}{1.50} & \multirow{3}{*}{510.24} & No \\
\hline & & & DWV-D-101B & & & No \\
\hline & & & DWV-D-101C & & & No \\
\hline & & & DWV-D-123A & & \multirow{3}{*}{803.2} & No \\
\hline & & 9/22/05 & DWV-D-123B & & & No \\
\hline & & & DWV-D-123C & & & No \\
\hline & \multirow{3}{*}{ B4 } & \multirow{3}{*}{ 9/25/05 } & EWV-D-11A & \multirow{3}{*}{1.60} & \multirow{3}{*}{1538.8} & No \\
\hline & & & EWV-D-11B & & & No \\
\hline & & & EWV-D-11C & & & No \\
\hline \multirow{7}{*}{ LAWA } & \multirow{4}{*}{ A3 } & $10 / 06 / 05$ & EWV-D-52A & \multirow{4}{*}{0.95} & 278.04 & No \\
\hline & & & EWV-D-89A & & \multirow{3}{*}{787.20} & No \\
\hline & & 10/08/05 & EWV-D-89B & & & No \\
\hline & & & EWV-D-89C & & & No \\
\hline & \multirow{3}{*}{ A4 } & \multirow{3}{*}{ 10/11/05 } & EWV-D-143A & \multirow{3}{*}{1.05} & \multirow{3}{*}{1525.82} & No \\
\hline & & & EWV-D-143B & & & No \\
\hline & & & EWV-D-143C & & & No \\
\hline
\end{tabular}


Table 5.7. Results of PCT $\left(7\right.$ days at $\left.90^{\circ} \mathrm{C}\right)$ and VHT (at $200^{\circ} \mathrm{C}$ for 24 Days $\left.\left(\mathrm{g} / \mathrm{m}^{2} / \mathrm{day}\right)\right)$ for LAW Envelope A Crucible and DM100 Melter Glasses.

\begin{tabular}{|c|c|c|c|c|c|c|c|c|c|c|}
\hline \multirow{2}{*}{$\begin{array}{l}\text { Glass Sample } \\
\text { Treatment description }\end{array}$} & \multicolumn{3}{|c|}{$\begin{array}{c}\text { LAWA187 } \\
\text { Crucible melt }\end{array}$} & \multicolumn{3}{|c|}{$\begin{array}{l}\text { EWV-G-89B } \\
\text { Melter Glass }\end{array}$} & \multicolumn{2}{|c|}{$\begin{array}{l}\text { EWV-G-93B } \\
\text { Melter Glass }\end{array}$} & \multirow{2}{*}{$\begin{array}{c}\text { EWV-G-108B } \\
\text { Melter Glass } \\
\text { As melted }\end{array}$} & \multirow{2}{*}{$\begin{array}{l}\text { WTP } \\
\text { Contract } \\
\text { Limit }\end{array}$} \\
\hline & \multicolumn{2}{|c|}{ As melted } & CCC & \multicolumn{2}{|c|}{ As melted } & CCC & As melted & CCC & & \\
\hline \multicolumn{11}{|c|}{ 7-Day PCT, Stainless Steel Vessel; S/V=2000m ${ }^{-1}$} \\
\hline \multicolumn{11}{|c|}{ Concentration in ppm } \\
\hline $\mathrm{B}$ & \multicolumn{2}{|c|}{136.00} & 81.73 & \multicolumn{2}{|c|}{84.06} & 89.04 & - & - & - & - \\
\hline $\mathrm{Na}$ & \multicolumn{2}{|c|}{499.00} & 286.60 & \multicolumn{2}{|c|}{323.70} & 290.9 & - & - & - & - \\
\hline Si & \multicolumn{2}{|c|}{79.87} & 58.69 & \multicolumn{2}{|c|}{63.07} & 58.55 & - & - & - & - \\
\hline \multicolumn{11}{|l|}{ 7-Day PCT Normalized Concentrations (g/L) } \\
\hline $\mathrm{B}$ & \multicolumn{2}{|c|}{3.42} & 2.06 & \multicolumn{2}{|c|}{2.12} & 2.25 & - & - & - & - \\
\hline $\mathrm{Na}$ & \multicolumn{2}{|c|}{2.92} & 1.68 & \multicolumn{2}{|c|}{1.90} & 1.70 & - & - & - & - \\
\hline Si & \multicolumn{2}{|c|}{0.49} & 0.36 & \multicolumn{2}{|c|}{0.39} & 0.36 & - & - & - & - \\
\hline $\mathrm{pH}$ & \multicolumn{2}{|c|}{11.68} & 11.55 & \multicolumn{2}{|c|}{11.55} & 11.53 & - & - & - & - \\
\hline \multicolumn{11}{|l|}{ 7-Day PCT Normalized Mass Loss (g/m²) } \\
\hline B & \multicolumn{2}{|c|}{1.71} & 1.03 & \multicolumn{2}{|c|}{1.06} & 1.12 & - & - & - & $<2.0$ \\
\hline $\mathrm{Na}$ & \multicolumn{2}{|c|}{1.46} & 0.84 & \multicolumn{2}{|c|}{0.95} & 0.85 & - & - & - & $<2.0$ \\
\hline Si & \multicolumn{2}{|c|}{0.25} & 0.18 & \multicolumn{2}{|c|}{0.19} & 0.18 & - & - & - & $<2.0$ \\
\hline 7-Day PCT Normalized Loss Rate $\left(\mathrm{g} / \mathrm{m}^{2} / \mathrm{d}\right.$ & & & & & & & & & & \\
\hline B & 0. & & 0.15 & & & 0.16 & - & - & - & - \\
\hline $\mathrm{Na}$ & 0.2 & & 0.12 & & & 0.12 & - & - & - & - \\
\hline $\mathrm{Si}$ & 0.0 & & 0.03 & & & 0.03 & - & - & - & - \\
\hline VHT Alteration (24 days at $200{ }^{\circ} \mathrm{C}$ ) & & & & & & & & & & \\
\hline Duration (days) & 23.8 & 26.4 & - & 24.0 & 26.4 & 26.4 & 26.4 & 26.4 & 26.4 & - \\
\hline Alteration depth $(\mu \mathrm{m})$ & 230 & 334 & - & 736 & 906 & 230 & 719 & 223 & 291 & - \\
\hline $\begin{array}{l}\text { Alteration Rate }\left(\mathrm{g} / \mathrm{m}^{2} / \mathrm{d}\right) \text { calculated using } \\
\text { measured density of } 2.626 \mathrm{~g} / \mathrm{cc}\end{array}$ & 25 & 33 & - & 81 & 90 & 23 & 71 & 22 & 29 & $<50.0$ \\
\hline
\end{tabular}

- Empty data field 
Table 5.8. Comparison of XRF Analyzed Composition for Melter Glass Sample Before and After Canister Cooling Heat Treatment (wt\%).

\begin{tabular}{|c|c|c|c|}
\hline- & \multicolumn{3}{|c|}{ Melter Glass, EWV-G-89B } \\
\hline Constituent & Target & Analyzed & $\begin{array}{c}\text { Analyzed after } \\
\text { Canister Cooling }\end{array}$ \\
\hline $\mathrm{Al}_{2} \mathrm{O}_{3}$ & 10.62 & 10.62 & 10.88 \\
\hline $\mathrm{B}_{2} \mathrm{O}_{3}{ }^{*}$ & 12.75 & 12.75 & 12.75 \\
\hline $\mathrm{CaO}$ & 6.47 & 5.71 & 5.60 \\
\hline $\mathrm{Cl}$ & 0.65 & 0.34 & 0.28 \\
\hline $\mathrm{Cr}_{2} \mathrm{O}_{3}$ & 0.52 & 0.70 & 0.69 \\
\hline $\mathrm{F}$ & $<0.01$ & NA & NA \\
\hline $\mathrm{Fe}_{2} \mathrm{O}_{3}$ & 0.90 & 0.95 & 0.89 \\
\hline $\mathrm{I}$ & 0.10 & 0.03 & 0.03 \\
\hline $\mathrm{K}_{2} \mathrm{O}$ & 0.51 & 0.58 & 0.57 \\
\hline $\mathrm{MgO}_{2}$ & 0.90 & 1.00 & 0.85 \\
\hline $\mathrm{Na}_{2} \mathrm{O}$ & 22.93 & 23.02 & 22.66 \\
\hline $\mathrm{P}_{2} \mathrm{O}_{5}$ & $\S$ & 0.02 & 0.03 \\
\hline $\mathrm{SiO}_{2}$ & 34.75 & 35.80 & 36.12 \\
\hline $\mathrm{SnO}_{2}$ & 1.00 & 1.05 & 1.23 \\
\hline $\mathrm{SO}_{3}$ & 0.95 & 0.80 & 0.76 \\
\hline $\mathrm{TiO}_{2}$ & $\S$ & 0.12 & 0.13 \\
\hline $\mathrm{V}_{2} \mathrm{O}_{5}$ & 0.97 & 0.83 & 0.81 \\
\hline $\mathrm{ZnO}_{2 n}$ & 2.99 & 2.82 & 2.75 \\
\hline $\mathrm{ZrO}_{2}$ & 2.99 & 2.85 & 2.97 \\
\hline $\mathrm{Sum}$ & 100.0 & 100.0 & 100.0 \\
\hline
\end{tabular}

* Target value

NA - Not analyzed by XRF

$\S$ - Not a target constituent 
Table 5.9. Results of PCT (7 days at $90^{\circ} \mathrm{C}$ ) and VHT (at $200^{\circ} \mathrm{C}$ for 24 Days $\left(\mathrm{g} / \mathrm{m}^{2} /\right.$ day)) for LAW Envelope B Crucible and DM100 Melter Glasses.

\begin{tabular}{|c|c|c|c|}
\hline Glass Sample & $\begin{array}{c}\text { LAWB99 } \\
\text { Crucible melt }\end{array}$ & $\begin{array}{l}\text { DWV-G-123C } \\
\text { Melter Glass }\end{array}$ & $\begin{array}{l}\text { WTP Contract } \\
\text { Limit }\end{array}$ \\
\hline \multicolumn{4}{|c|}{ 7-Day PCT, Stainless Steel Vessel; S/V=2000m } \\
\hline \multicolumn{4}{|l|}{ Concentration in ppm } \\
\hline $\mathrm{B}$ & 8.09 & 6.13 & - \\
\hline $\mathrm{Na}$ & 30.70 & 24.49 & - \\
\hline Si & 28.82 & 24.44 & - \\
\hline \multicolumn{4}{|c|}{ 7-Day PCT Normalized Concentrations (g/L) } \\
\hline $\mathrm{B}$ & 0.24 & 0.18 & - \\
\hline $\mathrm{Na}$ & 0.41 & 0.33 & - \\
\hline Si & 0.14 & 0.12 & - \\
\hline $\mathrm{pH}$ & 10.65 & 11.65 & - \\
\hline \multicolumn{4}{|c|}{ 7-Day PCT Normalized Mass Loss (g/m²) } \\
\hline $\mathrm{B}$ & 0.12 & 0.09 & $<2.0$ \\
\hline $\mathrm{Na}$ & 0.21 & 0.17 & $<2.0$ \\
\hline Si & 0.07 & 0.06 & $<2.0$ \\
\hline \multicolumn{4}{|c|}{ 7-Day PCT Normalized Loss Rate (g/m²/d) } \\
\hline $\mathrm{B}$ & 0.02 & 0.01 & - \\
\hline $\mathrm{Na}$ & 0.03 & 0.02 & - \\
\hline Si & 0.01 & 0.01 & - \\
\hline \multicolumn{4}{|l|}{ VHT Alteration ( 24 days at $200^{\circ} \mathrm{C}$ ) } \\
\hline Duration (days) & 24.0 & 24.0 & - \\
\hline Alteration depth $(\mu \mathrm{m})$ & 135 & 198 & - \\
\hline $\begin{array}{l}\text { Alteration Rate }\left(\mathrm{g} / \mathrm{m}^{2} / \mathrm{d}\right) \text { calculated } \\
\text { using measured density of } 2.658 \mathrm{~g} / \mathrm{cc}\end{array}$ & 15 & 22 & $<50.0$ \\
\hline
\end{tabular}

- Empty data field 
The Catholic University of America Vitreous State Laboratory
ORP-56322, Rev. 0 LAW Envelope A and B Glass Formulations Testing to Increase Waste Loading Final Report, VSL-06R6900-1, Rev. 0

Table 6.1. Results from LAW B Melter Off-Gas Emission Samples.

\begin{tabular}{|c|c|c|c|c|c|c|c|c|c|}
\hline & \multicolumn{4}{|c|}{ Test B3 } & \multicolumn{4}{|c|}{ Test B4 } \\
\hline & & \multicolumn{4}{|c|}{$\begin{array}{c}\text { 09/22/05 10:52 - 11:52 } \\
\text { 105\% Isokinetic, } 12.6 \% \text { Moisture }\end{array}$} & \multicolumn{4}{|c|}{$\begin{array}{c}\text { 09/24/05 18:12 - 18:52 } \\
\text { 105\% Isokinetic, } 14.7 \% \text { Moisture }\end{array}$} \\
\hline & & $\begin{array}{c}\text { Feed } \\
\text { Rate }^{\#} \\
(\mathrm{mg} / \mathrm{min})\end{array}$ & $\begin{array}{c}\text { Emission } \\
\text { Rate } \\
\text { (mg/min) }\end{array}$ & $\%$ Feed & $\mathrm{DF}$ & $\begin{array}{c}\text { Feed Rate } \\
(\mathrm{mg} / \mathrm{min})\end{array}$ & $\begin{array}{c}\text { Emission } \\
\text { Rate } \\
\text { (mg/min) }\end{array}$ & $\%$ Feed & $\mathrm{DF}$ \\
\hline \multirow{19}{*}{ 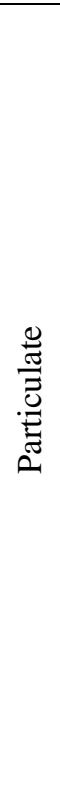 } & Total $^{\$}$ & 188667 & 174.8 & 0.09 & 1079 & 230617 & 208.8 & 0.09 & 1104 \\
\hline & $\mathrm{Al}$ & 8981 & 1.23 & 0.01 & 7285.1 & 10966 & 1.15 & 0.01 & 9526.1 \\
\hline & B & 5714 & 3.98 & 0.07 & 1436.5 & 6977 & 3.42 & 0.05 & 2040.8 \\
\hline & $\mathrm{Ca}$ & 12195 & 3.19 & 0.03 & 3820.6 & 14890 & 2.63 & 0.02 & 5654.6 \\
\hline & $\mathrm{Cl}^{*}$ & 17 & 3.58 & 21.1 & 4.75 & 21 & 3.66 & 17.0 & 5.7 \\
\hline & $\mathrm{Cr}$ & 127 & 0.72 & 0.57 & 175.3 & 155 & 0.83 & 0.54 & 186.7 \\
\hline & $\mathrm{F}^{*}$ & 118 & 0.63 & 1.0 & 187 & 144 & 0.16 & 0.11 & 900 \\
\hline & $\mathrm{Fe}$ & 1345 & 0.34 & 0.03 & 3968.7 & 1630 & 0.26 & 0.02 & 6239.7 \\
\hline & $I^{*}$ & 169 & $<0.10$ & $<0.01$ & $>1690$ & 206 & $<0.10$ & $<0.05$ & $>2060$ \\
\hline & $\mathrm{K}$ & 560 & 5.39 & 0.96 & 103.9 & 685 & 6.46 & 0.94 & 106.0 \\
\hline & $\mathrm{Li}$ & 2759 & 2.27 & 0.08 & 1214.5 & 3363 & 2.66 & 0.08 & 1263.6 \\
\hline & $\mathrm{Mg}$ & 1160 & $<0.10$ & $<0.01$ & $>11600$ & 1405 & $<0.10$ & $<0.01$ & $>14050$ \\
\hline & $\mathrm{Na}$ & 12470 & 27.1 & 0.22 & 461.0 & 15226 & 32.4 & 0.21 & 470.3 \\
\hline & $\mathrm{P}$ & 22 & $<0.10$ & $<0.05$ & $>220$ & 27 & $<0.10$ & $<0.37$ & $>270$ \\
\hline & S* & 1014 & 27.0 & 2.66 & 37.6 & 1322 & 37.9 & 2.87 & 34.9 \\
\hline & $\mathrm{Si}$ & 33707 & 6.59 & 0.02 & 5112.1 & 41159 & 5.29 & 0.01 & 7782.4 \\
\hline & $\mathrm{V}$ & 581 & 1.07 & 0.18 & 541.1 & 705 & 0.87 & 0.12 & 806.8 \\
\hline & $\mathrm{Zn}$ & 4759 & 0.98 & 0.02 & 4851.3 & 5799 & 0.90 & 0.02 & 6434.2 \\
\hline & $\mathrm{Zr}$ & 4385 & 0.35 & 0.01 & 12358.8 & 5344 & 0.33 & 0.01 & 16258.3 \\
\hline \multirow{5}{*}{ 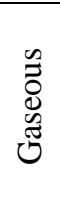 } & B & 5714 & 30.6 & 0.53 & 187.0 & 6977 & 36.1 & 0.52 & 193.5 \\
\hline & $\mathrm{Cl}$ & 17 & 18.3 & 108.37 & 0.9 & 21 & 15.4 & 74.73 & 1.3 \\
\hline & $\mathrm{F}$ & 118 & 42.6 & 36.08 & 2.8 & 144 & 41.1 & 28.48 & 3.5 \\
\hline & $\mathrm{I}$ & 169 & 109 & 64.78 & 1.5 & 206 & 135 & 65.54 & 1.5 \\
\hline & $\mathrm{S}$ & 1014 & 124 & 12.23 & 8.2 & 1322 & 256 & 19.33 & 5.2 \\
\hline
\end{tabular}

\$ - From gravimetric analysis of filters and particulate nitric acid rinses.

* - Based on analysis of water dissolution of filter particulate and acid dissolution of front-half rinse.

\# -Feed rate calculated from target composition and production rate.

@ - Based on analyzed, not target value. 
The Catholic University of America Vitreous State Laboratory
ORP-56322, Rev. 0 LAW Envelope A and B Glass Formulations Testing to Increase Waste Loading Final Report, VSL-06R6900-1, Rev. 0

Table 6.2. Results from LAW A Melter Off-Gas Emission Samples.

\begin{tabular}{|c|c|c|c|c|c|c|c|c|c|}
\hline & \multicolumn{4}{|c|}{ Test A3 } & \multicolumn{4}{|c|}{ Test A4 } \\
\hline & & \multicolumn{4}{|c|}{$\begin{array}{c}\text { 10/08/05 17:30 - 17:50 } \\
\text { 107\% Isokinetic, 13.2\% Moisture }\end{array}$} & \multicolumn{4}{|c|}{$\begin{array}{c}\text { 10/10/05 18:36 - 18:56 } \\
\text { 109\% Isokinetic, } 16.0 \% \text { Moisture }\end{array}$} \\
\hline & & $\begin{array}{c}\text { Feed Rate }^{\#} \\
(\mathrm{mg} / \mathrm{min})\end{array}$ & $\begin{array}{c}\text { Emission } \\
\text { Rate } \\
\text { (mg/min) }\end{array}$ & \% Feed & $\mathrm{DF}$ & $\begin{array}{l}\text { Feed Rate } \\
(\mathrm{mg} / \mathrm{min})\end{array}$ & $\begin{array}{c}\text { Emission } \\
\text { Rate } \\
\text { (mg/min) }\end{array}$ & \% Feed & DF \\
\hline \multirow{20}{*}{ 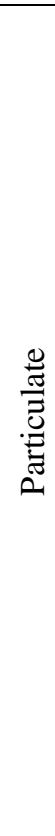 } & Total $^{\$}$ & 200483 & 2388 & 1.19 & 84.0 & 245033 & 2620 & 1.07 & 93.5 \\
\hline & $\mathrm{Al}$ & 9481 & 35.1 & 0.37 & 270.1 & 11577 & 38.3 & 0.33 & 302.7 \\
\hline & B & 6677 & 125 & 1.87 & 53.5 & 8155 & 123 & 1.51 & 66.2 \\
\hline & $\mathrm{Ca}$ & 7804 & 21.1 & 0.27 & 369.7 & 9524 & 21.8 & 0.23 & 436.2 \\
\hline & $\mathrm{Cl}^{*}$ & 1097 & 506 & 47.7 & 2.2 & 1341 & 538 & 40.1 & 2.5 \\
\hline & $\mathrm{Cr}$ & 600 & 9.91 & 1.65 & 60.6 & 734 & 13.0 & 1.77 & 56.5 \\
\hline & $\mathrm{F}^{*}$ & 0 & 0.93 & $\mathrm{NC}$ & $\mathrm{NC}$ & 0 & 0.23 & $\mathrm{NC}$ & $\mathrm{NC}$ \\
\hline & $\mathrm{Fe}$ & 1062 & 2.16 & 0.20 & 491.5 & 1298 & 2.84 & 0.22 & 456.7 \\
\hline & $\mathrm{I}^{*}$ & 169 & 7.54 & 4.46 & 22.4 & 206 & 6.0 & 2.91 & 34.3 \\
\hline & $\mathrm{K}$ & 714 & 60.9 & 8.53 & 11.7 & 873 & 71.7 & 8.21 & 12.2 \\
\hline & $\mathrm{Li}$ & 0 & 0.27 & $\mathrm{NC}$ & $\mathrm{NC}$ & 0 & 0.14 & $\mathrm{NC}$ & $\mathrm{NC}$ \\
\hline & $\mathrm{Mg}$ & 916 & 0.58 & 0.06 & 1585.0 & 1119 & 0.57 & 0.05 & 1966.3 \\
\hline & $\mathrm{Na}$ & 28709 & 602 & 2.10 & 47.7 & 35058 & 642 & 1.83 & 54.6 \\
\hline & $\mathrm{P}$ & 0 & $<0.10$ & $\mathrm{NC}$ & $\mathrm{NC}$ & 0 & $<0.10$ & $\mathrm{NC}$ & $\mathrm{NC}$ \\
\hline & $\mathrm{S}^{*}$ & 642 & 46.4 & 7.35 & 13.6 & 868 & 77.7 & 9.02 & 11.1 \\
\hline & $\mathrm{Si}$ & 27412 & 53.1 & 0.19 & 516.6 & 33475 & 53.3 & 0.16 & 628.0 \\
\hline & Sn & 1329 & $<0.10$ & $<0.01$ & $>13290$ & 1625 & $<0.10$ & $<0.01$ & $>1625$ \\
\hline & $\mathrm{V}$ & 458 & 8.97 & 1.96 & 51.1 & 560 & 12.0 & 2.14 & 46.8 \\
\hline & $\mathrm{Zn}$ & 4054 & 26.9 & 0.66 & 150.4 & 4938 & 25.3 & 0.51 & 195.5 \\
\hline & $\mathrm{Zr}$ & 3735 & 2.53 & 0.07 & 1476.1 & 4550 & 3.80 & 0.08 & 1196.0 \\
\hline \multirow{5}{*}{$\begin{array}{l}0 \\
0 \\
0 \\
0 \\
0 \\
0\end{array}$} & B & 6677 & 3.48 & 0.05 & 1919.5 & 8155 & 7.80 & 0.10 & 1045.4 \\
\hline & $\mathrm{Cl}$ & 1097 & $<0.10$ & $<0.01$ & $>10970$ & 1341 & $<0.10$ & $<0.01$ & $>13410$ \\
\hline & $\mathrm{F}$ & 0 & $<0.10$ & $\mathrm{NC}$ & $\mathrm{NC}$ & 0 & $<0.10$ & $\mathrm{NC}$ & $\mathrm{NC}$ \\
\hline & I & 169 & 140 & 83.22 & 1.2 & 206 & 127 & 61.76 & 1.6 \\
\hline & $\mathrm{S}$ & 642 & 1.38 & 0.21 & 466.6 & 868 & 1.29 & 0.15 & 672.2 \\
\hline
\end{tabular}

$\$$ - From gravimetric analysis of filters and particulate nitric acid rinses

NC - Not Calculated

* - Based on analysis of water dissolution of filter particulate and acid dissolution of front-half rinse.

\# - Feed rate calculated from target composition and production rate 
The Catholic University of America Vitreous State Laboratory Final Report, VSL-06R6900-1, Rev.

\section{Table 6.3. Average Concentration (ppmv) of Selected Species in Off-Gas Measured by FTIR Spectroscopy during DM100 Tests.}

\begin{tabular}{|c|c|c|c|c|c|c|c|c|}
\hline \multirow{3}{*}{$\begin{array}{c}\text { Test } \\
\text { Analyte }\end{array}$} & \multicolumn{4}{|c|}{ LAW B } & \multicolumn{4}{|c|}{ LAW A } \\
\hline & \multicolumn{2}{|r|}{ B3 } & \multicolumn{2}{|r|}{ B4 } & \multicolumn{2}{|r|}{ A3 } & \multicolumn{2}{|r|}{ A4 } \\
\hline & Avg. & Range & Avg. & Range & Avg. & Range & Avg. & Range \\
\hline $\mathrm{N}_{2} \mathrm{O}$ & 60.0 & $<1.0-258$ & 68.4 & $28.3-304$ & 112 & $3.9-954$ & 127 & $<1.0-840$ \\
\hline $\mathrm{NO}$ & 401 & $1.0-1817$ & 493 & $231-1940$ & 1346 & $86.5-5841$ & 1623 & $29.7-4225$ \\
\hline $\mathrm{NO}_{2}$ & 4.1 & $<1.0-97.0$ & 16.6 & $<1.0-159$ & 124 & $<1.0-1290$ & 200 & $3.1-1769$ \\
\hline $\mathrm{NH}_{3}$ & 17.9 & $<1.0-102$ & 24.4 & $2.1-117$ & 38.6 & $2.6-574$ & 43.1 & $2.7-353$ \\
\hline $\mathrm{H}_{2} \mathrm{O}[\%]$ & 7.0 & $0.0-15.3$ & 8.1 & $2.9-19.8$ & 7.1 & $2.6-22.9$ & 8.3 & $1.8-18.5$ \\
\hline $\mathrm{CO}_{2}$ & 3000 & $<100-17000$ & 4000 & $2000-15000$ & 3000 & $1000-13000$ & 4000 & $<100-11000$ \\
\hline Nitrous Acid & $<1.0$ & NA & $<1.0$ & NA & $<1.0$ & $<1.0-5.4$ & $<1.0$ & $<1.0-5.5$ \\
\hline Nitric Acid & $<1.0$ & NA & $<1.0$ & NA & $<1.0$ & NA & $<1.0$ & NA \\
\hline HCN & $<1.0$ & $<1.0-3.2$ & $<1.0$ & $<1.0-4.0$ & $<1.0$ & $<1.0-2.7$ & $<1.0$ & NA \\
\hline $\mathrm{SO}_{2}$ & 14.6 & $<5.0-65.6$ & 33.0 & $<5.0-99.3$ & $<5.0$ & $\mathrm{NA}$ & $<5.0$ & NA \\
\hline Acetonitrile & 3.7 & $<1.0-111$ & $<1.0$ & NA & 8.1 & $<1.0-66.8$ & 6.9 & $<1.0-526$ \\
\hline $\mathrm{CO}$ & 9.3 & $<1.0-57.1$ & 14.1 & $1.6-63.9$ & 41.2 & $<1.0-254$ & 47.6 & $<1.0-168$ \\
\hline $\mathrm{HCl}$ & $<1.0$ & $<1.0-3.6$ & 4.8 & $<1.0-16.7$ & $<1.0$ & NA & $<1.0$ & NA \\
\hline $\mathrm{HF}$ & 1.1 & $<1.0-6.8$ & 4.0 & $<1.0-28.9$ & $<1.0$ & $<1.0-1.6$ & $<1.0$ & $<1.0-3.5$ \\
\hline
\end{tabular}

NA - Not Applicable 
Table 6.4. Average NOx Fluxes in Off-Gas Measured by FTIR Spectroscopy.

\begin{tabular}{|c|c|c|c|c|c|c|}
\hline \multirow{2}{*}{ Waste } & \multirow{2}{*}{ Test } & \multirow{2}{*}{$\begin{array}{c}\text { Feed } \\
{[\mathrm{mol} / \mathrm{hr}]}\end{array}$} & \multicolumn{3}{|c|}{ Emissions [mol/h] } & \multirow{2}{*}{$\begin{array}{c}\% \text { Feed } \mathrm{NO}_{\mathrm{x}} \text { Emitted as } \\
\text { Nitrogen Oxides }\end{array}$} \\
\hline & & & $\mathrm{N}_{2} \mathrm{O}[\mathrm{mol} / \mathrm{hr}]$ & NO $[\mathrm{mol} / \mathrm{hr}]$ & $\mathrm{NO}_{2}[\mathrm{~mol} / \mathrm{hr}]$ & \\
\hline \multirow{2}{*}{ LAW B } & B3 & 10.5 & 0.6 & 4.2 & $<0.1$ & 45.7 \\
\hline & B4 & 12.7 & 0.7 & 5.2 & 0.2 & 48.0 \\
\hline \multirow{2}{*}{ LAW A } & A3 & 35.2 & 1.3 & 15.7 & 1.4 & 52.0 \\
\hline & A4 & 46.6 & 1.5 & 19.0 & 2.3 & 48.9 \\
\hline
\end{tabular}


Table 6.5. Mass Balances for Sulfur, Iodine, and Chlorine During Select DM100 Tests with LAW Simulants (\% of Feed). (Results for new formulations from the present work (in bold face) are compared to results from previous tests with old formulations).

\begin{tabular}{|c|c|c|c|c|c|c|c|}
\hline Test & Waste & $\begin{array}{c}\text { Glass } \\
\text { Temperature }\end{array}$ & Element & Glass & $\begin{array}{c}\text { Particle } \\
\text { Emissions }\end{array}$ & $\begin{array}{c}\text { Gaseous } \\
\text { Emissions }\end{array}$ & Total \\
\hline \multirow{2}{*}{$\mathrm{SO}_{3}=1.5 \mathrm{wt} \%$} & \multirow{2}{*}{ LAW B2 } & \multirow{2}{*}{$1150^{\circ} \mathrm{C}$} & Sulfur & 76 & 3.9 & 12.2 & 92 \\
\hline & & & Iodine & 30 & $<0.1$ & 65 & 95 \\
\hline \multirow{2}{*}{$\mathrm{SO}_{3}=1.6 \mathrm{wt} \%$} & \multirow{2}{*}{ LAW B2 } & \multirow{2}{*}{$1175^{\circ} \mathrm{C}$} & Sulfur & 72 & 3.4 & 19.3 & 95 \\
\hline & & & Iodine & 30 & $<0.1$ & 66 & 96 \\
\hline \multirow{2}{*}{$\begin{array}{c}\mathrm{SO}_{3}=0.72 \mathrm{wt} \% \\
{[13]}\end{array}$} & \multirow{2}{*}{$\begin{array}{c}\text { LAW B2 + } \\
15 \% \\
\text { Simulant }\end{array}$} & \multirow{2}{*}{$1150^{\circ} \mathrm{C}$} & Sulfur & 68 & 6.5 & 47 & 122 \\
\hline & & & Iodine & $<1$ & $<0.1$ & 112 & 112 \\
\hline \multirow{2}{*}{$\begin{array}{c}\mathrm{SO}_{3}=0.59 \mathrm{wt} \% \\
{[13]}\end{array}$} & \multirow{2}{*}{$\begin{array}{c}\text { LAW B2 - } \\
15 \% \\
\text { Simulant } \\
\end{array}$} & \multirow[t]{2}{*}{$1150^{\circ} \mathrm{C}$} & Sulfur & 61 & 3.2 & 25 & 89 \\
\hline & & & Iodine & $<1$ & $<0.1$ & 100 & 100 \\
\hline \multirow{2}{*}{$\begin{array}{c}\mathrm{SO}_{3}=0.65 \mathrm{wt} \% \\
{[17]}\end{array}$} & \multirow{2}{*}{ LAW B1 } & \multirow[t]{2}{*}{$1150^{\circ} \mathrm{C}$} & Sulfur & 71 & 8.7 & 32 & 112 \\
\hline & & & Iodine & $<1$ & $<0.1$ & 102 & 102 \\
\hline \multirow{2}{*}{$\begin{array}{c}\mathrm{SO}_{3}=0.72 \mathrm{wt} \% \\
{[12]}\end{array}$} & \multirow{2}{*}{$\begin{array}{c}\text { LAW B1 + } \\
15 \% \\
\text { Simulant } \\
\end{array}$} & \multirow[t]{2}{*}{$1150^{\circ} \mathrm{C}$} & Sulfur & 67 & 7.8 & 27 & 102 \\
\hline & & & Iodine & $<1$ & $<0.1$ & 109 & 109 \\
\hline \multirow{2}{*}{$\begin{array}{c}\mathrm{SO}_{3}=0.65 \mathrm{wt} \% \\
{[12]}\end{array}$} & \multirow{2}{*}{ LAW B1 } & \multirow[t]{2}{*}{$1150^{\circ} \mathrm{C}$} & Sulfur & 69 & 8.0 & 25 & 102 \\
\hline & & & Iodine & $<1$ & $<0.1$ & 88 & 88 \\
\hline \multirow{3}{*}{$\mathrm{SO}_{3}=0.95$ wt $\%$} & \multirow{3}{*}{ LAW A1 } & \multirow{3}{*}{$1150^{\circ} \mathrm{C}$} & Chlorine & 49 & 48 & $<0.1$ & 97 \\
\hline & & & Sulfur & 81 & 7.4 & 0.2 & 88 \\
\hline & & & Iodine & 30 & 4.5 & 83 & 118 \\
\hline \multirow{3}{*}{$\mathrm{SO}_{3}=1.05 \mathrm{wt} \%$} & \multirow{3}{*}{ LAW A1 } & \multirow{3}{*}{$1175^{\circ} \mathrm{C}$} & Chlorine & 49 & 40 & $<0.1$ & 89 \\
\hline & & & Sulfur & 78 & 9.0 & 0.2 & 87 \\
\hline & & & Iodine & 30 & 2.9 & 62 & 95 \\
\hline & & & Chlorine & 66 & 48 & 0.3 & 114 \\
\hline $\mathrm{SO}_{3}=1.1 \mathrm{wt} \%$ & LAW C & $1150^{\circ} \mathrm{C}$ & Sulfur & 95 & 4.0 & 0.2 & 99 \\
\hline & & & Iodine & 10 & 2.9 & 58 & 71 \\
\hline 0.8 carbon ratio* & & & Chlorine & 65 & 50 & 2.4 & 117 \\
\hline$\left(\mathrm{SO}_{3}=1.15 \mathrm{wt} \%\right)$ & LAW C & $1175^{\circ} \mathrm{C}$ & Sulfur & 87 & 6.2 & 5.2 & 98 \\
\hline & & & Iodine & 40 & $<0.1$ & 31 & 71 \\
\hline LAWA161 $\left(\mathrm{SO}_{3}=\right.$ & I AW A & $1150^{\circ} \mathrm{C}$ & Chlorine & 48 & 41 & 0.4 & 89 \\
\hline 1.0 wt\%) [2] & & & Sulfur & 84 & 6.4 & 0.2 & 91 \\
\hline LAWA161 $\left(\mathrm{SO}_{3}=\right.$ & $\mathrm{I} A \mathrm{~W} A$ & $1150^{\circ} \mathrm{C}$ & Chlorine & 52 & 57 & 0.3 & 109 \\
\hline 1.25 wt\%) [2] & & & Sulfur & 90 & 9.6 & 0.2 & 100 \\
\hline Vanadium & $\mathrm{I} \wedge \mathrm{J} J$ & $1150^{\circ} \mathrm{C}$ & Chlorine & 47 & 55 & $<0.1$ & 102 \\
\hline 0.5 wt $\%)$ [4] & LAV $\mathrm{A}$ & & Sulfur & 78 & 14 & 0.4 & 92 \\
\hline$\left(\mathrm{SO}_{3}=0.23 \mathrm{wt} \%\right)$ & IAW A & $1175^{\circ} \mathrm{C}$ & Chlorine & 75 & 42 & $<0.1$ & 117 \\
\hline & & & Sulfur & 91 & 9.2 & 0.4 & 101 \\
\hline$\left(\mathrm{SO}_{3}=0.23 \mathrm{wt} \%\right)$ & $\mathrm{I} A \mathrm{~W} A$ & $1225^{\circ} \mathrm{C}$ & Chlorine & 66 & 61 & $<0.1$ & 127 \\
\hline & LAV $\mathrm{A}$ & 12250 & Sulfur & 81 & 19 & 0.6 & 100 \\
\hline
\end{tabular}

* - stoichiometric carbon ratio of 0.5 used in all tests except where noted. 
Table 7.1. Compositions and Properties of New and Old LAW Envelope A Glasses.

\begin{tabular}{|c|c|c|c|c|}
\hline \multicolumn{2}{|c|}{ Glass Formulation - Sample ID } & LAWA44 (Old) & LAWA126 (Old) & LAWA187 (New) \\
\hline \multicolumn{2}{|c|}{ Waste Composition } & AN-105 & AP-101 & AN-105 \\
\hline \multicolumn{2}{|c|}{ Oxide Loading } & $26.04 \mathrm{wt} \%$ & $24.54 \mathrm{wt} \%$ & $30.46 \mathrm{wt} \%$ \\
\hline \multirow{23}{*}{$\begin{array}{c}\text { Target Glass } \\
\text { Compositions for } \\
\text { Melter Glasses (wt\%) }\end{array}$} & $\mathrm{Al}_{2} \mathrm{O}_{3}$ & 6.10 & 5.61 & 10.62 \\
\hline & $\mathrm{B}_{2} \mathrm{O}_{3}$ & 8.83 & 9.81 & 12.75 \\
\hline & $\mathrm{CaO}$ & 1.96 & 1.99 & 6.47 \\
\hline & $\mathrm{Cr}_{2} \mathrm{O}_{3}$ & 0.02 & 0.02 & 0.52 \\
\hline & $\mathrm{Cs}_{2} \mathrm{O}$ & 0.15 & 0.15 & - \\
\hline & $\mathrm{Fe}_{2} \mathrm{O}_{3}$ & 6.86 & 5.53 & 0.90 \\
\hline & $\mathrm{K}_{2} \mathrm{O}$ & 0.44 & 3.81 & 0.51 \\
\hline & $\mathrm{Li}_{2} \mathrm{O}$ & - & - & - \\
\hline & $\mathrm{MgO}$ & 1.96 & 1.47 & 0.90 \\
\hline & $\mathrm{Na}_{2} \mathrm{O}$ & 20.64 & 18.44 & 22.93 \\
\hline & $\mathrm{NiO}$ & - & - & 0.03 \\
\hline & $\mathrm{SiO}_{2}$ & 43.77 & 43.94 & 34.75 \\
\hline & $\mathrm{SnO}_{2}$ & - & - & 1.00 \\
\hline & $\mathrm{TiO}_{2}$ & 1.96 & 1.98 & - \\
\hline & $\mathrm{V}_{2} \mathrm{O}_{5}$ & - & - & 0.97 \\
\hline & $\mathrm{ZnO}$ & 2.91 & 2.94 & 2.99 \\
\hline & $\mathrm{ZrO}_{2}$ & 2.94 & 2.96 & 2.99 \\
\hline & $\mathrm{Cl}$ & 1.17 & 0.42 & 0.65 \\
\hline & $\mathrm{F}$ & 0.00 & 0.35 & - \\
\hline & $\mathrm{I}$ & 0.10 & 0.10 & 0.10 \\
\hline & $\mathrm{P}_{2} \mathrm{O}_{5}$ & 0.00 & 0.08 & - \\
\hline & $\mathrm{SO}_{3}$ & 0.19 & 0.40 & 0.95 \\
\hline & SUM & 100.0 & 100.0 & 100.0 \\
\hline \multicolumn{2}{|c|}{$\mathrm{SO}_{3}$ Measured in DM100 Melter Glass } & 0.18 & 0.34 & 0.77 \\
\hline \multicolumn{2}{|c|}{$\mathrm{SO}_{3}$ Retention in DM100 Melter Glass } & $95 \%$ & $85 \%$ & $81 \%$ \\
\hline \multirow{3}{*}{ Viscosity $(\mathrm{P})^{*}$} & at $1100^{\circ} \mathrm{C}$ & 114 & 98 & 33 \\
\hline & at $1150^{\circ} \mathrm{C}$ & 69 & 60 & 21 \\
\hline & at $1200^{\circ} \mathrm{C}$ & 44 & 38 & 14 \\
\hline \multirow{3}{*}{$\begin{array}{l}\text { Electrical Conductivity } \\
\qquad(\mathrm{S} / \mathrm{cm})^{*}\end{array}$} & at $1100^{\circ} \mathrm{C}$ & 0.44 & 0.29 & 0.47 \\
\hline & at $1150^{\circ} \mathrm{C}$ & 0.52 & 0.35 & 0.54 \\
\hline & at $1200^{\circ} \mathrm{C}$ & 0.60 & 0.42 & 0.61 \\
\hline \multirow{3}{*}{ PCT $\left(g / m^{2}\right)^{*}$} & $\mathrm{~B}$ & 0.52 & 0.78 & 1.71 \\
\hline & $\mathrm{Na}$ & 0.52 & 0.56 & 1.46 \\
\hline & $\mathrm{Si}$ & 0.20 & 0.20 & 0.25 \\
\hline VHT $\left(\mathrm{g} / \mathrm{m}^{2} / \text { day }\right)^{*}$ & 24 day rate & 1.0 & 0.8 & 25 \\
\hline \multirow{3}{*}{$\begin{array}{c}\text { Glass Production Rate } \\
\left(\mathrm{kg} / \mathrm{m}^{2} / \text { day }\right)\end{array}$} & DM100-1150 ${ }^{\circ} \mathrm{C}$ & $1980[16]$ & 1980[17] & 2140 \\
\hline & $\mathrm{DM} 100-1175^{\circ} \mathrm{C}$ & - & - & 2840 \\
\hline & LAW Pilot $-1150^{\circ} \mathrm{C}$ & $2120[22]$ & 2020 [24] & - \\
\hline Bubbling (lpm) & DM100 & 9.0 & 15.6 & 17.2 \\
\hline
\end{tabular}

* Viscosity, electrical conductivity, PCT and VHT were measured on crucible glasses whose compositions are close to, but very slightly different from, the melter glasses. Crucible glasses do not contain $\mathrm{I}$, and their $\mathrm{SO}_{3}$ contents are different from the melter glasses.

- Empty data field 
Table 7.2. Compositions and Properties of New and Old LAW Envelope B Glasses.

\begin{tabular}{|c|c|c|c|c|}
\hline \multicolumn{2}{|c|}{ Glass Formulation - Sample ID } & LAWB83 (Old) & LAWB96 (Old) & LAWB99 (New) \\
\hline \multicolumn{2}{|c|}{ Waste Composition } & AZ-101 & AZ-102 & AZ-102 \\
\hline \multicolumn{2}{|c|}{ Oxide Loading } & $7.32 \mathrm{wt} \%$ & $3.65 \mathrm{wt} \%$ & $11.93 \mathrm{wt} \%$ \\
\hline \multirow{23}{*}{$\begin{array}{c}\text { Target Glass } \\
\text { Compositions for } \\
\text { Melter Glasses (wt\%) }\end{array}$} & $\mathrm{Al}_{2} \mathrm{O}_{3}$ & 6.16 & 6.16 & 10.06 \\
\hline & $\mathrm{B}_{2} \mathrm{O}_{3}$ & 10.00 & 10.01 & 10.91 \\
\hline & $\mathrm{CaO}$ & 6.75 & 6.76 & 10.11 \\
\hline & $\mathrm{Cr}_{2} \mathrm{O}_{3}$ & 0.03 & 0.03 & 0.11 \\
\hline & $\mathrm{Cs}_{2} \mathrm{O}$ & 0.15 & 0.15 & - \\
\hline & $\mathrm{Fe}_{2} \mathrm{O}_{3}$ & 5.27 & 5.28 & 1.14 \\
\hline & $\mathrm{K}_{2} \mathrm{O}$ & 0.18 & 0.12 & 0.40 \\
\hline & $\mathrm{Li}_{2} \mathrm{O}$ & 4.29 & 4.29 & 3.52 \\
\hline & $\mathrm{MgO}$ & 2.97 & 2.97 & 1.14 \\
\hline & $\mathrm{Na}_{2} \mathrm{O}$ & 5.47 & 5.47 & 9.96 \\
\hline & $\mathrm{NiO}$ & - & 0.01 & - \\
\hline & $\mathrm{PbO}$ & - & - & - \\
\hline & $\mathrm{SiO}_{2}$ & 48.46 & 48.66 & 42.73 \\
\hline & $\mathrm{TiO}_{2}$ & 1.39 & 1.39 & - \\
\hline & $\mathrm{V}_{2} \mathrm{O}_{5}$ & - & - & 1.23 \\
\hline & $\mathrm{ZnO}$ & 4.83 & 4.85 & 3.51 \\
\hline & $\mathrm{ZrO}_{2}$ & 3.16 & 3.17 & 3.51 \\
\hline & $\mathrm{Cl}$ & 0.02 & 0.01 & 0.01 \\
\hline & $\mathrm{F}$ & 0.08 & 0.02 & 0.07 \\
\hline & $\mathrm{I}$ & 0.10 & - & 0.10 \\
\hline & $\mathrm{P}_{2} \mathrm{O}_{5}$ & 0.04 & 0.01 & 0.03 \\
\hline & $\mathrm{SO}_{3}$ & 0.65 & 0.65 & 1.50 \\
\hline & SUM & 100.0 & 100.0 & 100.0 \\
\hline \multicolumn{2}{|c|}{$\mathrm{SO}_{3}$ Measured in DM100 Melter Glass } & 0.46 & - & 1.14 \\
\hline \multicolumn{2}{|c|}{$\mathrm{SO}_{3}$ Retention in DM100 Melter Glass } & $71 \%$ & - & $76 \%$ \\
\hline \multirow{3}{*}{ Viscosity $(\mathrm{P})^{*}$} & at $1100^{\circ} \mathrm{C}$ & 88 & 74 & 56 \\
\hline & at $1150^{\circ} \mathrm{C}$ & 53 & 45 & 35 \\
\hline & at $1200^{\circ} \mathrm{C}$ & 33 & 29 & 23 \\
\hline \multirow{3}{*}{$\begin{array}{l}\text { Electrical Conductivity } \\
\qquad(\mathrm{S} / \mathrm{cm})^{*}\end{array}$} & at $1100^{\circ} \mathrm{C}$ & 0.16 & 0.15 & 0.25 \\
\hline & at $1150^{\circ} \mathrm{C}$ & 0.20 & 0.19 & 0.32 \\
\hline & at $1200^{\circ} \mathrm{C}$ & 0.24 & 0.24 & 0.41 \\
\hline \multirow{3}{*}{ PCT $\left(g / m^{2}\right)^{*}$} & $\mathrm{~B}$ & 0.39 & 0.28 & 0.12 \\
\hline & $\mathrm{Na}$ & 0.27 & 0.28 & 0.21 \\
\hline & $\mathrm{Si}$ & 0.13 & 0.12 & 0.07 \\
\hline VHT $\left(\mathrm{g} / \mathrm{m}^{2} / \text { day }\right)^{*}$ & 24 day rate & 1.5 & 4.5 & 15 \\
\hline \multirow{3}{*}{$\begin{array}{c}\text { Glass Production Rate } \\
\left(\mathrm{kg} / \mathrm{m}^{2} / \text { day }\right)\end{array}$} & DM100- $1150^{\circ} \mathrm{C}$ & $2000[16]$ & - & 2200 \\
\hline & $\mathrm{DM} 100-1175^{\circ} \mathrm{C}$ & - & - & 2700 \\
\hline & LAW Pilot $-1150^{\circ} \mathrm{C}$ & $2200[22]$ & $1880[30]$ & - \\
\hline Bubbling (lpm) & DM100 & 14.3 & - & 8.9 \\
\hline
\end{tabular}

* Viscosity, electrical conductivity, PCT and VHT were measured on crucible glasses whose compositions are close to, but very slightly different from, the melter glasses. Crucible glasses do not contain $\mathrm{I}$, and their $\mathrm{SO}_{3}$ contents are different from the melter glasses.

- Empty data field 
Table 8.1. Tank-by-Tank $\mathrm{Na}_{2} \mathrm{O}$ and $\mathrm{SO}_{3}$ Loadings in Glass and Mass of Glass Product Based on (i) The Current WTP Baseline LAW Glass Composition Correlation [57] and (ii) The Enhanced Formulations Developed in the Present Work.

\begin{tabular}{|c|c|c|c|c|c|c|}
\hline \multirow[b]{2}{*}{ Tank } & $\mathrm{Na}_{2} \mathrm{O}$ wt $\%$ & $\mathrm{SO}_{3} \mathrm{wt} \%$ & kg Glass & kg Glass & $\mathrm{Na}_{2} \mathrm{O}$ wt $\%$ & $\mathrm{SO}_{3} \mathrm{wt} \%$ \\
\hline & \multicolumn{3}{|c|}{ Per LAW Correlation [57] } & \multicolumn{3}{|c|}{$\begin{array}{c}\text { Per Enhanced Formulations from the } \\
\text { Present Work }\end{array}$} \\
\hline A-101 & 11.68 & 0.57 & $8.91 \mathrm{E}+06$ & $4.83 \mathrm{E}+06$ & 21.57 & 1.05 \\
\hline A-102 & 7.96 & 0.66 & $6.18 \mathrm{E}+05$ & $3.25 \mathrm{E}+05$ & 15.15 & 1.25 \\
\hline A-103 & 12.51 & 0.55 & $4.76 \mathrm{E}+06$ & $2.56 \mathrm{E}+06$ & 23.32 & 1.02 \\
\hline A-104 & 15.03 & 0.49 & $1.49 \mathrm{E}+05$ & $9.60 \mathrm{E}+04$ & 23.31 & 0.76 \\
\hline A-105 & 8.95 & 0.63 & $9.69 \mathrm{E}+05$ & $4.91 \mathrm{E}+05$ & 17.68 & 1.25 \\
\hline A-106 & 21.00 & 0.32 & $5.89 \mathrm{E}+05$ & $5.35 E+05$ & 23.12 & 0.35 \\
\hline AN-101 & 21.00 & 0.15 & $6.62 \mathrm{E}+05$ & $6.03 \mathrm{E}+05$ & 23.06 & 0.17 \\
\hline AN-102 & 12.84 & 0.54 & $1.13 \mathrm{E}+07$ & $6.25 \mathrm{E}+06$ & 23.20 & 0.98 \\
\hline AN-103 & 21.00 & 0.12 & $7.96 \mathrm{E}+06$ & $7.27 \mathrm{E}+06$ & 22.99 & 0.13 \\
\hline AN-104 & 19.85 & 0.38 & $8.50 \mathrm{E}+06$ & $7.28 \mathrm{E}+06$ & 23.17 & 0.44 \\
\hline AN-105 & 21.00 & 0.29 & $8.26 \mathrm{E}+06$ & $7.49 \mathrm{E}+06$ & 23.17 & 0.32 \\
\hline AN-106 & 14.82 & 0.49 & $3.27 \mathrm{E}+05$ & $2.12 \mathrm{E}+05$ & 22.89 & 0.76 \\
\hline AN-107 & 18.58 & 0.41 & $8.57 \mathrm{E}+06$ & $6.84 \mathrm{E}+06$ & 23.27 & 0.51 \\
\hline AP-101 & 19.17 & 0.32 & $4.48 \mathrm{E}+06$ & $4.13 \mathrm{E}+06$ & 20.81 & 0.34 \\
\hline AP-102 & 21.00 & 0.10 & $1.43 \mathrm{E}+06$ & $1.31 \mathrm{E}+06$ & 23.01 & 0.11 \\
\hline AP-103 & 20.75 & 0.27 & $1.49 \mathrm{E}+06$ & $1.37 \mathrm{E}+06$ & 22.52 & 0.30 \\
\hline AP-104 & 21.00 & 0.28 & $4.15 E+06$ & $3.76 \mathrm{E}+06$ & 23.17 & 0.31 \\
\hline AP-105 & 20.83 & 0.35 & $5.89 \mathrm{E}+06$ & $5.42 \mathrm{E}+06$ & 22.62 & 0.38 \\
\hline AP-106 & 20.14 & 0.37 & $3.52 \mathrm{E}+06$ & $3.06 \mathrm{E}+06$ & 23.15 & 0.42 \\
\hline AP-107 & 21.00 & 0.11 & $5.34 \mathrm{E}+06$ & $4.81 \mathrm{E}+06$ & 23.33 & 0.12 \\
\hline AP-108 & 21.00 & 0.22 & $3.58 \mathrm{E}+06$ & $3.22 \mathrm{E}+06$ & 23.33 & 0.25 \\
\hline AW-101 & 20.40 & 0.13 & $8.43 E+06$ & $7.76 \mathrm{E}+06$ & 22.14 & 0.14 \\
\hline AW-102 & 21.00 & 0.28 & $3.51 \mathrm{E}+06$ & $3.16 \mathrm{E}+06$ & 23.33 & 0.31 \\
\hline AW-103 & 21.00 & 0.22 & $4.24 \mathrm{E}+06$ & $3.85 \mathrm{E}+06$ & 23.17 & 0.24 \\
\hline AW-104 & 12.85 & 0.54 & $3.02 E+06$ & $1.68 \mathrm{E}+06$ & 23.07 & 0.97 \\
\hline AW-105 & 21.00 & 0.17 & $1.09 \mathrm{E}+06$ & $9.84 \mathrm{E}+05$ & 23.23 & 0.19 \\
\hline AW-106 & 13.27 & 0.53 & $3.53 \mathrm{E}+06$ & $2.04 \mathrm{E}+06$ & 22.92 & 0.92 \\
\hline AX-101 & 10.39 & 0.60 & $7.33 \mathrm{E}+06$ & $3.80 \mathrm{E}+06$ & 20.02 & 1.15 \\
\hline AX-102 & 21.00 & 0.27 & $1.94 \mathrm{E}+05$ & $1.75 \mathrm{E}+05$ & 23.30 & 0.30 \\
\hline AX-103 & 11.11 & 0.58 & $1.56 \mathrm{E}+06$ & $8.62 \mathrm{E}+05$ & 20.11 & 1.05 \\
\hline AX-104 & 10.32 & 0.60 & $3.32 \mathrm{E}+04$ & $1.69 \mathrm{E}+04$ & 20.22 & 1.18 \\
\hline AY-101 & 14.85 & 0.49 & $9.81 \mathrm{E}+05$ & $6.25 E+05$ & 23.33 & 0.78 \\
\hline AY-102 & 21.00 & 0.27 & $1.80 \mathrm{E}+06$ & $1.62 \mathrm{E}+06$ & 23.31 & 0.30 \\
\hline AZ-101 & 8.36 & 0.65 & $6.87 \mathrm{E}+06$ & $3.55 \mathrm{E}+06$ & 16.15 & 1.25 \\
\hline AZ-102 & 5.07 & 0.72 & $7.12 \mathrm{E}+06$ & $3.59 \mathrm{E}+06$ & 10.05 & 1.44 \\
\hline B-101 & 4.37 & 0.74 & $4.01 \mathrm{E}+06$ & $1.85 \mathrm{E}+06$ & 9.44 & 1.60 \\
\hline B-102 & 3.78 & 0.75 & $1.30 \mathrm{E}+06$ & $6.15 \mathrm{E}+05$ & 8.01 & 1.60 \\
\hline B-103 & 3.73 & 0.76 & $2.45 E+06$ & $1.16 \mathrm{E}+06$ & 7.90 & 1.60 \\
\hline B-104 & 7.00 & 0.68 & $5.05 E+06$ & $2.74 \mathrm{E}+06$ & 12.89 & 1.25 \\
\hline
\end{tabular}


Table 8.1. Tank-by-Tank $\mathrm{Na}_{2} \mathrm{O}$ and $\mathrm{SO}_{3}$ Loadings in Glass and Mass of Glass Product Based on (i) The Current WTP Baseline LAW Glass Composition Correlation [57] and (ii) The Enhanced Formulations Developed in the Present Work (continued).

\begin{tabular}{|c|c|c|c|c|c|c|}
\hline \multirow[b]{2}{*}{ Tank } & $\mathrm{Na}_{2} \mathrm{O}$ wt $\%$ & $\mathrm{SO}_{3} \mathrm{wt} \%$ & kg Glass & kg Glass & $\mathrm{Na}_{2} \mathrm{O} w t \%$ & $\mathrm{SO}_{3} \mathrm{wt} \%$ \\
\hline & \multicolumn{3}{|c|}{ Per LAW Correlation [57] } & \multicolumn{3}{|c|}{$\begin{array}{c}\text { Per Enhanced Formulations from the } \\
\text { Present Work }\end{array}$} \\
\hline B-105 & 3.65 & 0.76 & $1.41 \mathrm{E}+07$ & $6.67 \mathrm{E}+06$ & 7.71 & 1.60 \\
\hline B-106 & 8.21 & 0.65 & $1.36 \mathrm{E}+06$ & $7.07 \mathrm{E}+05$ & 15.78 & 1.25 \\
\hline B-107 & 2.84 & 0.78 & $8.26 \mathrm{E}+06$ & $4.01 \mathrm{E}+06$ & 5.86 & 1.60 \\
\hline B-108 & 3.35 & 0.76 & $5.23 E+06$ & $2.50 \mathrm{E}+06$ & 7.00 & 1.60 \\
\hline B-109 & 4.41 & 0.74 & $5.61 \mathrm{E}+06$ & $2.59 \mathrm{E}+06$ & 9.55 & 1.60 \\
\hline B-110 & 9.83 & 0.61 & $1.97 \mathrm{E}+06$ & $9.67 \mathrm{E}+05$ & 20.07 & 1.25 \\
\hline B-111 & 9.08 & 0.63 & $1.65 \mathrm{E}+06$ & $8.33 \mathrm{E}+05$ & 18.02 & 1.25 \\
\hline B-112 & 9.50 & 0.62 & $4.65 \mathrm{E}+05$ & $2.31 \mathrm{E}+05$ & 19.14 & 1.25 \\
\hline B-201 & 20.58 & 0.11 & $3.80 \mathrm{E}+04$ & $3.50 \mathrm{E}+04$ & 22.34 & 0.12 \\
\hline B-202 & 18.75 & 0.40 & $4.47 \mathrm{E}+04$ & $3.94 \mathrm{E}+04$ & 21.31 & 0.46 \\
\hline B-203 & 19.75 & 0.10 & $5.35 E+04$ & $4.93 E+04$ & 21.44 & 0.10 \\
\hline B-204 & 21.00 & 0.12 & $4.50 \mathrm{E}+04$ & $4.06 \mathrm{E}+04$ & 23.29 & 0.13 \\
\hline BX-101 & 10.06 & 0.61 & $2.55 \mathrm{E}+05$ & $1.27 \mathrm{E}+05$ & 20.29 & 1.22 \\
\hline BX-102 & 13.79 & 0.52 & $1.22 \mathrm{E}+05$ & $7.28 \mathrm{E}+04$ & 23.18 & 0.87 \\
\hline BX-103 & 9.69 & 0.62 & $3.55 \mathrm{E}+05$ & $1.75 \mathrm{E}+05$ & 19.68 & 1.25 \\
\hline BX-104 & 21.00 & 0.28 & $3.20 \mathrm{E}+05$ & $2.88 \mathrm{E}+05$ & 23.32 & 0.31 \\
\hline BX-105 & 12.78 & 0.54 & $6.55 \mathrm{E}+05$ & $3.59 \mathrm{E}+05$ & 23.33 & 0.99 \\
\hline BX-106 & 21.00 & 0.10 & $2.73 \mathrm{E}+05$ & $2.48 \mathrm{E}+05$ & 23.18 & 0.11 \\
\hline BX-107 & 8.90 & 0.63 & $3.40 \mathrm{E}+06$ & $1.73 \mathrm{E}+06$ & 17.54 & 1.25 \\
\hline BX-108 & 8.11 & 0.65 & $5.85 \mathrm{E}+05$ & $3.05 E+05$ & 15.55 & 1.25 \\
\hline BX-109 & 7.12 & 0.68 & $2.59 \mathrm{E}+06$ & $1.40 \mathrm{E}+06$ & 13.18 & 1.25 \\
\hline BX-110 & 16.20 & 0.46 & $2.67 \mathrm{E}+06$ & $1.85 \mathrm{E}+06$ & 23.34 & 0.67 \\
\hline BX-111 & 21.00 & 0.22 & $1.85 \mathrm{E}+06$ & $1.67 \mathrm{E}+06$ & 23.26 & 0.24 \\
\hline BX-112 & 12.42 & 0.55 & $8.60 \mathrm{E}+05$ & $4.57 \mathrm{E}+05$ & 23.34 & 1.04 \\
\hline BY-101 & 21.00 & 0.13 & $4.53 \mathrm{E}+06$ & $4.09 \mathrm{E}+06$ & 23.23 & 0.14 \\
\hline BY-102 & 7.67 & 0.66 & $8.82 \mathrm{E}+06$ & $4.68 \mathrm{E}+06$ & 14.46 & 1.25 \\
\hline BY-103 & 13.55 & 0.52 & $6.61 \mathrm{E}+06$ & $3.86 \mathrm{E}+06$ & 23.22 & 0.90 \\
\hline BY-104 & 11.66 & 0.57 & $6.34 \mathrm{E}+06$ & $3.44 \mathrm{E}+06$ & 21.52 & 1.05 \\
\hline BY-105 & 20.94 & 0.35 & $5.20 \mathrm{E}+06$ & $4.67 \mathrm{E}+06$ & 23.31 & 0.39 \\
\hline BY-106 & 16.89 & 0.45 & $5.73 E+06$ & $4.18 \mathrm{E}+06$ & 23.19 & 0.61 \\
\hline BY-107 & 15.06 & 0.49 & $4.43 \mathrm{E}+06$ & $2.88 \mathrm{E}+06$ & 23.13 & 0.75 \\
\hline BY-108 & 10.17 & 0.60 & $3.61 \mathrm{E}+06$ & $1.82 \mathrm{E}+06$ & 20.22 & 1.20 \\
\hline BY-109 & 4.42 & 0.74 & $1.16 \mathrm{E}+07$ & $5.36 \mathrm{E}+06$ & 9.55 & 1.60 \\
\hline BY-110 & 11.38 & 0.58 & $6.47 \mathrm{E}+06$ & $3.55 \mathrm{E}+06$ & 20.76 & 1.05 \\
\hline BY-111 & 8.35 & 0.65 & $8.64 \mathrm{E}+06$ & $4.47 \mathrm{E}+06$ & 16.15 & 1.25 \\
\hline BY-112 & 12.08 & 0.56 & $7.69 \mathrm{E}+06$ & $4.10 \mathrm{E}+06$ & 22.68 & 1.05 \\
\hline C-101 & 10.20 & 0.60 & $8.81 \mathrm{E}+05$ & $4.45 \mathrm{E}+05$ & 20.20 & 1.19 \\
\hline C-102 & 16.16 & 0.46 & $1.03 \mathrm{E}+06$ & $7.21 \mathrm{E}+05$ & 23.18 & 0.66 \\
\hline C-103 & 11.39 & 0.58 & $4.08 \mathrm{E}+05$ & $2.24 \mathrm{E}+05$ & 20.79 & 1.05 \\
\hline C-104 & 21.00 & 0.21 & $1.34 \mathrm{E}+06$ & $1.21 \mathrm{E}+06$ & 23.25 & 0.24 \\
\hline
\end{tabular}


Table 8.1. Tank-by-Tank $\mathrm{Na}_{2} \mathrm{O}$ and $\mathrm{SO}_{3}$ Loadings in Glass and Mass of Glass Product Based on (i) The Current WTP Baseline LAW Glass Composition Correlation [57] and (ii) The Enhanced Formulations Developed in the Present Work (continued).

\begin{tabular}{|c|c|c|c|c|c|c|}
\hline \multirow[b]{2}{*}{ Tank } & $\mathrm{Na}_{2} \mathrm{O}$ wt $\%$ & $\mathrm{SO}_{3} \mathrm{wt} \%$ & kg Glass & kg Glass & $\mathrm{Na}_{2} \mathrm{O}$ wt $\%$ & $\mathrm{SO}_{3} \mathrm{wt} \%$ \\
\hline & \multicolumn{3}{|c|}{ Per LAW Correlation [57] } & \multicolumn{3}{|c|}{$\begin{array}{l}\text { Per Enhanced Formulations from the } \\
\text { Present Work }\end{array}$} \\
\hline C-105 & 10.49 & 0.60 & $4.94 \mathrm{E}+05$ & $2.56 \mathrm{E}+05$ & 20.26 & 1.15 \\
\hline C-106 & 18.85 & 0.40 & $1.00 \mathrm{E}+05$ & $8.13 \mathrm{E}+04$ & 23.27 & 0.49 \\
\hline C-107 & 11.99 & 0.56 & $1.25 \mathrm{E}+06$ & $6.69 \mathrm{E}+05$ & 22.44 & 1.05 \\
\hline C-108 & 13.79 & 0.52 & $3.90 \mathrm{E}+05$ & $2.31 \mathrm{E}+05$ & 23.29 & 0.88 \\
\hline C-109 & 12.37 & 0.55 & $4.44 \mathrm{E}+05$ & $2.36 \mathrm{E}+05$ & 23.28 & 1.04 \\
\hline C-110 & 8.32 & 0.65 & $1.43 \mathrm{E}+06$ & $7.40 \mathrm{E}+05$ & 16.05 & 1.25 \\
\hline $\mathrm{C}-111$ & 9.86 & 0.61 & $2.03 E+05$ & $9.98 \mathrm{E}+04$ & 20.07 & 1.24 \\
\hline C-112 & 8.65 & 0.64 & $9.13 \mathrm{E}+05$ & $4.67 \mathrm{E}+05$ & 16.91 & 1.25 \\
\hline C-201 & 21.00 & 0.27 & $3.47 \mathrm{E}+03$ & $3.14 \mathrm{E}+03$ & 23.22 & 0.30 \\
\hline C-202 & 14.89 & 0.49 & $5.10 \mathrm{E}+03$ & $3.27 \mathrm{E}+03$ & 23.28 & 0.77 \\
\hline C-203 & 18.11 & 0.42 & $8.02 E+03$ & $6.29 E+03$ & 23.08 & 0.53 \\
\hline C-204 & 18.13 & 0.42 & $5.18 \mathrm{E}+03$ & $4.08 \mathrm{E}+03$ & 22.98 & 0.53 \\
\hline S-101 & 18.85 & 0.40 & $3.27 \mathrm{E}+06$ & $2.64 \mathrm{E}+06$ & 23.32 & 0.49 \\
\hline S-102 & 21.00 & 0.27 & $2.73 E+06$ & $2.46 \mathrm{E}+06$ & 23.31 & 0.30 \\
\hline S-103 & 16.18 & 0.46 & $2.57 \mathrm{E}+06$ & $1.79 E+06$ & 23.31 & 0.67 \\
\hline S-104 & 21.00 & 0.10 & $1.68 \mathrm{E}+06$ & $1.52 \mathrm{E}+06$ & 23.30 & 0.11 \\
\hline S-105 & 20.82 & 0.35 & $4.73 E+06$ & $4.23 \mathrm{E}+06$ & 23.31 & 0.40 \\
\hline S-106 & 20.13 & 0.37 & $4.71 E+06$ & $4.06 \mathrm{E}+06$ & 23.33 & 0.43 \\
\hline S-107 & 21.00 & 0.16 & $1.73 E+06$ & $1.56 \mathrm{E}+06$ & 23.30 & 0.18 \\
\hline S-108 & 14.30 & 0.51 & $7.69 \mathrm{E}+06$ & $4.72 \mathrm{E}+06$ & 23.28 & 0.83 \\
\hline S-109 & 20.75 & 0.36 & $5.86 \mathrm{E}+06$ & $5.21 \mathrm{E}+06$ & 23.32 & 0.40 \\
\hline S-110 & 17.23 & 0.44 & $4.41 \mathrm{E}+06$ & $3.26 \mathrm{E}+06$ & 23.33 & 0.59 \\
\hline S-111 & 13.47 & 0.53 & $4.91 \mathrm{E}+06$ & $2.83 \mathrm{E}+06$ & 23.31 & 0.91 \\
\hline S-112 & 8.88 & 0.63 & $1.75 \mathrm{E}+07$ & $8.87 \mathrm{E}+06$ & 17.48 & 1.25 \\
\hline SX-101 & 21.00 & 0.11 & $3.81 E+06$ & $3.44 \mathrm{E}+06$ & 23.30 & 0.12 \\
\hline SX-102 & 16.59 & 0.45 & $5.50 \mathrm{E}+06$ & $3.91 \mathrm{E}+06$ & 23.30 & 0.64 \\
\hline SX-103 & 14.58 & 0.50 & $6.94 \mathrm{E}+06$ & $4.35 \mathrm{E}+06$ & 23.26 & 0.80 \\
\hline SX-104 & 16.95 & 0.44 & $4.46 \mathrm{E}+06$ & $3.24 \mathrm{E}+06$ & 23.32 & 0.61 \\
\hline SX-105 & 16.94 & 0.45 & $3.54 \mathrm{E}+06$ & $2.58 \mathrm{E}+06$ & 23.22 & 0.61 \\
\hline SX-106 & 21.00 & 0.27 & $3.33 \mathrm{E}+06$ & $3.00 \mathrm{E}+06$ & 23.32 & 0.30 \\
\hline SX-107 & 21.00 & 0.20 & $5.45 \mathrm{E}+05$ & $4.92 \mathrm{E}+05$ & 23.26 & 0.22 \\
\hline SX-108 & 21.00 & 0.12 & $6.69 \mathrm{E}+05$ & $6.03 E+05$ & 23.30 & 0.13 \\
\hline SX-109 & 21.00 & 0.10 & $1.94 \mathrm{E}+06$ & $1.75 E+06$ & 23.28 & 0.11 \\
\hline SX-110 & 21.00 & 0.14 & $3.94 \mathrm{E}+05$ & $3.56 \mathrm{E}+05$ & 23.28 & 0.15 \\
\hline SX-111 & 21.00 & 0.18 & $7.27 \mathrm{E}+05$ & $6.56 \mathrm{E}+05$ & 23.27 & 0.19 \\
\hline SX-112 & 21.00 & 0.19 & $4.52 \mathrm{E}+05$ & $4.08 \mathrm{E}+05$ & 23.27 & 0.21 \\
\hline SX-113 & 20.22 & 0.19 & $5.91 \mathrm{E}+03$ & $5.45 \mathrm{E}+03$ & 21.94 & 0.20 \\
\hline SX-114 & 21.00 & 0.13 & $1.18 \mathrm{E}+06$ & $1.06 \mathrm{E}+06$ & 23.28 & 0.15 \\
\hline
\end{tabular}


Table 8.1. Tank-by-Tank $\mathrm{Na}_{2} \mathrm{O}$ and $\mathrm{SO}_{3}$ Loadings in Glass and Mass of Glass Product Based on (i) The Current WTP Baseline LAW Glass Composition Correlation [57] and (ii) The Enhanced Formulations Developed in the Present Work (continued).

\begin{tabular}{|c|c|c|c|c|c|c|}
\hline \multirow[b]{2}{*}{ Tank } & $\mathrm{Na}_{2} \mathrm{O}$ wt $\%$ & $\mathrm{SO}_{3} \mathrm{wt} \%$ & kg Glass & kg Glass & $\mathrm{Na}_{2} \mathrm{O}$ wt $\%$ & $\mathrm{SO}_{3} \mathrm{wt} \%$ \\
\hline & \multicolumn{3}{|c|}{ Per LAW Correlation [57] } & \multicolumn{3}{|c|}{$\begin{array}{l}\text { Per Enhanced Formulations from the } \\
\text { Present Work }\end{array}$} \\
\hline SX-115 & 10.85 & 0.59 & $8.98 \mathrm{E}+03$ & $4.88 \mathrm{E}+03$ & 19.95 & 1.08 \\
\hline SY-101 & 21.00 & 0.27 & $4.84 \mathrm{E}+06$ & $4.39 \mathrm{E}+06$ & 23.18 & 0.29 \\
\hline SY-102 & 21.00 & 0.22 & $3.00 \mathrm{E}+06$ & $2.71 \mathrm{E}+06$ & 23.21 & 0.24 \\
\hline SY-103 & 21.00 & 0.30 & $5.33 \mathrm{E}+06$ & $4.82 \mathrm{E}+06$ & 23.25 & 0.33 \\
\hline $\mathrm{T}-101$ & 10.45 & 0.60 & $1.29 \mathrm{E}+06$ & $6.69 \mathrm{E}+05$ & 20.23 & 1.16 \\
\hline $\mathrm{T}-102$ & 15.59 & 0.48 & $7.76 \mathrm{E}+04$ & $5.21 \mathrm{E}+04$ & 23.21 & 0.71 \\
\hline $\mathrm{T}-103$ & 14.79 & 0.50 & $8.05 E+04$ & $5.11 \mathrm{E}+04$ & 23.32 & 0.78 \\
\hline $\mathrm{T}-104$ & 15.37 & 0.48 & $1.02 \mathrm{E}+06$ & $6.74 \mathrm{E}+05$ & 23.34 & 0.73 \\
\hline $\mathrm{T}-105$ & 9.66 & 0.62 & $6.45 \mathrm{E}+05$ & $3.18 \mathrm{E}+05$ & 19.59 & 1.25 \\
\hline $\mathrm{T}-106$ & 10.60 & 0.59 & $1.98 \mathrm{E}+05$ & $1.04 \mathrm{E}+05$ & 20.24 & 1.13 \\
\hline T-107 & 9.25 & 0.63 & $1.61 \mathrm{E}+06$ & $8.07 \mathrm{E}+05$ & 18.47 & 1.25 \\
\hline $\mathrm{T}-108$ & 18.19 & 0.42 & $1.23 \mathrm{E}+05$ & $9.61 \mathrm{E}+04$ & 23.31 & 0.53 \\
\hline T-109 & 21.00 & 0.25 & $4.31 \mathrm{E}+05$ & $3.88 \mathrm{E}+05$ & 23.32 & 0.28 \\
\hline $\mathrm{T}-110$ & 8.85 & 0.64 & $1.57 \mathrm{E}+06$ & $8.00 \mathrm{E}+05$ & 17.41 & 1.25 \\
\hline $\mathrm{T}-111$ & 10.93 & 0.59 & $9.75 \mathrm{E}+05$ & $5.33 E+05$ & 20.00 & 1.07 \\
\hline T-112 & 8.82 & 0.64 & $3.74 \mathrm{E}+05$ & $1.90 \mathrm{E}+05$ & 17.35 & 1.25 \\
\hline T-201 & 20.03 & 0.20 & $3.30 \mathrm{E}+04$ & $3.04 \mathrm{E}+04$ & 21.74 & 0.22 \\
\hline $\mathrm{T}-202$ & 18.62 & 0.41 & $2.79 E+04$ & $2.45 E+04$ & 21.23 & 0.46 \\
\hline T-203 & 19.53 & 0.14 & $4.75 E+04$ & $4.38 \mathrm{E}+04$ & 21.20 & 0.15 \\
\hline T-204 & 19.57 & 0.12 & $4.34 \mathrm{E}+04$ & $4.00 \mathrm{E}+04$ & 21.24 & 0.13 \\
\hline TX-101 & 17.02 & 0.44 & $6.62 \mathrm{E}+05$ & $4.84 \mathrm{E}+05$ & 23.26 & 0.61 \\
\hline TX-102 & 9.71 & 0.62 & $4.40 \mathrm{E}+06$ & $2.17 \mathrm{E}+06$ & 19.72 & 1.25 \\
\hline TX-103 & 9.72 & 0.61 & $2.97 \mathrm{E}+06$ & $1.46 \mathrm{E}+06$ & 19.77 & 1.25 \\
\hline TX-104 & 21.00 & 0.15 & $3.92 \mathrm{E}+05$ & $3.54 \mathrm{E}+05$ & 23.29 & 0.17 \\
\hline TX-105 & 9.70 & 0.62 & $1.20 \mathrm{E}+07$ & $5.92 \mathrm{E}+06$ & 19.71 & 1.25 \\
\hline TX-106 & 9.73 & 0.61 & $7.12 \mathrm{E}+06$ & $3.50 \mathrm{E}+06$ & 19.78 & 1.25 \\
\hline TX-107 & 11.40 & 0.58 & $5.59 \mathrm{E}+05$ & $3.06 \mathrm{E}+05$ & 20.80 & 1.05 \\
\hline TX-108 & 9.64 & 0.62 & $2.65 \mathrm{E}+06$ & $1.31 \mathrm{E}+06$ & 19.55 & 1.25 \\
\hline TX-109 & 8.81 & 0.64 & $3.28 \mathrm{E}+06$ & $1.67 \mathrm{E}+06$ & 17.31 & 1.25 \\
\hline TX-110 & 9.63 & 0.62 & $9.50 \mathrm{E}+06$ & $4.69 \mathrm{E}+06$ & 19.52 & 1.25 \\
\hline TX-111 & 9.61 & 0.62 & $7.29 \mathrm{E}+06$ & $3.60 \mathrm{E}+06$ & 19.45 & 1.25 \\
\hline TX-112 & 9.76 & 0.61 & $1.32 \mathrm{E}+07$ & $6.50 \mathrm{E}+06$ & 19.87 & 1.25 \\
\hline TX-113 & 5.55 & 0.71 & $2.61 \mathrm{E}+07$ & $1.41 \mathrm{E}+07$ & 10.27 & 1.32 \\
\hline TX-114 & 9.92 & 0.61 & $1.08 \mathrm{E}+07$ & $5.30 \mathrm{E}+06$ & 20.25 & 1.25 \\
\hline TX-115 & 9.66 & 0.62 & $1.16 \mathrm{E}+07$ & $5.73 \mathrm{E}+06$ & 19.58 & 1.25 \\
\hline TX-116 & 9.42 & 0.62 & $1.19 \mathrm{E}+07$ & $5.90 \mathrm{E}+06$ & 18.92 & 1.25 \\
\hline TX-117 & 10.99 & 0.58 & $8.32 \mathrm{E}+06$ & $4.51 \mathrm{E}+06$ & 20.26 & 1.08 \\
\hline TX-118 & 19.53 & 0.38 & $2.43 E+06$ & $2.04 \mathrm{E}+06$ & 23.30 & 0.46 \\
\hline
\end{tabular}


Table 8.1. Tank-by-Tank $\mathrm{Na}_{2} \mathrm{O}$ and $\mathrm{SO}_{3}$ Loadings in Glass and Mass of Glass Product Based on (i) The Current WTP Baseline LAW Glass Composition Correlation [57] and (ii) The Enhanced Formulations Developed in the Present Work (continued).

\begin{tabular}{|c|c|c|c|c|c|c|}
\hline \multirow[b]{2}{*}{ Tank } & $\mathrm{Na}_{2} \mathrm{O}$ wt $\%$ & $\mathrm{SO}_{3} \mathrm{wt} \%$ & kg Glass & kg Glass & $\mathrm{Na}_{2} \mathrm{O}$ wt $\%$ & $\mathrm{SO}_{3} \mathrm{wt} \%$ \\
\hline & \multicolumn{3}{|c|}{ Per LAW Correlation [57] } & \multicolumn{3}{|c|}{$\begin{array}{l}\text { Per Enhanced Formulations from the } \\
\text { Present Work }\end{array}$} \\
\hline TY-101 & 17.70 & 0.43 & $7.90 \mathrm{E}+05$ & $6.00 \mathrm{E}+05$ & 23.32 & 0.56 \\
\hline TY-102 & 11.69 & 0.57 & $1.18 \mathrm{E}+06$ & $6.38 \mathrm{E}+05$ & 21.60 & 1.05 \\
\hline TY-103 & 12.20 & 0.56 & $1.51 \mathrm{E}+06$ & $8.02 E+05$ & 23.02 & 1.05 \\
\hline TY-104 & 17.57 & 0.43 & $2.83 \mathrm{E}+05$ & $2.13 \mathrm{E}+05$ & 23.32 & 0.57 \\
\hline TY-105 & 7.48 & 0.67 & $3.25 E+06$ & $1.73 \mathrm{E}+06$ & 14.01 & 1.25 \\
\hline TY-106 & 7.67 & 0.66 & $1.83 \mathrm{E}+05$ & $9.73 \mathrm{E}+04$ & 14.45 & 1.25 \\
\hline $\mathrm{U}-101$ & 21.00 & 0.23 & $1.16 \mathrm{E}+05$ & $1.04 \mathrm{E}+05$ & 23.26 & 0.25 \\
\hline U-102 & 14.34 & 0.51 & $3.51 \mathrm{E}+06$ & $2.16 \mathrm{E}+06$ & 23.31 & 0.82 \\
\hline U-103 & 14.80 & 0.50 & $5.03 \mathrm{E}+06$ & $3.20 \mathrm{E}+06$ & 23.27 & 0.78 \\
\hline U-104 & 21.00 & 0.19 & $4.33 \mathrm{E}+05$ & $3.91 \mathrm{E}+05$ & 23.26 & 0.21 \\
\hline U-105 & 11.95 & 0.56 & $5.44 \mathrm{E}+06$ & $2.91 \mathrm{E}+06$ & 22.31 & 1.05 \\
\hline U-106 & 16.80 & 0.45 & $1.66 \mathrm{E}+06$ & $1.20 \mathrm{E}+06$ & 23.26 & 0.62 \\
\hline U-107 & 21.00 & 0.15 & $3.44 \mathrm{E}+06$ & $3.10 \mathrm{E}+06$ & 23.28 & 0.17 \\
\hline U-108 & 15.94 & 0.47 & $5.98 \mathrm{E}+06$ & $4.09 \mathrm{E}+06$ & 23.26 & 0.68 \\
\hline U-109 & 14.45 & 0.50 & $3.72 \mathrm{E}+06$ & $2.31 \mathrm{E}+06$ & 23.24 & 0.81 \\
\hline U-110 & 21.00 & 0.18 & $5.29 \mathrm{E}+05$ & $4.80 \mathrm{E}+05$ & 23.17 & 0.20 \\
\hline U-111 & 16.00 & 0.47 & $3.46 \mathrm{E}+06$ & $2.38 \mathrm{E}+06$ & 23.27 & 0.68 \\
\hline U-112 & 17.25 & 0.44 & $2.06 \mathrm{E}+05$ & $1.53 \mathrm{E}+05$ & 23.25 & 0.59 \\
\hline U-201 & 21.00 & 0.17 & $1.07 \mathrm{E}+04$ & $9.68 \mathrm{E}+03$ & 23.31 & 0.19 \\
\hline U-202 & 21.00 & 0.17 & $9.39 \mathrm{E}+03$ & $8.46 \mathrm{E}+03$ & 23.30 & 0.19 \\
\hline U-203 & 21.00 & 0.17 & $8.56 \mathrm{E}+03$ & $7.73 \mathrm{E}+03$ & 23.26 & 0.19 \\
\hline U-204 & 21.00 & 0.25 & $3.54 \mathrm{E}+03$ & $3.19 \mathrm{E}+03$ & 23.28 & 0.27 \\
\hline Totals & $12.83^{*}$ & $0.52^{*}$ & $5.88 E+08$ & $3.74 E+08$ & $20.20^{*}$ & $0.81^{*}$ \\
\hline & & & $\begin{array}{r}36 \% \mathrm{Gl} \\
\mathrm{Re}\end{array}$ & $\begin{array}{l}\text { Volume } \\
\text { on }\end{array}$ & & \\
\hline
\end{tabular}

* Average loadings over entire inventory. 
ORP-56322, Rev. 0

The Catholic University of America Vitreous State Laboratory
LAW Envelopes A and B Glass Formulations Testing to Increase Waste Loading Final Report, VSL-06R6900-1, Rev. 0

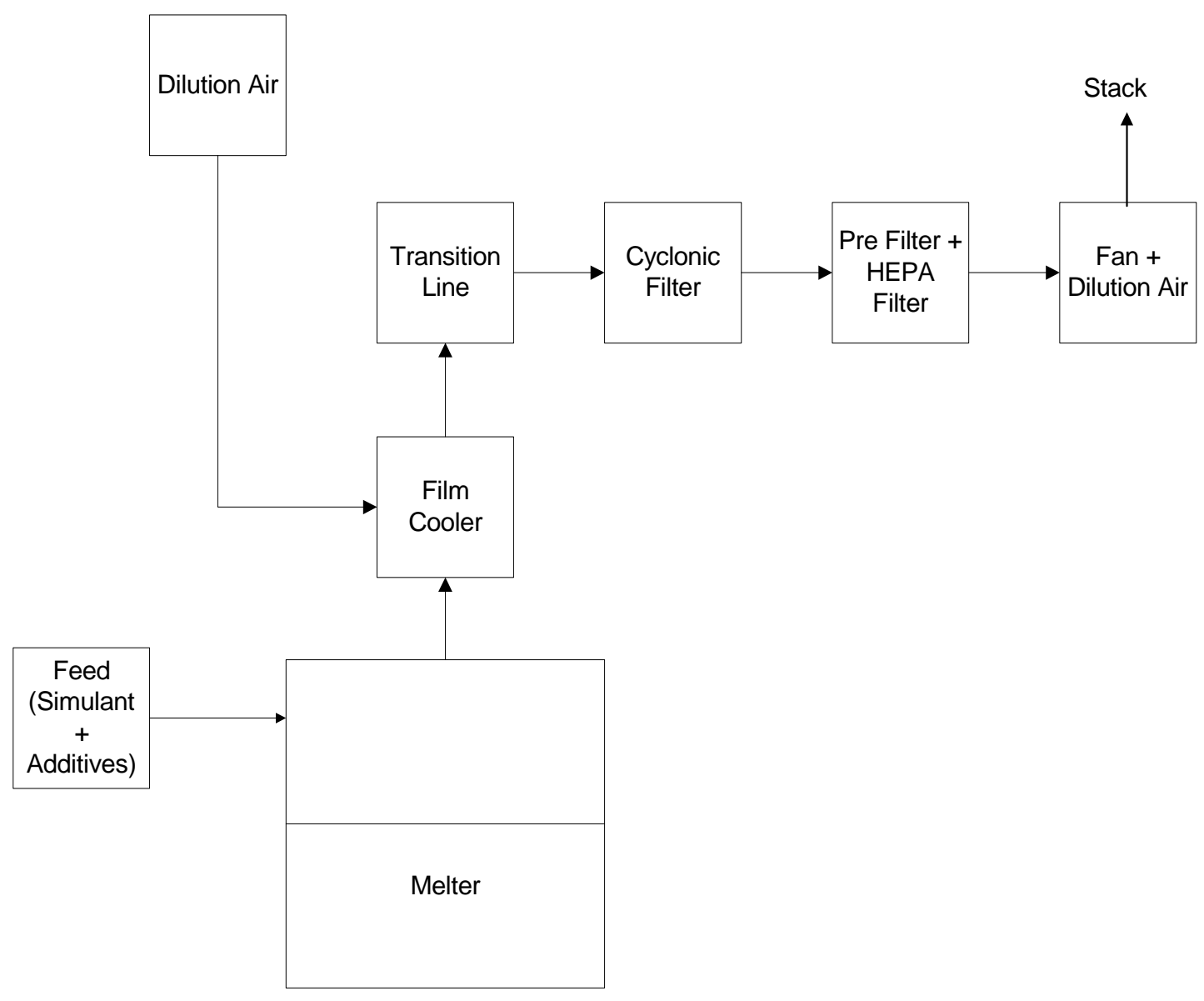

Figure 1.1. Schematic diagram of DuraMelter 100-WV vitrification system. 
ORP-56322, Rev. 0

The Catholic University of America Vitreous State Laboratory
LAW Envelopes A and B Glass Formulations Testing to Increase Waste Loading Final Report, VSL-06R6900-1, Rev. 0

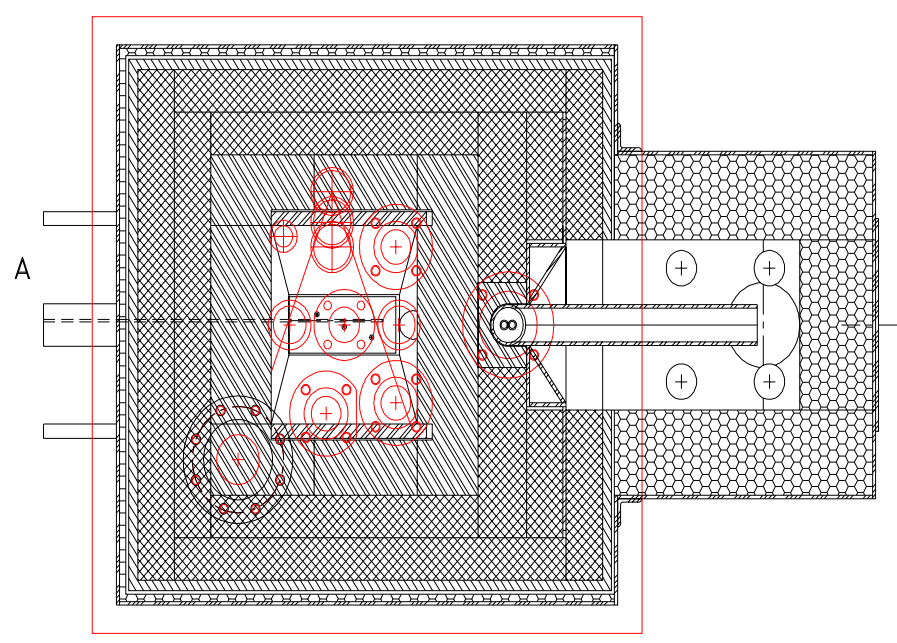

SECTION B-B

(BACKGROUND OMITED)

Figure 1.2(a). Cross-section through the DM100-WV melter_ Plan View. 
ORP-56322, Rev. 0

The Catholic University of America Vitreous State Laboratory
LAW Envelopes A and B Glass Formulations Testing to Increase Waste Loading Final Report, VSL-06R6900-1, Rev. 0

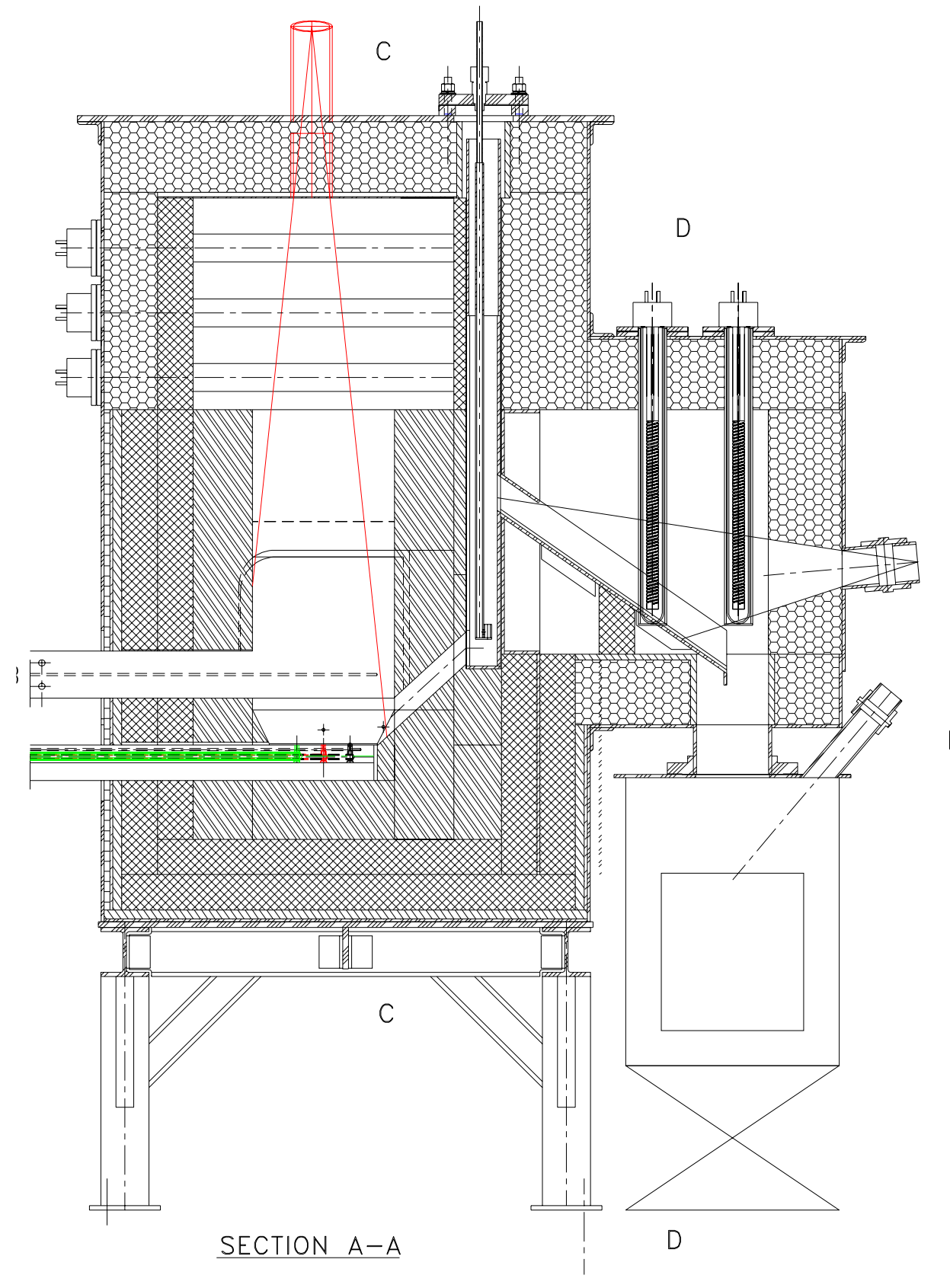

Figure 1.2(b). Cross-section through the DM100-WV melter-Section AA. 
ORP-56322, Rev. 0

The Catholic University of America Vitreous State Laboratory
LAW Envelopes A and B Glass Formulations Testing to Increase Waste Loading Final Report, VSL-06R6900-1, Rev. 0

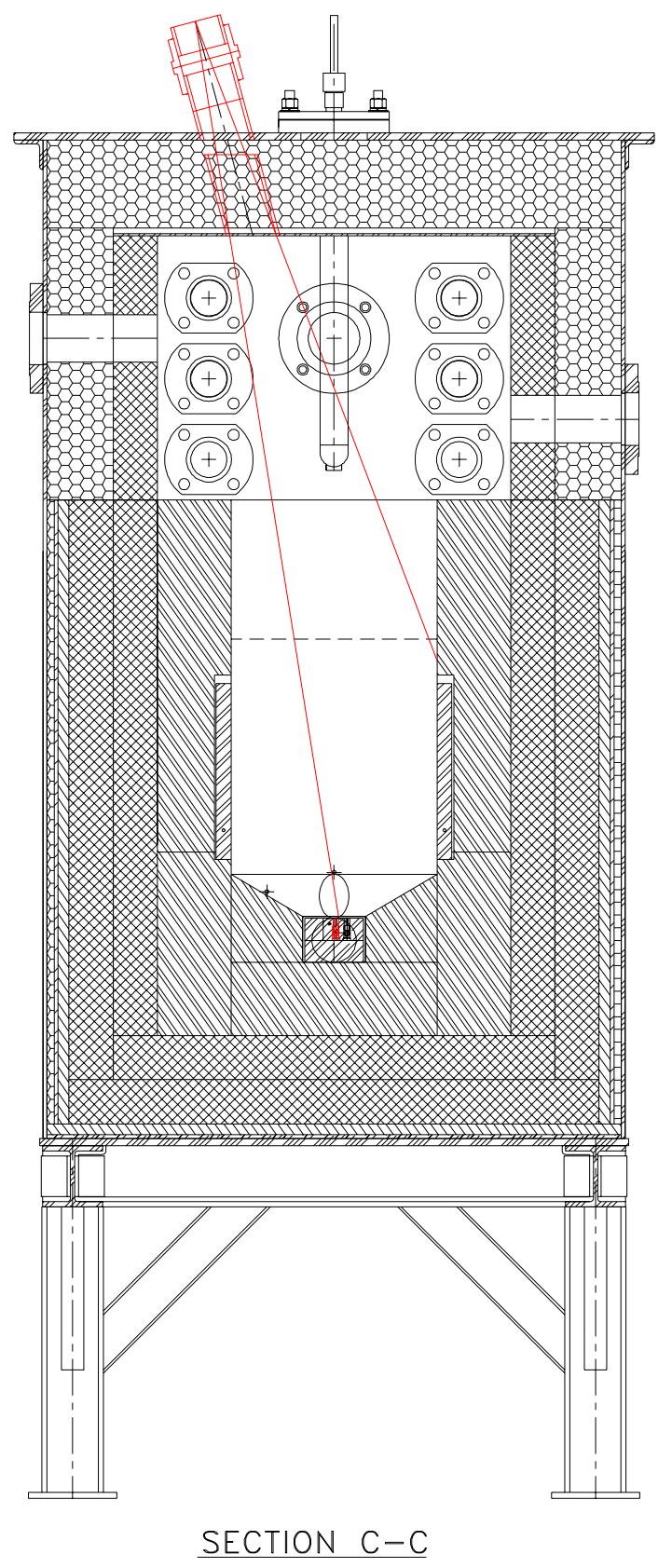

Figure 1.2(c). Cross-section through the DM100-WV melter-Section CC. 


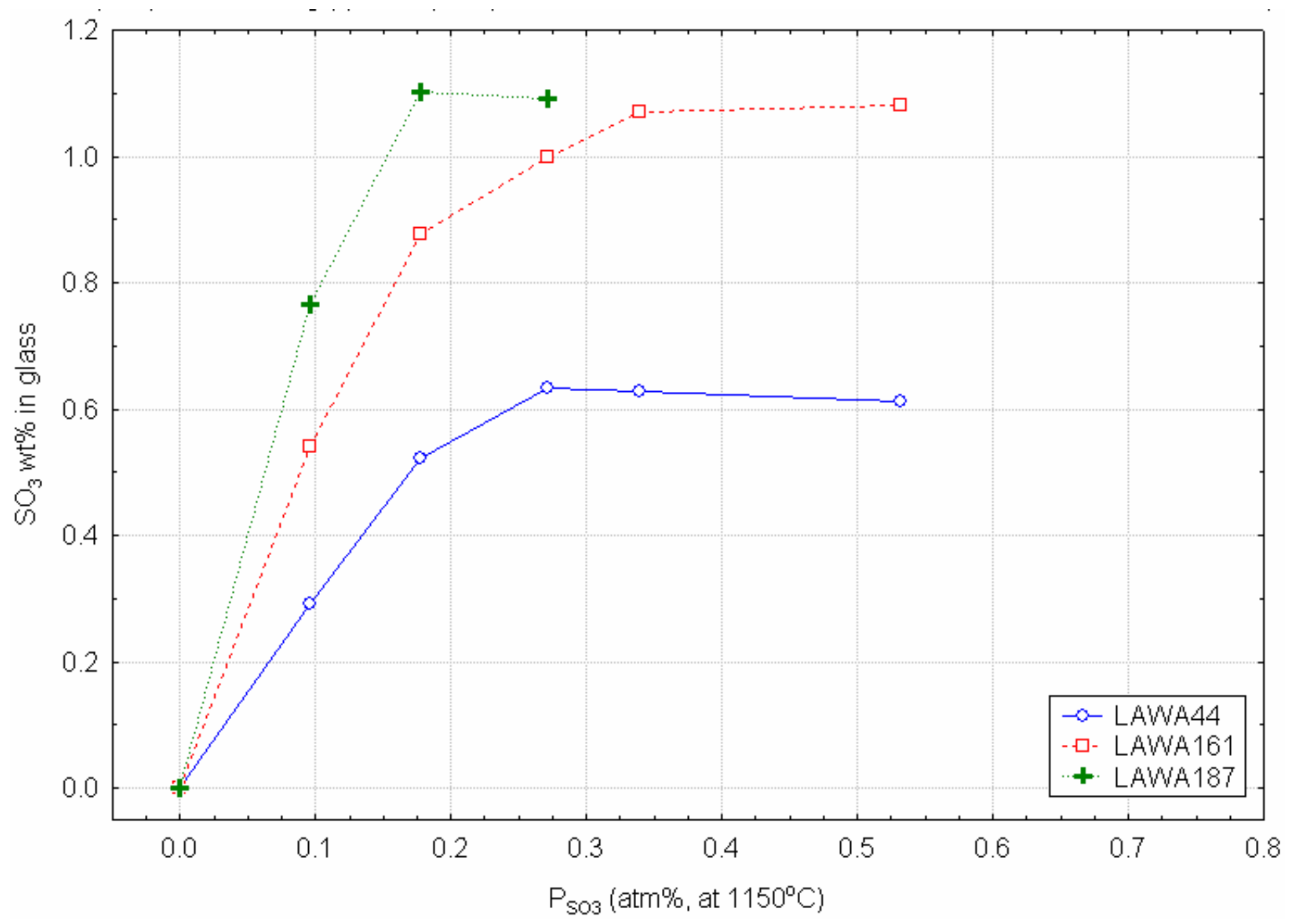

Figure 2.1. Results of $\mathrm{SO}_{2} / \mathrm{O}_{2}$ gas bubbling tests on the new LAW Envelope A glass LAWA187, the previous ORP Envelope A glass LAWA161, and a WTP baseline Envelope A glass composition LAWA44 at $1150^{\circ} \mathrm{C}$ showing the partial pressure of $\mathrm{SO}_{3}$ vs. the $\mathrm{SO}_{3}$ concentration in the glass melt. The horizontal portions indicate the solubility limits while the slopes at lower concentrations provide measures of the activity coefficient of $\mathrm{SO}_{3}$ in the melt. 


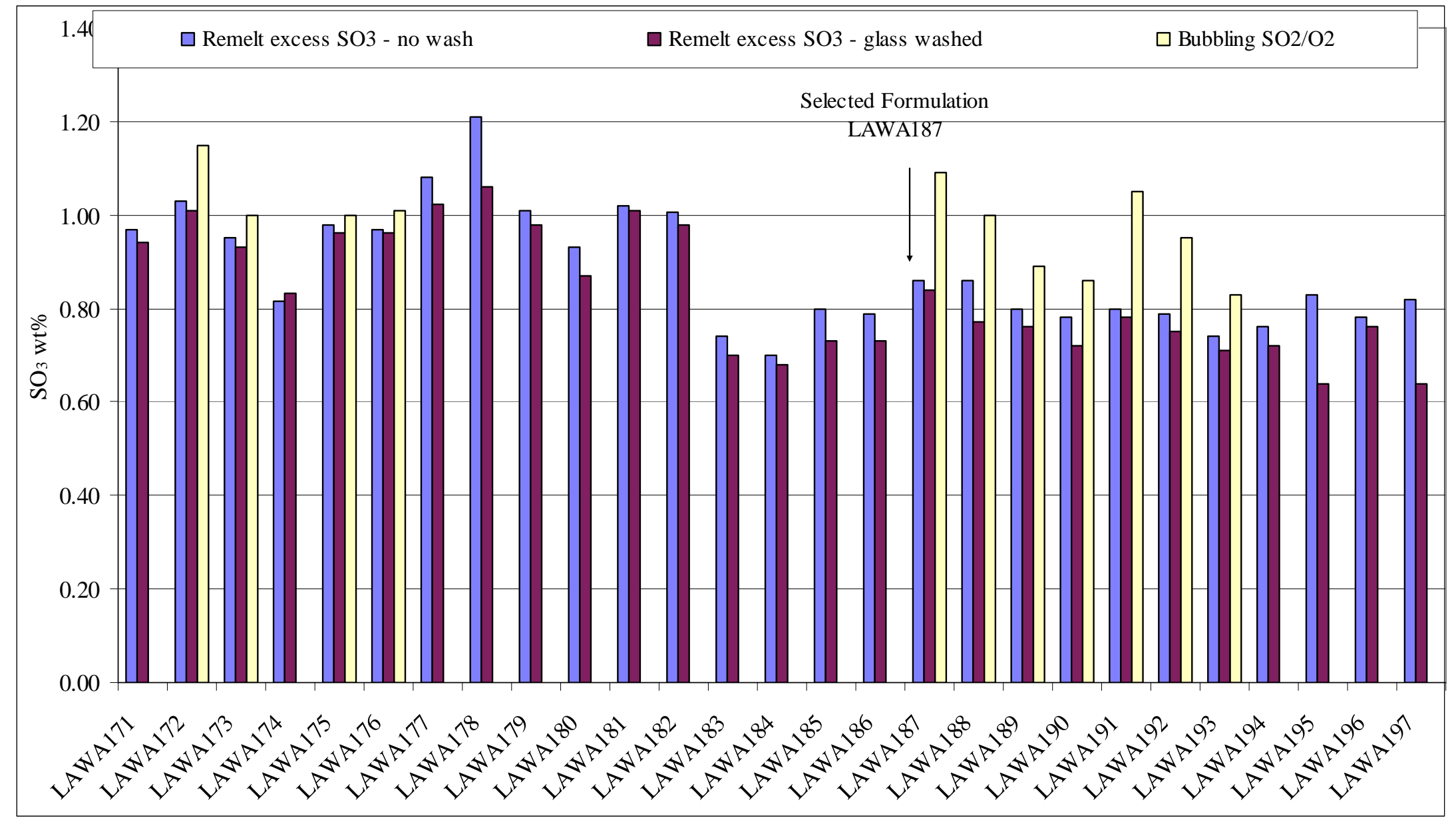

Figure 2.2. Measured sulfate solubility by $\mathrm{SO}_{2} / \mathrm{O}_{2}$ gas bubbling and by remelting with excess $\mathrm{SO}_{3}$ for twenty seven new $\mathrm{LAW}$ Envelope $\mathrm{A}$ crucible glasses. 


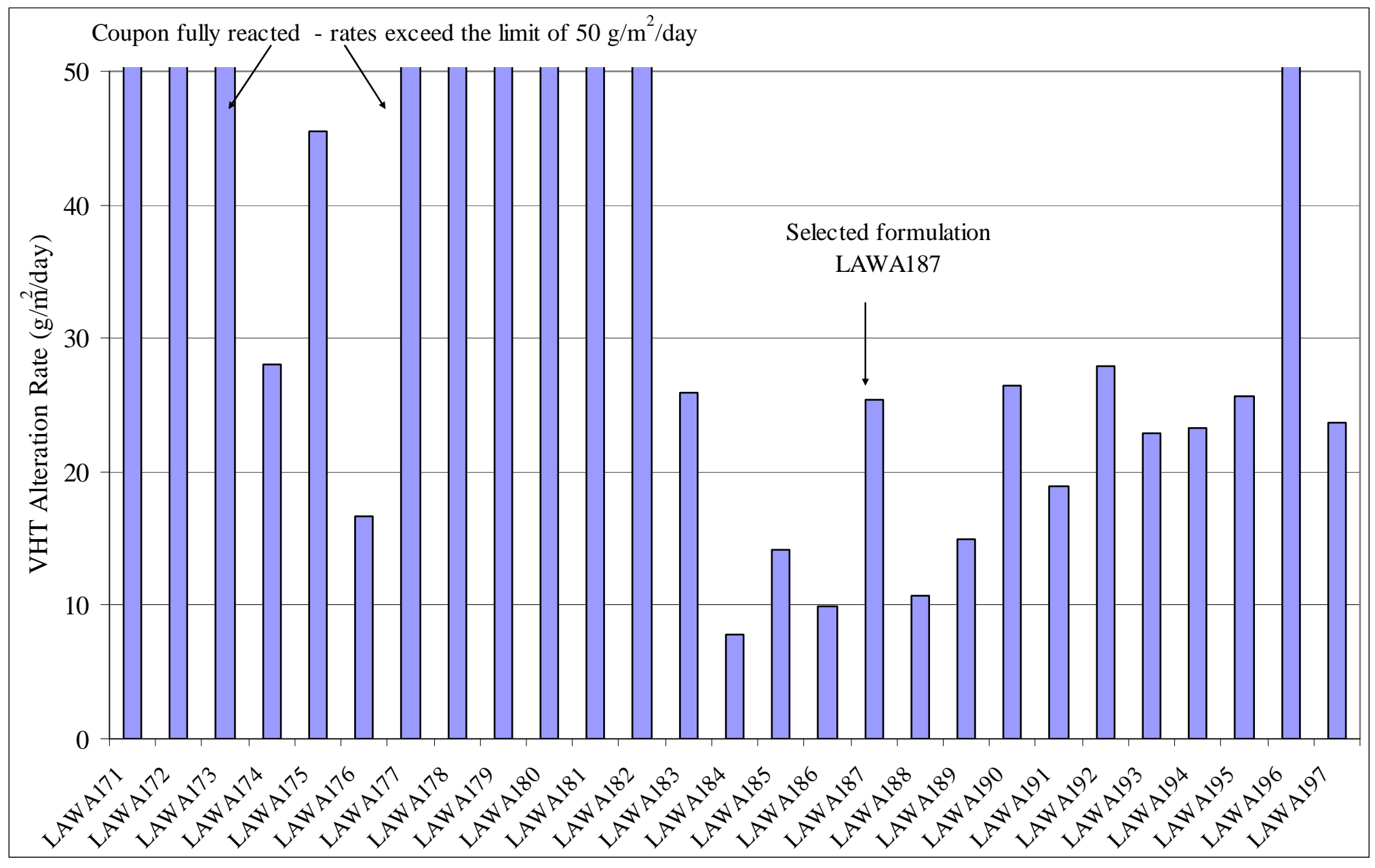

Figure 2.3. VHT results for twenty seven new LAW Envelope A crucible glasses. 


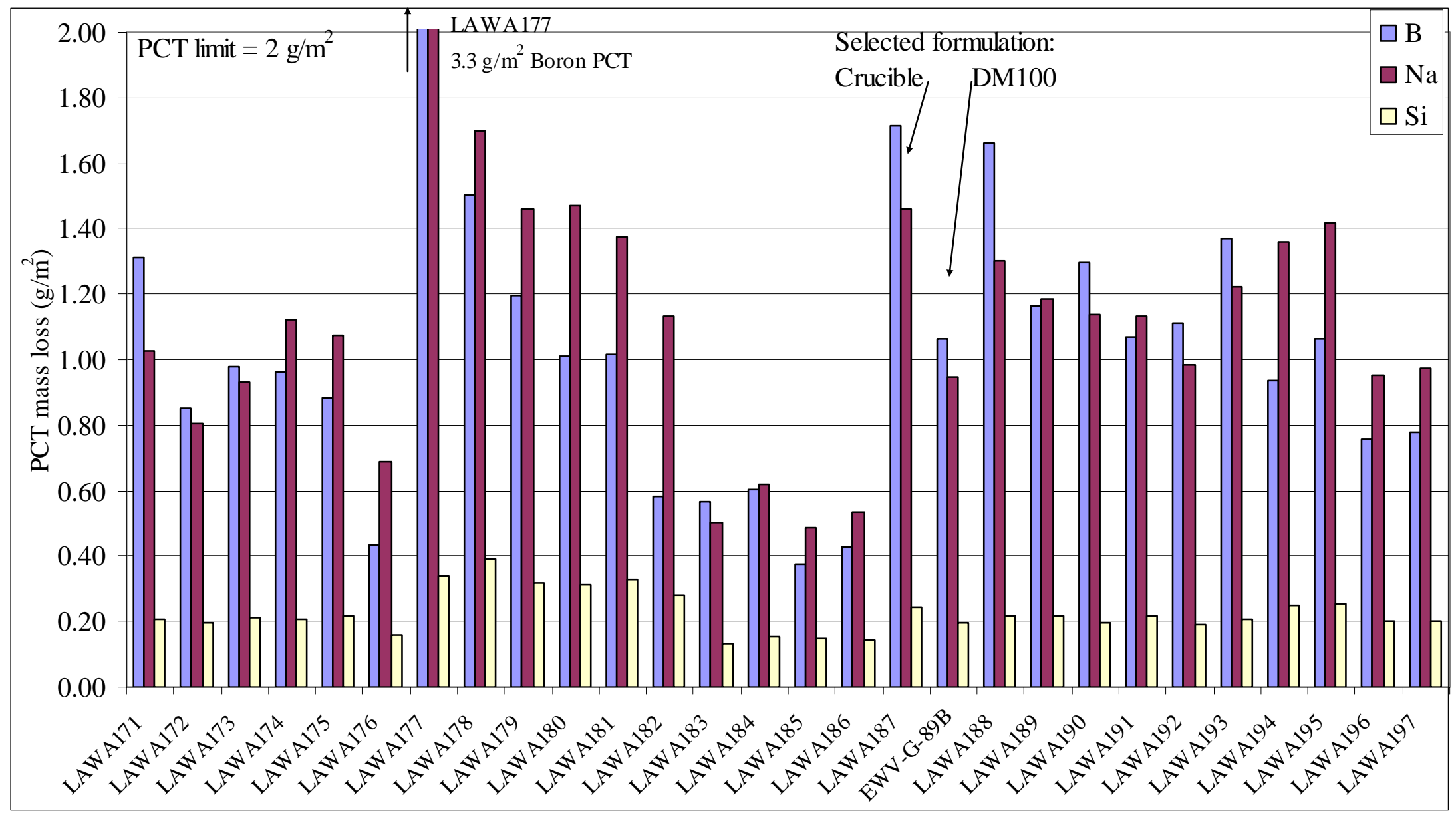

Figure 2.4. Normalized PCT responses for twenty seven new LAW Envelope A crucible glasses. 


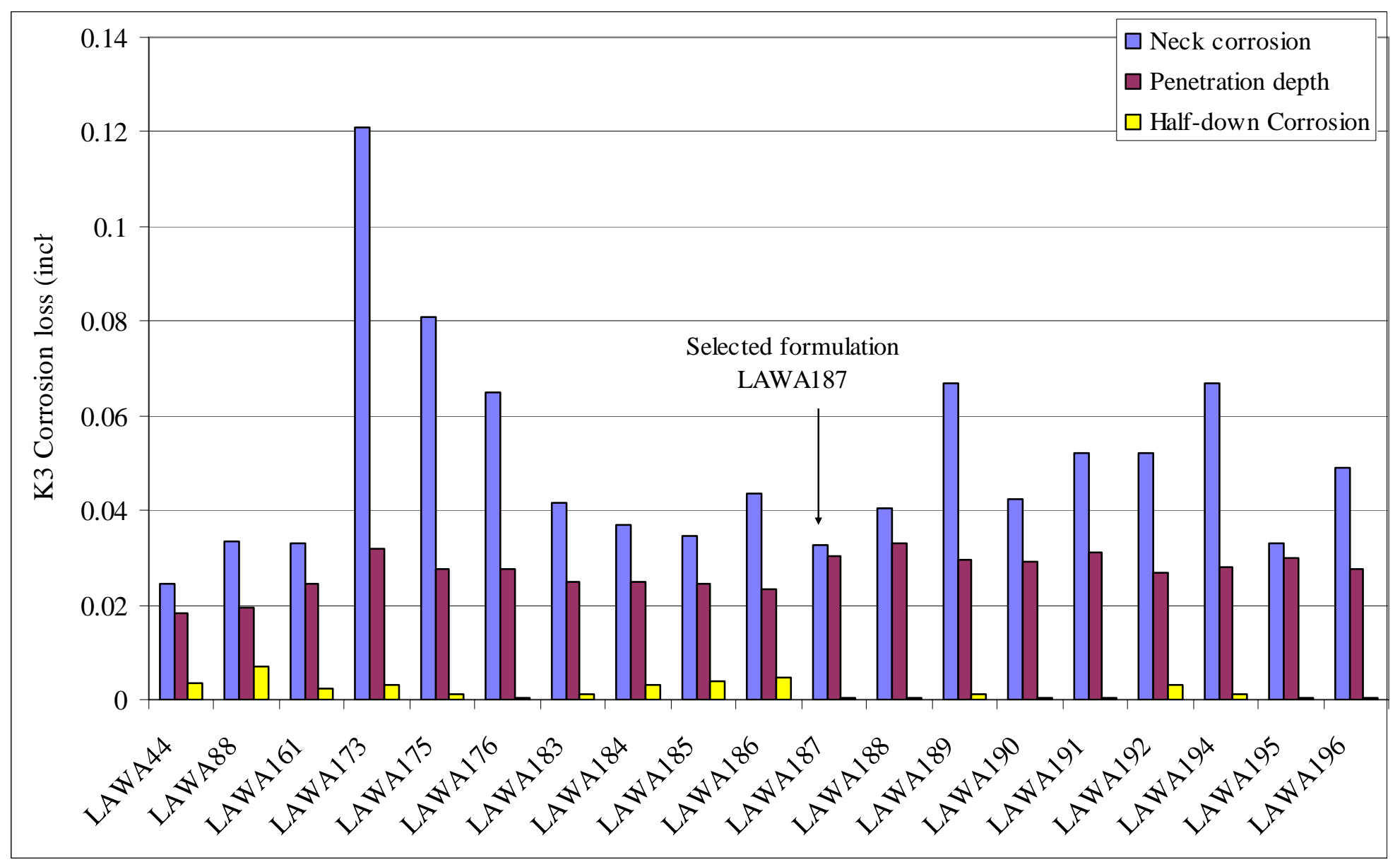

Figure 2.5. K3 Corrosion results for sixteen new LAW Envelope A crucible glasses and three old LAW formulations. 


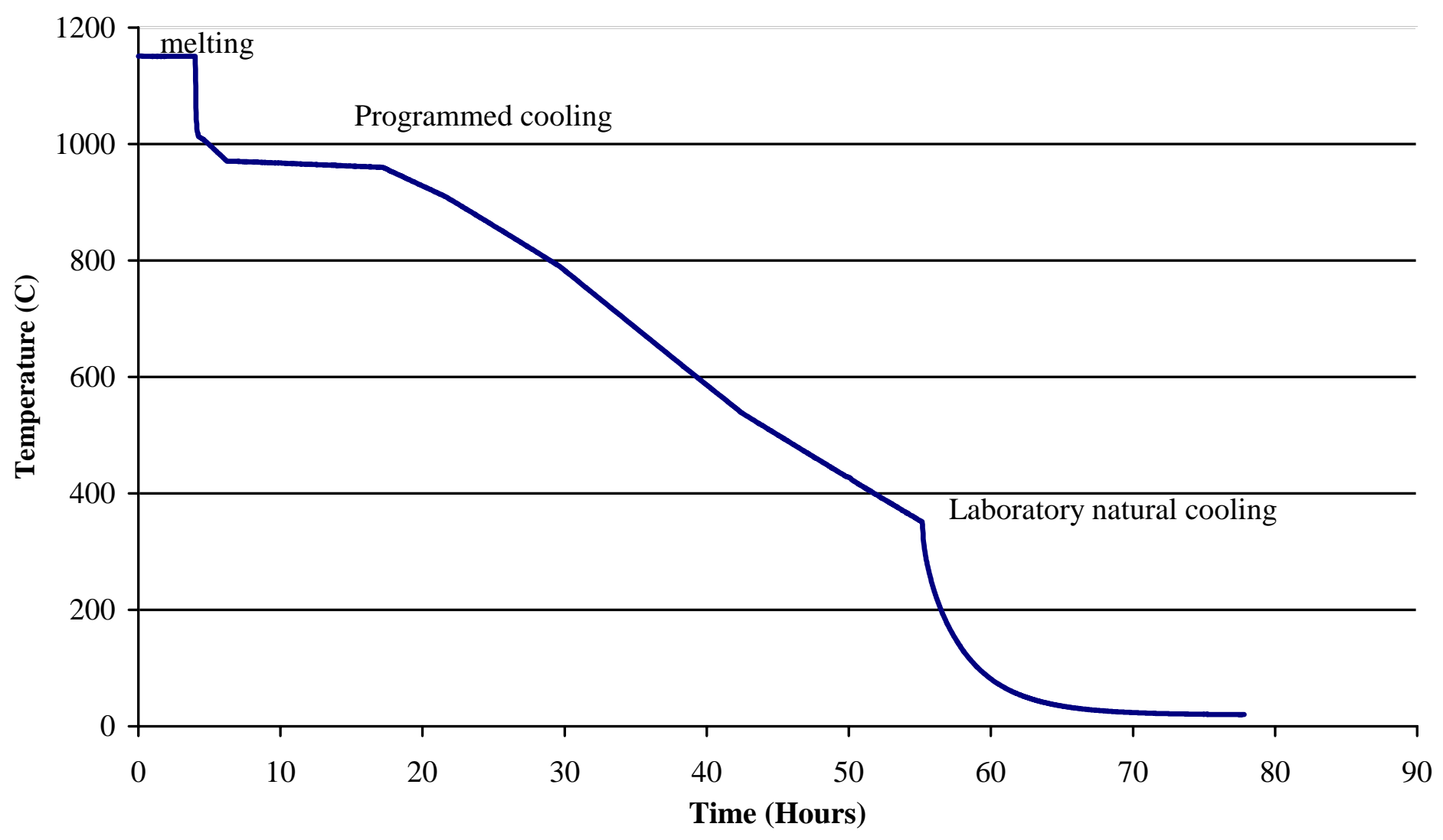

Figure 2.6. Centerline canister cooling curve used for heat treatment of LAWA187CCC, LAWB99CCC, and Envelope A melter glass EWV89CCC. 

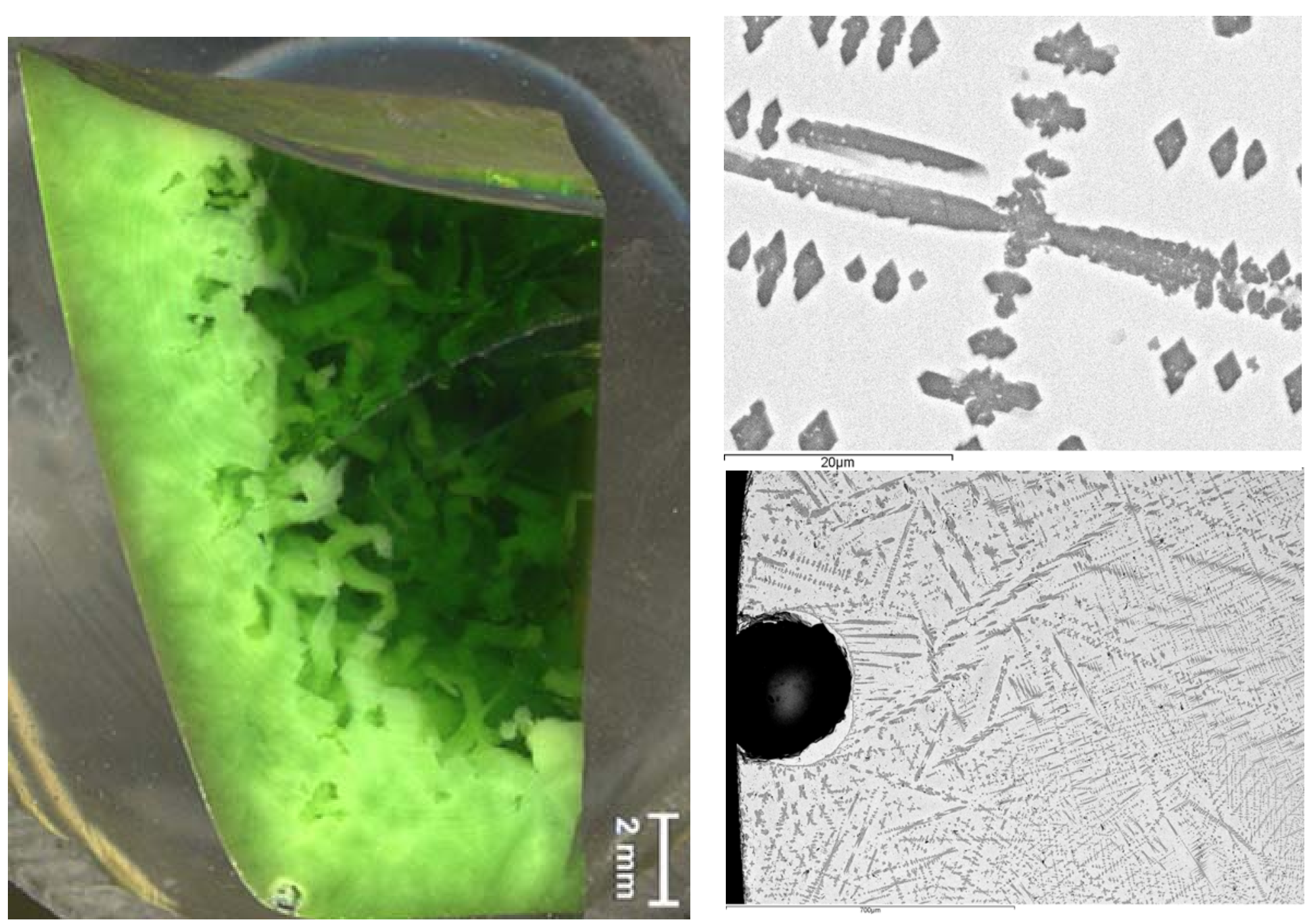

Figure 2.7. Optical and SEM images of sample LAWA187CCC. (a). Optical image of the cross section of a 1" deep polished crucible glass sample shows sodalite phase nucleating at the crucible contact surfaces and extending about 4-5 mm into the bulk of the glass. (b \& c). low magnification (X15) and high magnification (X400) SEM images of the sodalite crystals. 


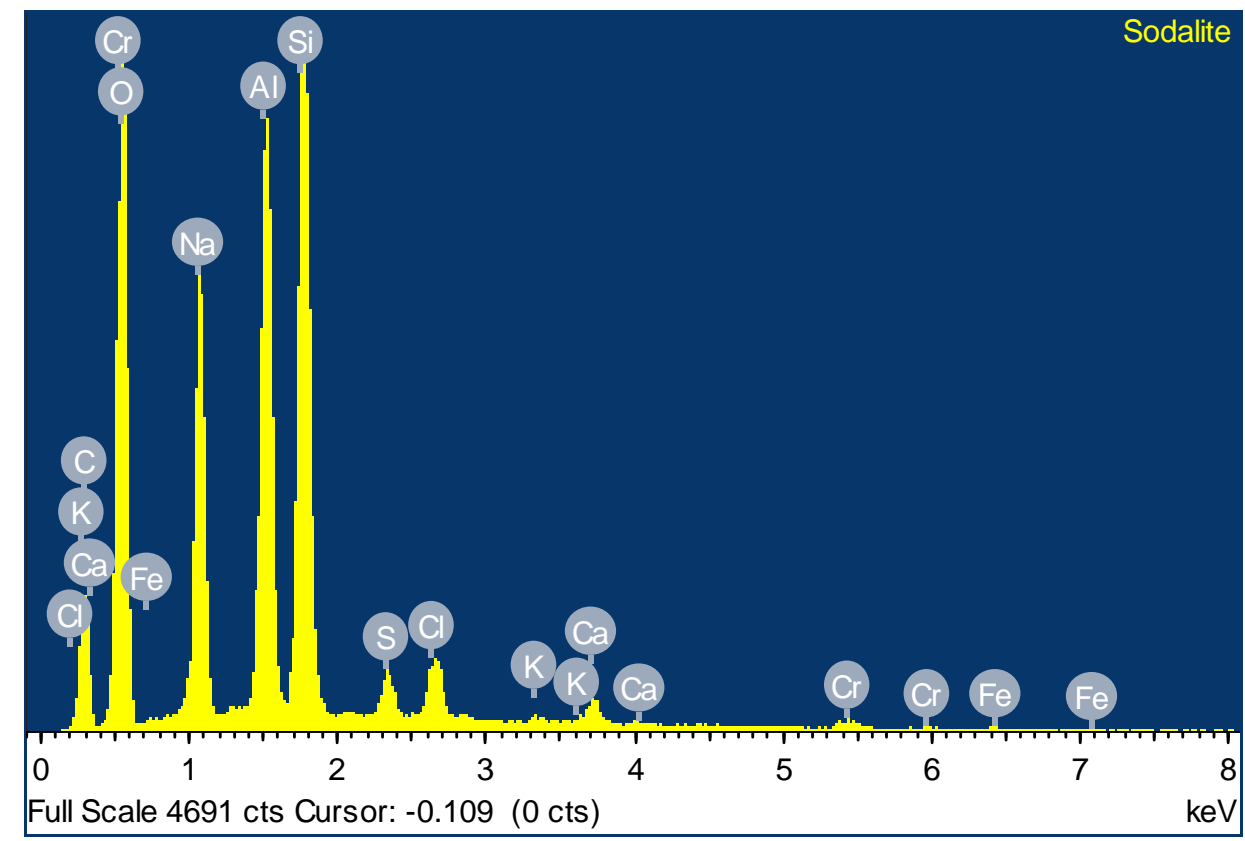

\begin{tabular}{l|llll}
\hline Element & Weight\% & Atomic\% & Formula & Compd\% \\
& & & & \\
Na K & 13.61 & 12.33 & $\mathrm{Na} 2 \mathrm{O}$ & 18.35 \\
$\mathrm{Al} \mathrm{K}$ & 14.92 & 11.51 & $\mathrm{Al2O} 3$ & 28.19 \\
$\mathrm{Si} \mathrm{K}$ & 19.88 & 14.74 & $\mathrm{SiO} 2$ & 42.54 \\
$\mathrm{~S} \mathrm{~K}$ & 1.37 & 0.89 & $\mathrm{SO} 3$ & 3.42 \\
$\mathrm{Cl} \mathrm{K}$ & 3.00 & 1.76 & & 0.00 \\
$\mathrm{~K} \mathrm{~K}$ & 0.28 & 0.15 & $\mathrm{~K} 2 \mathrm{O}$ & 0.33 \\
$\mathrm{Ca} \mathrm{K}$ & 1.48 & 0.77 & $\mathrm{CaO}$ & 2.07 \\
$\mathrm{Cr} \mathrm{K}$ & 0.97 & 0.39 & $\mathrm{Cr} 2 \mathrm{O} 3$ & 1.42 \\
Fe K & 0.48 & 0.18 & $\mathrm{Fe} 2 \mathrm{O} 3$ & 0.68 \\
O & 44.01 & 57.28 & & \\
Totals & 100.00 & & & \\
\hline
\end{tabular}

Figure 2.8. EDS analysis of sodalite crystals in a sample of LAWA187CCC. 


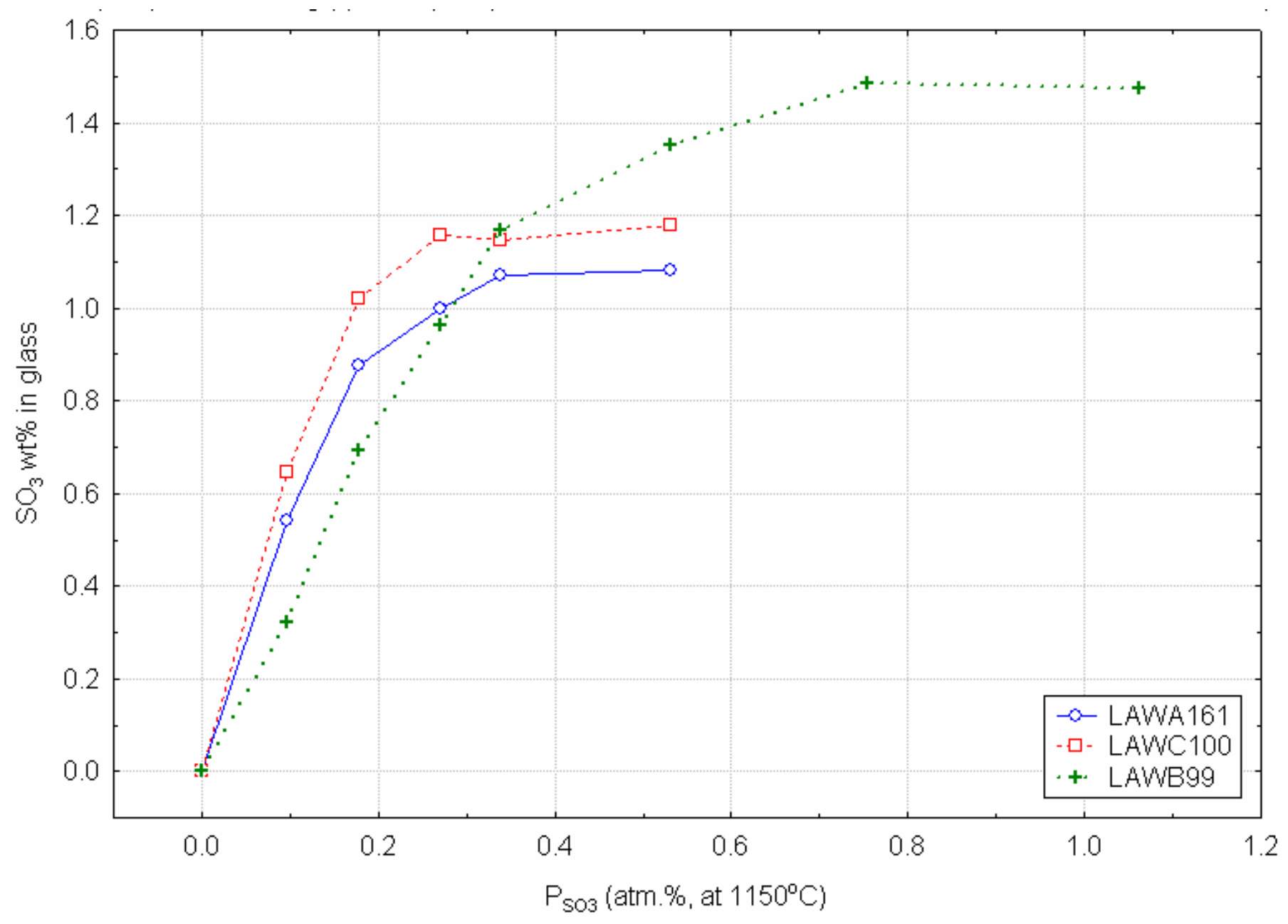

Figure 2.9. Results of $\mathrm{SO}_{2} / \mathrm{O}_{2}$ gas bubbling tests on the new LAW Envelope B glass LAWB99, previous ORP Envelope A glass LAWA161, and ORP Envelope $\mathrm{C}$ glass LAWC100 at $1150^{\circ} \mathrm{C}$ showing the partial pressure of $\mathrm{SO}_{3}$ vs. the $\mathrm{SO}_{3}$ concentration in the glass melt. The horizontal portions indicate the solubility limits while the slopes at lower concentrations provide measures of the activity coefficient of $\mathrm{SO}_{3}$ in the melt. 


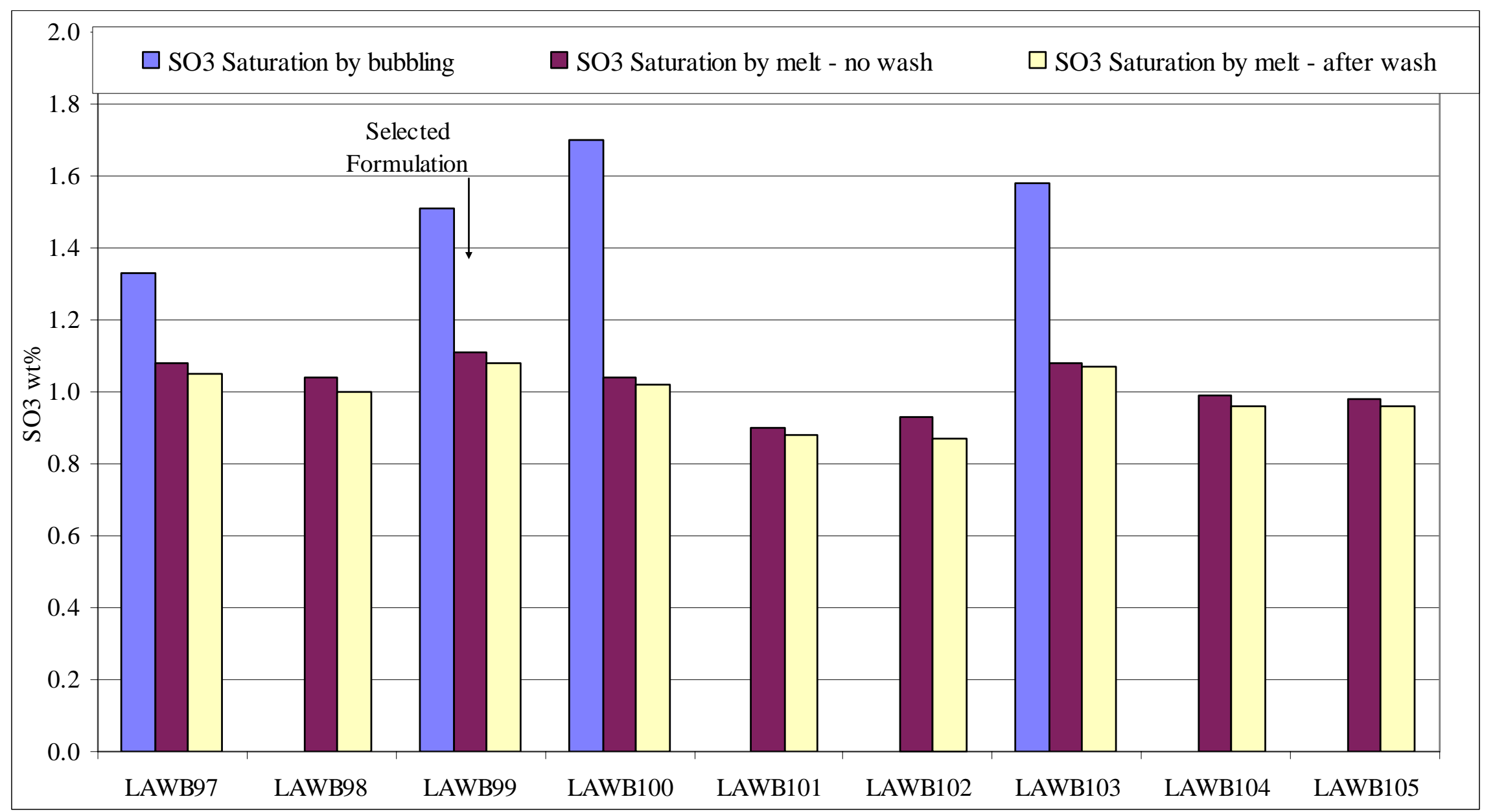

Figure 2.10. Measured sulfate solubility by $\mathrm{SO}_{2} / \mathrm{O}_{2}$ gas bubbling and by remelting with excess $\mathrm{SO}_{3}$ for nine new $\mathrm{LAW} \mathrm{Envelope} \mathrm{B}$ crucible glasses. 


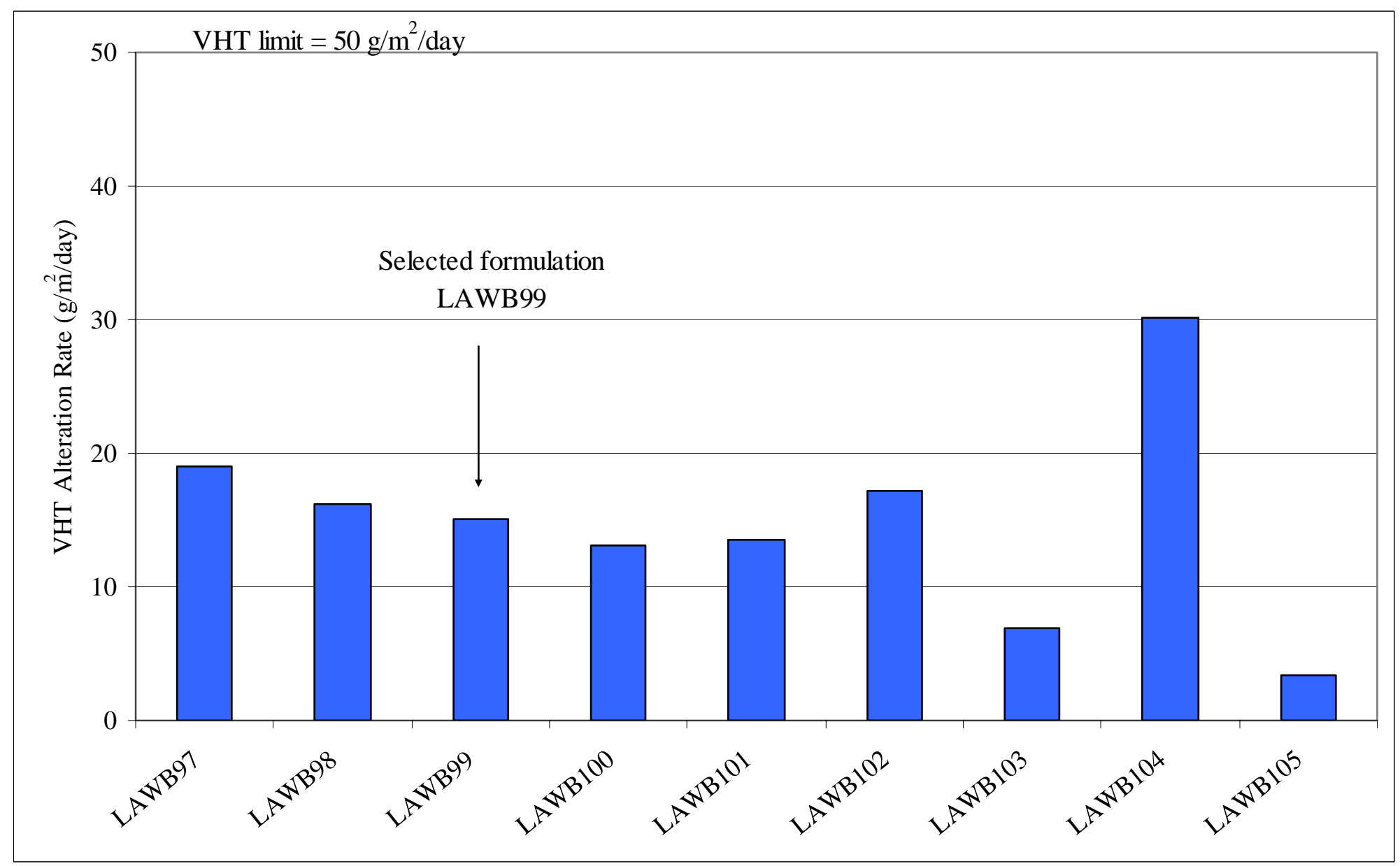

Figure 2.11. VHT results for nine new LAW Envelope B crucible glasses. 


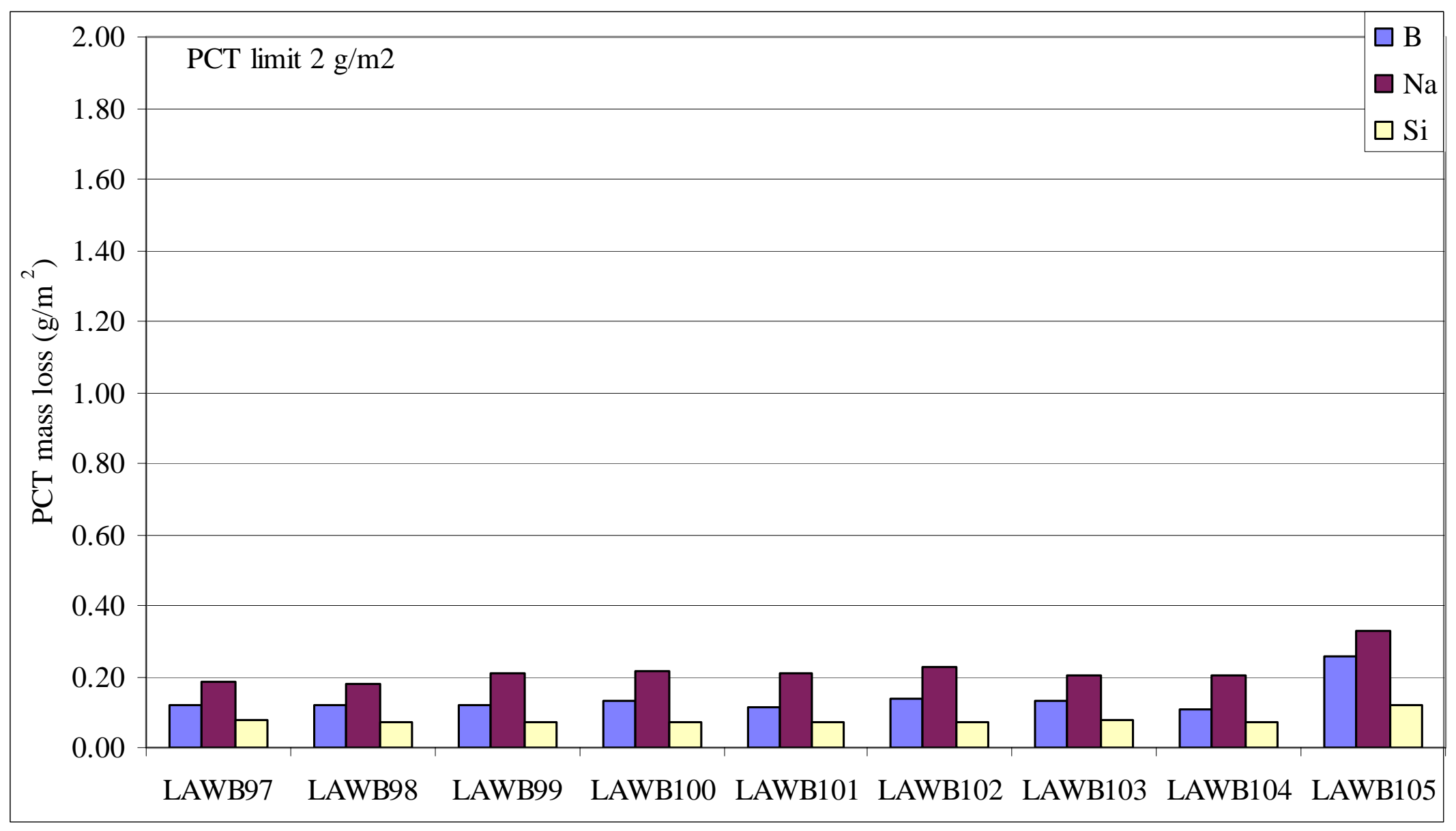

Figure 2.12. Normalized PCT responses for nine new LAW Envelope B crucible glasses. 


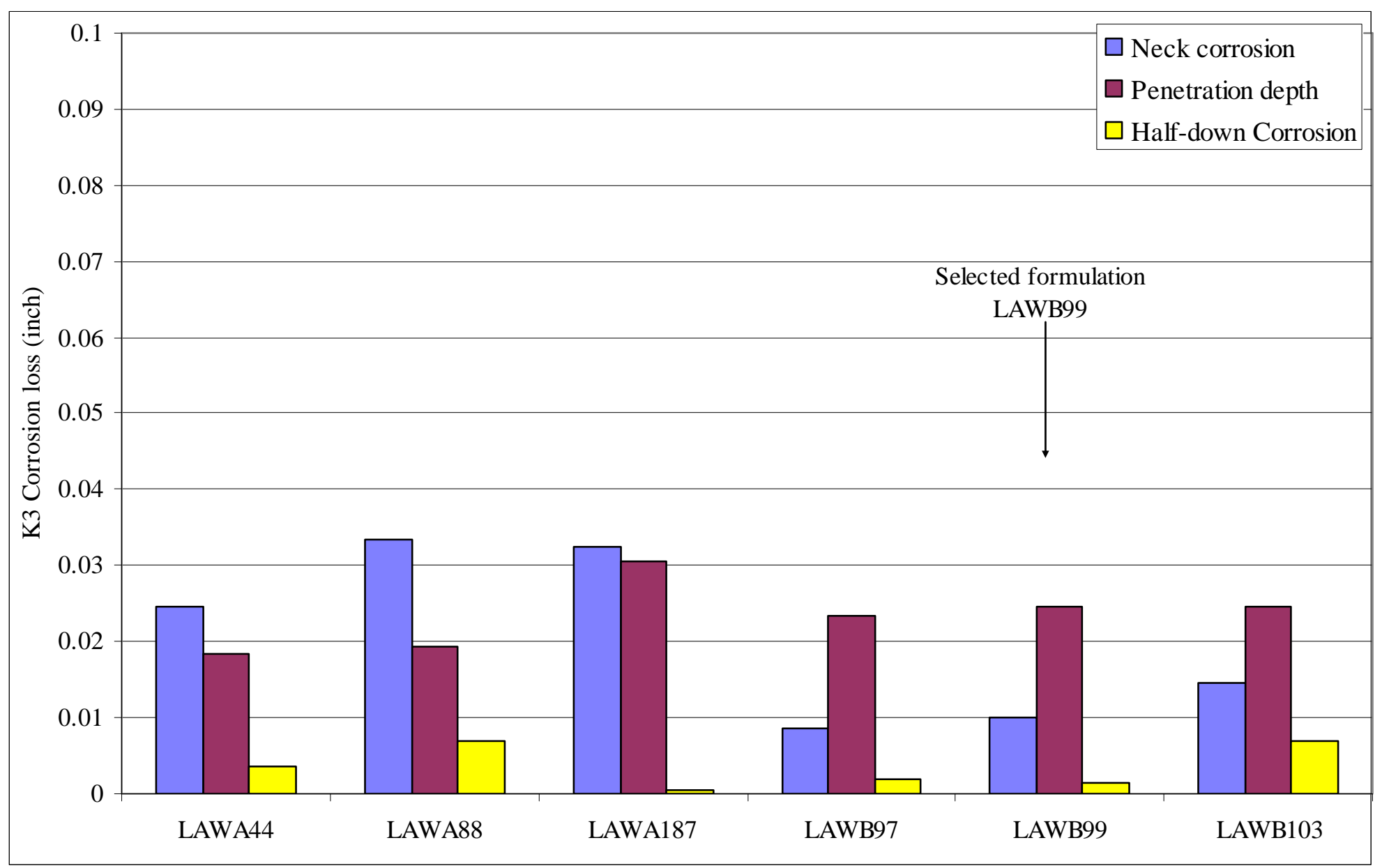

Figure 2.13. K3 Corrosion results for three new LAW Envelope B crucible glasses, LAWA187 and two old WTP LAW formulations. 


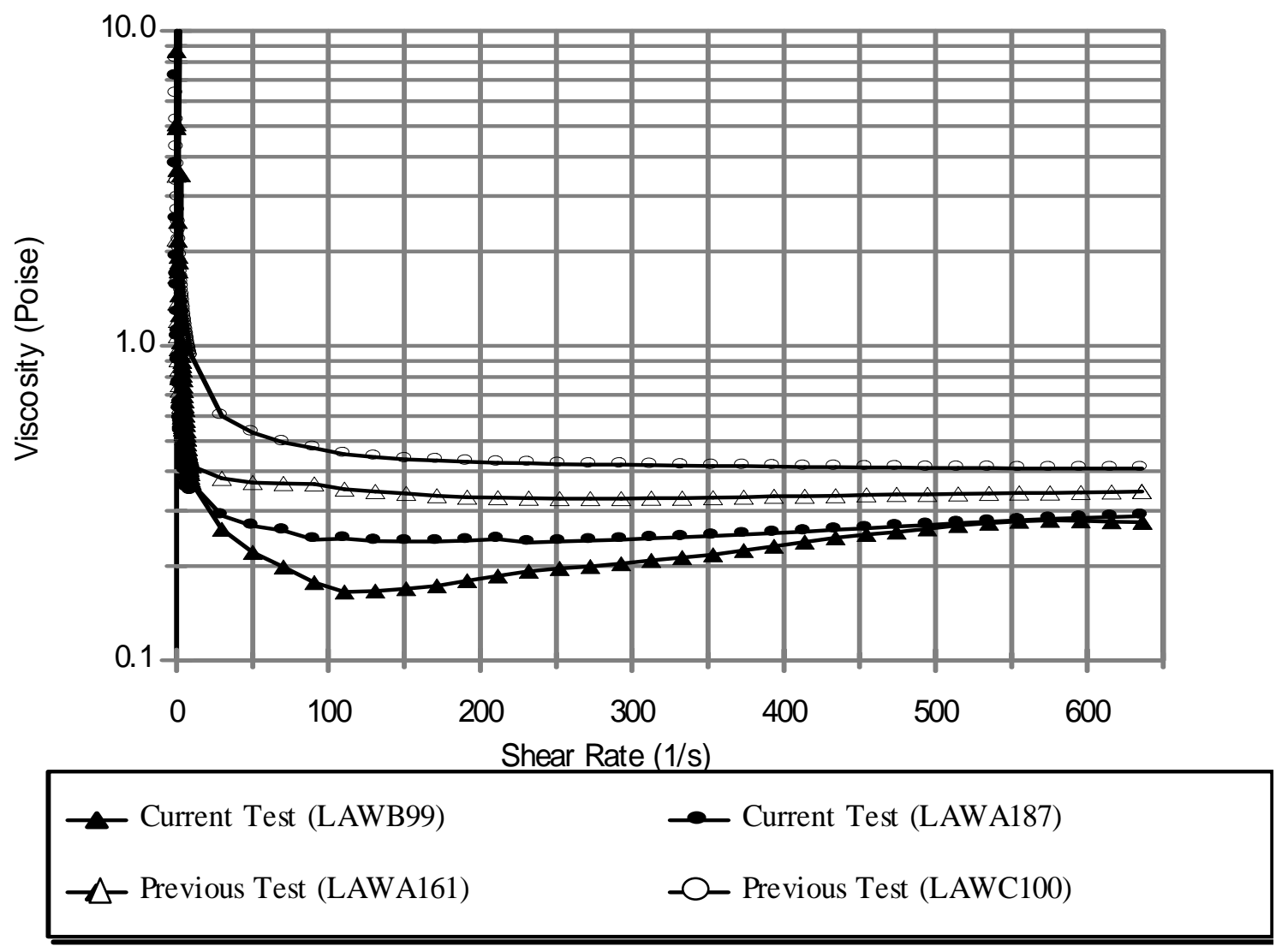

Figure 2.14. Measured viscosity of LAW melter feed samples. 


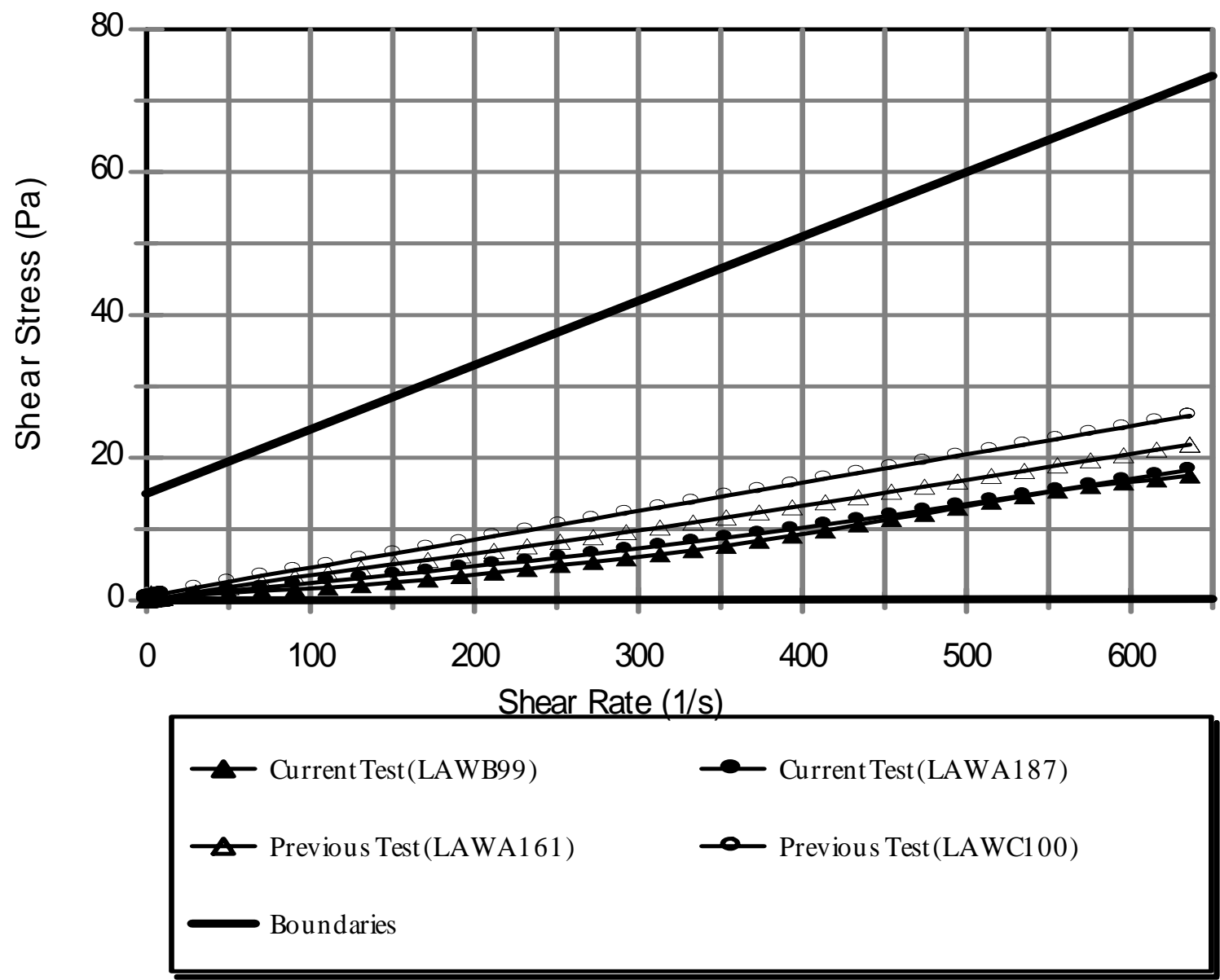

Figure 2.15. Comparison of measured feed rheology with proposed WTP bounds (bounds from WTP-RPT-075, Rev. 0, Feb. 2003). 


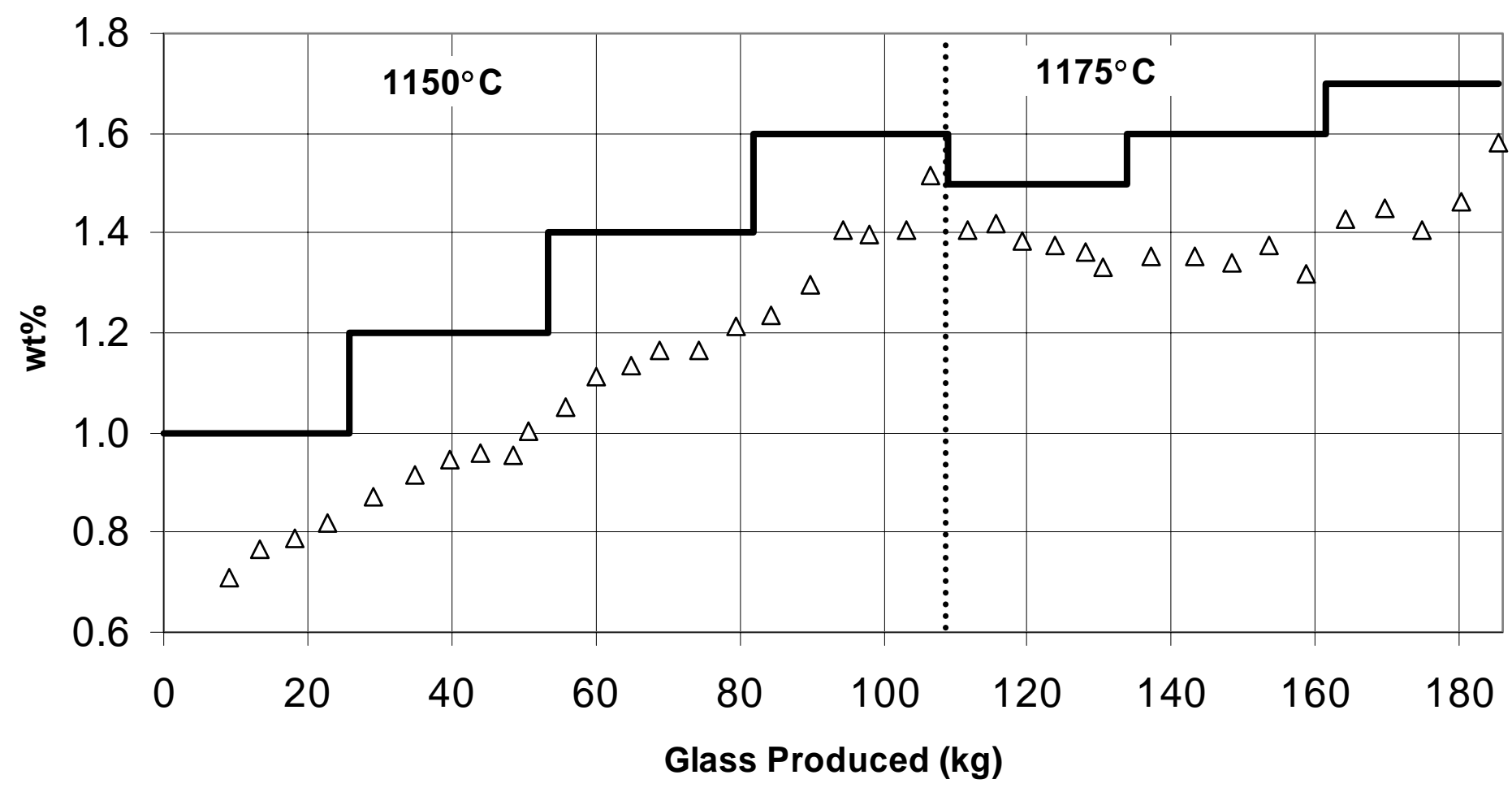

$\triangle$ Measured SO3 - Target SO3

Figure 3.1.a. XRF analysis of sulfur in DM10 LAWB product glasses. 


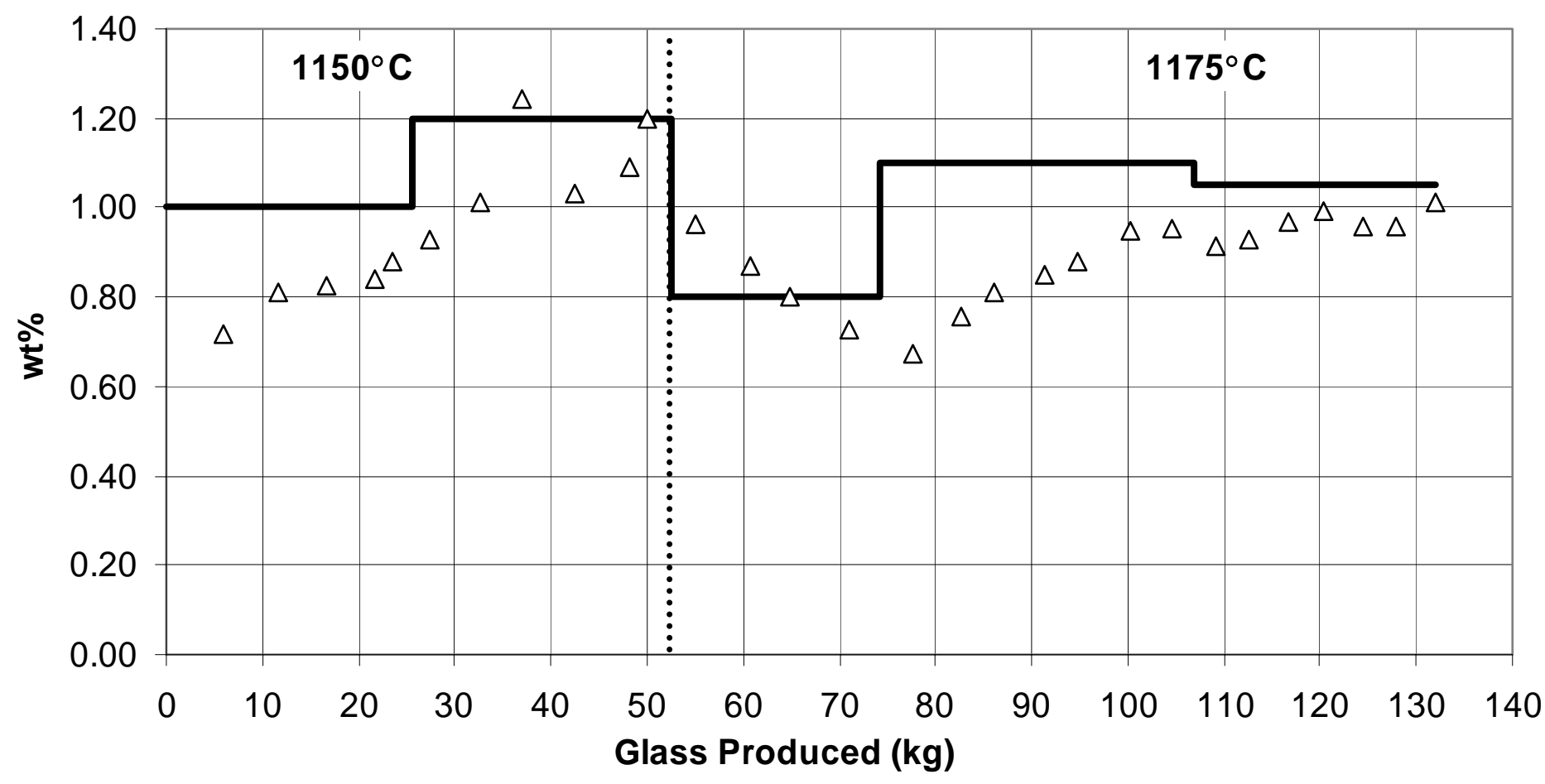

$\triangle$ Measured SO3 - Target SO3

Figure 3.1.b. XRF analysis of sulfur in DM10 LAWA product glasses. 


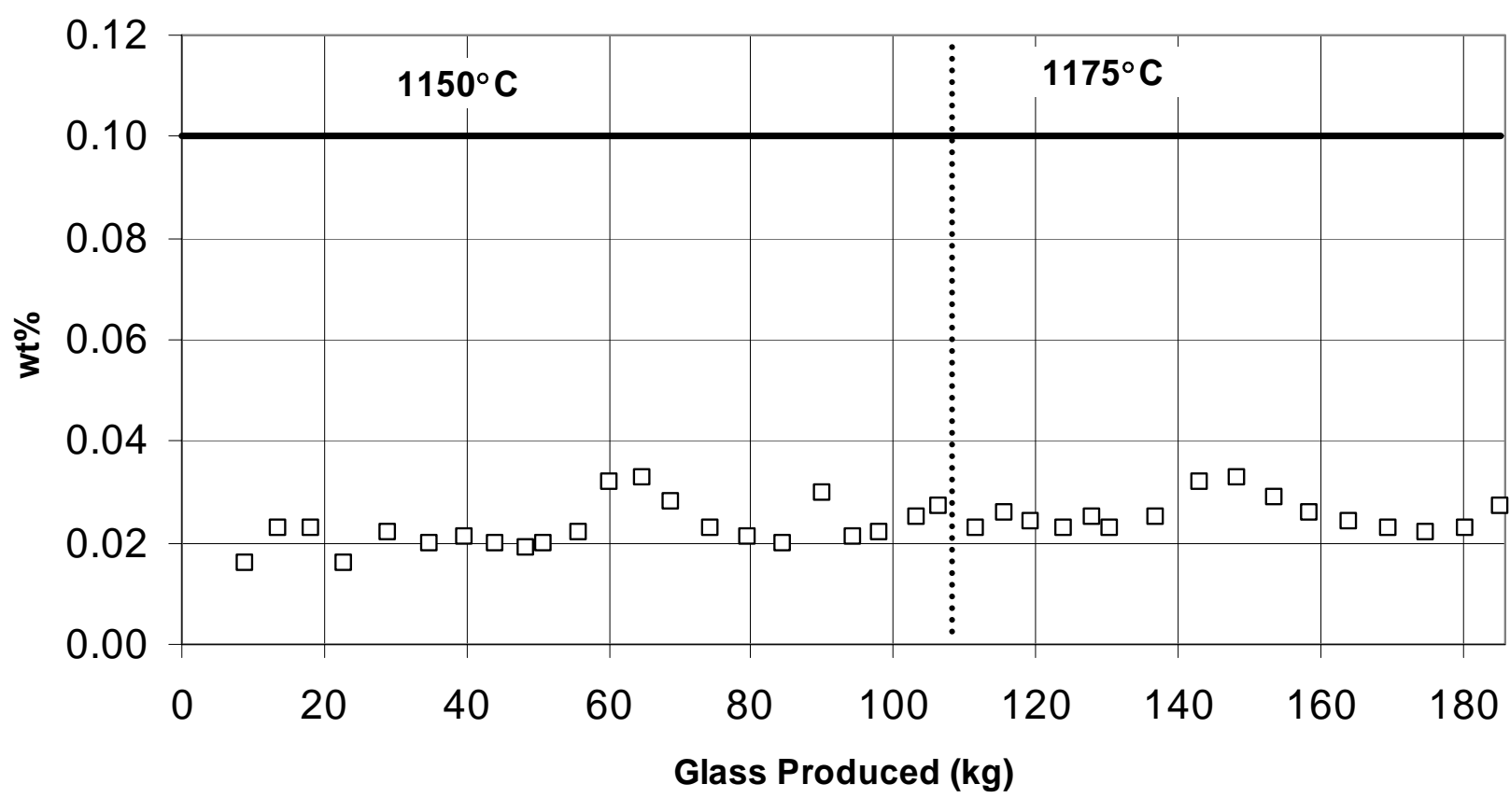

$\square$ Measured lodine $\longrightarrow$ Target lodine

Figure 3.2.a. XRF analysis of iodine in DM10 LAWB product glasses. 


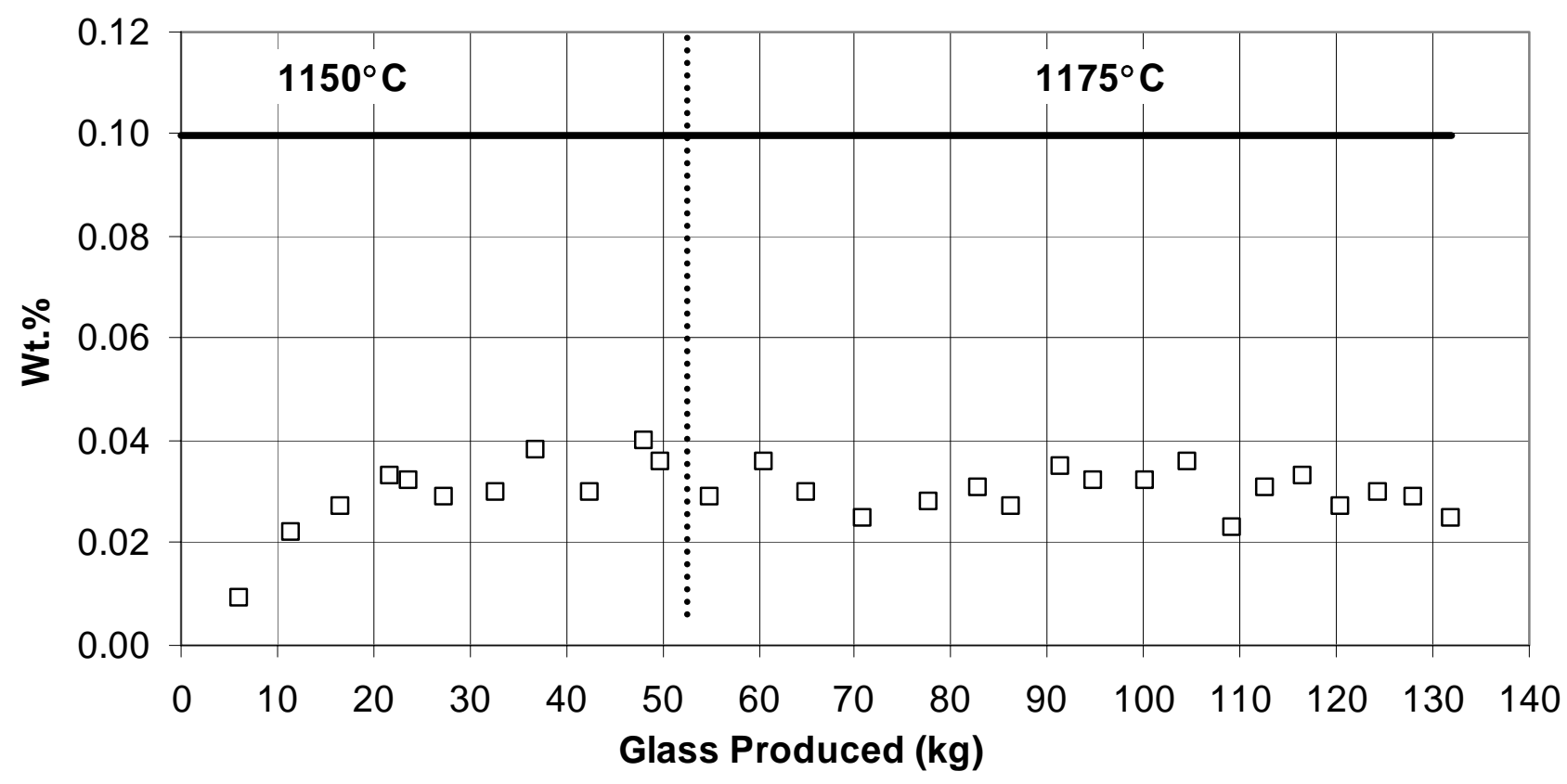

$\square$ Measured lodine $\longrightarrow$ Target lodine

Figure 3.2.b. XRF analysis of iodine in DM10 LAWA product glasses. 


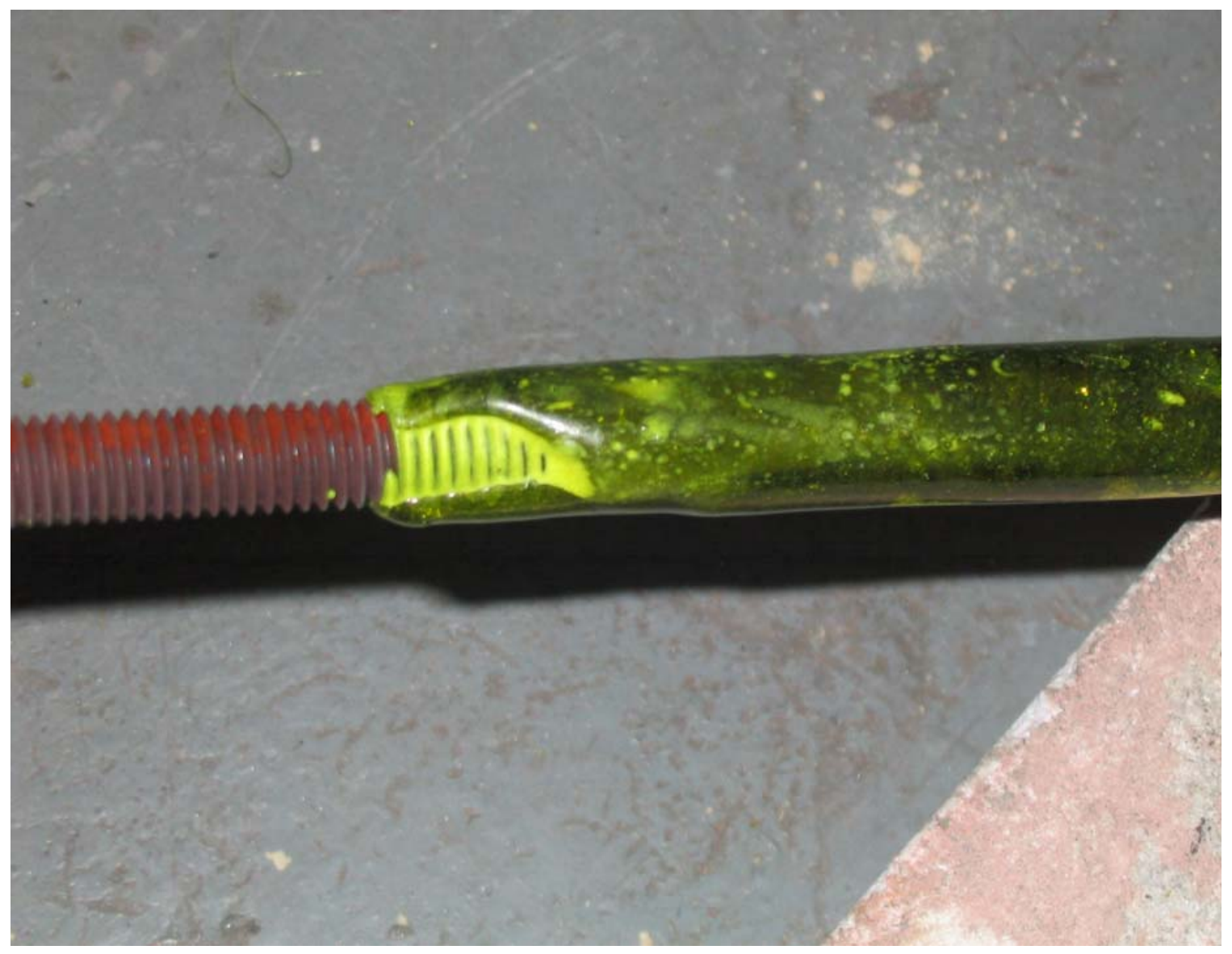

Figure 3.3. Secondary sulfur phases on dip samples from LAWA DM10 Test A1B. 


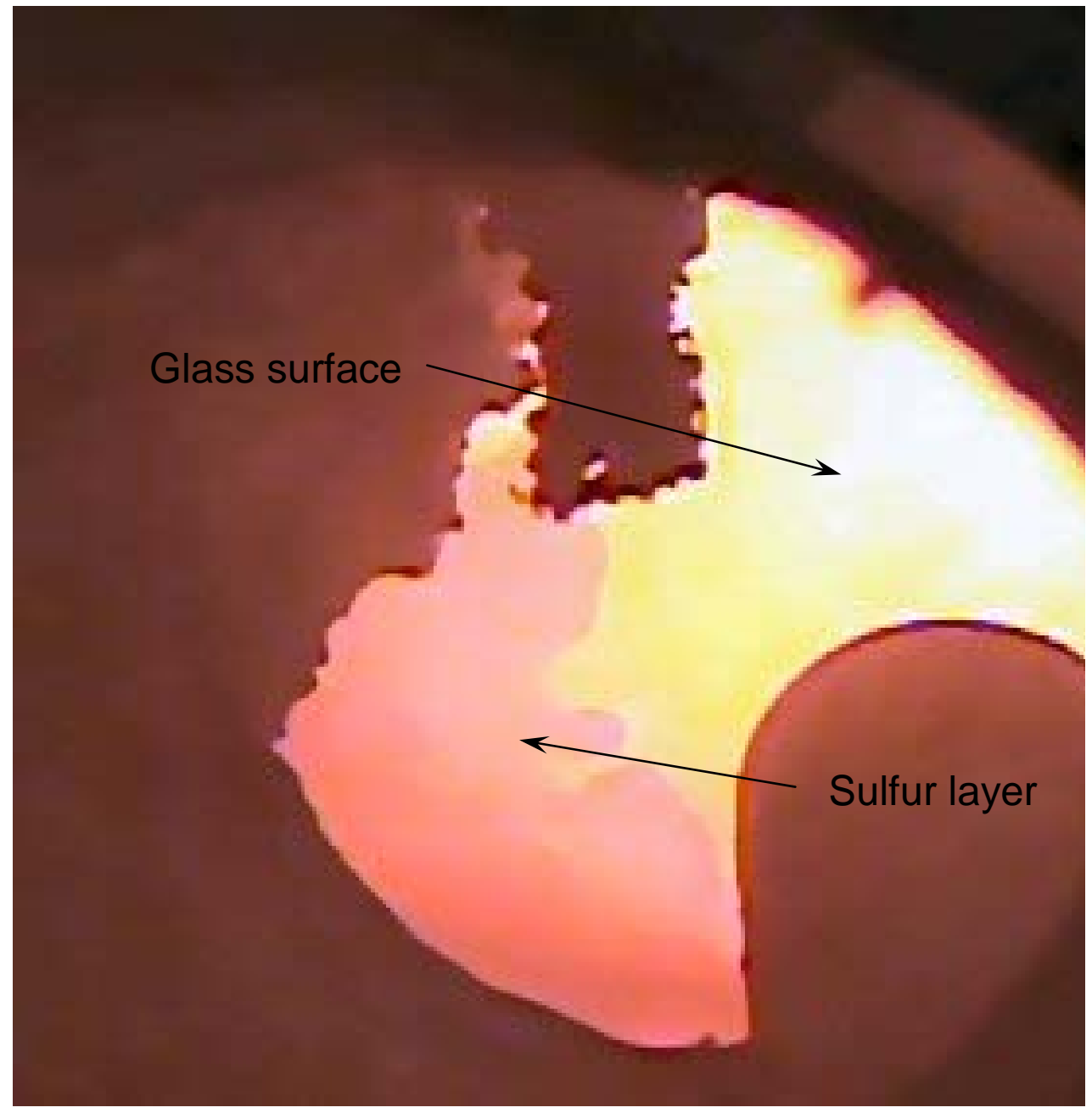

Figure 3.4. Secondary sulfur phases on the glass pool surface after LAWA DM10 Test A1B. 


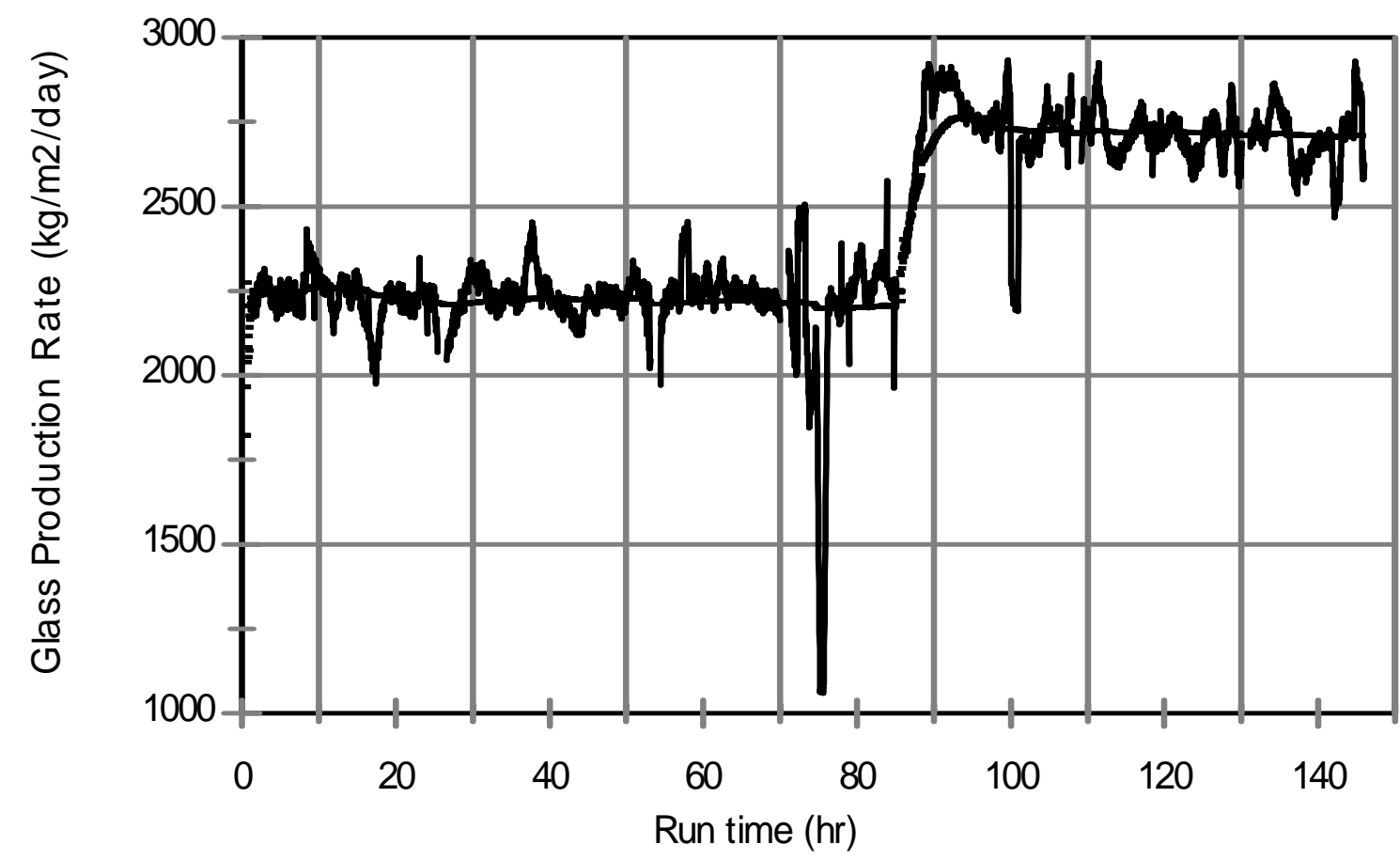

Figure 4.1.a. Glass production rates for the DM100 LAW Envelope B tests. 

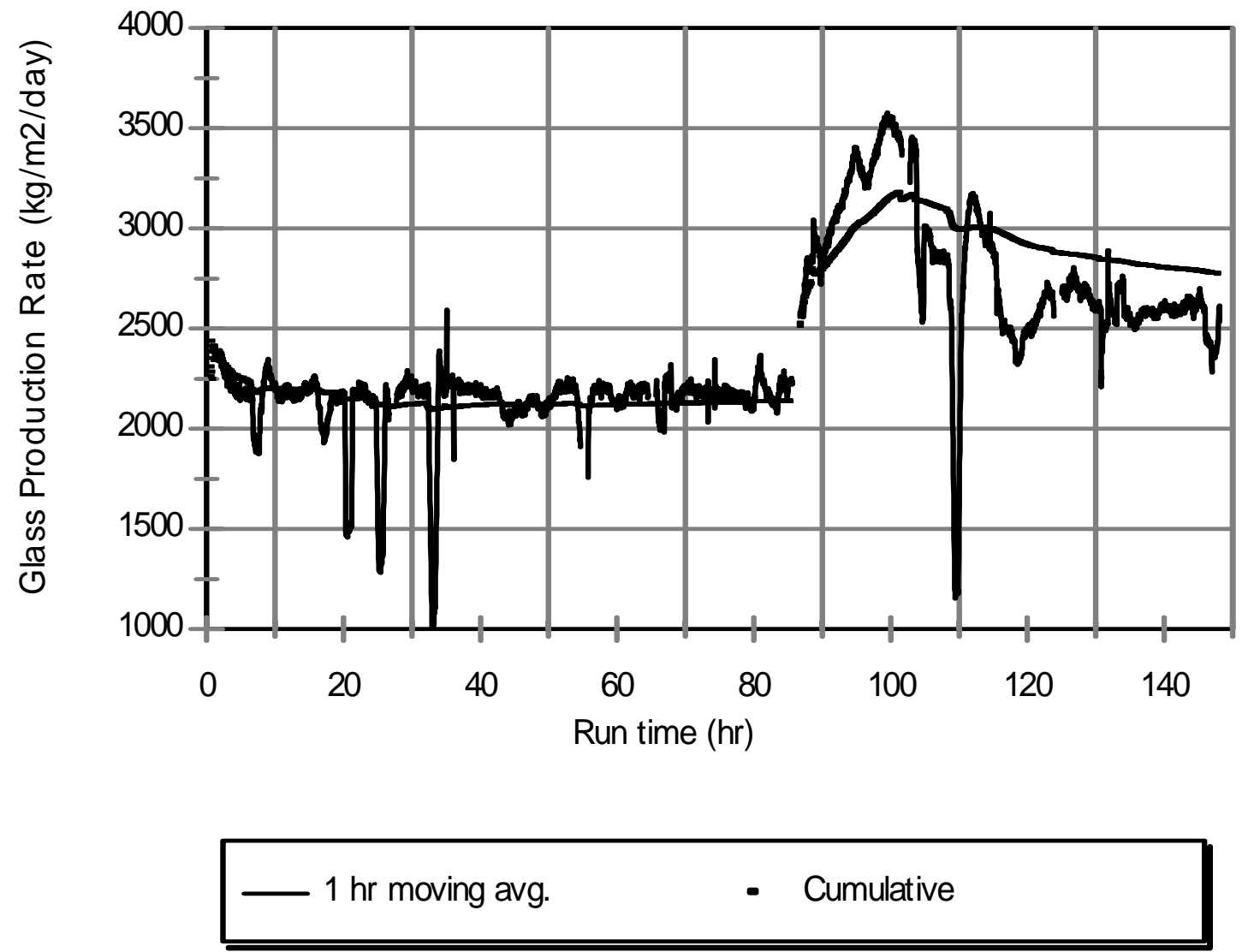

Figure 4.1.b. Glass production rates for the DM100 LAW Envelope A tests. 


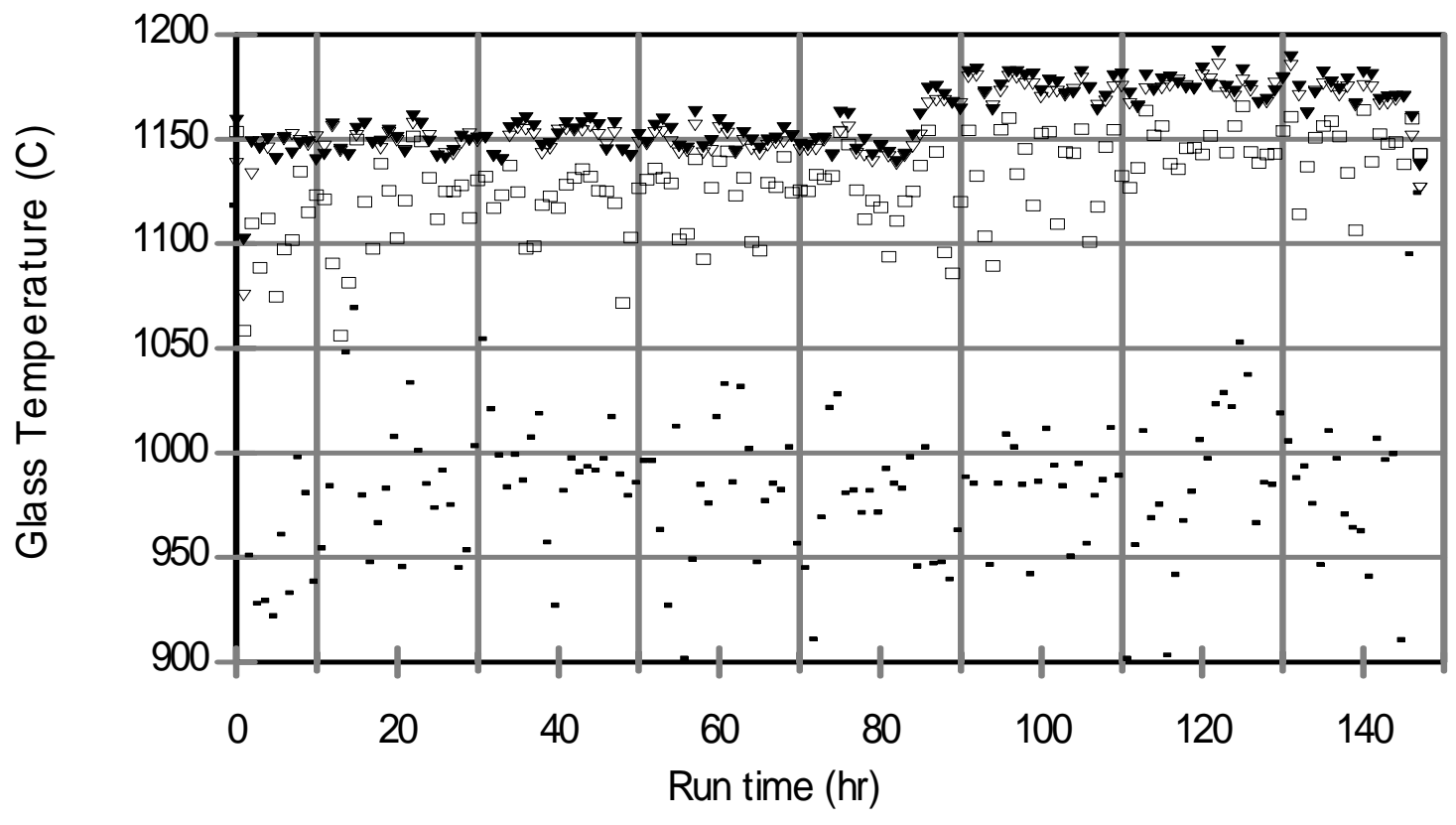

- $19^{\prime \prime}$ from floor

$\square \quad 16^{\prime \prime}$ from floor

- 10 " from floor

$\nabla \quad$ 4" from floor

Figure 4.2.a. Glass temperatures for the DM100 LAW Envelope B tests. 


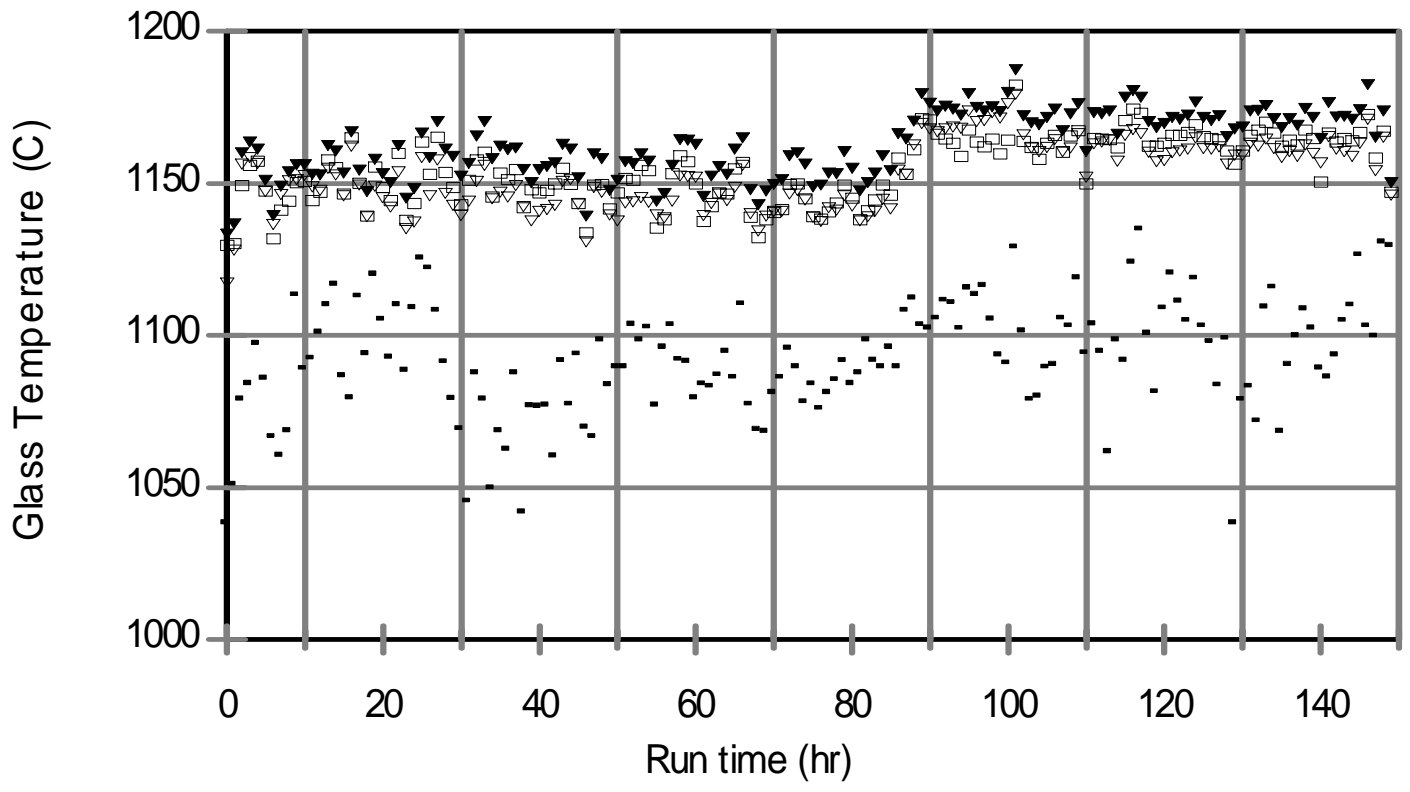
- $19^{\prime \prime}$ from floor
$\square \quad 16$ " from floor
- 10 " from floor
$\nabla \quad$ 4" from floor

Figure 4.2.b. Glass temperatures for the DM100 LAW Envelope A tests. 


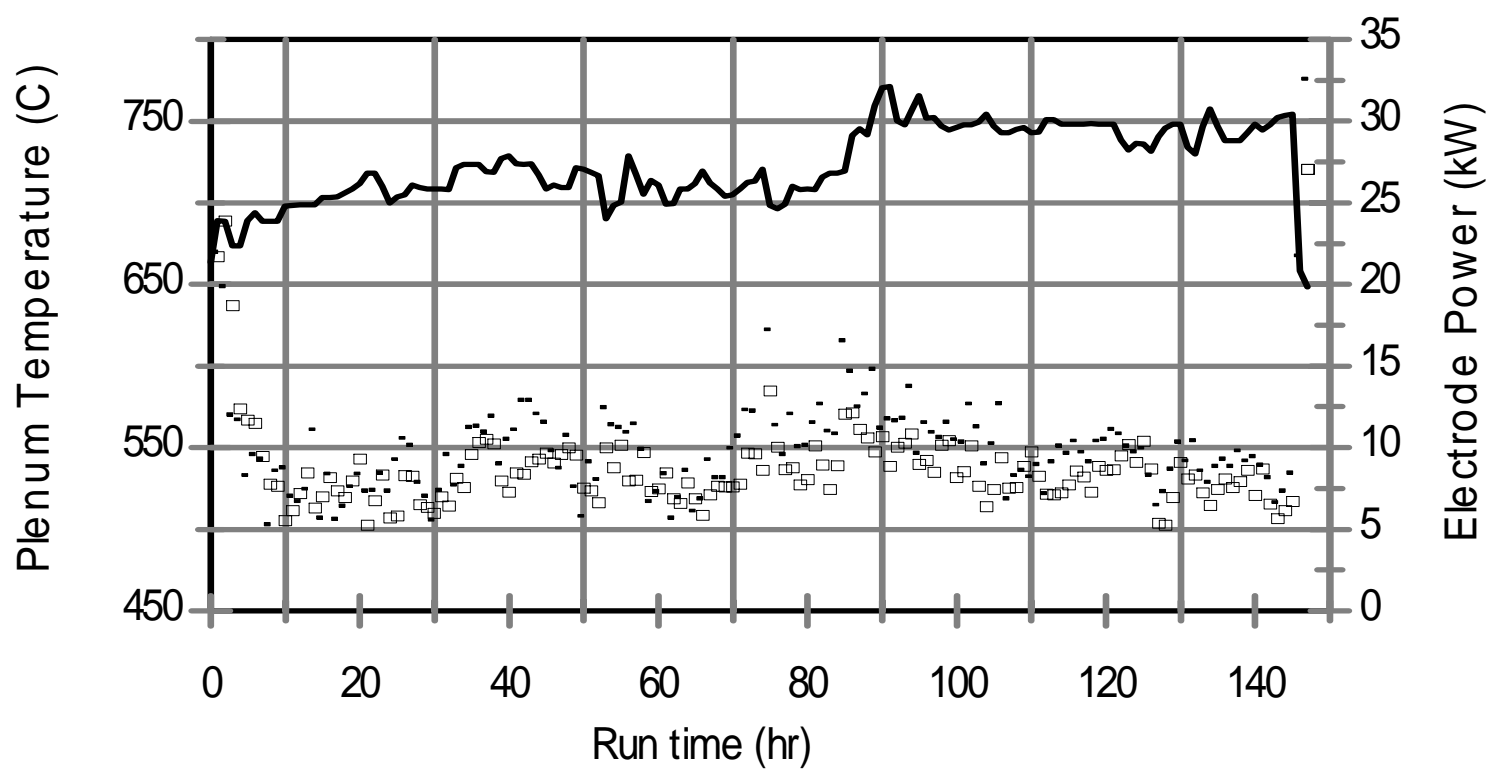

- 16 " below celing (exposed)

$\square \quad 16$ " below ceiling (thermowell)

\section{Electrode Power}

Figure 4.3.a. Plenum temperatures and electrode power for the DM100 LAW Envelope B tests. 


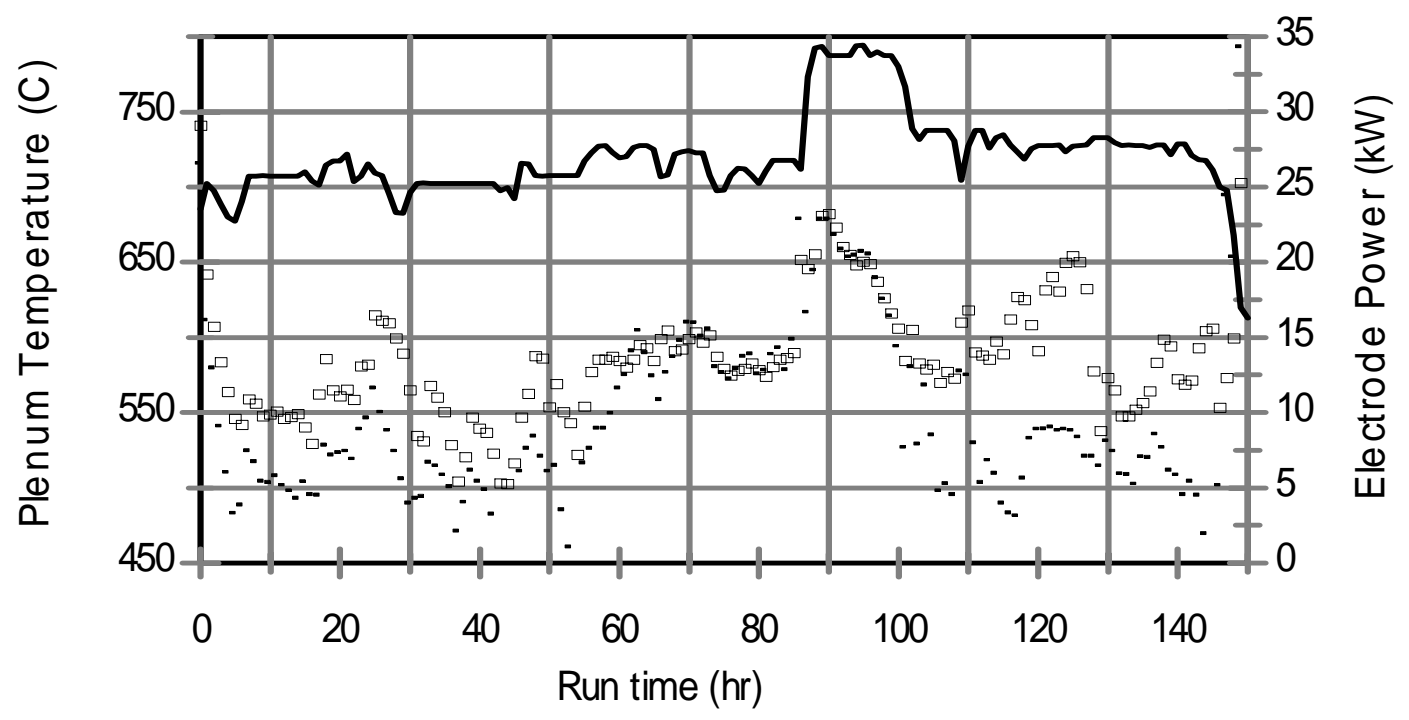

- 16" below ceiling (exposed)

$\square \quad 16$ " below ceiling (thermowell)

Electrode Power

Figure 4.3.b. Plenum temperatures and electrode power for the DM100 LAW Envelope A tests. 

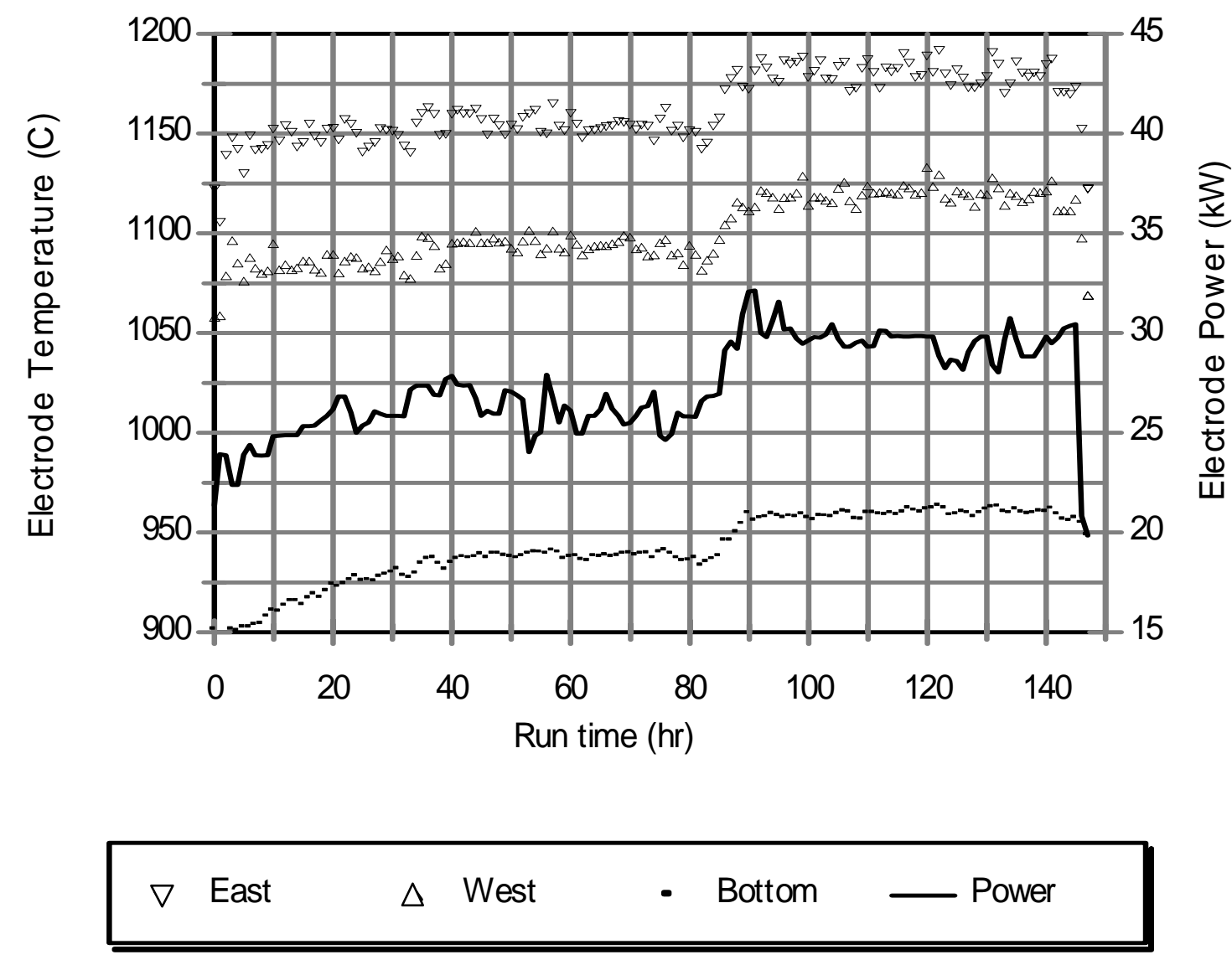

Figure 4.4.a. Electrode temperature and power for the DM100 LAW Envelope B tests. 

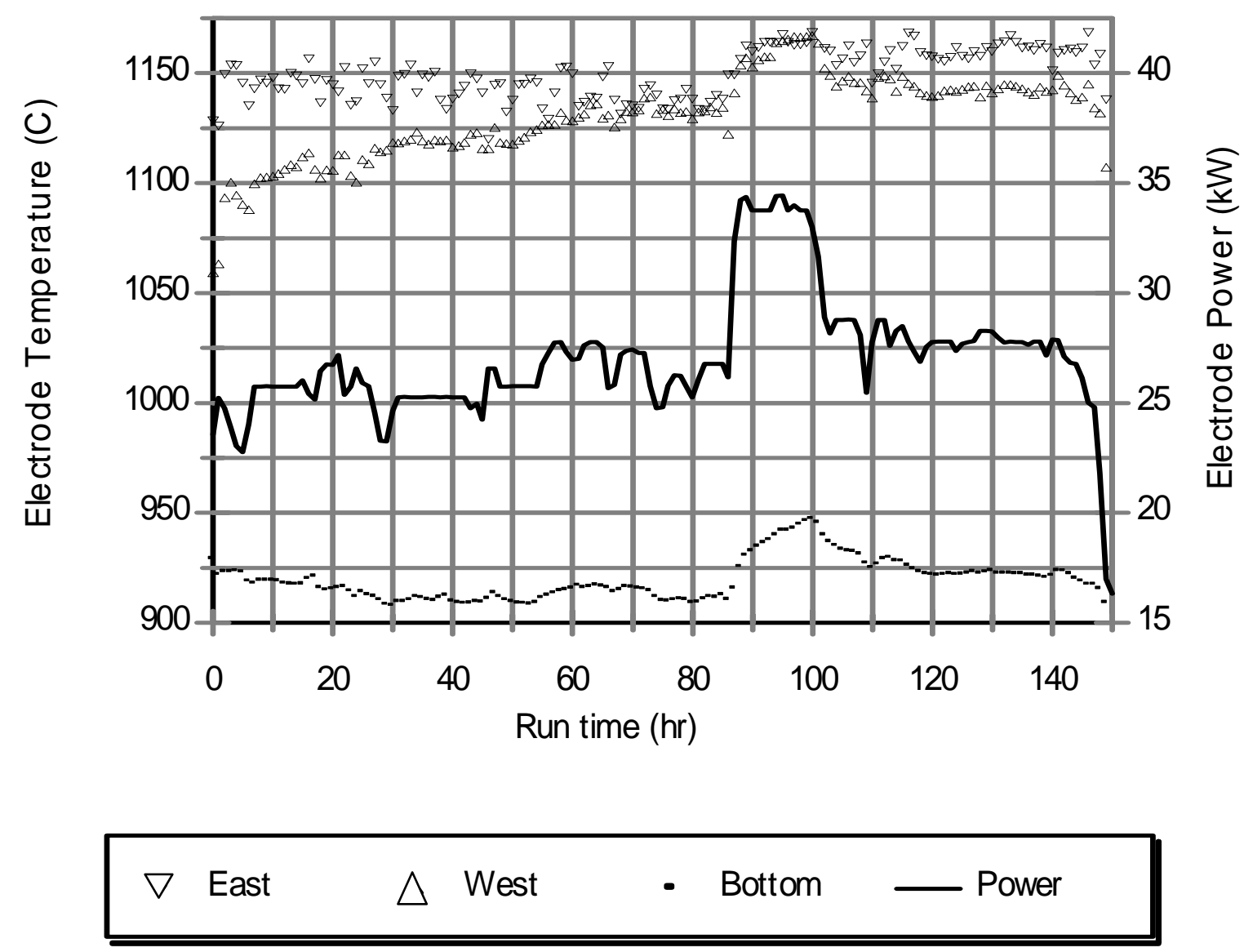

Figure 4.4.b. Electrode temperature and power for the DM100 LAW Envelope A tests. 


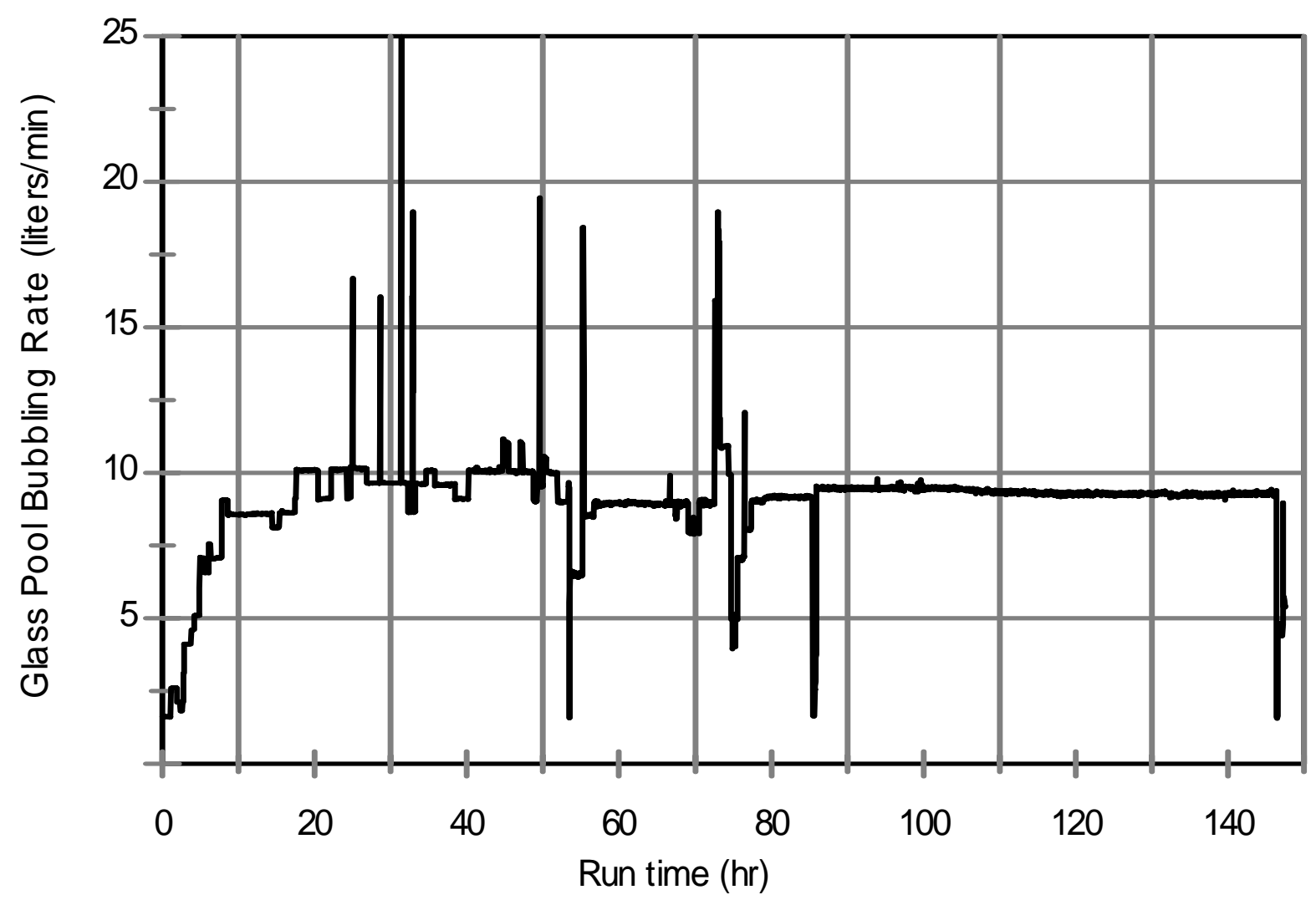

Figure 4.5.a. Glass pool bubbling rate during DM100 LAW Envelope B tests. 


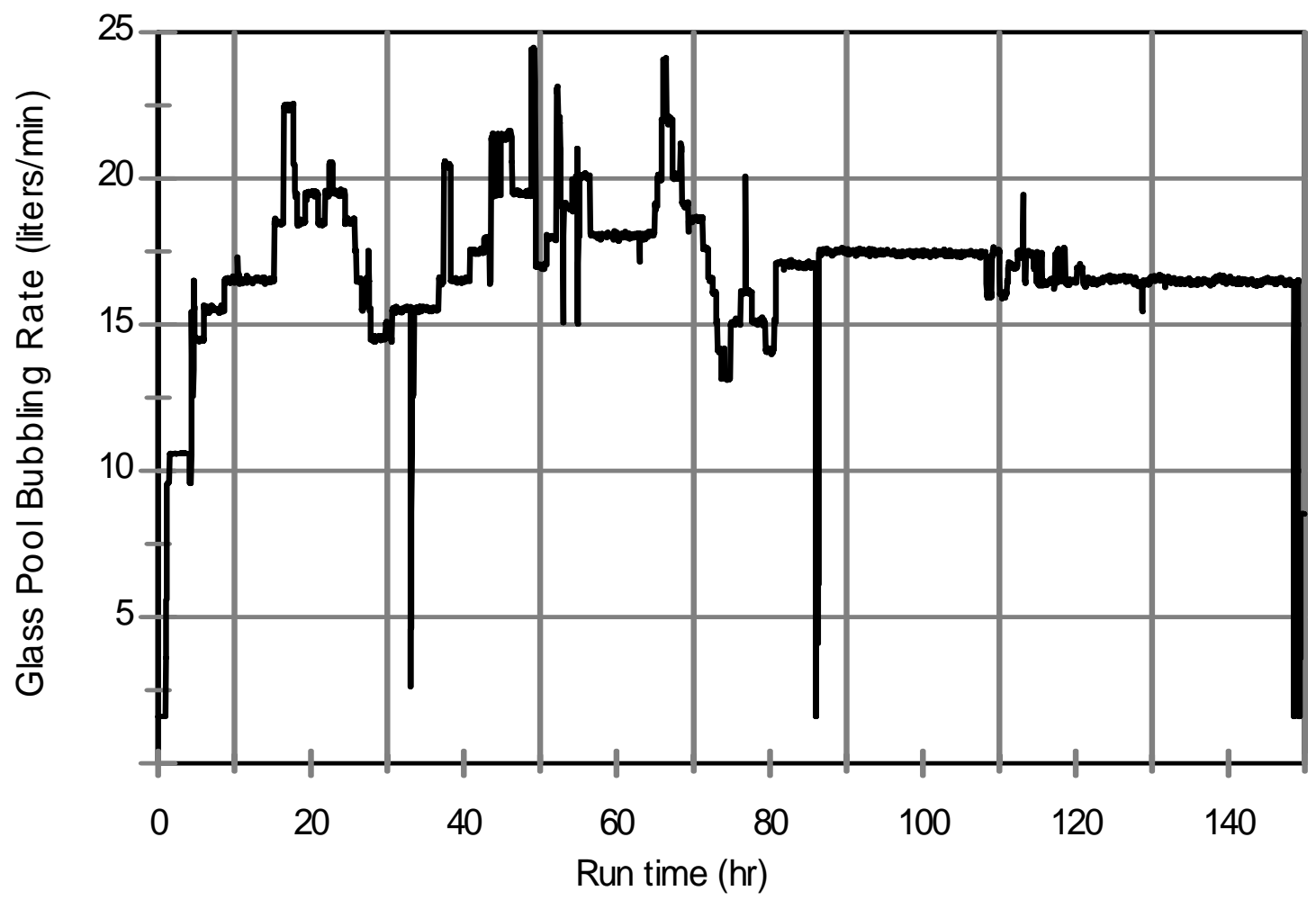

Figure 4.5.b. Glass pool bubbling rate during DM100 LAW Envelope A tests. 


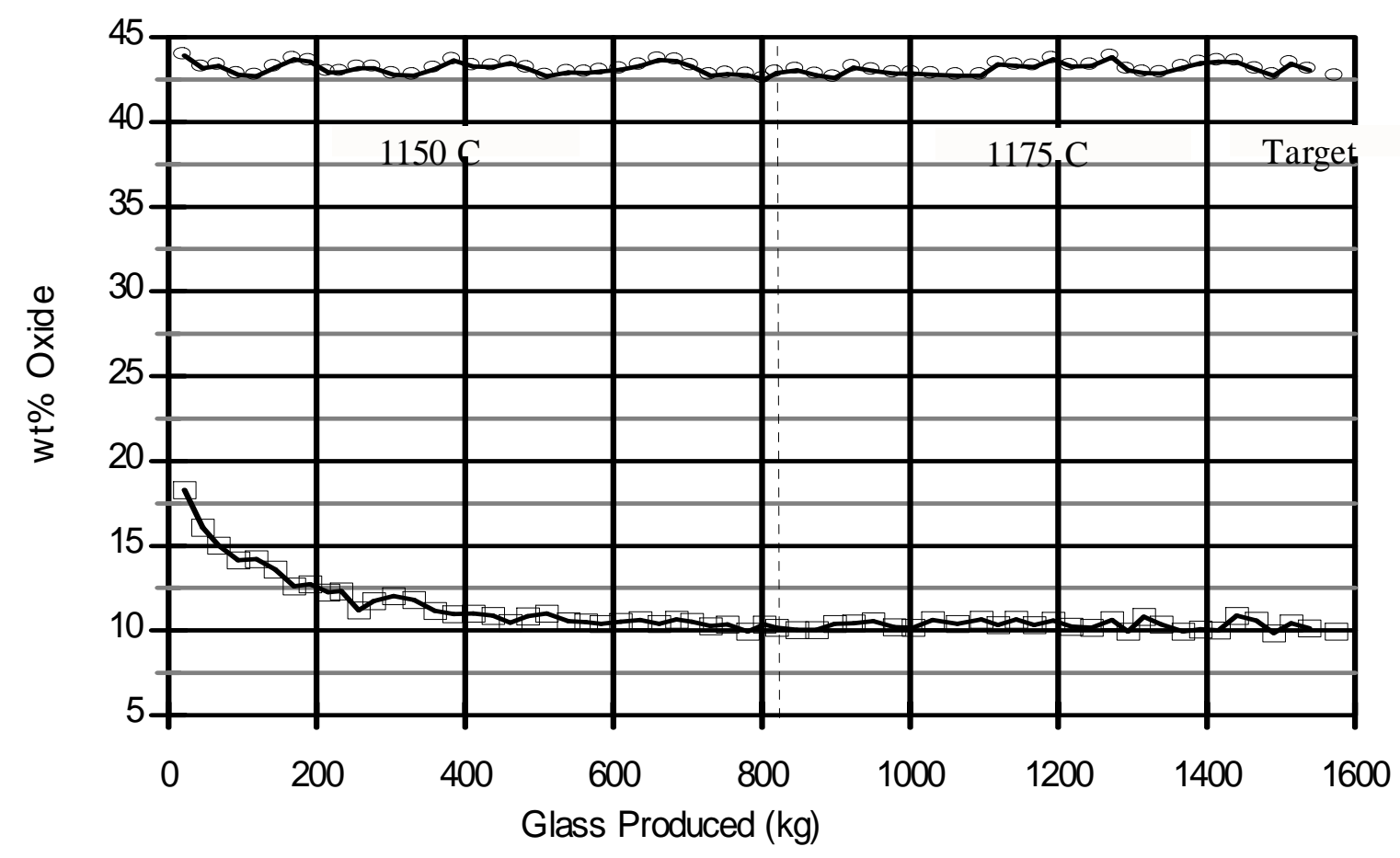

$$
\mathbb{N a} \rightarrow \mathrm{Si}
$$

Figure 5.1. XRF analysis of $\mathrm{Na}_{2} \mathrm{O}$ and $\mathrm{SiO}_{2}$ in $\mathrm{LAW}$ B DM100 product glasses. 


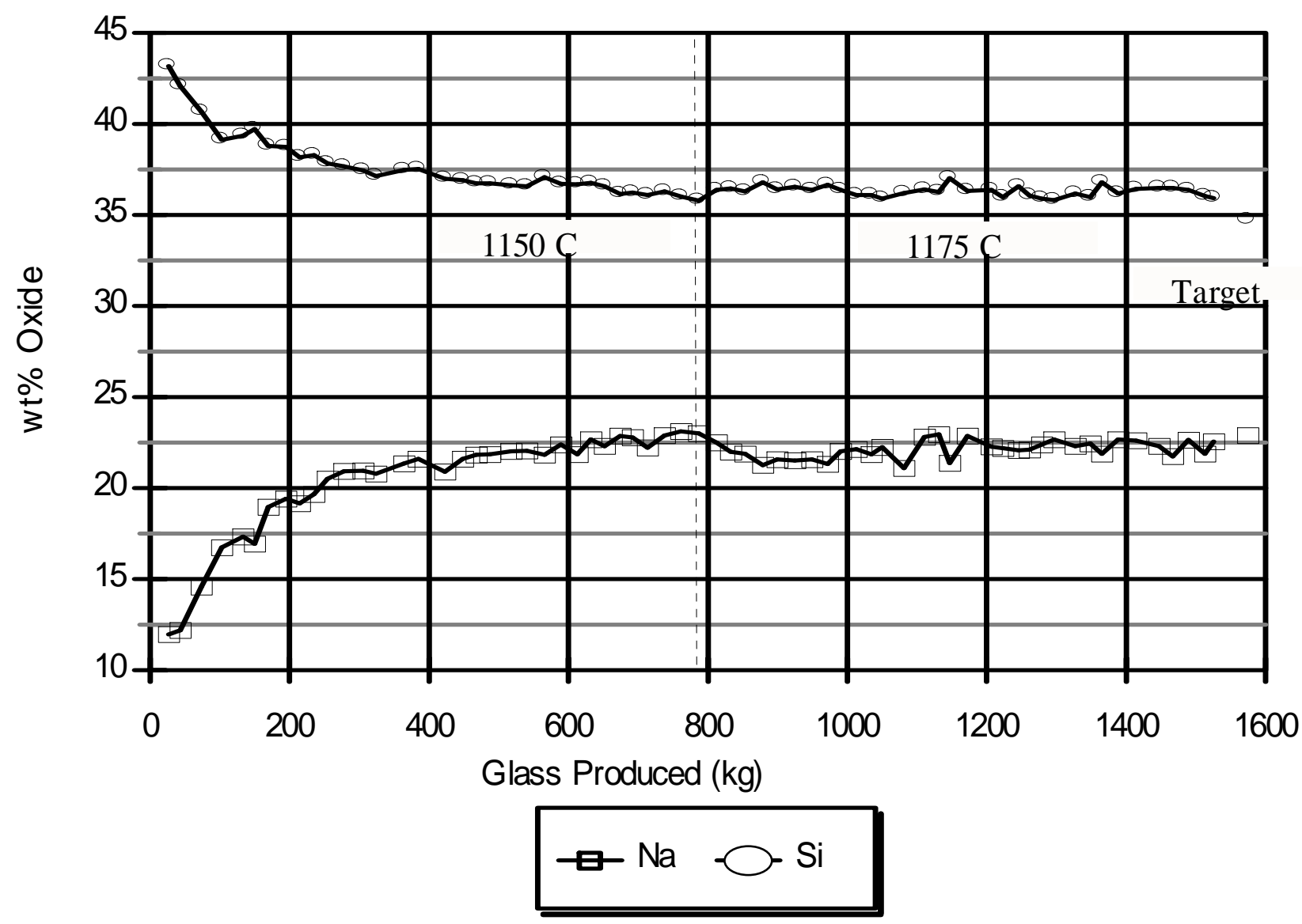

Figure 5.2. $\mathrm{XRF}$ analysis of $\mathrm{Na}_{2} \mathrm{O}$ and $\mathrm{SiO}_{2}$ in $\mathrm{LAW}$ A DM100 product glasses. 


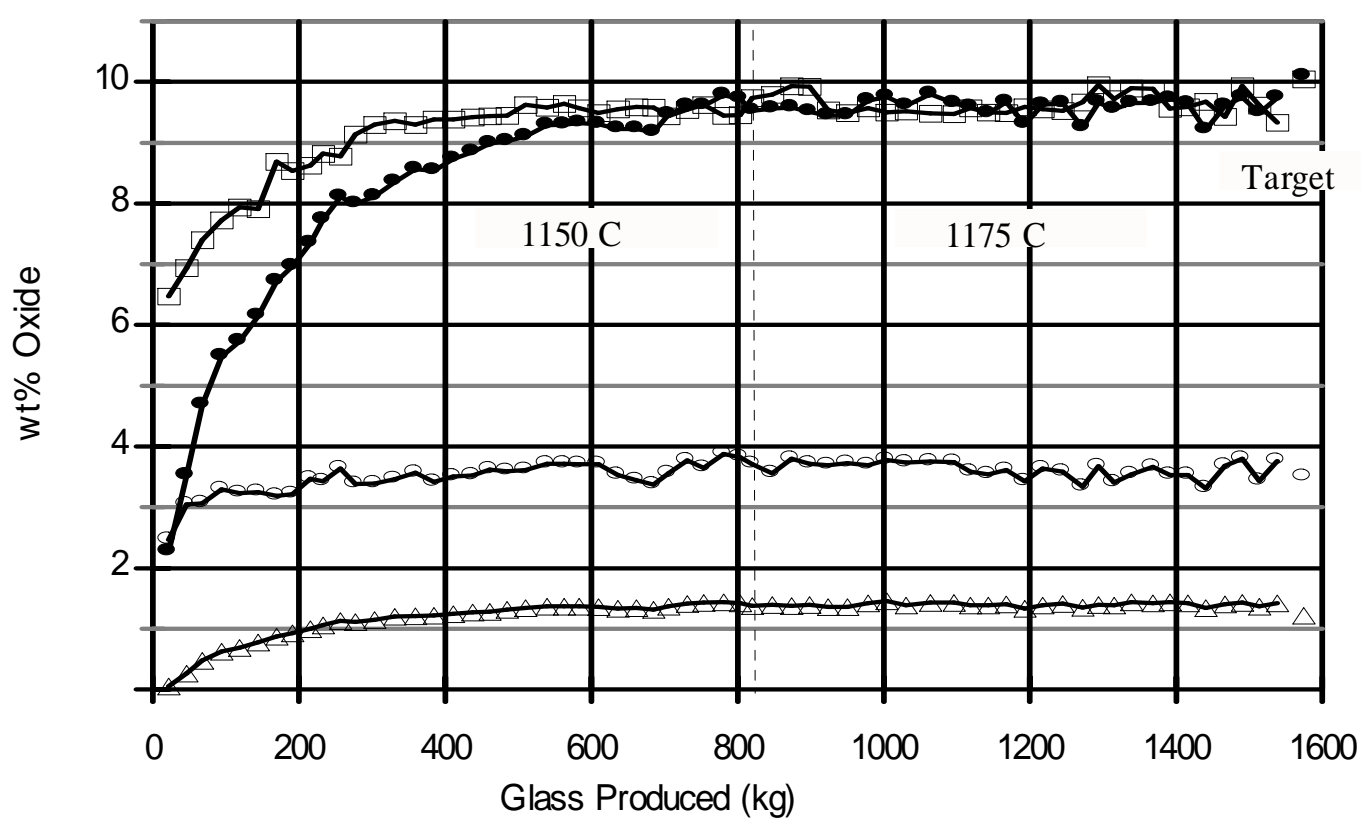

$$
\square \mathrm{Al} \rightarrow \mathrm{Ca} \rightarrow-\mathrm{V} \quad-\mathrm{Zr}
$$

Figure 5.3. XRF analysis of select major oxides in LAW B DM100 product glasses. 


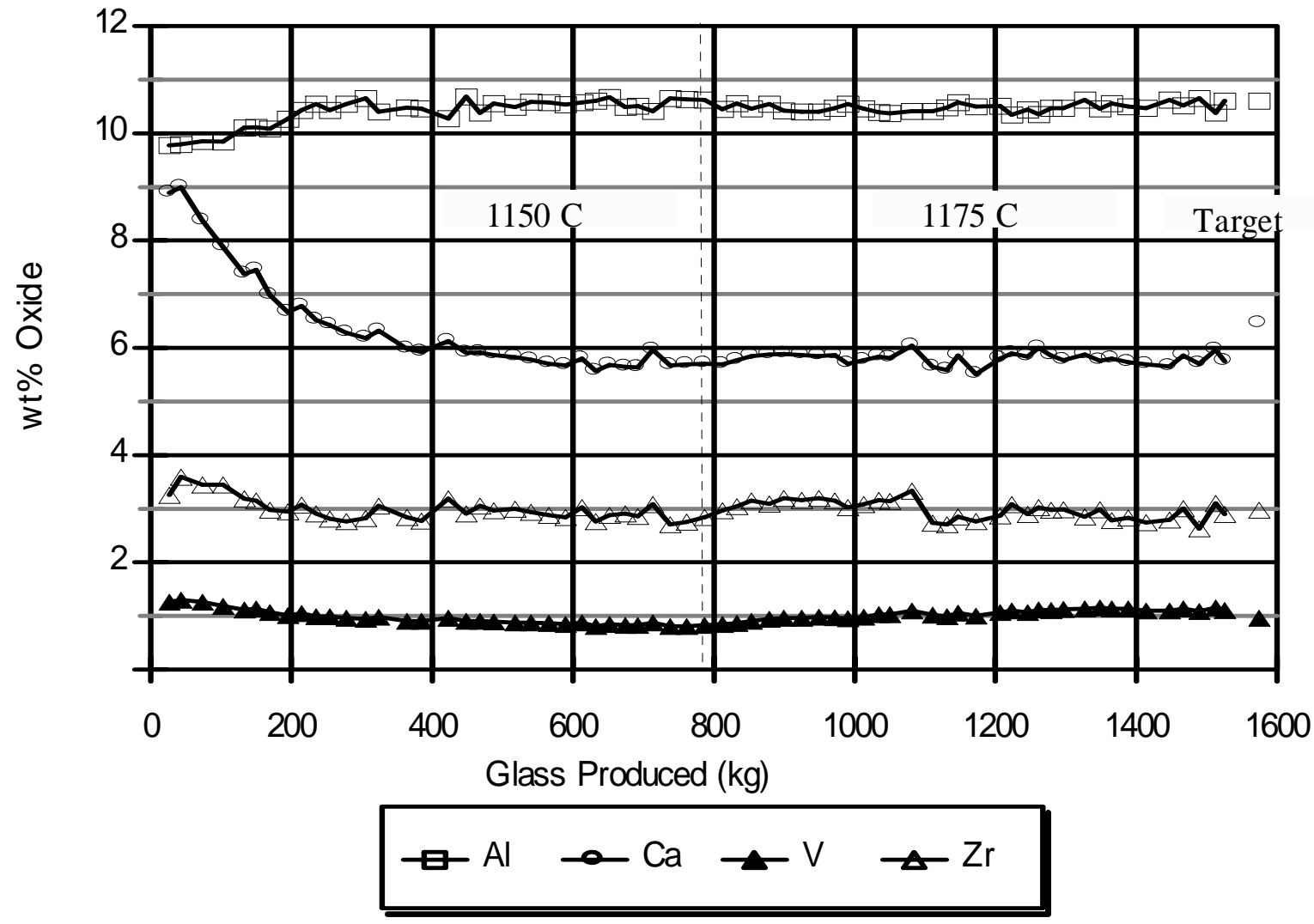

Figure 5.4. XRF analysis of select major oxides in LAW A DM100 product glasses. 


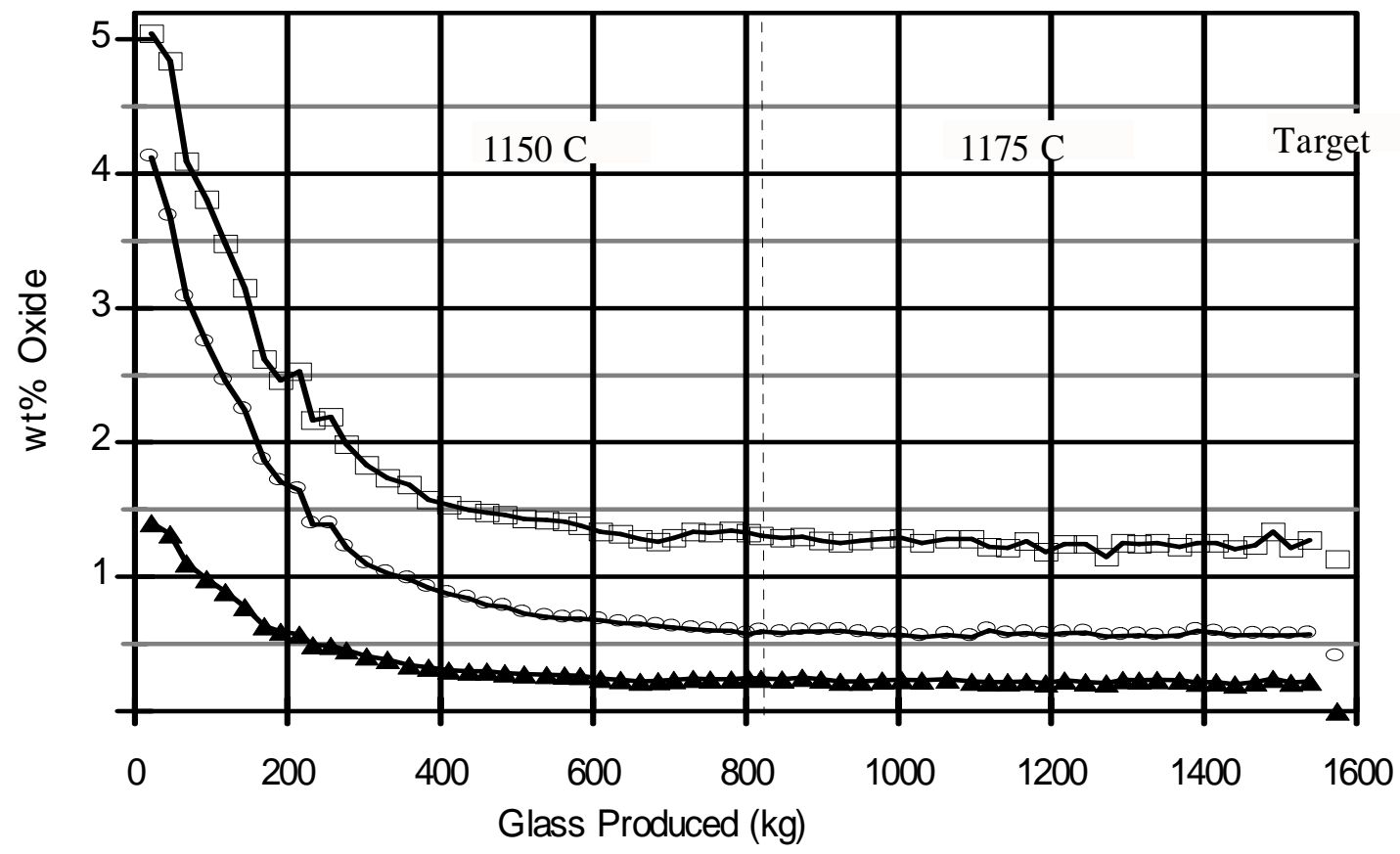

$$
\square \mathrm{Fe} \rightarrow \mathrm{K} \rightarrow \mathrm{Ti}
$$

Figure 5.5. XRF analysis of oxides in product glasses decreasing in concentration during LAW B DM100 tests. 


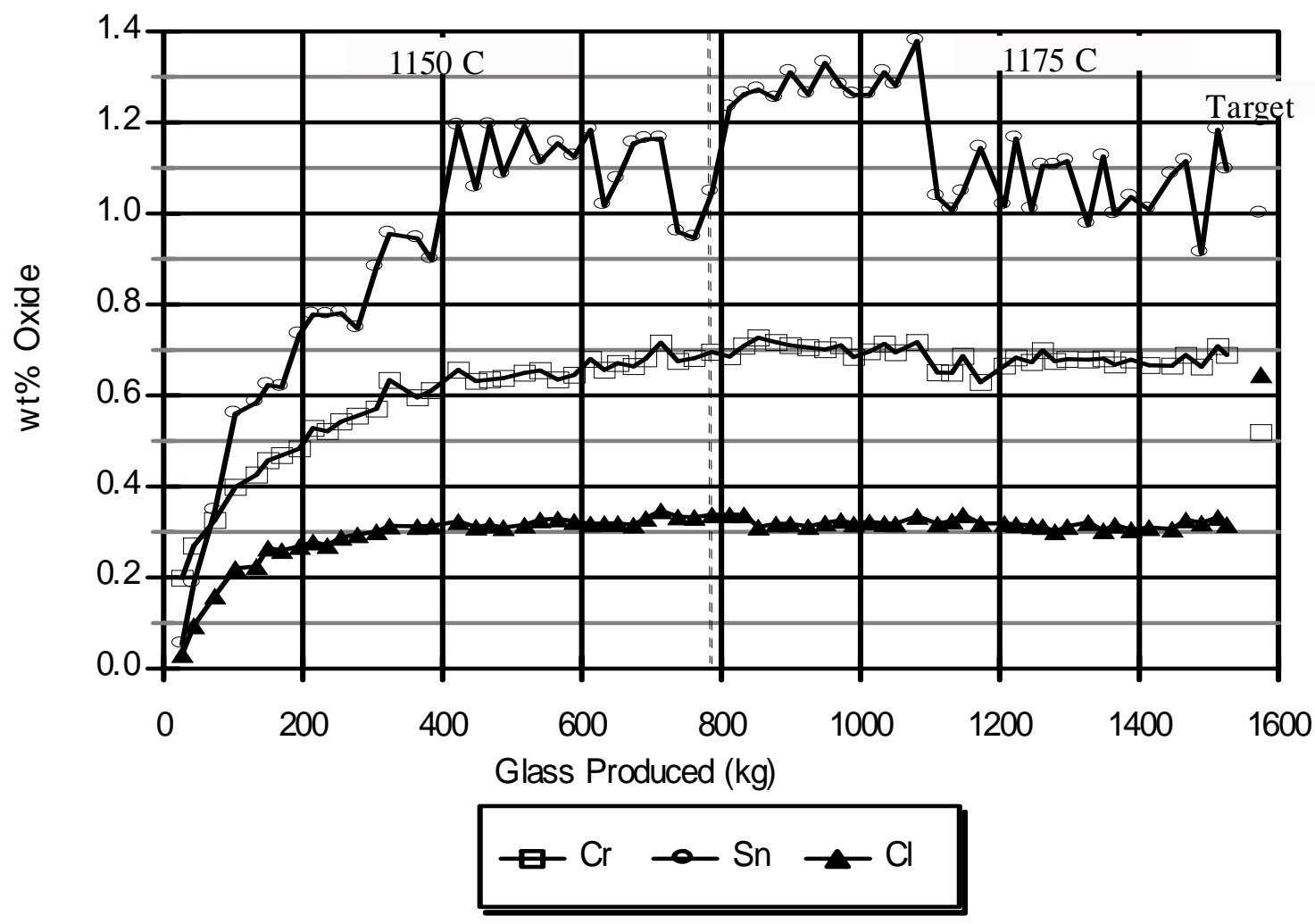

Figure 5.6. XRF analysis of oxides increasing in concentration during LAW A DM100 tests. 

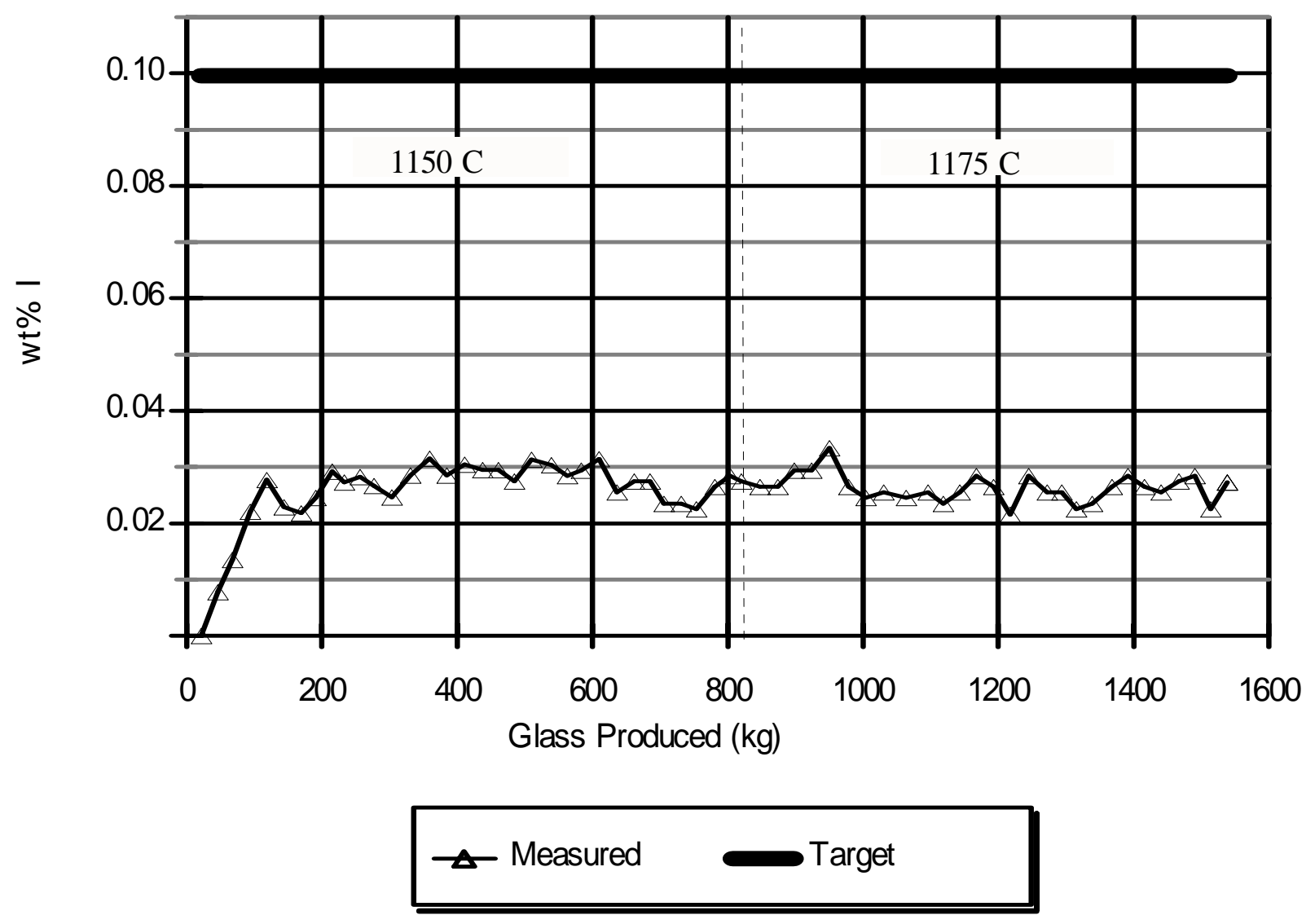

Figure 5.7. XRF analysis of iodine in LAW B DM100 product glasses. 


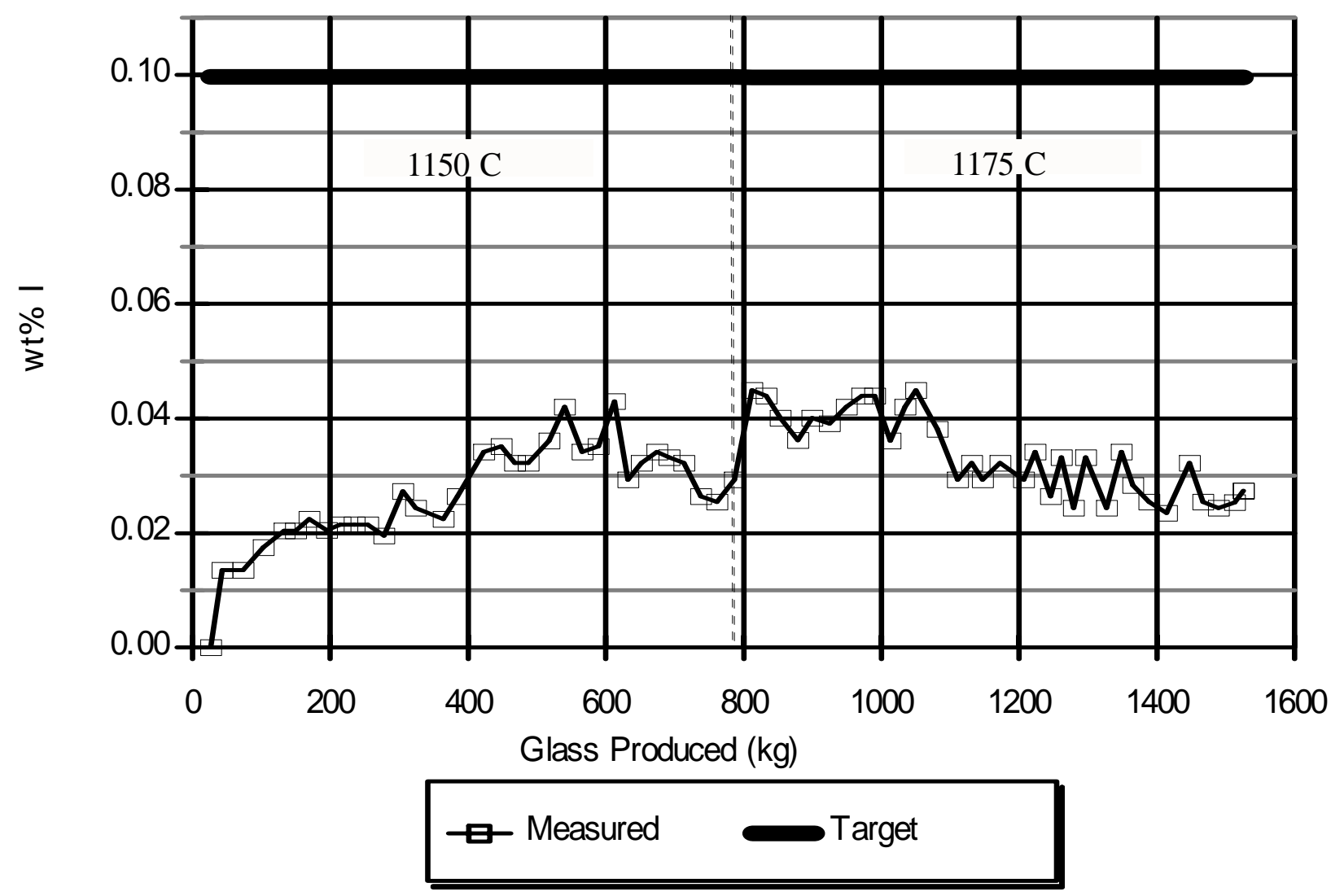

Figure 5.8. XRF analysis of iodine in LAW A DM100 product glasses. 


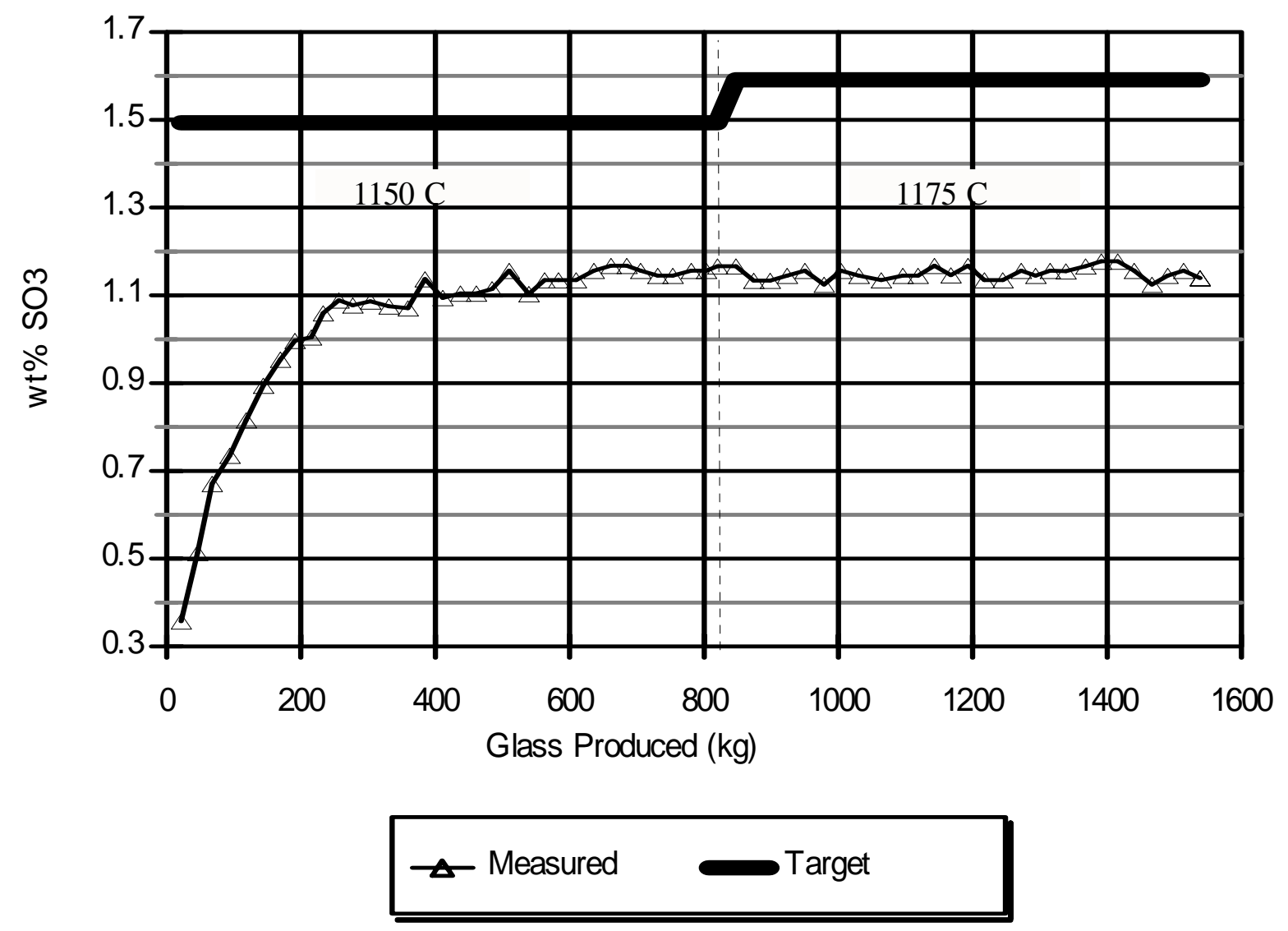

Figure 5.9. XRF analysis of sulfur in LAW B DM100 product glasses. 


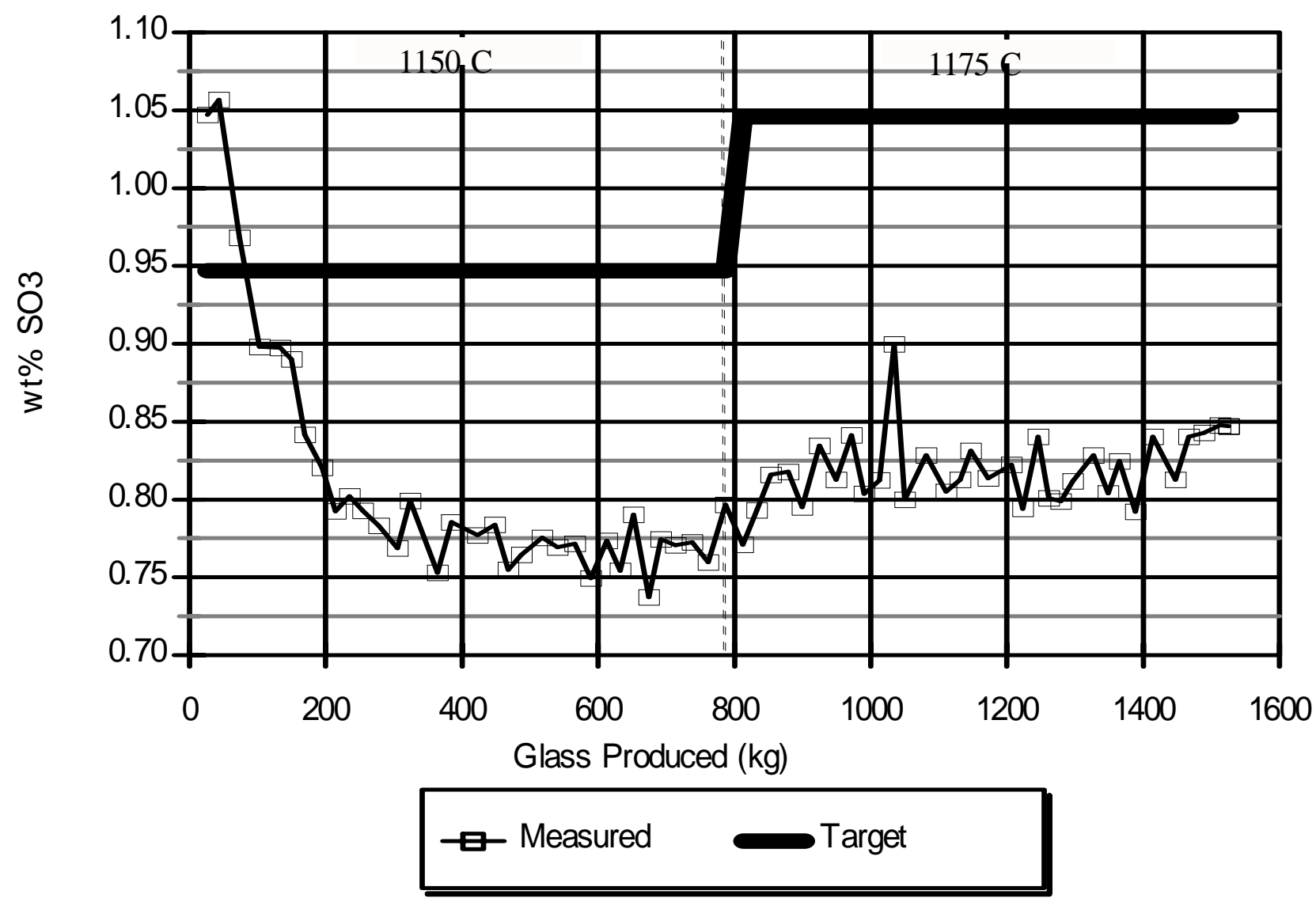

Figure 5.10. XRF analysis of sulfur in LAW A DM100 product glasses. 


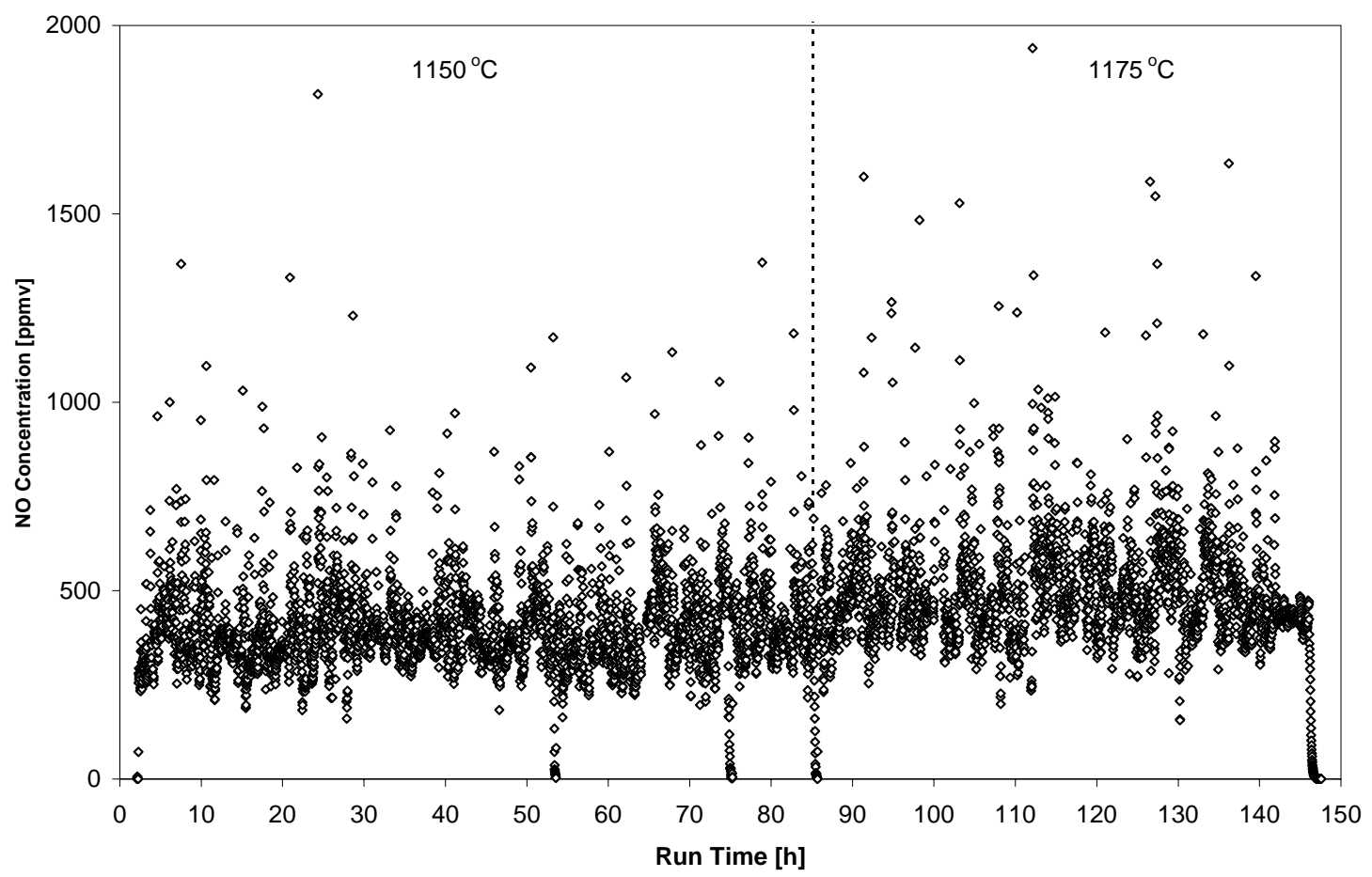

Figure 6.1.a. Nitrogen oxide concentrations in off-gas from FTIR for the DM100 LAW Envelope B tests. 


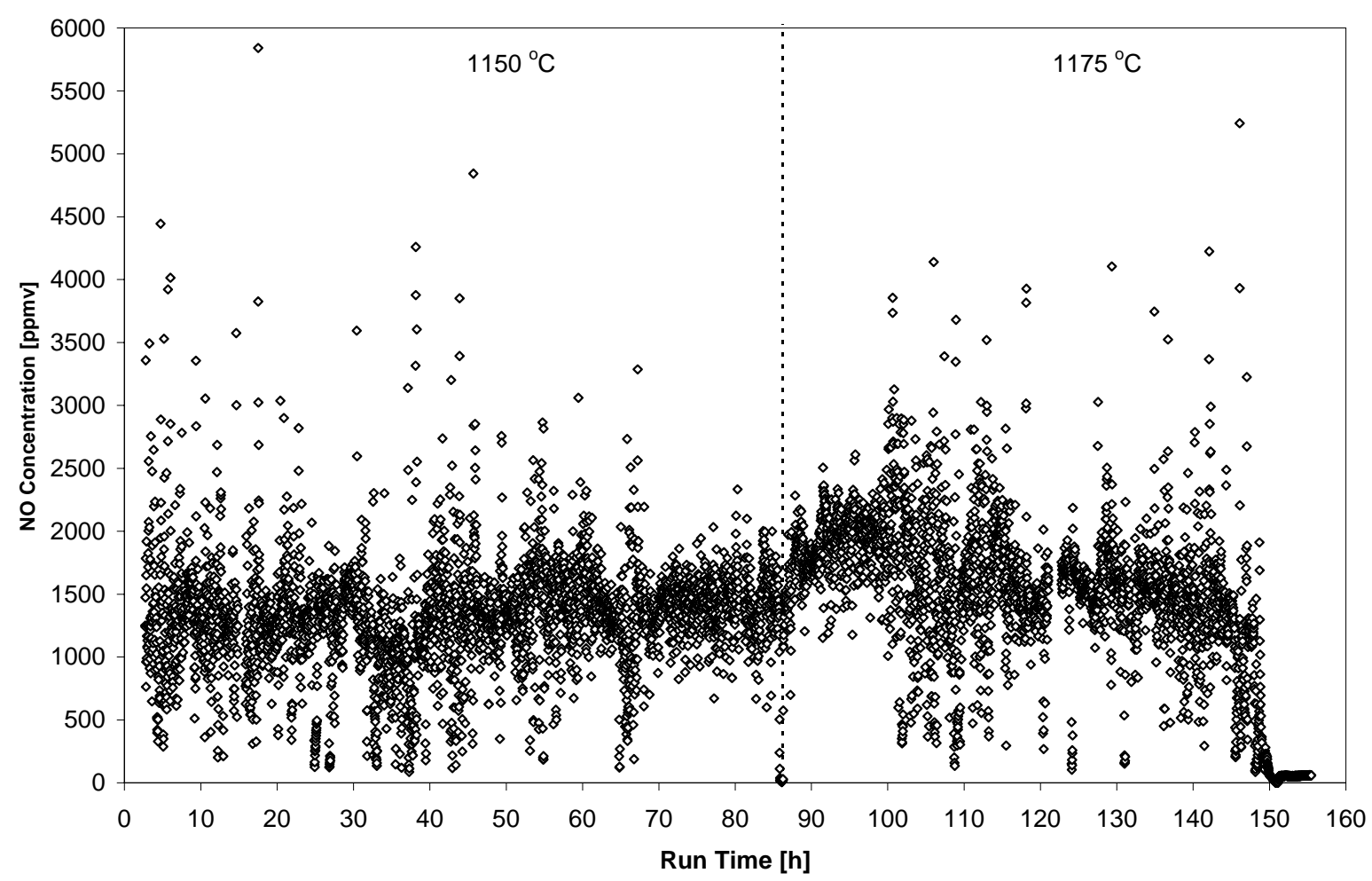

Figure 6.1.b. Nitrogen oxide concentrations in off-gas from FTIR for the DM100 LAW Envelope A tests. 


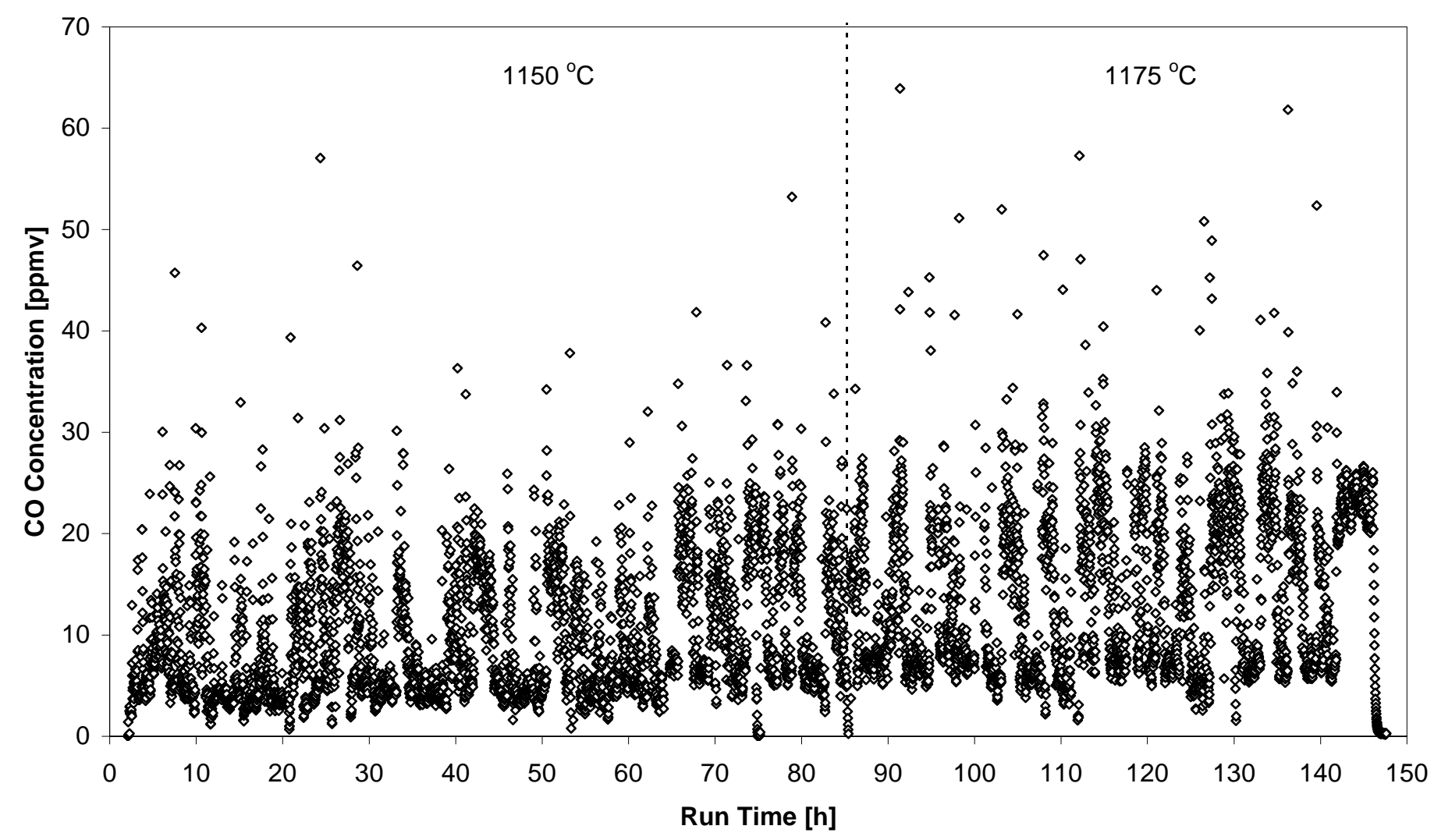

Figure 6.2.a. CO concentrations in off-gas from FTIR for the DM100 LAW Envelope B tests. 


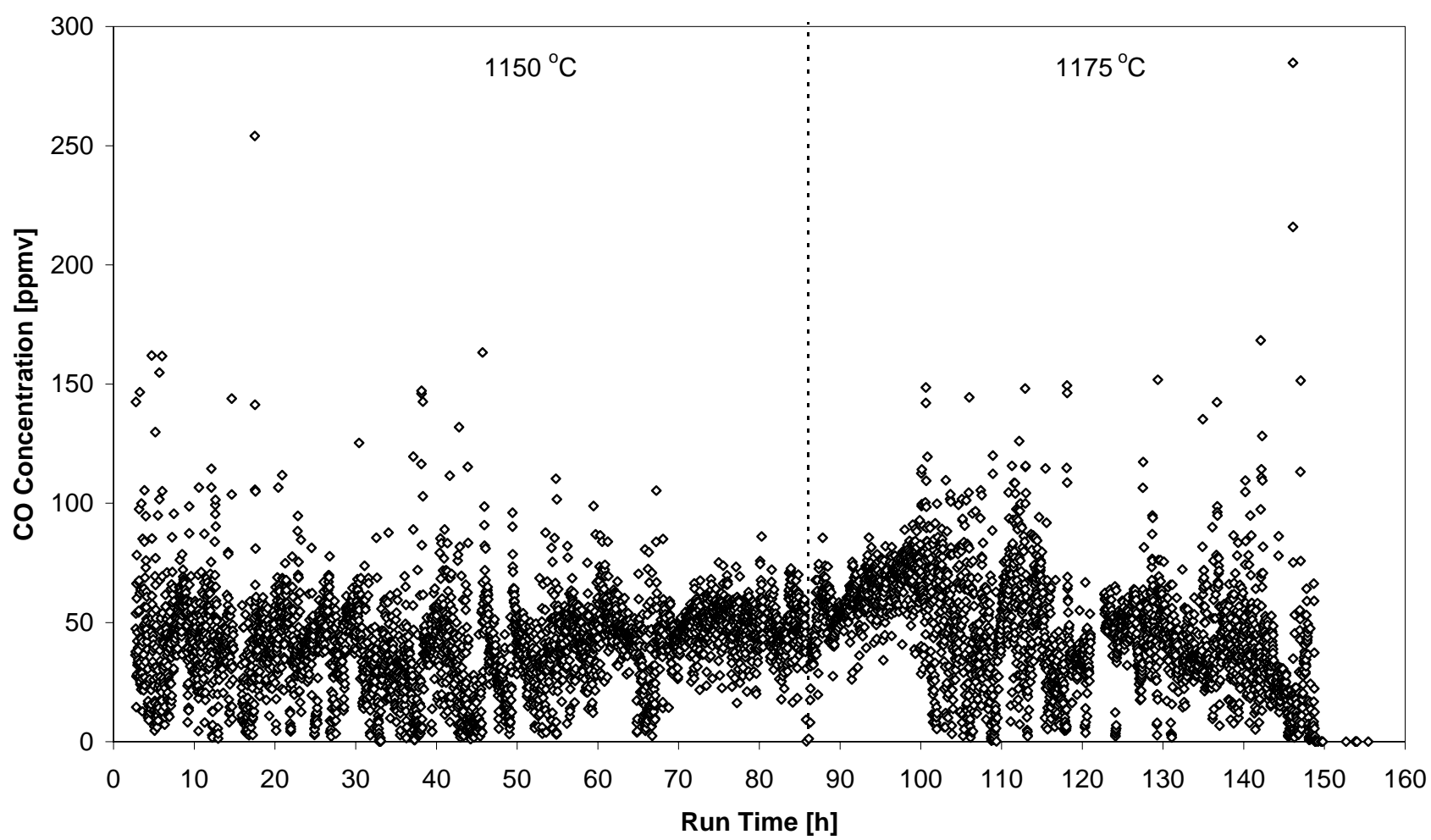

Figure 6.2.b. CO concentrations in off-gas from FTIR for the DM100 LAW Envelope A tests. 


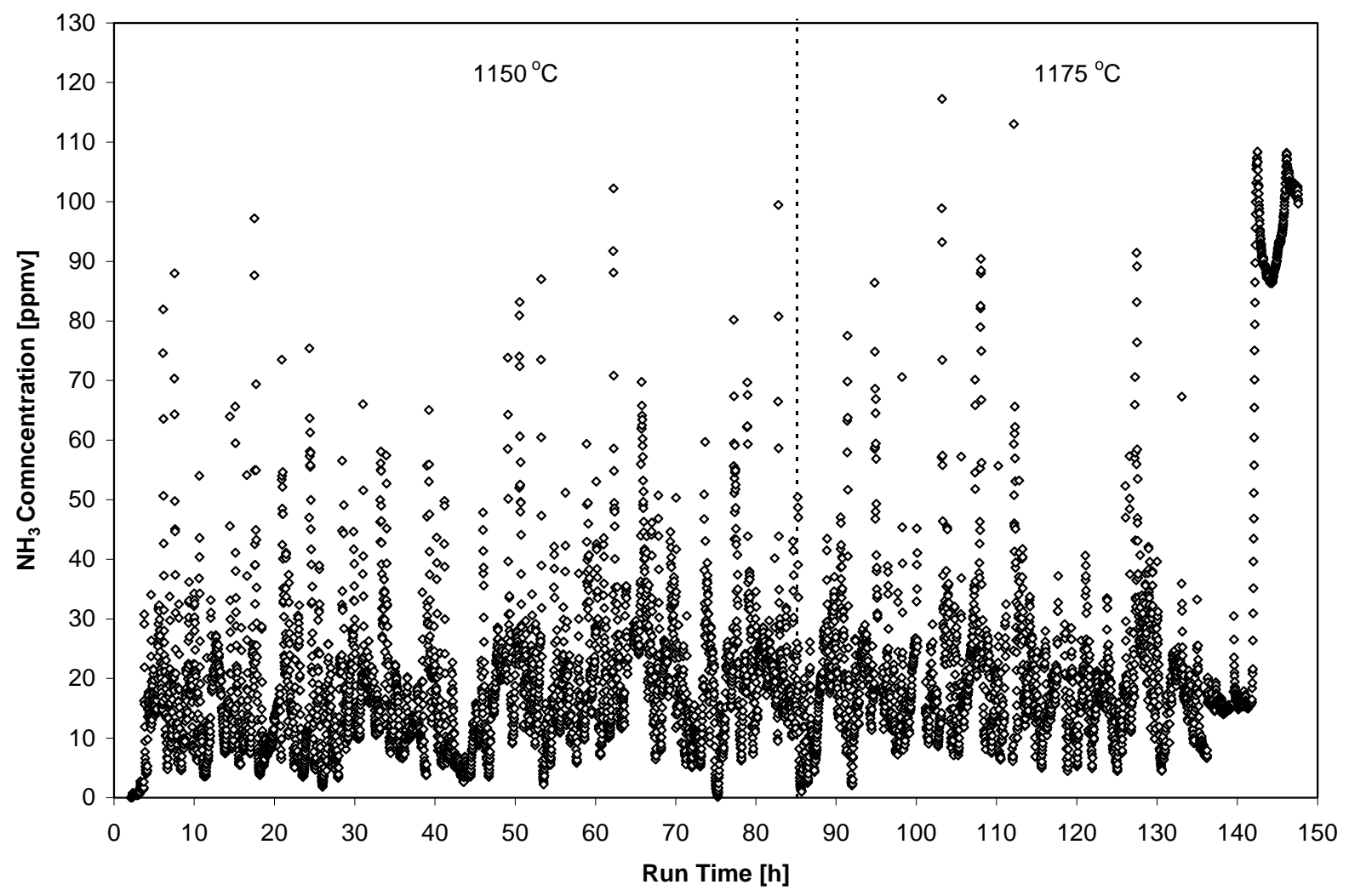

Figure 6.3.a. $\mathrm{NH}_{3}$ concentrations in off-gas from FTIR for the DM100 LAW Envelope B tests. 


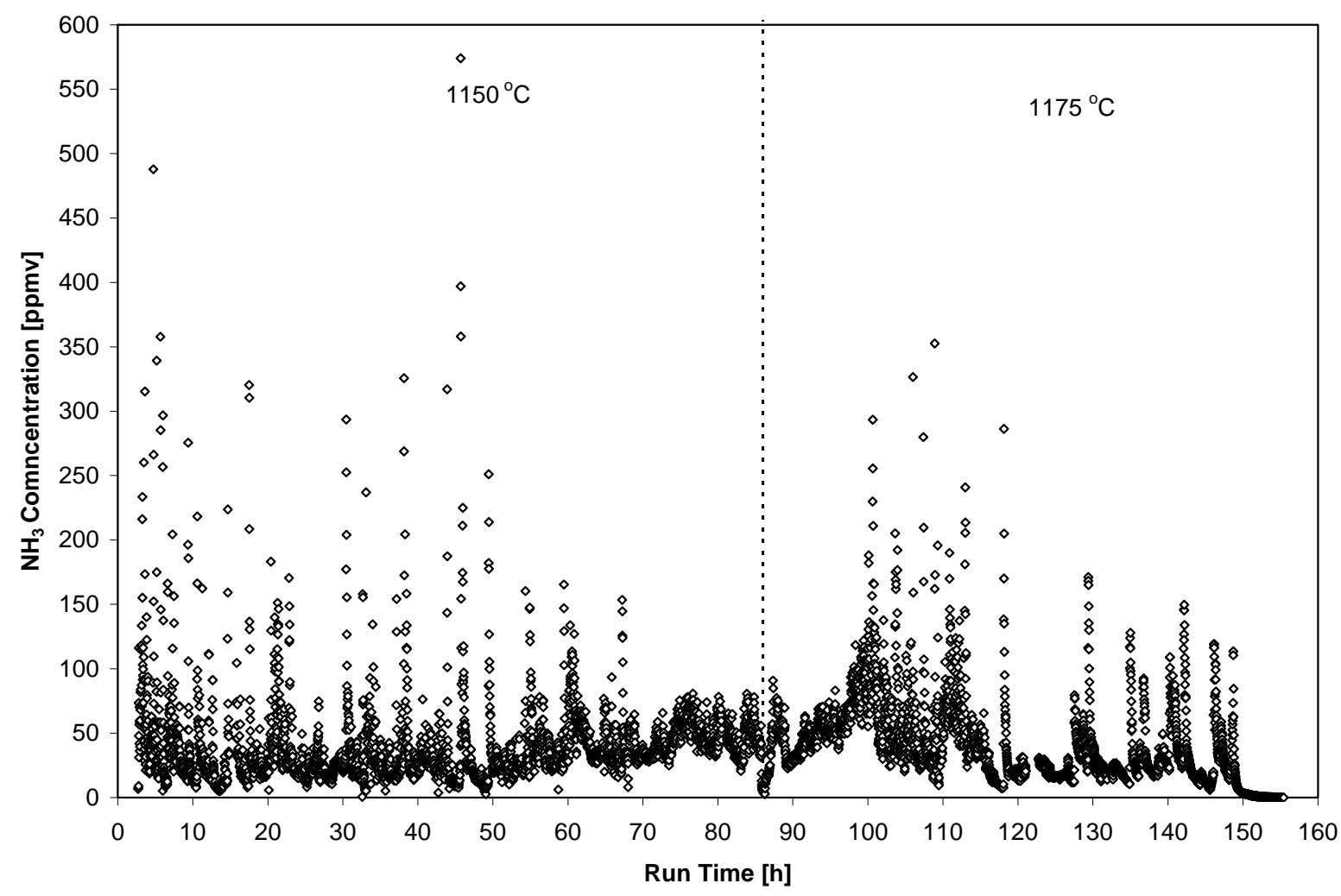

Figure 6.3.b. $\mathrm{NH}_{3}$ concentrations in off-gas from FTIR for the DM100 LAW Envelope A tests. 


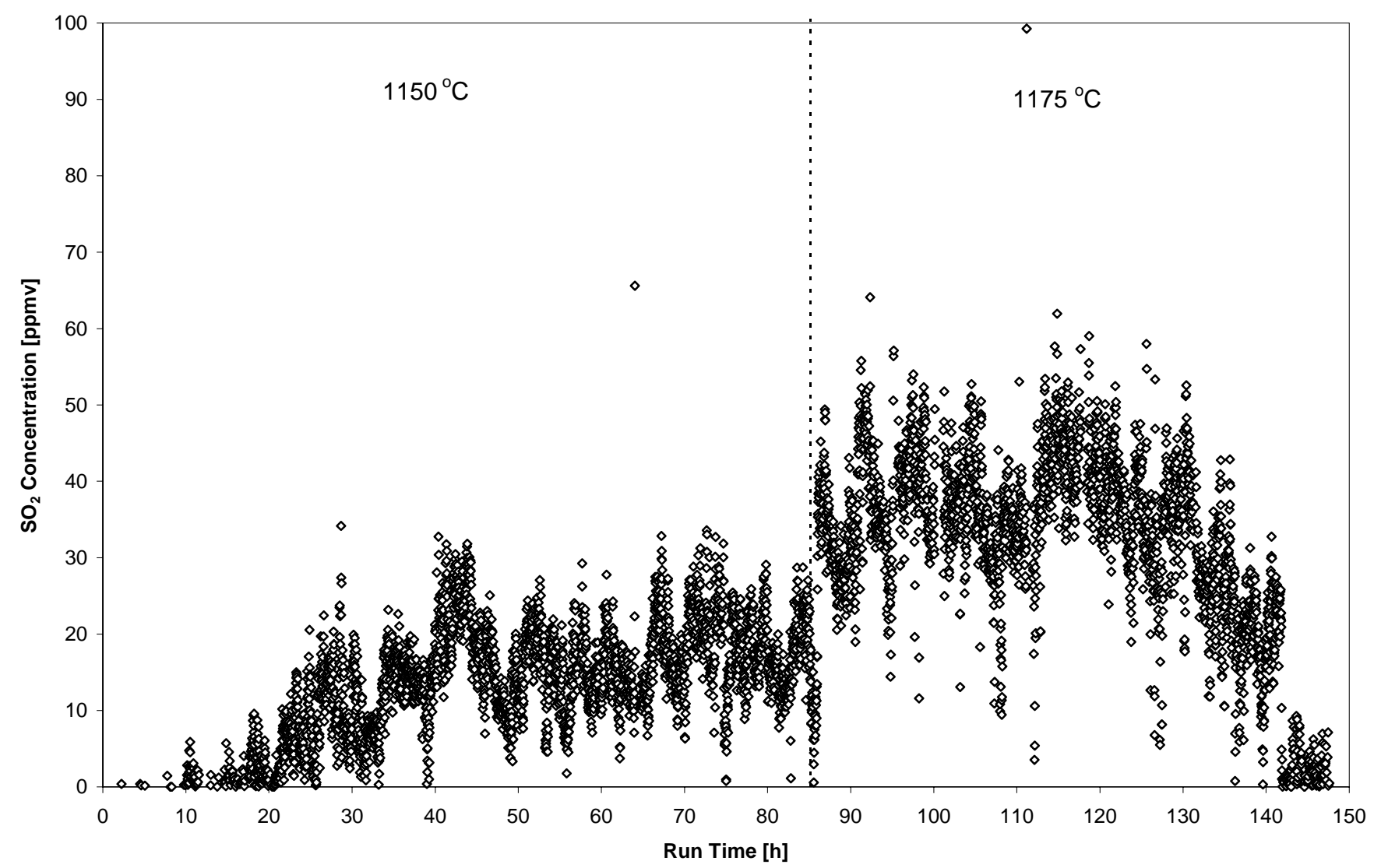

Figure 6.4. $\mathrm{SO}_{2}$ concentrations in off-gas from FTIR for the DM100 LAW Envelope B tests. 